$$
\text { UNIVERSIDADE DE SÃO PAULO }
$$

ESCOLA DE COMUNICAÇÕES E ARTES - ECA

Juliana Harrison Henno

A cor como fonte luminosa e a inserção do receptor 
Juliana Harrison Henno

A cor como fonte luminosa e a inserção do receptor

Dissertação apresentada ao Programa de Pós-Graduação em Artes Visuais, Área de Concentração Poéticas Visuais, na Linha de Pesquisa Multimeios, da Escola de Comunicações e Artes da Universidade de São Paulo, como exigência parcial para obtenção do Título de Mestre em Artes Visuais, sob a orientação da $\operatorname{Prof}^{\mathrm{a}}$. Dr ${ }^{\mathrm{a}}$. Monica Baptista Sampaio Tavares.

São Paulo 
Autorizo a reprodução e divulgação total ou parcial deste trabalho, por qualquer meio convencional ou eletrônico, para fins de estudo e pesquisa desde que citada a fonte.

Henno, Juliana Harrison

A cor como fonte luminosa e a inserção do receptor / Juliana Harrison Henno. - - São Paulo : J. H. Henno, 2010.

$221 \mathrm{p}$.

Dissertação (Mestrado) - Escola de Comunicações e Artes/ Universidade de São Paulo.

Orientadora: Profa. Dra. Monica Baptista Sampaio Tavares

1. Arte digital 2. Cor 3. Fonte luminosa 4. Luz 5. Tecnologia 6. Participação I. Tavares, Monica Baptista Sampaio II. Título. 
Juliana Harrison Henno

A cor como fonte luminosa e a inserção do receptor

Dissertação apresentada ao Programa de Pós-Graduação em Artes Visuais, Área de Concentração Poéticas Visuais, na Linha de Pesquisa Multimeios, da Escola de Comunicações e Artes da Universidade de São Paulo, como exigência parcial para obtenção do Título de Mestre em Artes Visuais.

Aprovada em ___ $/ 2010$

Banca Examinadora: 
a Erik

a meus pais, Julio César e Denise

a meus irmãos, Paulo, Daniel e Pedro 


\section{Agradecimentos}

Dedico esta dissertação, fruto de uma pesquisa que teve como maior apoiadora a minha orientadora, a Profa. Dra. Monica Tavares, que por um constante esforço e crédito na minha pesquisa me fez crescer e aprender contribuindo para meu crescimento científico e intelectual.

Agradeço as leituras feitas por Maria Ascenção Apolonia, Denise Faria e Ida Kaplanas, suas contribuições e estímulo moveram este trabalho.

Este trabalho não teria sido possível também sem o apoio incondicional de minha família e amigos que sempre presentes me deram suporte neste período de pesquisas, profícuo trabalho, disciplina e dedicação. 
"Colour is stronger than language.

It's a subliminal communication."

- Louise Bourgeois 


\section{Resumo}

No campo das Novas Tecnologias da Comunicação (NTC) se destacam determinadas obras que se caracterizam pela manipulação da cor materializada por fontes luminosas que, articulada poeticamente pelo artista, pode potencializar o diálogo entre obra e receptor. Esta dissertação pretende investigar o modo como a cor, proveniente de fonte luminosa, ao ser manipulada pelo artista, por meio de dispositivos tecnológicos das NTC, pode promover em sua obra um ambiente de sinergia e troca de informações com o receptor. Para contribuir com a compreensão do tema de modo eficaz serão abordados não somente os aspectos de ordem fisiológica, física, psíquica e cultural da cor, mas também, os seus aspectos históricos, investigando-se assim um cenário que propiciou o encontro entre a cor e a tecnologia, tornando compreensível a passagem gradual do uso da cor do objeto para a cor, como fonte de luz na arte. Serão abordados também os conceitos de obra aberta e interatividade nas NTC e sua relação com a cor como fonte luminosa.

Uma vez clarificados os conceitos de cor, luz e obra aberta, serão realizadas leituras em obras visando identificar as várias formas como a cor proveniente de fonte luminosa pode ser manipulada pelo artista, tendo em vista a função da cor como peça fundamental e ativa no diálogo entre o receptor e obra. Espera-se que, com base em determinados conceitos, seja possível apreender como o artista utilizou poeticamente a cor como fonte de luz em instalações interativas produzidas pelas NTC visando seduzir o receptor para uma relação de troca com a obra.

Palavras-chave

Cor, fonte luminosa, luz, arte digital, tecnologia, participação. 


\begin{abstract}
In the field of New Technologies of Communication (NTC) some artworks stand out because of their characteristic way of handling materialized color by light sources. Such light sources are poetically articulated by the artist, and they can enhance the dialogue between artwork and receiver. The aim of this dissertation is to investigate how the light-sourced color manipulated by the artist using NTC technological devices can promote an environment of synergy and exchange of information with the receiver. To understand this issue in an effective way, both the physiological, physical, psychological and cultural aspects of the color and its historical aspects are dealt with, thus investigating a scenery that allowed the meeting between color and technology, which made it understandable the gradual shift from the use of the color in a object to the color as a source of light in art. The concepts of open work and interactivity in the NTC and its relation to color as a light source are also discussed.
\end{abstract}

Once the concepts of color, light and open work are set, some artworks are analyzed in order to identify the several ways color from a light source can be manipulated by the artist, considering its active and fundamental role in the dialogue between receiver and artwork. Based on certain concepts, it is expected to be possible to apprehend how the artist used color poetically as a light source in interactive installations produced by NTC in order to seduce the receiver into an exchange relationship with the artwork.

Key words

Colour, light source, light, digital art, technology, participation. 


\section{Lista de Figuras}

Figura 1: Ilustração que representa o primeiro experimento feito por Newton com um prisma. . . . . . . . . . . . . . 09

Figura 2: Ilustração que representa o segundo experimento em que Newton utilizou dois prismas $\ldots \ldots \ldots \ldots \ldots \ldots \ldots \ldots$

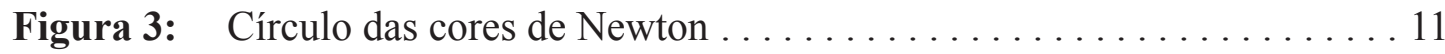

Figura 4: Anatomia ocular......................... 22

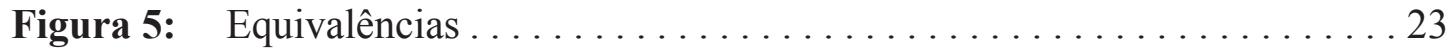

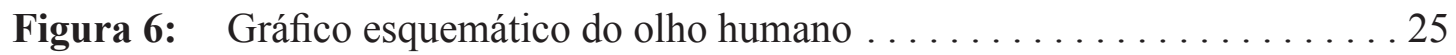

Figura 7: Vista medial do cérebro . . . . . . . . . . . . . . . . . . . . . 29

Figura 8: Estrutura de um neurônio . . . . . . . . . . . . . . . . . 29

Figura 9: Os lobos do cérebro e suas áreas especializadas . . . . . . . . . . 31

Figura 10: As vias do olho ao cérebro . . . . . . . . . . . . . . . . . 33

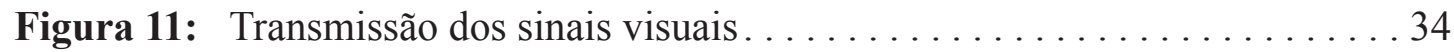

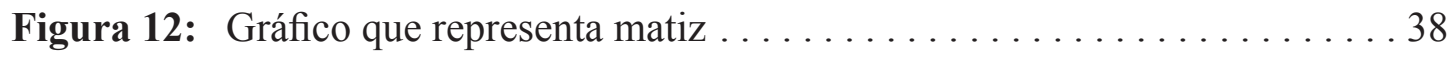

Figura 13: Gráfico que representa valor $\ldots \ldots \ldots \ldots \ldots \ldots \ldots \ldots \ldots \ldots \ldots \ldots \ldots \ldots \ldots$

Figura 14: Gráfico que representa croma. . . . . . . . . . . . . . . . . . 39

Figura 15: Gráfico que representa a mistura substrativa das cores . . . . . . . 40

Figura 16: Modelos de cores que se baseiam no sistema CMYK . . . . . . . . 41

Figura 17: Gráfico que representa a mistura aditiva das cores . . . . . . . . 41

Figura 18: Gráfico que representa as cores primárias . . . . . . . . . 43

Figura 19: Modelos de cores que se baseiam no sistema RGB. . . . . . . . . . . . 44

Figura 20: Modelos de cores que se baseiam no sistema HTML. . . . . . . . . . . . 44

Figura 21: Gráfico que representa as cores secundárias . . . . . . . . . . 45

Figura 22: Gráfico que representa as cores terciárias . . . . . . . . . . 46

Figura 23: Gráfico das cores quentes e frias de Charles Hayter (1813) . . . . . . . 47

Figura 24: Gráfico que representa as cores quentes. . . . . . . . . . . 48

Figura 25: Gráfico que representa as cores frias . . . . . . . . . . . . . 49

Figura 26: Círculo das cores de Newton . . . . . . . . . . . . . . . . . . 50

Figura 27: A árvore de Munsell . . . . . . . . . . . . . . . . . . . 50

Figura 28: Gráfico que representa as cores complementares. . . . . . . . . . 51

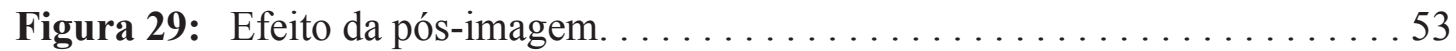

Figura 30: Contraste simultâneo em duas cores complementares . . . . . . . . 53

Figura 31: Porcentagens de luminosidade . . . . . . . . . . . . . . . . 54

Figura 32: O diagrama tricromático da composição da luz branca, síntese da parte visível do espectro solar, compreendida entre $400 \mathrm{~m} \mu$ e $700 \mathrm{~m} \mu$. . 58

Figura 33: Faixa de radiações visíveis compreendida entre os raios infravermelhos e os ultravioletas. . . . . . . . . . 58 
Figura 34: Resumo da tabela dos estímulos tricromáticos, X, Y e Z . . . . . . . . . 59

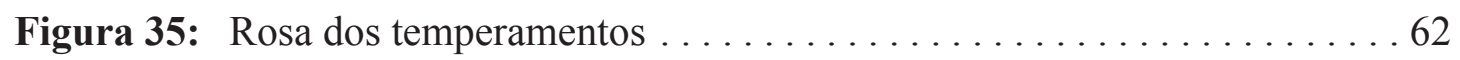

Figura 36: Diagrama dos poderes da alma. Goethe $(1807) \ldots \ldots \ldots \ldots$. . . . . 62

Figura 37: La Parade (1887-88), Georges Seurat . . . . . . . . . . . . . . . . 79

Figura 38: La Parade (1887-88) - detalhe ampliado, Georges Seurat. . . . . . . . . 79

Figura 39: Circus $(1890-91)$, Georges Seurat . . . . . . . . . . . . . . . . 80

Figura 40: Circus (1890-91) - detalhe ampliado, Georges Seurat. . . . . . . . . . 80

Figura 41: Rotary Glass Plates (1920), Marcel Duchamp. . . . . . . . . . . . 84

Figura 42: Sunday afternoon on the island of La Grande Jatte (1884-86),

Georges Seurat ........................... 92

Figura 43: Gráfico que aponta a distância média para se perceber a fusão dos elementos cromáticos de uma obra pontilhista de acordo com Pissaro . . 93

Figura 44: Sunday afternoon on the island of La Grande Jatte (1884-86) detalhe, Georges Seurat . . . . . . . . . . . . . . . . . . . . . . . . 94

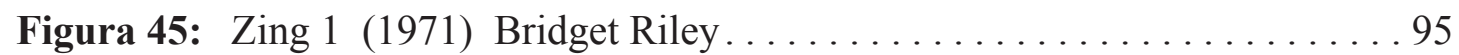

Figura 46: Aceleração Óptica (1965), Victor Vasarely . . . . . . . . . . . . . . . 95

Figura 47: Grafismos cinéticos da obra Geometrical and Optical Art de Jean Larcher. . . . . . . . . . . . . . . . . . . . . . . . . . . . . . . . . 97

Figura 48: Construção gráfica que representa a ilusão fisiológica. . . . . . . . . . . . 97

Figura 49: Monochrome Blue and Color Rhythm Polymorph, Yaacov Agam . . . 98

Figura 50: Nouveau solfège 1966, Yaacov Agam... . . . . . . . . . . . . . . 98

Figura 51: Harmonie transformable (1956), Jésus Rafael Soto. . . . . . . . . . . . . . 99

Figura 52: Structure Cinétique (1955), Jésus Rafael Soto . . . . . . . . . . . . . . . 99

Figura 53: Verde Hélène (1976), Jésus Rafael Soto . . . . . . . . . . . . . . . 100

Figura 54: Muro de cilindros excéntricos manipulables.

Caracas (1954), Cruz-Diez. . . . . . . . . . . . . . . . . . . 104

Figura 55: Proyecto para un muro exterior manipulable.

Caracas (1954), Cruz-Diez. . . . . . . . . . . . . . . . . 105

Figura 56: Jogo do Quadrado Perfeito (1971), Abraham Palatnik. . . . . . . . . . . 105

Figura 57: Aparelho Cinecromático (1958), Abraham Palatnik. . . . . . . . . . . . 107

Figura 58: Aparelho Cinecromático (1955), Abraham Palatnik. . . . . . . . . . . 107

Figura 59: Cybernetic Light Tower (1972), Nicolas Schöffer. . . . . . . . . . . . . 109

Figura 60: Móbile contínuo, luz contínua (1963), Julio Le Parc. . . . . . . . . . . . 110

Figura 61: Continuel-couleurs-lumière (1965), Julio Le Parc. . . . . . . . . . . . . 110

Figura 62: Clavilux 2000 (2009), Michael Götte e Veldana Sehic... . . . . . . . . 113

Figura 63: Clavilux 2000 (2009), Michael Götte e Veldana Sehic.. . . . . . . . . . . 113

Figura 64: LightScoop (2008), Olga Mink e Roel Verlinden. . . . . . . . . . . . . . 114

Figura 65: LightScoop (2008), Olga Mink e Roel Verlinden. . . . . . . . . . . . . . 115

Figura 66: Optone (2009), Tsutomu Mutoh. . . . . . . . . . . . . . 115 
Figura 67: Optone (2009), Tsutomu Mutoh. . . . . . . . . . . . . 116

Figura 68: Tipos de causalidade, conforme a teoria cibernética.. . . . . . . . . 117

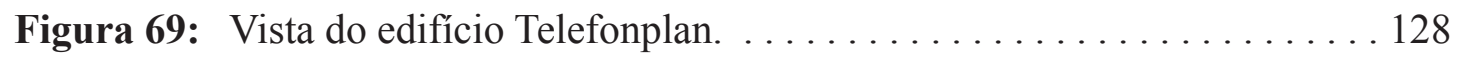

Figura 70: Forest of Light - projeção em vermelho, azul e verde. . . . . . . . . . 130

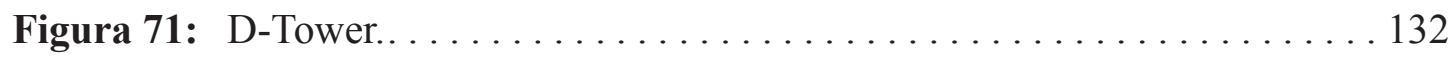

Figura 72: Gráfico com a numeração

atribuída aos andares do edifício Telefonplan............. 135

Figura 73: Gráfico que representa o controle de cores pelo teclado do celular. . . 135

Figura 74: LEDs que foram posicionados nas janelas do edifício. . . . . . . 136

Figura 75: Gráfico que representa a mistura aditiva das cores. . . . . . . . . . 137

Figura 76: Participante interagindo com a torre através do celular. . . . . . . . 137

Figura 77: Edifício Telefonplan no período em que a obra estava ativa. . . . . . 139

Figura 78: Edifício Telefonplan no período em que a obra estava ativa. . . . . . . 141

Figura 79: Gráfico estrutural da obra Forest of Light. . . . . . . . . . . . . . . . . 142

Figura 80: Gráfico estrutural da obra Forest of Light. . . . . . . . . . . . . 144

Figura 81: Participantes acionando a obra por meio de seu movimento . . . . . . 145

Figura 82: Participantes acionando a obra por meio de seu movimento. . . . . . 147

Figura 83: Floresta iluminada pelas projeções de luz.. . . . . . . . . . . . . . . . 148

Figura 84: D-Tower. . . . . . . . . . . . . . . . . . . . . . . . . . . . . 149

Figura 85: Estrutura da torre em vista explodida. . . . . . . . . . . . 151

Figura 86: Fases da construção . . . . . . . . . . . . . . . . 151

Figura 87: Modelo de algumas questões recebidas pelos participantes. . . . . . 153

Figura 88: Gráficos emocionais dos sentimentos de amor e felicidade. . . . . . . 154

Figura 89: Torre iluminada em azul (felicidade) e vermelho (amor). . . . . . . . 155

Figura 90: Torre iluminada em verde (ódio) e amarelo (medo). . . . . . . . . . 156

Figura 91: Gráfico esquemático dos princípios de uma lâmpada eletroluminescente. . . . . . . . . . . . . 181

Figura 92: Modelo de lâmpada eletroluminescente em forma de rolo

extrudada utilizada para marcar os degraus de uma escadaria. . . . . . 182

Figura 93: Cabos eletroluminescentes . . . . . . . . . . . . . . . . 182

Figura 94: Diagrama com a composição do LED... . . . . . . . . . . . . 183

Figura 95: Nesta fachada os LEDs tiveram a mesma performance de uma

luz neon quando agrupados lado a lado e internos a um tubo plástico . 184

Figura 96: Iluminação colorida por meio da mistura de três cores de LED. . . . . 184

Figura 97: Diversos modelos estruturais onde os LEDs podem ser aplicados. . . 185

Figura 98: Fachada que utiliza os LEDs como dispositivo para iluminação.

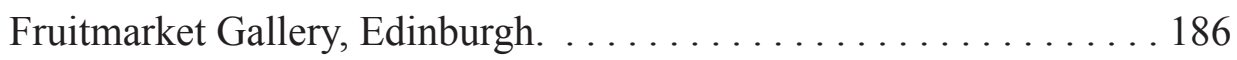

Figura 99: Ilustração que apresenta os princípios da fibra óptica. . . . . . . . . . 187

Figura 100: Fibra Óptica . . . . . . . . . . . . . . . . . . . . . . 187 


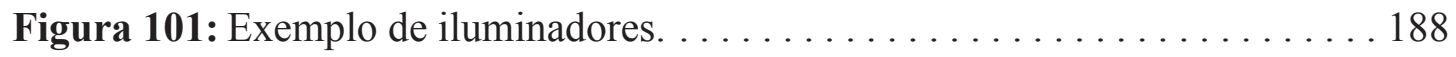

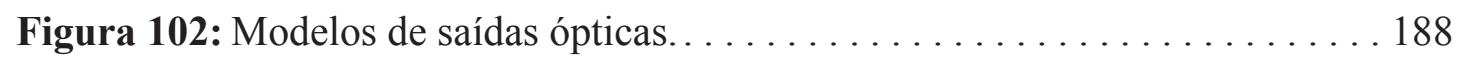

Figura 103: Iluminação feita por um sistema de luzes ópticas . . . . . . . . . . . . . 189

Figura 104: Telas de CRT utilizadas como principal fonte

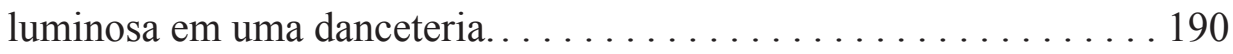

Figura 105: Diagrama esquemático de um CRT. . . . . . . . . . . . . . . . . 190

Figura 106: Vista aproximada da tela de um monitor CRT. . . . . . . . . . . . . . 191

Figura 107: Moléculas de cristal líquido. . . . . . . . . . . . . . . . . . . 192

Figura 108: Orientação esquemática das moléculas em

líquido nemático entre duas lâminas de vidro . . . . . . . . . . . . 192

Figura 109: Sensores sensíveis à luz.. . . . . . . . . . . . . . . . . . . . . 193

Figura 110: Príncipio de funcionamento dos sensores de feixe. . . . . . . . . . . . . 194

Figura 112: Arranjo de lentes típico de um sensor PIR. . . . . . . . . . . . . . . 194

Figura 113: Diagrama da área de detecção de um PIR, apresentando a configuração comum dos feixes correspondetes as 16 lentes presentes no sensor . . . . 195

Figura 114: Sensor que combina detecção ultrasonica e PIR . . . . . . . . . . . 196 


\section{Sumário}

Introdução

\section{Capítulo 1.}

Aspectos históricos 05

1.1. Principais linhas de pesquisa no campo da cor como fonte luminosa.......................06

1.2. Estudos relevantes no campo da cor, da luz e da eletricidade ..................................... 08

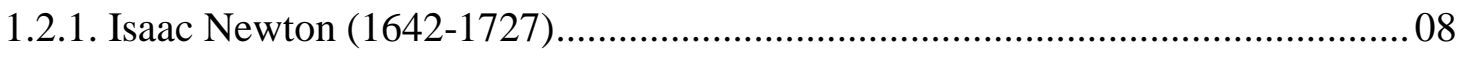

1.2.2. Johann Wolfgang von Goethe (1749-1832) .................................................. 12

1.2.3. Thomas Young (1773-1829) e Hermann L. F. von Helmholtz (1821-1894) ..... 14

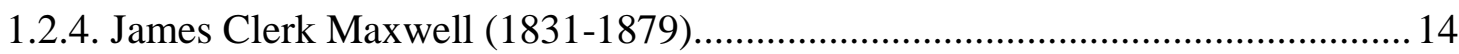

1.3. Principais contribuições científicas para o uso da cor como fonte luminosa ..............15

\section{Capítulo 2.}

Da cor à luz

2.1. Aspectos fisiológicos da cor 21

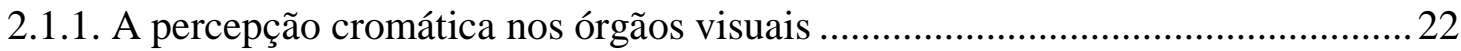

2.1.2. O processo neurológico na visão cromática ........................................................2 27

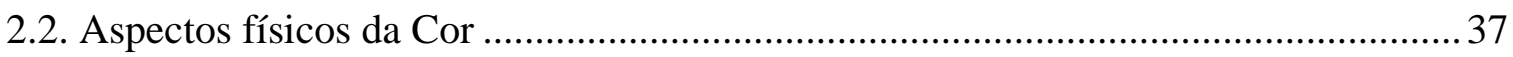

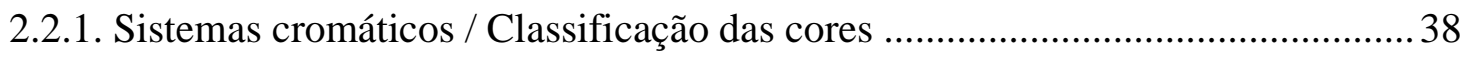

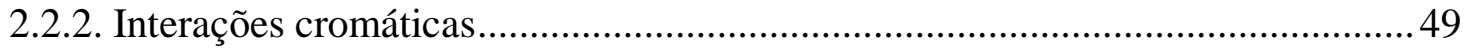

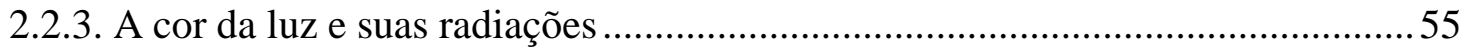

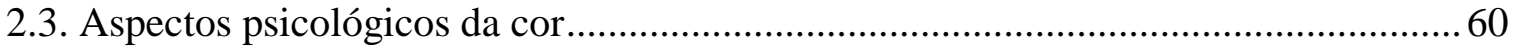

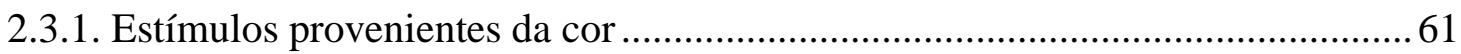

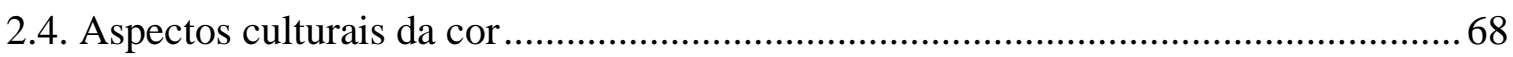




\section{Capítulo 3.}

A busca da inserção do receptor pela cor como fonte luminosa na arte .73

3.1. Eventos que contribuíram para o encontro entre ciência e arte ................................. 74

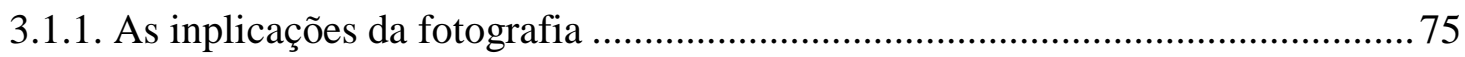

3.1.2. As primeiras "tímidas" propostas de fusão entre ciência e cor na arte................77

3.2. O impacto tecnológico no uso da luz como fonte luminosa...................................... 82

3.2.1. Visão geral de algumas premissas (pressupostos) da obra aberta ....................... 88

3.2.2. Da obra aberta à participação mediada corporal(mente) ................................... 91

3.2.3. Da obra em movimento às participações mediadas corporalmente, automaticamente e instantaneamente .................................. 101

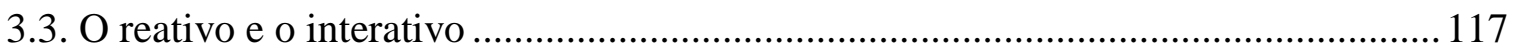

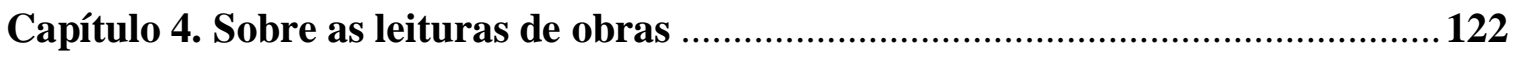

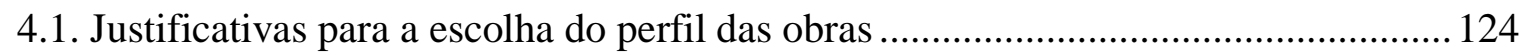

4.1.1. Características em comum utilizadas na seleção das obras ............................... 124

4.1.2. Justificativa do porquê dessas características e sua relevância em relação ao tema central da dissertação..................................................... 125

4.2. Apresentação das obras e justificativas ................................................................. 128

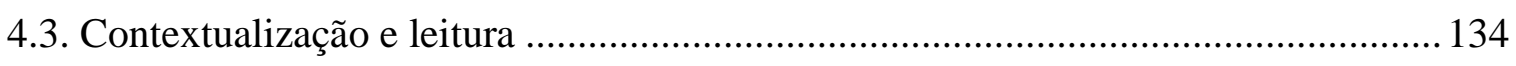

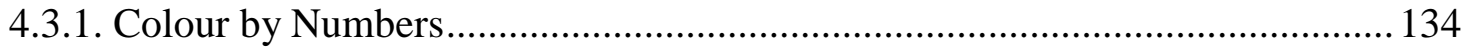

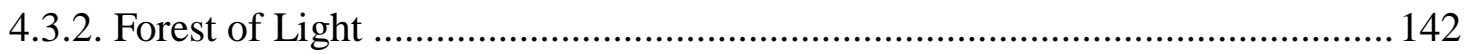

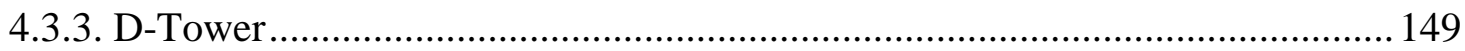

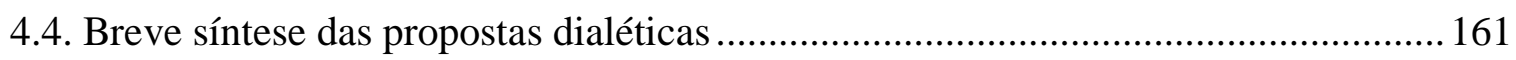

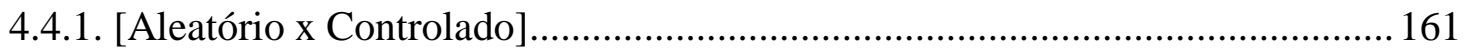

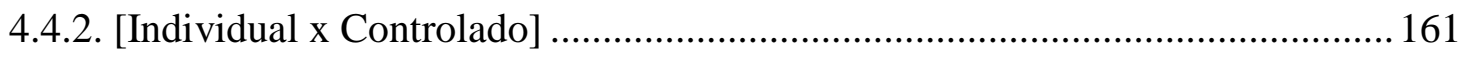

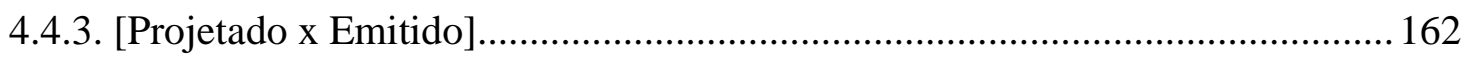

4.4.4. [Informação Estética x Semântica] ................................................................ 163

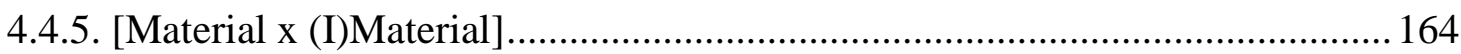

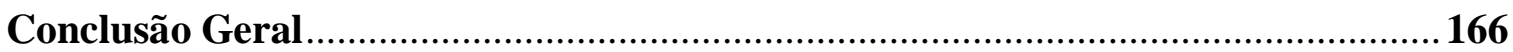

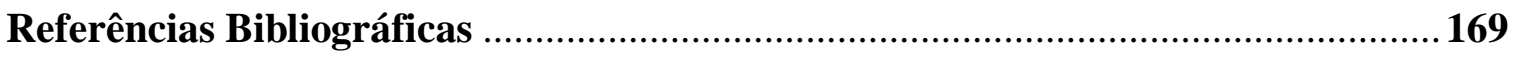


A. Questões Apresentadas aos artistas responsáveis por cada obra ......................... 175

B. Resposta enviada pelos artistas Erik Krikortz, Loove Broms e Milo Lavén a respeito da obra Colour by Numbers

C. Diálogos com a artista Christina Okai Mejborn (TotemCollective), a respeito da obra "Forest of Light".

D. Resposta enviada pelo artista Q.S. Serafijn a respeito da obra D-Tower 182

Anexo 2. Dispositivos de interatividade que manipulam as fontes luminosas coloridas 


\section{Introdução}

O tema da cor sempre foi recorrente em meus estudos. $\mathrm{O}$ meu interesse pelo estudo da cor no âmbito das Novas Tecnologias da Comunicação (NTC) surgiu em 2008, durante o curso de Mestrado do programa de Pós-Graduação em Artes Visuais da Escola de Comunicações e Artes (ECA-USP) na linha de pesquisa de Multimeios. No período em que passei a ter contato com esse novo campo da arte tecnológica ocorreu-me que seria oportuno cruzar essas duas áreas e ampliar minha compreensão sobre o processo poético dos artistas que, pela manipulação da cor, conferiam a esse tipo de arte uma relação dinâmica com o fruidor/receptor. O desafio, então, seria identificar, nessa relação "receptor-obra", o papel da cor como um agente facilitador do processo de inserção do receptor, e como o artista abordaria essa questão, intensificando potencialmente esse diálogo.

O campo de estudo da cor é bastante extenso. Muitas obras já foram escritas a esse respeito. Minha intenção é dirigir o foco deste estudo para os diferentes modos de recepção das manifestações artísticas que dialogam com o receptor, dando ênfase às obras de cunho tecnológico, em que a cor, representada através de fontes luminosas, é um elemento estrutural da obra, caso das instalações interativas nas quais a luz é a forma principal de expressão. Dessa maneira, a cor como fonte luminosa passa a ter uma importância maior nesta pesquisa, deslocando-se do uso da cor do objeto como forma de expressão.

Com a finalidade de apreender a poética da cor utilizada pelos artistas nas instalações interativas das NTC será necessário recuperar os dados históricos dos quais decorrem seus aspectos fisiológicos, físicos, psicológicos e culturais. Será igualmente fundamental, para identificar nas obras a relação e inserção do receptor, reconhecer os mecanismos inerentes às práticas participativas da obra aberta. 
Os aspectos históricos da teoria cromática fornecerão uma base para melhor compreendermos os estudos, as pesquisas e os tratados que influenciaram artistas e que contribuíram para a formação do cenário atual das artes tecnológicas. Os aspectos físicos, fisiológicos, psicológicos e culturais da cor servirão para descrevê-la de maneira geral e precisa, tendendo a buscar nela sua relação com o homem; posteriormente seu estudo mais direto como fonte luminosa revelará suas propriedades e sua contribuição para a arte tecnológica. E quanto aos mecanismos da obra aberta, estes deverão esclarecer como se dá o processo de interação do receptor com a arte e a poética de criação.

Com base nessas informações e conhecendo de maneira mais aprofundada esses fundamentos, partirei para o estágio de leitura de obras que, previamente selecionadas, auxiliarão no destaque de determinados conceitos que ajudem a detectar como o artista utilizou poeticamente a cor como fonte luminosa. Para facilitar esse processo serão utilizadas algumas estratégias de pesquisa, como entrevistas e registros ditados de cada artista.

Será importante apontar na pesquisa a passagem gradual do uso da cor do objeto para o uso da cor como fonte luminosa numa obra de arte, fato esse que demonstra claramente a importância da tecnologia na arte contemporânea. Essa passagem se dá aos poucos à medida que a ciência e a arte timidamente começam a se relacionar no fim do século XIX. Estudos, tratados, teorias das cores e os avanços tecnológicos no campo da luz sempre atraíram artistas de todos os tempos. De lá para cá essa união vem se consolidando cada vez mais, sendo que hoje algumas tecnologias utilizadas na arte são desconhecidas do individuo comum. De acordo com Couchout:

Nos dias de hoje, descobrimos com frequiência nas proposições artísticas aplicações tecnológicas que põem em uso o que o numérico possui de mais específico e mais novo e cujo uso comum ainda não foi autorizado (COUCHOT, 2003, p.12).

A proposta da pesquisa é, então, a de apreender a poética utilizada pelos artistas ao manipular a cor como fonte luminosa nas instalações interativas das NTC e compreender como ela pode potencializar esse diálogo ao seduzir o receptor. Com isso, objetiva-se ampliar o campo de pesquisa nessa área do conhecimento, servindo este 
estudo como futuro manancial de pesquisa para os interessados no uso da cor como fonte de luz nas obras abertas ao receptor.

Nesta pesquisa, é imperioso aprofundar a discussão cromática na arte para que seja possível avaliar a importância da cor como fonte luminosa no papel de elemento transmissor de informações em uma obra de arte aberta, atuando como intermediário entre a obra e o receptor. Também se objetiva explicitar a forma como a presença da cor como fonte luminosa facilita e torna possível esse diálogo, se bem usada pelo artista. Certamente as entrevistas feitas com artistas criadores de instalações interativas que utilizam a cor de fonte luminosa como elemento de expressão e significação serão elucidativas, nesse sentido.

É necessário esclarecer que essa leitura e a compreensão de como o artista utilizou poeticamente a cor possuem certos limites, pois é difícil visualizar uma linha que divida o modo de seleção racional dos processos cognitivos de escolha e sensibilidade, utilizado pelo artista e que são individuais para cada personalidade. Isso exigiria o envolvimento de outras áreas de conhecimento, como a psicologia, por exemplo. Portanto, o que se espera dessas leituras é que elas tentem dar conta do percurso proposto pelo artista e de como a cor, fonte luminosa, foi tratada de modo a poeticamente inserir o receptor.

Esta dissertação está dividida em quatro capítulos descritos a seguir:

O primeiro capítulo apresentará um panorama histórico dos principais acontecimentos e descobertas vinculados ao estudo da cor como fonte luminosa. O seu objetivo é resgatar as principais contribuições científicas para o desenvolvimento do estudo da cor derivada da luz. Tais contribuições serão expostas em ordem cronológica, dando a conhecer a relevância dos estudos de Isaac Newton (1642-1727), Johann Wolfgang von Goethe (1749-1832), Thomas Young (1773-1829), Hermann L. F. Von Helmholtz (1821-1894) e James Clerk Maxwell (1831-1879). Pretende-se de modo sincrônico destacar como tais contributos científicos estão na base das experimentações artísticas digitais. 
O segundo capítulo procura definir os conceitos da cor como um todo, abordando seus aspectos fisiológicos, físicos, psicológicos e culturais, estabelecendo assim uma base para a compreensão dos conceitos que envolvem as propriedades físicas e sensoriais da cor. Neste capítulo é ressaltada a importância de se perceber a cor não somente como elemento físico mas subjetivo. Para estabelecer o recorte proposto pela pesquisa, será dada ênfase ao estudo da cor como fonte luminosa, introduzindo suas propriedades físicas e fenômenos a ela relacionados.

O terceiro capítulo irá investigar o conceito de obra aberta e explicitará o papel que o receptor tem desempenhado e a sua importância no contexto da participação. Para garantir um melhor embasamento serão levantados os aspectos históricos da atuação do receptor desde que ele passou a representar na obra de arte um papel participativo e fundamental como quando do advento da fotografia. Será revisto o impacto que a chegada das tecnologias causou na produção artística trazendo ferramentas para uma prática da interação cada vez mais acessível ao receptor. Nesse capítulo, serão ressaltadas a participação do receptor e de que forma, sob o ponto de vista artesanal, mecânico e instantâneo, pode se dar a interação da obra pela cor assumindo esta o papel principal de mediadora entre obra e receptor.

O quarto capítulo será dedicado às leituras de obras abertas das NTC que utilizam a cor como fonte luminosa no papel de elemento transmissor de informação. Objetiva-se desta forma destacar determinados conceitos que ajudem a detectar como o artista utilizou poeticamente a cor como fonte luminosa a fim de aproximar o receptor da obra. Para facilitar a leitura da poética do artista, serão feitas entrevistas com os autores de cada obra, visando investigar de maneira mais precisa a forma pela qual cada um se utilizou da cor como fonte luminosa. Todas as obras lidas se referem a obras abertas, cujo papel participativo do receptor se mostra essencial e onde a cor como fonte luminosa se apresenta como um elemento que intermediará esse diálogo de maneira efetiva. No decorrer das leituras serão feitas correlações com os estudos abordados nos capítulos anteriores de modo a se alcançar os objetivos propostos. Desta forma, com as conclusões das leituras, espera-se compreender de que forma a cor seduz o receptor de modo a facilitar o diálogo entre ele e a obra, e com isso levá-lo a apreender e reler o processo poético utilizado pelos artistas. 
"The starting point is the study of colours and its effects on men."

Wassily Kandinsky 


\section{Capítulo 1}

\section{Aspectos históricos}

Ao adentrar esse campo investigatório das relações cromáticas é tarefa essencial buscar embasamento nos registros históricos que sirvam de referência para o estudo do tema. A história é parte fundamental para nos situar e nos fazer compreender os diferentes aspectos da sociedade atual na qual estamos inseridos. Sem o conhecimento do passado, não temos referências, embasamento e nem idéia de como o atual sobreveio.

Este capítulo traçará um panorama histórico, em que será possível resgatar os escritos e as teorias cromáticas que agregaram informações e dados para o desenvolvimento do estudo sobre a cor como fonte luminosa no cruzamento entre ciência, tecnologia e arte. Em razão do objeto desta pesquisa ser a cor como fonte luminosa, ao investigarmos sua natureza somos levados a complementar os estudos cromáticos com os estudos da luz e seus fenômenos. No caso das instalações artísticas das Novas Tecnologias da Comunicação (NTC), nas quais a fonte emite luz colorida artificialmente por meio de dispositivos tecnológicos, existem fenômenos vinculados a esses efeitos cuja origem é de ordem elétrica e magnética.

Os fenômenos cromáticos e de luz sempre foram tratados como sendo de origens distintas, o mesmo ocorrendo com os fenômenos elétricos e a luz. Foi a partir de pesquisas e descobertas, que a ciência pôde correlacionar estas áreas contribuindo para um grande avanço no estudo da cor como fonte luminosa, evidenciando-se hoje que tais campos se mostram indissociáveis.

O ser humano sempre conviveu com a cor. Mas só veio a desvendar suas propriedades e os mecanismos da visão mais tarde. Segundo nos conta Guimarães (2000, p.2), em seu livro A cor como informação: a construção biofísica, linguística e cultural da simbologia das cores, foi, a partir do século XV, que surgiram os primeiros tratados escritos por pintores e estudos de filósofos, matemáticos e físicos no campo da cor. Os avanços da óptica e a idéia de que a luz solar seria composta por cores mudou por 
completo o caminho dos estudos cromáticos, acelerando sensivelmente o desenvolvimento científico na área tecnológica até os dias atuais.

Desde o início dos tempos, o homem se utilizou da cor como um agente comunicador, que carrega informações que lhe foram reveladas ao longo das gerações. Dessa maneira, entende-se que cada cor possui um significado simbólico que é peculiar à cada cultura. De fato, as cores foram utilizadas como elementos representativos de informações e se tornaram úteis à sociedade na criação e no desenvolvimento de códigos cromáticos que sinalizam, influenciam e comunicam. Neste estudo iremos nos ater à cultura ocidental, pois é nela que estão situadas as obras, os tratados e os pesquisadores sobre as quais esta pesquisa irá discorrer.

A cor influencia tudo, modelando, acidentalmente ou intencionalmente, nossa percepção. Pode comunicar complexas interações de associação e simbolismo ou uma simples mensagem, mais clara que as palavras (FRASER; BANKS, 2007, p.6).

A proposta de teorizar as cores e a elas associar significados data de muito longe. Os homens sempre relacionaram às cores simbologias e crenças que foram compartilhadas nas sociedades. O objetivo sempre foi o de desvendar o poder e a origem que cada cor detinha em sua estrutura. E cada cultura soube, ao longo do tempo, encontrar os caminhos para associar cada cor a seus significados e crenças. Não demorou muito até que a ciência e a busca pela racionalização se tornaram imperativas e procuraram desvendar as propriedades intrínsecas à cor, bem como os mistérios de sua influência no ser humano.

\subsection{Principais linhas de pesquisa no campo da cor como fonte luminosa}

O fato de a cor ser um agente "poderoso", cuja formulação pode ser capaz de modificar um pensamento, alterar o humor e influenciar as pessoas, chamou a atenção e tornou-se tema de estudo de muitos pesquisadores e cientistas, mais intensamente nos dois últimos séculos. O tema da cor sempre esteve no limiar de diversas ciências, e talvez se deva a isso, o fato de pesquisadores de áreas tão distintas como filosofia, psicologia, física, química e artes terem se interessado pelo estudo da cor. Mas, cada qual por um ponto de vista diferente, utilizando análises e métodos específicos. Como resultado desse grande interesse nos estudos cromáticos, encontramos hoje um acúmulo de diversas teorias e 
estudos que trouxeram ao campo da cor respostas a muitas dúvidas e, ao mesmo tempo, avanços no campo tecnológico no que tange à cor como fonte luminosa nos séculos XIX e XX.

A grande descoberta, que trouxe enorme avanço tecnológico em prol do uso da cor como fonte luminosa foi a de ordem eletromagnética. Com esse conhecimento se tornaram compreensíveis os processos de produção, absorção e propagação da luz de uma maneira unificada.

Este capítulo então se ocupará de traçar um panorama histórico da cor como fonte luminosa e se concentrará nas pesquisas que trouxeram grande impacto para o entendimento da cor gerada artificialmente, e sua associação com os órgãos visuais e os sentidos. A primeira grande descoberta nesse sentido foi feita pelo físico inglês Isaac Newton (1642-1727), cuja base científica possibilitou compreender que as cores estariam presentes na luz solar. Esse pensamento, que até então não fazia sentido, provou ser extremamente importante, para a evolução da ciência, os estudos ópticos, do comportamento e das propriedades da luz. Os escritos e registros de Newton, conforme relata Bouma (1947, p.14), serviram como base para que novos pesquisadores dessem continuidade e aprimorassem os conceitos sobre a cor. Para Newton, toda a cor, em sua essência, é um efeito da luz branca. Contrapondo em partes a visão de Newton, aparecem os estudos do filósofo alemão Goethe (1749-1832) que, segundo Bouma (1947, p.204), enveredou pelo estudo das cores no intuito de discutir determinadas idéias que Newton publicara em seu livro Opticks (1704). Goethe se diferencia de Newton, ao analisar a cor sob um ponto de vista mais empírico, dando ênfase à sensação da cor mais do que à determinação de sua natureza. A abordagem dada por Goethe em sua obra Doutrina das Cores (1810) será discutida posteriormente, a fim de se obterem dados que nos levem a compreender seu entendimento da cor e qual a relação desta com o ser humano.

Seguindo uma ordem cronológica, é relevante falar sobre Thomas Young (1773-1829) que, de acordo com Bouma (1947, p.206), tornou compreensível, por meio de extensas pesquisas, o processo pelo qual o órgão visual humano processa a entrada de luz e o modo como ocorre a identificação das cores, dando a conhecer o fato de que nossa visão é composta por uma mistura óptica aditiva, que se processa em nossos olhos. 
Complementando os estudos, no campo da óptica fisiológica, realizados por Young, Helmholtz (1821-1894) contribuiu para a teoria tricromática das cores, conferindo-lhe um caráter mais científico. Finalmente, para completar o quadro de pesquisadores, será citado Maxwell (1831-1879) que teve grande importância na história da ciência, ao relacionar os efeitos elétricos e magnéticos aos fenômenos ligados à luz.

\subsection{Estudos relevantes no campo da cor, da luz e da eletricidade}

A seguir trataremos mais detalhadamente cada uma das personalidades referidas que, a nosso ver, causaram um grande impacto na compreenção gradativa da cor como fonte luminosa e, desta forma, influenciaram as produções artísticas e tecnológicas do mundo contemporâneo.

\subsubsection{Isaac Newton (1642-1727)}

Isaac Newton foi um importante físico inglês, pioneiro no estudo da óptica, cujas descobertas marcaram a história no campo da ciência e da cultura universal. Até os dias atuais os físicos modernos fazem uso de sua lei da gravitação universal. Com base em Guicciardini (2005, p.4), Newton desenvolveu no decorrer de sua vida um grande número de leis e teorias que até hoje são utilizadas: a dinâmica newtoniana, as leis do movimento e a teoria da gravitação.

Mas foi no campo da óptica que Newton desenvolveu os estudos sobre cor e luz, as quais viriam a se tornar um marco para a física experimental. Segundo Guimarães (2000, p.8), Newton iniciara suas pesquisas a respeito da refração da luz impulsionado pela publicação da Lei correta da refração, em 1637-8, no Discours de la méthode, de René Descartes (1596-1650). Naquele período as pessoas acreditavam que as cores derivavam de uma mistura entre luz e escuridão.

[...] Descartes concebe a luz como uma pressão exercida por minúsculas partículas de éter, supondo-se que o meio preencha o espaço entre os corpos. Essas partículas têm "tendência" a se deslocar em linha reta e a girar sobre si mesmas. Quando a luz branca, considerada como um movimento de pequenas esferas, é refletida ou refratada, as partículas adquirem um movimento de rotação suplementar que está na origem da impressão de cor. A textura diferente da superfície dos corpos provoca rotações mais ou menos rápidas, daí as diferentes cores (GUICCIARDINI, 2005, p. 27). 
Newton achava pouco provável que a teoria de Descartes fosse correta e, para provar a visão contrária, ele realizou em 1666 seu primeiro experimento com a luz, utilizando para isso um prisma que, segundo Guicciardini (2005, p. 27), teria sido adquirido no ano anterior em uma feira de Sturbridge. Nesses experimentos Newton decompôs um feixe de luz branca através de um prisma e, como resultado, obteve as sete cores espectrais, que são: vermelho, laranja, amarelo, verde, azul, índigo e violeta.

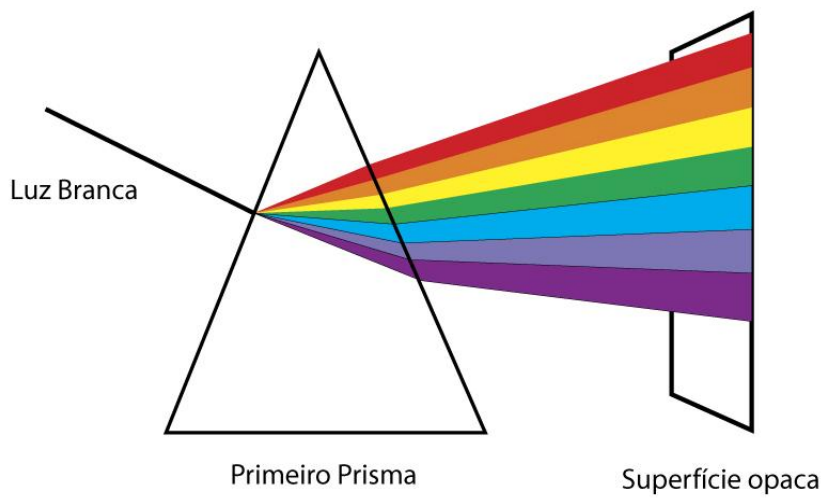

Figura 1: Ilustração que representa o primeiro experimento feito por Newton com um prisma. Fonte: Ilustração de acordo com Gage (1999, p.133)

Segundo Pedrosa (2009, p.60), esse processo de decomposição da luz branca pelo prisma permitiu-lhe deduzir que a separação espacial das cores simples é obtida graças ao grau diferente de refração de cada cor, revelado ao atravessar os corpos transparentes. Essa refração seria então caracterizada pela grandeza denominada índice de refração. Ainda de acordo com o autor, as aferições dos raios refratados possibilitaram a Newton desvincular a noção de cor do âmbito das impressões subjetivas, para introduzi-la no caminho das medidas e verificações matemáticas. A cor, aos poucos, deixava para trás seu caráter misterioso para ser decifrada de maneira racional.

De acordo com Pedrosa (2009, p. 60), para comprovar sua teoria de que a luz branca seria composta pelas sete cores do espectro, Newton realizou um experimento complementar ao do prisma isolado. Ele adicionou um segundo prisma, numa posição invertida ao primeiro, de tal modo que este último recebesse um dos feixes de cor do primeiro, que seria isolado com o auxílio de uma superfície opaca com um orifício. O resultado foi que o segundo prisma desviou a mesma cor sem modificá-la. Esse experimento provou assim o efeito da refração, dando razão a Newton em relação à teoria das cores de Descartes, evidenciando, também a verdade sobre as idéias errôneas 
de muitos cientistas que, na metade do século XVII, acreditavam que o prisma "coloria" a luz solar.

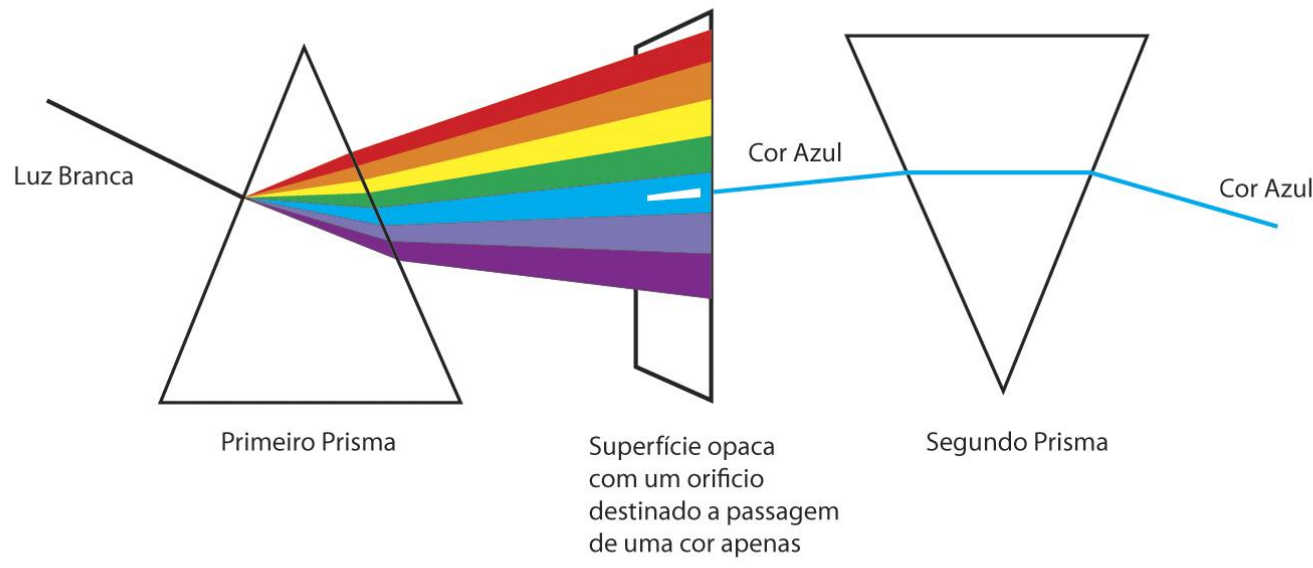

Figura 2: Ilustração que representa o segundo experimento em que Newton utilizou dois prismas.

Fonte: Ilustração de acordo com Gage (1999, p.133)

Em 1704, Newton apresentou os resultados de suas pesquisas, que foram expostas de maneira bastante experimental em sua obra Opticks: or a treatise of the reflections, refractions, inflections \& colours of light, na qual demonstra a tese de que as cores são originárias da luz. A seguir, citamos um trecho de sua obra Opticks, no qual Newton conclui que as cores não são modificações da luz branca, mas dela fazem parte:

As cores não são qualificações da luz, derivadas das refrações ou reflexões dos corpos naturais (como se acredita geralmente); são propriedades originais e inatas que diferem em raios diferentes. Alguns raios tendem a apresentar uma cor vermelha e nenhuma outra, outros uma cor amarela e nenhuma outra, outras uma cor verde e nenhuma outra, e assim por diante. Não há apenas raios próprios e particulares às cores mais dominantes, e sim a todas as suas gradações intermediárias (NEWTON, 1996 apud GUIMARÃES, 2000, p.9).

Segundo Guimarães (2000, p.9), outra tese defendida por Newton foi a das cores permanentes dos corpos naturais por meio da absorção e reflexão dos raios luminosos. Ao contrário da cor como propriedade dos corpos, Newton defendeu as propriedades da combinação de reflexão e absorção dos raios luminosos realizada pelos corpos, que lhes conferem cores permanentes sob iluminação de mesma qualidade. 
Foi Newton quem, em 1666, propôs o primeiro disco cromático onde, segundo Pedrosa (2009, p.61), posicionou as sete cores visíveis do espectro em um gráfico circular. Ele posicionou a cor branca no centro e as sete cores espectrais ao redor desta, sendo as cores periféricas ao centro as menos saturadas e ganhando saturação a medida que se aproximam do eixo central. Newton nomeou as cores opostas pelo eixo central de "cores complementares". A idéia de Newton era a de que, ao misturar as cores complementares do disco, ele obteria cores neutras ou anônimas. É importante destacar que esse disco até hoje é usado por artistas. Serviu de referência para estudos posteriores que tentavam compreender e selecionar de uma maneira lógica e seqüenciada as cores, buscando dados de harmonia e combinações. O disco cromático de Newton permanece essencialmente o mesmo até hoje.

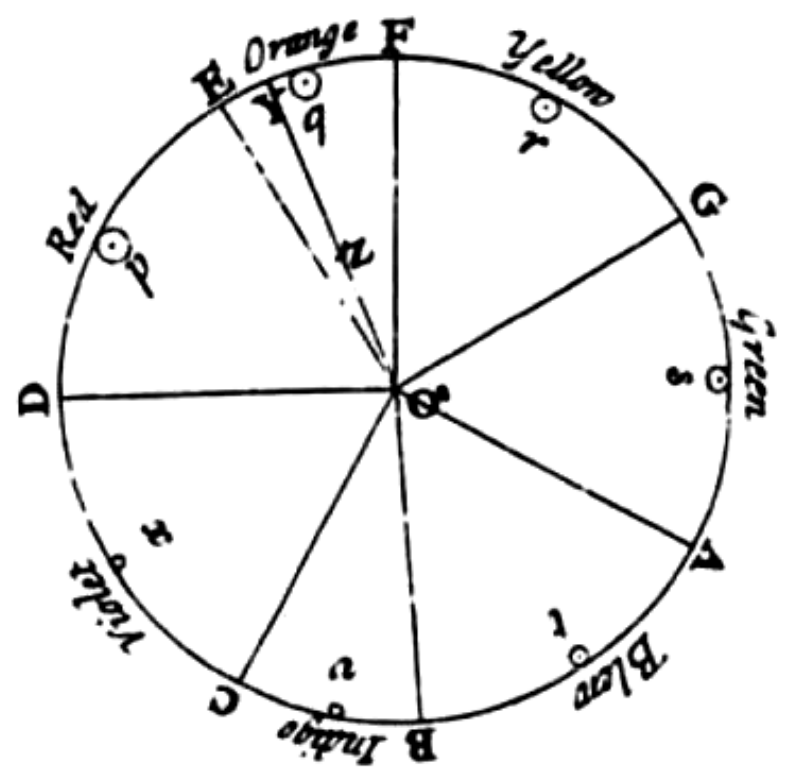

Figura 3: Círculo das cores de Newton. Fonte: (GAGE, 1999, p.136)

Com esses resultados, Newton lançou bases para uma nova fase, em que o estudo das cores passou a ser tratado cientificamente e se tornou um assunto de interesse interdisciplinar. As teorias atuais das cores se basearam e têm sua origem nos estudos de Newton. 


\subsubsection{Johann Wolfgang von Goethe (1749-1832)}

Depois que Newton publicou seus experimentos no livro Opticks em 1704, muitos se apoiaram em suas teorias. Durante o século XVIII, era possível notar essa tendência de maneira clara e imperativa, mas foi no final desse século e início do século XIX que uma figura importante no campo das letras, Johann Wolfgang von Goethe, filósofo alemão, interessou-se pelos estudos cromáticos objetivando provar o contrário sobre alguns conceitos de Newton. Segundo Lichtenstein (2006, p. 72), esse período representou uma nova concepção da cor em sua realidade psicológica, fisiológica e estética, e o maior obstáculo posto à frente deste novo ideal seriam as teorias de Newton.

O fato de Newton e Goethe atuarem em áreas totalmente distintas explica, em parte, o fato de ambos pensarem a mesma teoria de maneira diferente. O ponto crucial dessa distinção é o fato de que, para Newton, todos os seus experimentos eram determinados independentemente do observador, eram determinados por leis restritas e feitos de maneira estritamente calculada. Contrapondo essa visão, Goethe via o homem como o elemento central de suas observações. Segundo Bouma (1947, p. 204), o propósito das investigações de Goethe era descobrir como essas impressões da cor subjetiva e das correspondentes sensações desencadeadas no ser humano se originariam e como sofreriam o influxo das circunstâncias.

Em todas as experiências que Goethe reproduziu e realizou, o ponto central de observação era o homem e, dessa forma, o observador era tratado como parte integrante das experiências cromáticas ou, como diria Crary (1988, p. 4), o corpo humano passa a ser um produtor ativo de uma experiência óptica.

Em 1810, Goethe publicou seu livro Doutrina das Cores, que até hoje é considerado o estudo mais detalhado sobre as cores sob todos os pontos de vista, e conta com tradução em diversas línguas. Seus estudos até hoje são utilizados por historiadores e cientistas na discussão do tema cor.

Na Doutrina das Cores, Goethe se preocupou em estudar a origem das cores na interação entre luz e sombra e, de acordo com Barros (2007, p.277), enfatizou o significado das cores, "estabelecendo entre elas relações dialéticas, como a polaridade, e 
ressaltando as compensações causadas pelo órgão visual na intensificação de contrastes". Esta obra de Goethe, foi uma compilação rigorosa, de caráter empírico com estudos de cunho científico e literário, a respeito da cor registrada ao longo de vários anos. De acordo com Argan (1999, p.02), Goethe pretendia apreender como o olho se comporta no curso de uma percepção que não é nunca instantânea. A análise que Goethe realizava era a análise de um processo mental. Para Goethe, o objetivo principal de sua obra era demonstrar a questão da objetividade e da subjetividade do conhecimento. Ainda segundo o mesmo autor, Goethe concentra sua investigação para estudar a cor nos processos delicados que o olho percorre para ver a cor, revelando dessa forma a estrutura da mente pensante.

O olho está organizado para captar os fenômenos luminosos e cromáticos, portanto, nada melhor que o olho para poder informar sobre aqueles fenômenos mesmos: eis porque uma teoria das cores não é senão uma análise das atividades do olho. As cores são exatamente produto desta atividade (ARGAN, 1999, p.05).

Goethe concluiu em seu livro que existiam três formas de manifestação do fenômeno cromático, sendo a primeira as cores fisiológicas, que fazem parte dos olhos e que deles dependem pela sua capacidade de ação e reação, a segunda forma seriam as cores físicas, cuja origem são as fontes de luz refletidas pelos objetos coloridos (cor como fonte luminosa), e a última seriam as cores em sua forma química, dependentes das substâncias químicas que formam os objetos (cor do objeto).

$\mathrm{Na}$ parte final de sua obra, Goethe introduz pela primeira vez, de acordo com Barros (2007, p.283), uma “abordagem simbólica da cor, descrevendo estados de ânimo e sensações específicas associadas a cada uma das cores do círculo." Nesta parte final, Goethe também fala sobre harmonia e combinações.

De acordo com Pedrosa (2009, p.72), esta parte final da obra de Goethe "forneceria os elementos fundamentais para o desenvolvimento dos estudos psicológicos da cor e constituiria a base da nova simbologia cromática espiritualista”. 


\subsubsection{Thomas Young (1773-1829) e Hermann L. F. von Helmholtz (1821-1894)}

Foi o inglês Thomas Young - médico, fisiologista, físico, lingüista e egiptólogo -, aquele que inaugurou a chamada Óptica Fisiológica, a partir de sua teoria sobre as cores tricromáticas desenvolvida em 1801. Segundo Bouma (1947, p.207), Young foi o primeiro a levantar a hipótese de que a visão da cor dependia da presença de três distintos órgãos sensíveis à luz. Young defendia que a visão seria o resultado de uma síntese aditiva envolvendo três receptores (cones) responsáveis pelas cores vermelho, verde e azul, e que a partir destas cores seria possível alcançar qualquer outra cor contida no espectro pela luz.

A fim de dar continuidade aos estudos de Young, o alemão Hermann Ludwig von Helmholtz, segundo Bouma (1947, p.209), retomou suas pesquisas a respeito da teoria tricromática, dando a ela um caráter mais científico.

Desenvolveu o traçado das curvas que, segundo Silveira (1994, p.29), representavam a ação das diferentes cores sobre as três categorias de fibrilas nervosas (cones) existentes na retina. Essas curvas foram divididas segundo as espécies de fibrilas. As pertencentes às primeiras espécies sensíveis à ação da luz vermelha apresentavam-se energicamente, as pertencentes à segunda espécie seriam muito sensíveis à ação da luz verde, e as fibrilas da terceira espécie seriam facilmente sensibilizadas pela luz azul.

O resultado da união dos conhecimentos desses dois grandes físicos, ainda de acordo com Silveira (1994, p.29), foi a demonstração de que era possível se obter qualquer cor do espectro através de uma mistura óptica aditiva, unindo-se as três cores básicas compostas pelas cores-luz: vermelho, verde e azul.

\subsubsection{James Clerk Maxwell (1831-1879)}

O físico escocês James Clerk Maxwell (1831-1879), além de complementar os estudos de Young e Helmholtz, com o método de redução das cores, teve uma grande importância ao relacionar os efeitos elétricos e magnéticos à luz.

No campo dos estudos dos processos tricromáticos, Maxwell foi o primeiro a determinar experimentalmente as funções de combinações de cores ou valores triestímulos para o espectro visível, reproduzindo em 1859 uma imagem em cores de 
síntese aditiva e foi o primeiro a medir e a definir o espectro (1860). Segundo Silveira (2002, p.30), Maxwell definiu que, para qualquer processo tricromático, deve-se inicialmente proceder a uma seleção de cores através da decomposição nas três cores primárias. As primárias instrumentais por ele definidas eram as radiações monocromáticas de comprimento de onda $631 \mathrm{~m} \mu$ (vermelho), $526 \mathrm{~m} \mu$ (verde) e $457 \mathrm{~m} \mu(\text { azul })^{1}$.

Mas talvez a maior contribuição de Maxwell no campo da cor como fonte luminosa se deva a suas pesquisas no campo eletromagnético. Segundo Salvetti (2008, p.70), foi no século XIX que Maxwell ao trabalhar com as equações que descrevem os fenômenos da eletricidade e do magnetismo pôde concluir que era possível obter equações de propagação de ondas no espaço vazio cuja velocidade era a mesma que a velocidade da luz. Maxwell também contribuiu com a verificação de que a informação elétrica viajava como onda transversal com a velocidade da luz no espaço vazio, deduzindo que a informação magnética fazia o mesmo.

A partir deste momento a ciência passou a tratar de maneira unificada os efeitos eletromagnéticos à luz, tornando assim compreensíveis os processos de produção, absorção e propagação da luz como um todo.

\subsection{Principais contribuições científicas para o uso da cor como fonte luminosa}

Os estudos, tratados e pesquisas feitos pelos autores citados anteriormente - Isaac Newton, Goethe, Thomas Young, Helmholtz e Maxwell - foram fundamentais para o desenvolvimento da ciência e do uso da cor como fonte luminosa. A compreensão de como o órgão visual humano capta e compreende a cor e a luz, formando a imagem, e o fato de se poder interpretar como a cor é vista pelo ser humano em geral, foi uma descoberta que só foi conhecida em sua totalidade a partir do século XIX. As respostas destas questões, envolvendo fisiologia e percepção, são importantes para os artistas das mídias digitais, que passam a ter em mãos ferramentas de pesquisa e análise já fundamentadas e comprovadas.

\footnotetext{
1 O milimícron $(\mathrm{m} \mu)$ é a unidade de medida utilizada nesta dissertação para fazer referência ao comprimento de onda. Será melhor exemplificada no capítulo seguinte ao se falar sobre radiação.
} 
A contribuição de Newton para os estudos da ciência e da óptica se desdobrou no conhecimento que hoje temos das propriedades da luz. A descoberta da luz como composição de cores viria a mudar o panorama da ciência, trazendo avanços tecnológicos e mudando a percepção do homem quanto à origem da cor. A experiência com os prismas revolucionara a concepção de síntese das cores em óptica. Newton contribuiu para a arte com os seus estudos cromáticos desenvolvendo o círculo das cores, que até os dias atuais é tomado como referência e é utilizado para representar percentualmente o valor que cada cor ocupa em todo o espectro. Newton estava interessado em divulgar e descobrir o lado técnico da cor e da luz e buscar sua origem da maneira mais exata possível, sem levar em conta a interferência do observador.

Goethe, por sua vez, estudou a fisiologia do olho humano, voltando-se mais para a psicologia e aprofundando o estudo da sensação e da percepção. De acordo com Silveira (1994, p.19), Goethe, ao tentar provar que a luz branca não é composta por nenhuma cor, acabou provando que a cor, por si só, era um fenômeno que escapava à física. A presença de Goethe e seu interesse pela cor abriram portas para o estudo fisiológico da cor, tornando os estudos que vieram a partir dele mais voltados aos efeitos da cor e não somente à causa.

Thomas Young colaborou com os estudos de fisiologia, inaugurando a Óptica Fisiológica. Desenvolveu em 1901 a teoria tricromática que, segundo Bouma (1947, p.207), dizia respeito à existência de três órgãos humanos sensíveis às cores vermelha, verde e azul e que, a partir da interação destas, era possível enxergar todas as cores do espectro.

Helmholtz deu continuidade aos estudos sobre a teoria tricromática de Young sob um caráter mais científico. Foi o primeiro, segundo Silveira (1994, p.28), a representar graficamente, através de curvas, as interferências que cada uma das três cores primárias faziam sob os cones, localizados na retina de cada indivíduo.

Thomas Young e Helmholtz contribuíram para dirigir os estudos da cor rumo à compreensão das relações cromáticas, por meio da análise e da descoberta do funcionamento dos olhos diante da luz. Definiram também um método de medida das cores. A teoria tricromática, inaugurada por Young e completada por Helmholtz, como 
relata Silveira (2002, p.28), é largamente utilizada nos dias atuais por pesquisadores e artistas que atuam no campo cromático. Os princípios de tal teoria são aplicados na produção e na reprodução de todas as cores na televisão, nos monitores e aparelhos digitais, e se baseia na existência de três tipos de receptores visuais destinados à captação das luzes coloridas: RGB (Red=vermelho, Green=verde e Blue=azul).

Outros cientistas viriam a complementar as teorias cromáticas e dar-lhes continuidade com base na cor como fonte luminosa. Edwald Hering (1834-1918), por exemplo, se opôs às idéias lançadas por Helmholtz e, segundo Silveira (2002, p.29), estabeleceu uma diferença existente entre as cores primárias percebidas, e as cores primárias que funcionam como estímulo. Para as cores como fonte luminosa, as determinantes pelo estímulo são as cores vermelho, verde e azul, e para as cores-pigmento opacas, são as cores vermelho, amarelo e azul. Mais tarde ficou provado que ambas as teorias de Helmholtz e de Hering se completavam, e que os processos na retina atuariam seguindo a teoria tricromática produzindo a sensação cromática. Já a teoria de Hering complementaria esta última afirmação, provando como se dá o processo de produção da percepção cromática.

O físico Maxwell (1831-1879) contribuiu para uma rápida evolução da tecnologia, após suas pesquisas no campo eletromagnético. Segundo Pedrosa (2008, p.109), a descoberta de Maxwell (1831-1879) está ainda na essência do colorido da televisão que, servindose de elementos computadorizados na criação e manipulação de imagens, desencadeou o atual império da virtualidade.

Em síntese, no panorama histórico aqui traçado, a busca por uma definição e pelas propriedades da cor sempre foi uma constante para os pesquisadores que se interessam por essa área. A formação de uma teoria da luz acabou se tornando complementar aos estudos da cor do objeto, e trouxe progresso aos experimentos tecnológicos dos dias atuais. 
Percebe-se, na seleção de teorias até aqui descritas, uma tendência a direcionar o estudo da cor no sentido de sua aplicação sob forma de luz. Foram estas grandes teorias, que hoje apontamos como marcos na história do estudo cromático que viriam a influenciar artistas e movimentos artísticos. Os artistas, influenciados por estes estudos e descobertas, que provocaram uma mudança na maneira de se compreender e "ver" a cor, tentariam por eles próprios "experimentar" e por meio de sua poética, dar à cor, um novo sentido, com base no que de mais recente tinha sido explorado pela ciência.

A cor, como fonte luminosa, passa a partir de agora a ser vista no cenário científico como propriedade física cuja relação com o homem é de fundamental importância. No campo das Novas Tecnologias da Comunicação (NTC), é patente a existência de determinadas experimentações que se viabilizam pela manipulação da cor materializada por fontes luminosas. Deste modo, quando articuladas poeticamente, podem favorecer o diálogo sinestésico entre obra e receptor.

A investigação dos aspectos fisiológicos, físicos, psicológicos e culturais, que serão apresentados no próximo capítulo, tentarão dar conta do desdobramento de múltiplas áreas no intuito de compreender a cor. Desta forma será possível analisar as propriedades da cor e sua articulação com o homem, que continuamente procura decifrá-la e dela se apropriar. 
"A luz é mediação. Os objetos do mundo aguardam inertes e latentes a sua manifestação, que só será possivel quando levados por feixes luminosos até os nossos olhos."

Modesto Farina 


\section{Capítulo 2}

\section{Da cor à luz}

A maneira como o estudo da cor será conduzido nesta pesquisa diz respeito à sua materialidade e potencialidade como um agente importante nos meios de comunicação. Para compreender a cor sob os sentidos que tangem a percepção será necessário nos concentrarmos em alguns de seus aspectos: fisiológico, físico, psicológico e cultural. Não iremos nos ater aos aspectos químicos da cor pois neste caso desviaríamos o estudo da cor como fonte luminosa para a cor como substância física, que engloba segundo PEDROSA (2009, p.98), o estudo da natureza e da organização dos átomos nas moléculas para determinar a cor percebida na substância. Tendo feito uma primeira abordagem dos aspectos da cor com ênfase na compreensão das propriedades básicas da cor como pigmento, a pesquisa será encaminhada para o estudo da cor como fonte luminosa, proposto por esta pesquisa, que nos conduzirá à compreensão do uso artificial da cor nos meios interativos das Novas Tecnologias da Comunicação (NTC).

O interesse em compreender os aspectos fisiológicos da cor se deve ao fato de querermos entender os fundamentos que elucidam como a cor é processada pelo homem, concentrando-se assim no problema de "como vemos" (BOUMA, 1947, p.20). A compreensão dos aspectos físicos se justifica pela necessidade de compreender "o que vemos" (BOUMA, 1947, p.20), ou seja, entender os processos físicos envolvidos quando a cor é exposta à determinada situação. Os estudos dos aspectos psicológicos e culturais da cor contribuirão para relacionar os efeitos que a cor pode causar no homem.

Todos esses aspectos se interrelacionam na prática do fazer artístico: fundem-se no processo criativo utilizado pelo artista, no momento em que lida com a cor. A forma de manipulação da cor é determinada pelo artista quando define seu objetivo e a concentração e forma de aplicação das cores. Deste modo, acredito que a melhor maneira de entender esse processo seria desdobrando os elementos constitutivos da cor e tratando-os isoladamente. Assim, será possível obter um material que condiz com pesquisas e teorias cromáticas: fundamentos para um estudo mais profundo da cor, visando compreendê-la não só como pigmento, mas principalmente como luz. 
A percepção da cor está estritamente ligada à visão e ao cérebro, conforme Guimarães (2000, p.20), tanto em seu sentido mecânico como emocional. O simples ato de perceber a cor envolve os quatro aspectos que serão apresentados neste capítulo: fisiológico, físico, psicológico e cultural.

Dependemos do bom funcionamento do órgão visual para perceber a cor sob todos os seus aspectos físicos. Nesta pesquisa não desviaremos nosso foco para nenhuma anomalia visual que venha a alterar a maneira como as cores são vistas, pois se assim o fizessemos, nos estenderiamos muito, correndo o risco de nos perder do foco principal proposto neste trabalho.

A visão é nossa principal ferramenta para discernir o mundo, de acordo com Santaella (1993, p.11), as pesquisas empíricas revelam que provavelmente devido a razões de especialização evolutiva, 75\% da percepção humana, no estágio atual da evolução, é visual. Os outros $20 \%$ são relativos à percepção sonora e os $5 \%$ restantes a todos os outros sentidos, ou seja, tato, olfato e paladar.

A potencialidade do ver e do ouvir foi favorecida com a criação de extensões artificiais capazes de lhes aumentar a acuidade. $\mathrm{Na}$ visão, por exemplo, temos os telescópios, microscópios, radares, etc. Com isso o homem acabou "treinando" e aprimorando mais este sentido em relação aos demais. Ainda segundo Santaella (1993, p.12), isso se deve ao fato de que os olhos e os ouvidos são órgãos ligados diretamente ao cérebro e, por isso, mais especializados, enquanto os outros sentidos são mais sensoriais e corporais.

Para Santaella (1993, p.13) a visão forma um aparelho biológico altamente especializado. Em linguagem técnica da comunicação, o olho não constitui apenas um canal para a transmissão de informações, mas é sim um verdadeiro órgão codificador e decodificador das informações emitidas e recebidas, de modo que parte da tarefa que seria de responsabilidade do cérebro, mas o processo já começaria a ser realizado nos olhos, para ser depois completado no cérebro. Seriam então os olhos e o cérebro complementares um do outro na produção da visão e do sentido da visão. 
Em decorrência dos princípios referidos por Santaella, a cor poderia ser definida como um sistema de informações e de signos visuais que carregam em si um significado e um sentido, que apenas após terem atravessado o órgão visual humano e atingido o cérebro poderão ser corretamente decodificados e traduzidos pelo receptor. No caso das artes visuais, o uso da cor na obra artística, quase sempre adquire um caráter bastante pessoal que descreve uma concordância com o núcleo de informações, que poderá ou não ser decodificada plenamente pelo receptor.

Em suma, ambas, visão e cor, caminham juntas. Precisam ser analisadas, ora em conjunto, ora isoladamente, a fim de compreendermos os efeitos e propriedades da visão e da cor, o que faremos nos próximos parágrafos. Não nos estenderemos em certas especificidades a que este estudo poderia nos levar, mas privilegiaremos a compreensão das propriedades cromáticas enquanto a base necessária para entender a cor como fonte luminosa, objetivo desta pesquisa.

\subsection{Aspectos fisiológicos da cor}

O estudo da cor em seus aspectos fisiológicos demanda uma investigação das funções orgânicas e dos processos realizados pelo órgão visual humano para que este possa reconhecer a cor em sua materialidade. É preciso entender o que ocorre desde o momento em que a cor atinge a retina, atravessa o nervo óptico, até ser decodificada pelo cérebro. Hoje a ciência já identificou o funcionamento do globo ocular e os processos de como a cor é interpretada pelo cérebro. Esse percurso se assemelha à percepção e às etapas que o homem segue ao identificar, associar e decodificar cada uma das cores.

De acordo com Guimarães (2000, p.19), a informação cromática, quando é emitida, ainda não constitui um signo. Ela deverá para isso ser recebida pela nossa visão e atualizada pela percepção e interpretação da materialidade cromática. Ainda segundo Guimarães (2000, p.20), é por meio do comportamento do aparelho óptico e do cérebro que alguns aspectos da cor são decodificados.

Antes de iniciar uma investigação sobre o órgão visual, cuja constituição é bastante complexa, é importante ressaltar que no tópico seguinte trataremos apenas os pontos indispensáveis para compreender a formação da cor pelo olho. 


\subsubsection{A percepção cromática nos órgãos visuais}

O olho, segundo Farina (2006, p.33), trabalha como uma câmara óptica composta por diversas lentes cuja função é a de convergir os raios luminosos, permitindo que sejam levados para a parede interna oposta ao orifício de recepção luminosa, captando a imagem. Essa analogia é bem representada na figura 5 na qual, Farina (2006, p.28) descreve que os olhos recebem a imagem das coisas exteriores em forma invertida, na retina; essa inversão mudaria automaticamente quando alcança o cérebro, através do nervo óptico, ficando assim endireitada a imagem no centro visual do cérebro.

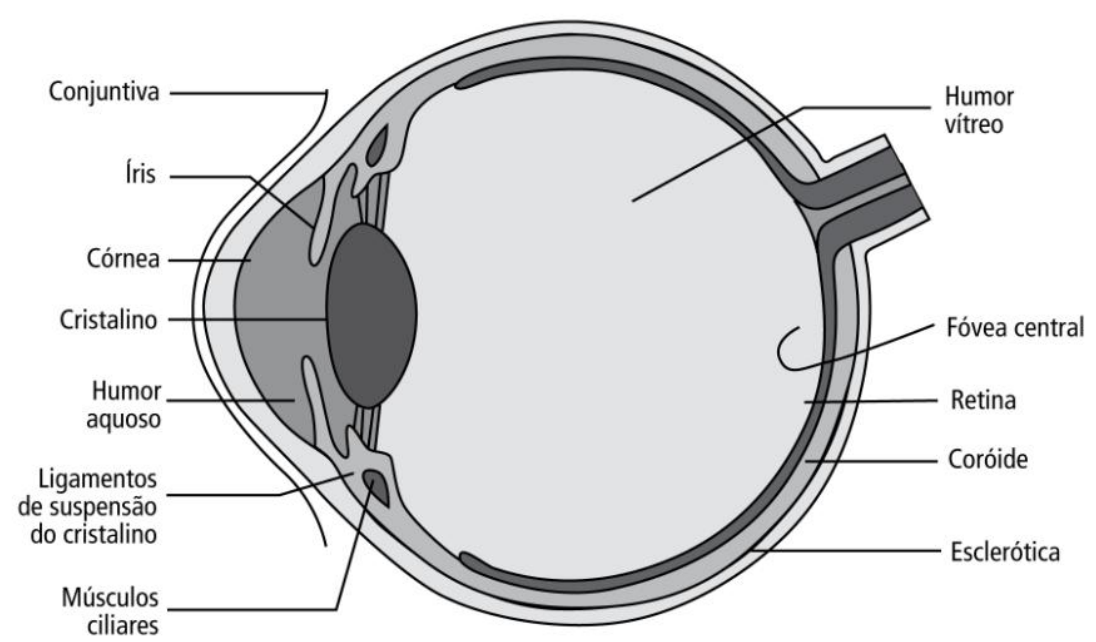

Figura 4: Anatomia ocular.

Fonte: Ilustração com base em Farina (2006, p.33)

Ao fazermos esta comparação dos olhos com uma câmera fotográfica, é necessário comparar o funcionamento dos dois. De acordo com Farina (2006, p.39), o olho, assim como a câmera, possui um sistema de lentes que são denominados córnea e retina; possui também um sistema de abertura variável, ou diafragma que seria a íris em nossos olhos e o filme que seria o equivalente ao papel da retina. No entanto, o autor salienta que, apesar de haver essa similaridade no processo de funcionamento da câmera e do órgão visual, existe um processo psíquico envolvido no funcionamento do aparelho óptico humano, que o diferencia da câmera. 


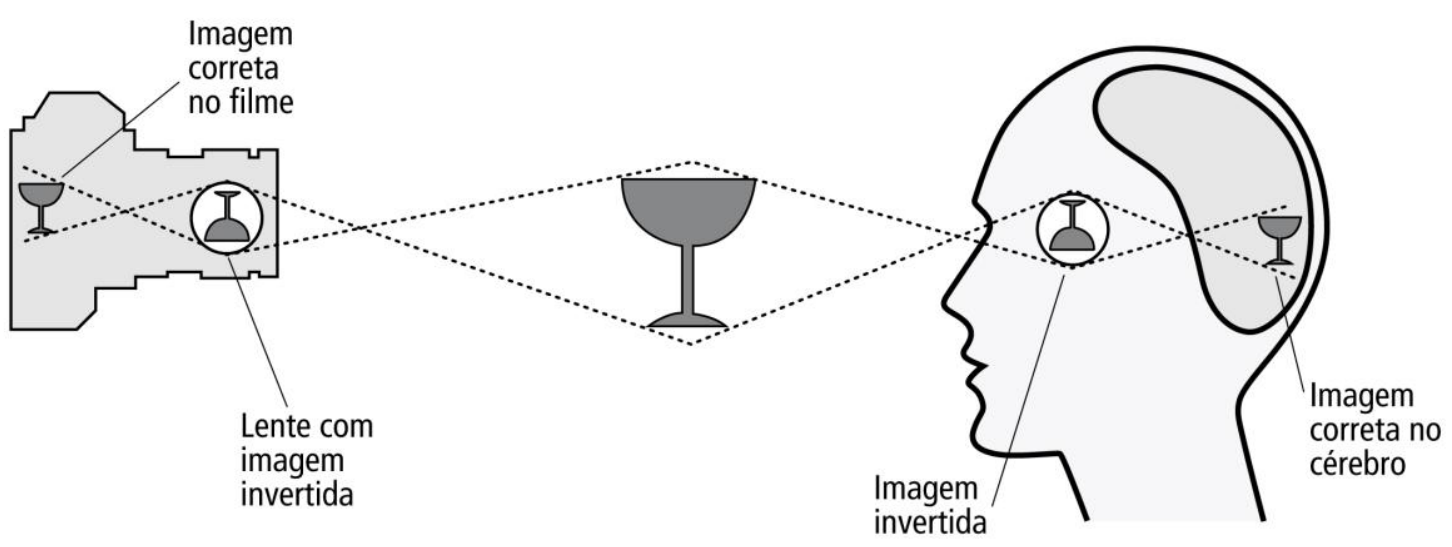

Figura 5: Equivalências.

Fonte: Ilustração baseada em Farina (2006, p.28)

Destacando o processo pelo qual fluxos luminosos formam a imagem invertida do campo visual, Guimarães (2000, p.23) apresenta o fato de que a imagem invertida é posteriormente endireitada pelo processo de cognição.

Vale também citar Marshall McLuhan, quanto à leitura sobre a inversão da imagem e seus efeitos no homem:

"Físicamente, aprendemos a endireitar a imagem visual do mundo traduzindo a impressão retínica do visual para o tátil e o cinético. Aparentemente, a posição normal é algo que podemos sentir, mas não podems ver diretamente." (MCLUHAN, 1974, p.217)

Essa "tradução de sentidos", que McLuhan (1974, p.217) apresenta ao referir o modo como a imagem invertida é endireitada por nós, é uma “indicação útil sobre as formas de atividade de distorção e tradução a que somos levados por qualquer forma de linguagem ou cultura”. Reforça-se, assim, a afirmação de que o que é visto depende dos aspectos fisiológicos, físicos, psicológicos, mas também culturais inerentes a cada receptor, como veremos ainda neste capítulo.

Passemos então agora a conhecer a estrutura do nosso órgão visual. $\mathrm{O}$ olho se posiciona na cavidade orbitária do crânio e possui uma estrutura bastante complexa. A fim de se apreender o processo da visão, faz-se necessário conhecer cada componente do órgão visual, e para isso citarei um longo trecho em que Farina (2006, p.33) descreve de maneira compreensível cada um dos principais elementos: 
Esclerótica: É a camada exterior do olho, cuja rigidez permite a este conservar sua forma.

Coróide: É a camada que se localiza depois da esclerótica, de fora para dentro, contendo inúmeros vasos sanguíneos.

Retina: Tem cerca de 130 milhões de células receptoras sensíveis à luz. É formada por diversas camadas de células, sendo as mais importantes os cones, os bastonetes e as células de ligação. [...]

Camada Pigmentada da retina: A melanina é um pigmento escuro existente na camada pigmentada da retina. Sua função é impedir que os raios luminosos sejam refletidos em todas as direções do globo ocular, causando difusa iluminação da retina sem o contraste de pontos claros e escuros, que são essenciais à formação de imagens exatas.

Córnea: Completa, na frente, a esclerótica (ou seja, é a continuação da própria esclerótica), fechando o globo ocular. É transparente devido à transformação histológica da esclerótica. Ela só permite que passem as ondas da magnitude de 300 a $1.500 \mathrm{~nm}$. [...]

Humor vítreo: É uma substância transparente e de consistência gelatinosa que enche o espaço situado entre o cristalino e a retina. Sua principal função é manter o globo ocular e a retina em seus lugares através de sua tensão.

Pálpebras: Ajudam a manter úmida a superfície do olho. Por seus movimentos de fechar e abrir protegem o olho contra a luz intensa ou a visão inesperada de algum objeto luminoso.

Cristalino: É formado por um tecido transparente e maleável. Seu papel é focalizar os raios luminosos quando penetram na córnea para formar a imagem na retina. Ele permite a passagem de ondas magnéticas de comprimento entre 380 e $760 \mathrm{~nm}$. [...]

Íris: A íris fica colocada diante do cristalino. É formada por um tecido pigmentado e exerce a função de diafragma, tendo a capacidade de regular a quantidade de luz que atinge a retina. [...]

Fóvea: É composto unicamente de cones e fica na retina, bem próxima do ponto de encontro de todas as fibras nervosas à saída da retina. Ela é sensível aos mínimos detalhes. Tem um diâmetro de quase $0,5 \mathrm{~mm}$.

Nervo Óptico: É formado de fibras neurais que vão da retina do olho até a área de projeção no córtex. A sensação fisiológica, na qual a retina transforma o estímulo físico, é levada ao cérebro pelo nervo óptico. [...] 


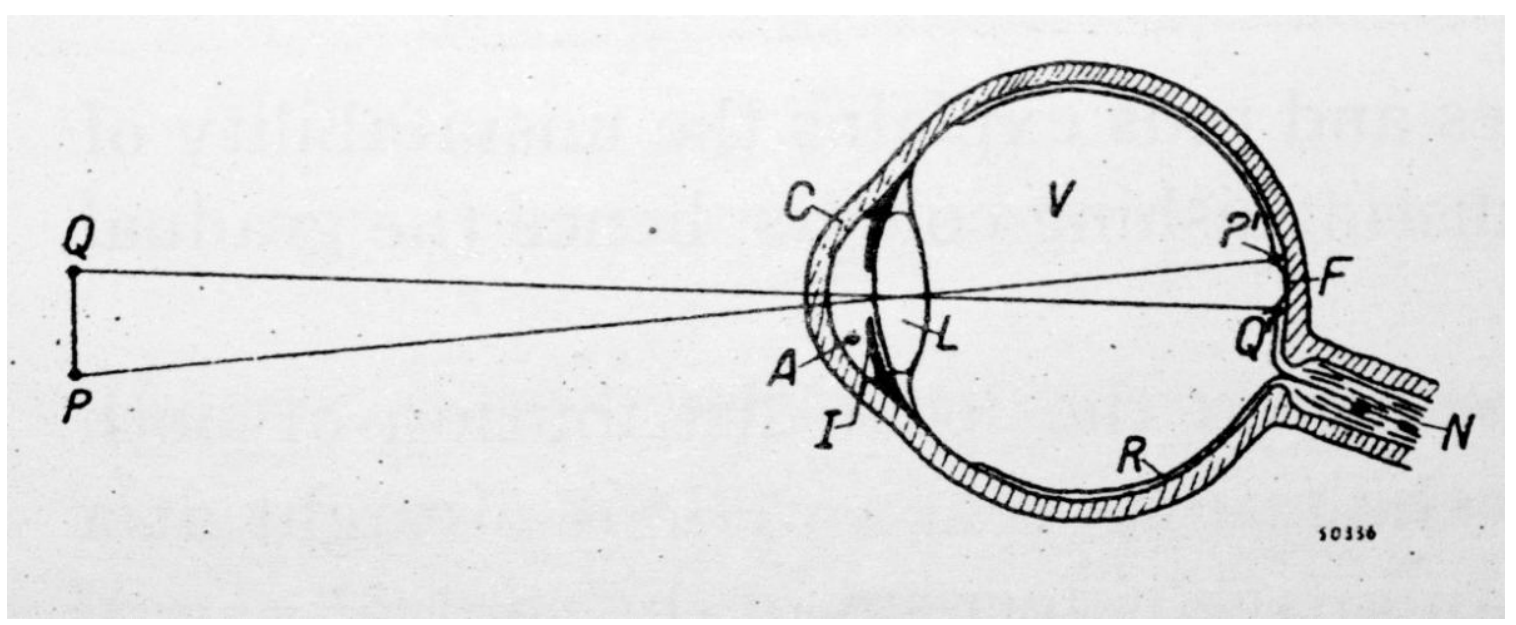

Figura 6: Gráfico esquemático do olho humano.

Fonte: (BOUMA, 1947, p.20)

Quem nos descreve de maneira bastante sintética o processo fisiológico pelo qual se dá a visão é Bouma (1947, p.20), em seu livro Physical aspects of colour. De acordo com o seu gráfico, visto anteriormente, Bouma explica que só enxergamos um objeto PQ devido aos feixes de luz que esse objeto reflete em direção à córnea $(\mathrm{C})$, na parte frontal do olho. O caminho que esse feixe percorre, uma vez ultrapassada a córnea, começa quando se atravessa o humor aquoso (A), as lentes do cristalino (L), o humor vítreo (V), até alcançar o fundo dos olhos na retina (R). É em razão dos vários planos curvos pelos quais esse feixe passou que é produzida uma imagem invertida no fundo do olho, da mesma forma como as lentes de uma câmera fotográfica, de acordo com o conceito introduzido anteriormente. A função que, em uma câmera, teriam as lentes para focalizar uma imagem, no olho é feito pelas lentes do cristalino (L). A regulagem da entrada de luz no olho é feita pela abertura e pelo fechamento da íris (I), tornando assim o diâmetro da pupila maior ou menor dependendo de cada situação.

Após esta primeira etapa, que Bouma (1947, p.21) classifica como um simples problema óptico no qual a luz atravessa o olho até alcançar a retina, começa um novo processo, no qual a retina precisa transformar a energia dessa luz incidente em outra forma adequada, para ser conduzida via estímulo (impulsos visuais) pelo nervo óptico até o cérebro. Ainda segundo Bouma (1947, p.21), a primeira fase dessa transformação é de natureza fotoquímica. Os vários elementos sensíveis à luz (cones e bastonetes) contêm substâncias que passam por mudanças químicas sob a influência da luz. Quando a iluminação cessa após um tempo elas retornam à sua condição original. Essas mudanças fotoquímicas são acompanhadas por uma liberação de energia sob a forma de 
energia elétrica. Essa energia liberada causa certos distúrbios de equilíbrio de natureza elétrica que são transportados através do nervo óptico $(\mathrm{N})$ e alcançam a parte do córtex (régio calcarina) destinada à assimilação de impressões visuais. Dá-se então lugar a uma comutação do estímulo introduzido pelo nervo em uma consciência da luz que permite a sensação da cor.

Tendo em vista o processo pelo qual a luz refletida pelo objeto alcança o córtex, para então se transformar na sensação da cor, é necessário focar a atenção de maneira mais detalhada nos elementos que constituem a retina. São esses elementos chamados cones e bastonetes os responsáveis por primeiramente registrar a cor e transmiti-la para o córtex. Bouma (1947, p.22) foi bastante claro ao descrever o funcionamento desses dois elementos. Segundo ele, os cones e os bastonetes se diferenciam em forma e função. Os bastonetes contêm uma substância sensitiva à luz chamada rodopsina, cujas propriedades fotoquímicas são conhecidas como muito acuradas. Já os cones não contêm a rodopsina. Bouma (1947, p.22) explica que quando o nível de iluminação é baixo, como no período noturno, apenas os bastonetes funcionam. Devido às suas propriedades, através deles enxergamos tudo em preto e branco. Mas quando se tem a presença de uma iluminação solar ou artificial, são os cones que funcionam, possibilitando assim a visão das cores. Outro fator importante, segundo Bouma, que diferencia os cones e os bastonetes diz respeito à localização desses elementos na retina. Ao olhar frontalmente para um pequeno objeto, uma imagem é formada na parte central da retina, chamada fóvea centralis $(\mathrm{F})$, cujo formato circular possui aproximadamente 0,25mm de diâmetro (a retina é levemente afundada nessa região). Na fóvea existem apenas cones, e em seu centro há uma área chamada mácula lútea, de aproximadamente $2 \mathrm{~mm}$, coberta suavemente por um pigmento amarelo. À medida que se desloca do centro da fóvea para a mácula lútea, o número de cones por centímetro quadrado decresce gradualmente dando lugar aos bastonetes, predominantes na periferia da retina.

Levando-se em conta os papéis desses dois elementos que convivem na retina é possível compreender melhor os aspectos da visão. Com a luz solar é muito mais fácil examinar de maneira acurada um objeto, pois para isso a fóvea entra em ação. Ao aproximarmos um objeto de nosso olho, nós o centralizamos na região da fóvea, que é onde estão concentrados em maior quantidade os cones. Quando a luz é escassa, os cones começam gradualmente a perder a função (dependendo da quantidade de luz que ainda se encontra 
no ambiente) e os objetos parecem perder a forma, a cor e a nitidez. Bouma (1947, p.23) explica que se olharmos para o céu e tentarmos fixar o olhar em uma estrela, podemos perdê-la de vista, mas se deslocarmos o nosso olhar dez graus de distância desta mesma estrela a imagem volta a aparecer.

No intuíto de compreender determinadas particularidades da visualização das cores pelos cones, é preciso esclarecer por que determinadas cores são mais ou menos "visíveis" a depender do posicionamento dos receptores (cones) na retina. Quem nos esclarece esta relação é Guimarães $(2000$, p.27) ao nos informar que a "distribuição das células sensíveis a cada cor determina áreas específicas de predominância”. Ainda de acordo com o autor "sabendo que o canal verde-vermelho é mais central que o azulamarelo, podemos dizer que as cores formadas pelo canal verde-vermelho são as mais bem percebidas à distância.”

Uma instalação interativa que aconteça ao ar livre e no período noturno, por exemplo, só seria visível e compreensível se a cor estivesse representada sob a forma de luz emitida ou projetada, evidenciando-se assim as cores em razão de sua localização em um ambiente escuro. Desse modo, durante a noite, quando a luz solar não está presente, as instalações interativas só conseguem ser vistas por utilizarem como fonte de iluminação a cor em forma de luz, recorte que será retomado no decorrer deste trabalho.

\subsubsection{O processo neurológico na visão cromática}

A visualização de qualquer cor pelo ser humano dependerá não somente dos órgãos visuais, como já foi visto, mas também da participação fundamental do cérebro que em sua estrutura desenvolve complexa tarefa no caminho do reconhecimento, sensação e seleção de cores pelo homem.

Antes de adentrarmos na compreensão da estrutura neurológica do ser humano é interessante mencionar, a partir de Farina (2006, p.32), uma citação do neuropsicólogo Richard L. Gregory, que diz "[...] o que os olhos fazem é alimentar o cérebro com informação codificada em atividade neural - cadeias de impulsos elétricos - a qual, pelo seu código e pelos padrões de atividades cerebral, representa objetos". A partir daí torna-se claro perceber a sintonia com que órgão visual e cérebro trabalham para que qualquer informação de fora seja corretamente decodificada. Todavia, a informação 
cromática, será decodificada segundo os padrões culturais de cada pessoa. É possível afirmar que a resposta do homem em relação à cor pode ser diferente em cada indivíduo mesmo que possuam a mesma estrutura fisiológica.

Um fator determinante também para que essa transmissão de informações ocorra corretamente é a presença da luz. Sabemos que o órgão visual humano é responsável por transmitir as informações do ambiente externo de modo a gerar a compreensão dos fenômenos até o cérebro. Esse processo acontece quando a luz está presente. Sem ela, nenhuma informação visual será traduzida pelo cérebro. Mas mesmo em um ambiente escuro, o homem pode imaginar a cor que quiser. Nesse caso, a cor independeria dos olhos, uma vez que se conhece aquela matiz.

\section{A estrutura neurológica}

No estudo da estrutura neurológica do ser humano, tomamos como referência as informações compiladas no livro A cor como informação: a construção biofísica, linguística e cultural da simbologia das cores (2000), de Luciano Guimarães, e recentes estudos publicados no livro Light Vision Color (2005), de Arne Valberg.

As nossas funções fisiológicas tais como visão, audição e demais atividades motoras como a fala, por exemplo, são delicados processos neurológicos que, de acordo com Valberg (2005, p.383), estão localizados em estruturas cerebrais específicas e altamente organizadas. Essa descoberta, segundo o mesmo autor, só se tornou uma certeza tardiamente, no ano de 1930.

Hoje podemos classificar as áreas de que o cérebro humano é composto e também identificar a especialidade de cada uma delas no desempenho de funções que o homem realiza em seu dia-a-dia.

O autor Guimarães (2000, p. 40) esclarece-nos, de maneira bastante concisa, os componentes da estrutura neurológica e de suas sub-partes. De acordo com o autor, o sistema nervoso humano é composto pelo sistema nervoso central - composto pelo encéfalo e medula espinhal - e pelo sistema nervoso periférico - que assume a função de uma malha que sobre todo o corpo transmite informações sensoriais das periferias 
para a medula espinhal e emite informações motoras do sistema nervoso central para a periferia por meio de canais de entrada (fibras aferentes) e resposta (fibras eferentes).

O encéfalo está dividido em cérebro anterior (ou prosencéfalo ou neocórtex), formado pelo cérebro e diencéfalo; cérebro médio (o mesencéfalo); e cérebro posterior (ou robencéfalo), formado pelo cerebelo, ponte e bulbo. (GUIMARÃES, 2000, p.40).

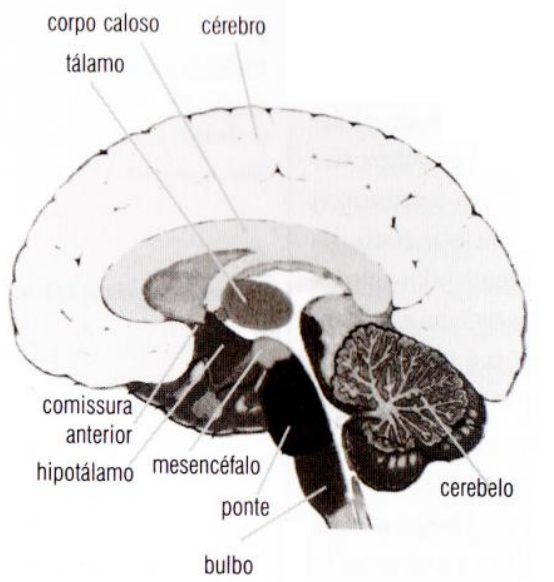

Figura 7: Vista medial do cérebro. Fonte: (GUIMARÃES, 2000, p.40)

De acordo com Guimarães (2000, p. 40), o conjunto total de tecidos do sistema nervoso é composto basicamente por dois tipos de células: as gliais, (ou células de suporte ou isolamento) e os neurônios que são unidades fundamentais do sistema nervoso e responsáveis pela transmissão de sinais.

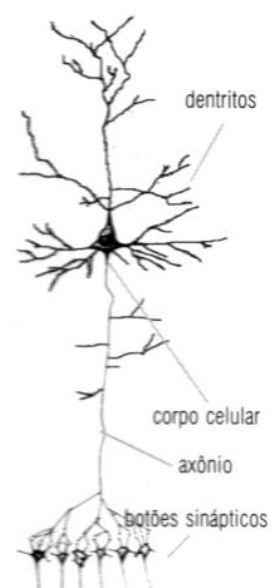

Figura 8: Estrutura de um neurônio. Fonte: (GUIMARÃES, 2000, p.41) 
O neurônio é formado, principalmente, por um corpo celular, cuja função é manter a vida da célula; detritos, as ramificações que recebem o sinal nervoso pelas sinapses (pontos de contato com outros neurônios); axônios, as fibras que conduzem o sinal até outro neurônio, músculo ou glândulas que serão ativados; e botão terminal ou sináptico, que envia sinais por sinapses ao liberar a substância transmissora no ponto de contato com outro neurônio. Os neurônios realizam dois tipos de sinapses, uma excitatória e outra inibitória (GUIMARÃES, 2000, p.41).

Complementando as informações sobre a funcionalidade dos neurônios, Valberg (2005, p.384) reitera que os neurônios são agrupados em áreas interconectadas levando-se em conta para isso o papel em comum entre eles.

O cérebro que faz parte do encéfalo é formado por dois hemisférios que, de acordo com Guimarães (2000, p.41), são interligados por fibras nervosas. Essas fibras nervosas - o corpo caloso e a comissura anterior - são os principais conjuntos de fibras pelos quais os dois hemisférios se comunicam, sem esse elo os dois hemisférios atuariam como sistemas independentes.

O córtex, ainda segundo o autor, é a camada superficial do cérebro onde o pensamento é processado e armazenado. Os neurônios nele se agrupam formando colunas verticais e em camadas superpostas com características e potenciais sinápticos diferentes.

A existência da estrutura de superfície irregular do córtex, marcada por dobras, alem de triplicar a sua área, colaborou na nomeação de áreas funcionais do cérebro. As depressões menores e menos profundas foram chamadas de sulcos e as maiores e mais profundas de fissuras; do encontro de sulcos e fissuras, algumas áreas anatômicas, ou lobos cerebrais, foram definidas: lobo frontal, lobo parietal, lobo occipital, lobo temporal. (GUIMARÃES, 2000, p.4142). 

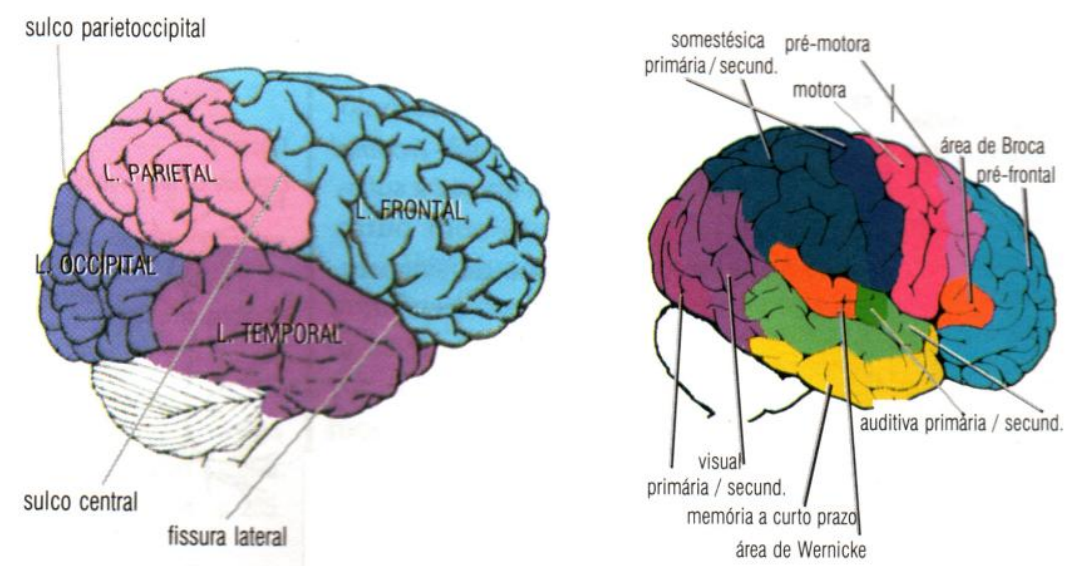

Figura 9: Os lobos do cérebro e suas áreas especializadas.

Fonte: (GUIMARÃES, 2000, p.41)

Com base em Valberg (2005, p. 384), cerca de 1/3 da área do córtex fica escondido nas reentrâncias e sulcos e em sua superfície armazena cerca de $10^{11}$ neurônios com aproximadamente $10^{15}$ botões sinápticos e mais de $3.000 \mathrm{~km}$ de nervos.

Guimarães (2000, p.42) nos esclarece que, de uma maneira geral, cada área do cérebro é especializada em um tipo de informação, conforme os fluxos de estímulos que recebe pelos feixes nervosos. De acordo com o autor, no lobo frontal as principais são a área pré-frontal, responsável pela elaboração do pensamento e pelas funções emocionais; a área motora, dividida em córtex motor (responsável pelos movimentos do corpo), córtex pré-motor (coordena os movimentos aprendidos) e área de broca que coordena os movimentos para a produção da fala). No lobo parietal está a área sensorial somestésica, cuja função é receber as sensações de todo o corpo recebendo e emitindo sinais em suas áreas primárias e secundárias. No lobo occipital a área visual primária que identifica luminosidade, cores, posição e contorno e, secundária, a que interpreta as informações visuais e as palavras escritas. No lobo temporal existe a área auditiva que, como as anteriores, também é dividida em primária e secundária. Em sua parte primária ocorre a identificação de características dos sons e na parte secundária a interpretação das palavras ouvidas, conferindo significação aos sons. Ainda seguindo a mesma ordem citada pelo autor, chegamos na área responsável pela memória a curto prazo e a área de Wernicke também situadas no lobo temporal. Na área de Wernicke, os sinais dos três lobos se encontram, possibilitando uma significação feral e cruzada das informações visuais, auditivas e somestésicas. 


\title{
A construção da imagem e da cor
}

Uma vez esclarecido como é constituída a estrutura cerebral e tendo sido esclarecidas as funções de cada elemento que a compõem, torna-se possível entender melhor como é feita a construção neurológica da imagem. Prosseguiremos fazendo referência ao autor Luciano Guimarães que soube, de maneira simplificada e precisa, reunir informações que descrevem o processamento da imagem e da cor pelos mecanismos neurológicos do ser humano.

\begin{abstract}
“A cor é o produto cerebral da sensação e do estímulo, produzida pelas radiações luminosas, sejam diretas ou refletidas, difusas ou transmitidas por um corpo como fonte de luz. A luz age como objetofísico-estímulo sobre o olho como canal receptor-decifrador do fluxo luminoso. O fenômeno da cor é, pois, um processo de percepção neurofisiológico que envolve o sistema nervoso e o aparelho fisiológico da visão. Esse aparelho decompõe a luz, seleciona-a e faz síntese, notadamente na área central da retina." (PLAZA, 1986, p.133)
\end{abstract}

O processo da visão, quando percebemos um objeto e, a ele aferimos uma significação, é um processo que se inicia na retina sob uma forma de função sensorial do sistema nervoso. Simultaneamente a ela ocorre a função motora do sistema nervoso, que é a intenção seletiva da imagem. A construção final da imagem só irá acontecer com a função integrativa do sistema nervoso, pois somente nesta fase é que a informação visual será processada, gerando significação através da interpretação de pensamentos e emoções. Portanto, segundo enfatiza Guimarães (2000, p.43), as três funções em conjunto coordenam as operações de seleção e interpretação que constituirão o objeto percebido como uma representação diferente do objeto físico. 


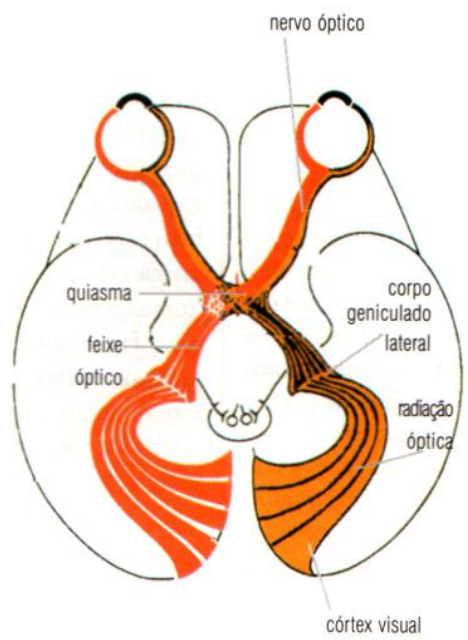

Figura 10: As vias do olho ao cérebro.

Fonte: (GUIMARÃES, 2000, p.43)

Devido à complexidade do processo envolvendo o caminho feito pela informação visual até seu processamento pelos olhos, optou-se por acrescentar extensa citação de autoria de Luciano Guimarães (2000) no intuito de apresentar melhor este percurso sem que se perca nenhuma informação:

Dos olhos, a informação visual segue pelos nervos ópticos que se cruzam no centro do crânio, no quiasma. Ali, os feixes originados na metade esquerda da retina de cada olho se juntam formando o feixe óptico que segue em direção ao hemisfério esquerdo do cérebro, onde fazem sinapse no corpo geniculado lateral (no tálamo) e formam a radiação óptica que conduz a informação para o córtex visual primário do hemisfério esquerdo. Da mesma forma, os feixes originados na metade direita da retina de cada olho conduzem a imagem ao córtex visual primário do hemisfério direito. Como as imagens são projetadas invertidas na retina, cada metade do campo visual será projetada no centro visual oposto: o hemicampo visual direito no centro visual esquerdo e o hemicampo visual esquerdo no centro visual direito. (...)

O corpo geniculado lateral recebe os sinais do hemicampo correspondente de cada olho e os mantém separados, embora em camadas superpostas de neurônios. É no córtex visual que essas informações, que são um pouco diferentes, visto que cada olho vê só um ângulo diferente, serão comparadas e interpretadas. Por meio de canais inibitórios provenientes do córtex visual primário e do mesencéfalo, o corpo geniculado lateral também controla a quantidade de sinais que segue ao córtex; portanto, também exerce função seletiva ou censora. Segundo Eccles, cada estação de conexão "permite a modificação do código das 'mensagens' dos órgãos receptores". 
Há uma correspondência entre as áreas da retina e as áreas do córtex visual primário. Para cada área do campo visual direito corresponderá uma área do córtex visual esquerdo e vice-versa. Quanto mais central for a imagem, mais próximos do pólo do córtex visual primário serão os sinais enviados. A área polar, denominada mácula, recebe os sinais provenientes da fóvea retiniada. Como se trata de uma área onde a acuidade visual é maior, a mácula é proporcionalmente maior que as áreas que recebem os sinais periféricos da retina.

Como a imagem projetada na retina é invertida, a imagem da área superior do campo visual é transmitida para a área inferior do córtex visual primário e vice-versa. A área inferior do córtex visual primário está mais próxima da área para cor e detalhes; esta disposição funcional indica que a área superior de um campo visual é mais propícia ao uso da cor, que requer percepção e resposta imediatas (GUIMARÃES, 2000, p.44).

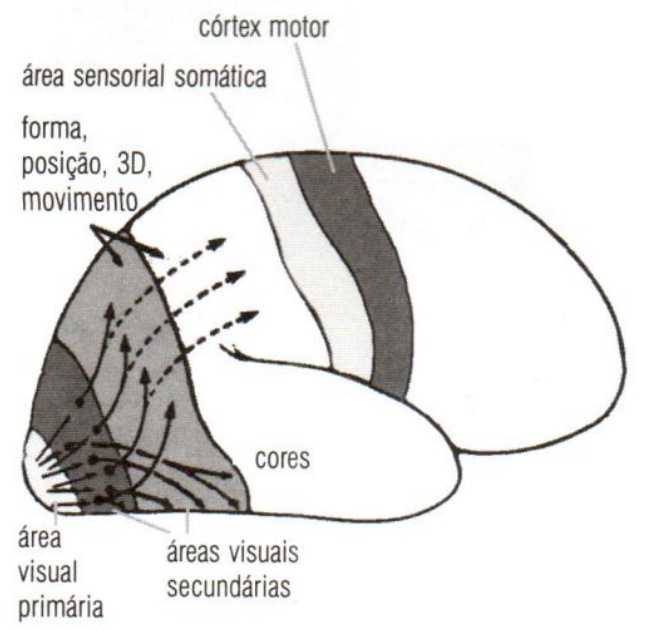

Figura 11: Transmissão dos sinais visuais. Fonte: (GUIMARÃES, 2000, p.44)

Os sinais recebidos pela área visual primária são enviados para as áreas visuais secundárias, para a parte superior do lobo occipital e daí para a fronteira com a área secundária das sensações somestésicas, de onde surgem as interpretações das formas, posição, profundidade e movimento. São enviadas também para regiões inferiores do lobo occipital onde o detalhamento das imagens (textura, superfícies) e as cores são tornados conscientes, além da identificação das letras e consciência do objeto. Nessa área há ligação direta com o sistema límbico, segundo Eccles, importante pela participação do conteúdo emocional (GUIMARÃES, 2000, p.44 - 45).

Em seu livro, Luciano Guimarães traça um panorama de como o processo de construção neurológico da cor desde o século XVII até os dias atuais era compreendido. Durante este período as descobertas se refinaram, corrigindo crenças que eram tidas como verdades. Foi o caso de Edwin Land que, em 1957, de acordo com Guimarães (2000, p. 
45), ao realizar experiências com filtros comprovou que a síntese da percepção das cores é global, não podendo ser ponto a ponto como era defendido pelos neurologistas do final do século XIX. Land com suas experiências tornou claro o fato de que uma área de cor percebida não pode ser classificada isoladamente dependendo para isso de uma visão global.

Segundo Varela, podemos notar a independência da cor percebida em relação à luz refletida localmente em dois fenômenos: a constância aproximada da cor, quando as cores percebidas permanecem relativamente constantes apesar de grandes modificações na iluminação; e o contraste de cores simultâneas ou indução cromática, quando áreas com colorações diversas interferem simultaneamente na percepção cromática: um mesmo verde, por exemplo, parecerá mais azulado quando estiver ao lado de um vermelho e mais amarelado ao lado de um violeta. Portanto, segundo Varela é preciso ter em conta os processos - complexos e compreendidos só parcialmente - de comparação cooperativa entre múltiplos conjuntos neuronais do cérebro, que designam cores aos objetos segundo os estados emergentes e globais que alcançam dada uma imagem retinal (GUIMARÃES, 2000, p.45-46).

O filósofo austríaco Ludwig Wittgenstein (1889-1951) chegou à mesma conclusão em sua obra Bemerkungen über die Farben (Anotações sobre as cores - 1950-51) ao perceber as diferentes formas que a cor branca poderia apresentar, dependendo de uma variação no ambiente que a circunda:

"Se eu digo de um papel que ele seja branco puro, e fosse disposta neve junto ao papel e este então parecesse cinza, com razão porém nomeá-lo-ia ainda branco em sua ambiência normal, e não cinzaclaro. Poderia ser que eu, talvez em laboratório, empregasse um conceito mais refinado de branco (como também por exemplo um conceito mais refinado da exata determinação do tempo)." (WITTGENSTEIN, 2009, p.25)

Outra visão de como a cor é detectada para uma interpretação completa de uma cena visual é feita por Guyton que, segundo Guimarães (2000, p.46), acredita que a cor é inicialmente percebida por meio dos contrastes de cores ${ }^{1}$. Nessa análise, atuam um processamento seriado das células simples às mais complexas - no qual vão sendo “decifrados progressivamente com mais detalhes" - e um processamento paralelo das

\footnotetext{
${ }^{1} \mathrm{O}$ contraste de cores é estudado a fundo pelo cientista Michel-Èugene Chevreul (1786-1889), que em 1839 publicou o tratado On the Law of Simultaneous Contrast of Colours (A lei dos contrastes simultâneos), onde investigou sistematicamente vários efeitos de cores umas sobre as outras. Será dada atenção aos seus estudos quando tratarmos ainda neste capítulo sobre a harmonia das cores.
} 
diversas informações da imagem em diferentes localizações cerebrais. Com a combinação de ambas as análises é possível proporcionar a interpretação completa de uma cena visual.

De acordo com Guimarães (2000, p.47), no caminho percorrido pelos impulsos visuais das áreas visuais secundárias para o sistema límbico, e do sistema límbico de volta para o córtex, a cor recebe seu estado emocional, - conforme a referência a Popper e Eccles -, e a percepção consciente da cor é modificada pelas emoções e sentimentos.

Segundo Eccles, podemos pensar no córtex pré-frontal como sendo a área em que toda informação emocional é sintetizada com as informações somestésicas, visual e auditiva, de forma a produzir experiências conscientes para o indivíduo e levá-lo a um comportamento apropriado. (GUIMARÃES, 2000, p.47).

$\mathrm{O}$ autor reitera que é nesse momento que encontramos algumas variantes nos códigos primários da percepção das cores, pois as projeções dos estímulos cromáticos para a área pré-frontal, hipotálamo e o sistema límbico completam a percepção consciente e emocional da cor e, dessa forma, um mesmo estímulo é interpretado de maneira variada por diferentes indivíduos.

\section{A relação entre os hemisférios cerebrais e as cores}

Cada hemisfério cerebral, segundo Guimarães (2000, p. 48), possui uma relativa autonomia e características diferentes de processamento de informação apesar de serem interligados e de possuírem uma intensa comunicação. $\mathrm{O}$ hemisfério denominado dominante é o esquerdo, onde opera o principal centro de linguagem e cálculo; e o hemisfério direito se responsabiliza pelas atividades espaciais, linguagem simples, compreensão e ideação não-verbal. Nas palavras desse mesmo autor "sendo a cor uma informação não verbal, cabe ao hemisfério direito a sua operação principal”.

Algumas áreas do lobo parietal no hemisfério dominante esquerdo, alem de serem consideradas áreas da fala, são também as áreas ligadas às associações entre dois tipos de estímulos, como, por exemplo, o tato e a visão. Logo, parte da construção final da cor também se deve ao hemisfério esquerdo (GUIMARÃES, 2000, p.49). 
Desta forma, conforme conclui o autor, a conexão entre os dois hemisférios permite a construção do conceito integral da cor, reunindo os dados da experiência exterior do hemisfério direito ao espaço da cor que é dado pelo hemisfério esquerdo.

Quando a informação cromática é recebida através de linguagem verbal, como exemplo a palavra vermelho, esta informação será decodificada pelo hemisfério esquerdo do cérebro que, segundo Guimarães (2000, p.50), lê a palavra vinculada à uma determinada cor e a encaminha para o hemisfério direito que reúne informações de ordem semântica, atribuindo significações como vermelho "cor de sangue" ou "cor quente".

Como o hemisfério direito justapõe ou compara percepções, a comunicação e a relação entre estas imagens armazenadas no hemisfério direito e entre os dois hemisférios, e ainda às informações trazidas pelos outros sentidos, conduzirão a interpretação pelos centros da linguagem, no hemisfério esquerdo, à proposição correta (GUIMARÃES, 2000, p.50).

Quando a informação cromática é recebida por uma linguagem não-verbal, tal como o autor exemplifica, o ato de acenar com um pano branco, implica uma recepção imediata pelo hemisfério direito que já busca o repertório da imagem, relacionando-a com "pedido de trégua (paz)", ou adeus ou qualquer outro significado armazenado de uso convencional entre o emissor e o receptor da informação visual. A informação então seguirá para o outro hemisfério (esquerdo), onde, conforme cita o autor, a sua gramática será aplicada e o "espaço" da cor no lenço será delimitado e a cor assim denominada.

\subsection{Aspectos físicos da cor}

Após compreender o processo fisiológico, pelo qual os olhos percebem a cor, o próximo passo é compreender a cor através de seus aspectos físicos. Este processo diz respeito as implicações físicas que se percebem no momento em que a luz atinge um objeto colorido ou, pelo mesmo, é emitida até ser identificada pelo olho humano.

Sabemos como o processo ocorre no interior do órgão visual e nas vias neurológicas, mas, para compreender o processo da visão cromática, como um todo, é necessário também entender a comunicação da cor por meio de suas diferentes radiações. Muitas dessas questões foram solucionadas pelos cientistas e pesquisadores que, por meio do estudo da física da cor, interessaram-se pelo que nossos olhos vêem. Neste sentido, 
muitas teorias foram escritas e muitas descobertas foram realizadas, permitindo-nos alcançar um patamar mais complexo da cor, que é a cor como fonte luminosa.

\subsubsection{Sistemas cromáticos / Classificação das cores}

Pedrosa (2009, p. 20) define cor como a sensação provocada pela ação da luz sobre o órgão da visão, sendo seu aparecimento condicionado à existência de dois elementos: a luz (objeto físico funcionando como estímulo) e o olho (aparelho receptor, funcionando como o decifrador do fluxo luminoso, decompondo-o ou alterando-o através da função seletora da retina - cone). E quando aqui se fala em órgão da visão - como elemento condicional para causar a sensação da cor - não se excluem os atributos das funções neurológicas que estão, na verdade, atreladas ao funcionamento dos olhos.

Ainda segundo Pedrosa (2009, p. 21), a percepção da cor é diferente da sensação da cor, pois a percepção existe apenas no campo físico (luz) e no campo fisiológico (olho). $\mathrm{Na}$ sensação existem, além desses aspectos, os dados psicológicos que alteram substancialmente o que se vê. Neste caso da sensação, soma-se, aos elementos de ordem física e fisiológica, o repertório cultural de cada indivíduo como integrante de uma sociedade. Portanto, podemos dizer que a sensação da cor nunca será a mesma para cada pessoa. No estudo que estamos fazendo dos aspectos físicos cromáticos, nos ateremos a investigar apenas os processos que promovem a percepção da cor, deixando os fatores psicológicos e culturais para os próximos ítens. A seguir, definimos as três características principais, correspondentes aos parâmetros de percepção básicos da cor: matiz, valor e croma.

Matiz: É o nome dado à cor que indica sua posição no espectro visível ou no círculo das cores. O matiz é determinado por um comprimento de onda específico da cor em um raio de luz. A descrição de um matiz pode ser feita com maior precisão quando comparada a uma outra cor (MORIOKA; STONE, 2006, p.12).
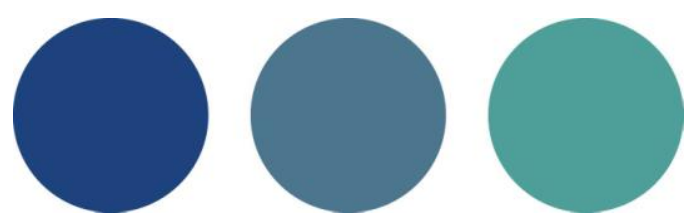

Figura 12: Gráfico que representa matiz.

Fonte: Gráfico de acordo com Morioka e Stone (2006, p.13) 
É o matiz que distingue o valor de uma cor em relação à outra de acordo com seu comprimento de onda: distingue azul, de verde; amarelo, de vermelho; violeta, de laranja, e assim por diante. Nesse exemplo a definição do matiz azul-esverdeado se torna mais fácil de distinguir por estarem as cores próximas lado a lado.

Valor: Refere-se à maior ou menor quantidade de luz numa cor. Valor é a intensidade luminosa de uma cor. Situa-se entre os extremos de branco e preto. Aos graus das escalas de valores, chamamos tons. Quando uma cor está escurecida, dizemos que é uma cor de tom baixo na escala de tonalidade (PLAZA, 1986, p.137).
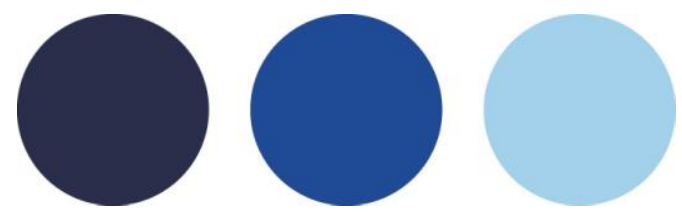

Figura 13: Gráfico que representa valor.

Fonte: Gráfico de acordo com Morioka e Stone (2006, p.13)

Percebe-se, no gráfico, que o valor da cor azul é alterado ao sofrer adição de preto (esquerda) ou adição do branco (direita). Dessa forma o azul se torna mais ou menos luminoso.

Croma (saturação ou pureza da cor): É a força da cor e é baseada numa escala que vai do cinza neutro até qualquer nível de cor (DANGER, 1973, p.18).
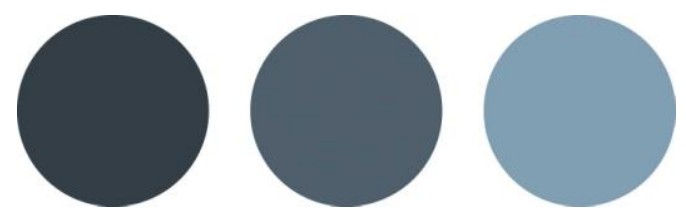

Figura 14: Gráfico que representa croma.

Fonte: Gráfico de acordo com Morioka e Stone (2006, p.13)

Nos softwares, para desenvolvimento de imagens gráficas, existem controles similares do uso da cor e que são conhecidos de modo geral como tom, brilho e saturação. Segundo Guimarães (2000, p.56), no computador o tom define a cor espectral de origem, tal como o matiz; o brilho (valor) define a atenuação ascendente, com o acréscimo de branco ou luz, bem como a atenuação descendente, mediante a subtração da luminosidade, ou o escurecimento progressivo da cor até o preto; e a saturação (croma), é utilizada para determinar a proximidade da cor espectral com a sua correspondente em uma escala de cinza. 
Além dos parâmetros básicos da cor: matiz, valor e croma, Pedrosa $(2009$, p.21) apontanos que a cor pode apresentar uma "infinidade" de outras variantes, geradas pelas particularidades dos estímulos que dizem respeito à percepção. Entende-se então que cada matiz corresponde a um ponto no espectro, como resultado de uma combinação de cores a partir da união de cores definidas como primárias. E a combinação das três cores primárias, em diferentes proporções, tem a capacidade de produzir um grande número de cores variantes, podendo chegar a 10 milhões (FARINA, 2006, p.57) com variação de indivíduo para indivíduo. Essas experiências visuais, ligadas diretamente à percepção da cor, foram detalhadas por Pedrosa na seguinte ordem:

Cor Geratriz ou Primária: É cada uma das três cores indecomponíveis que, misturadas em proporções variáveis, produzem todas as cores do espectro (PEDROSA, 2009, p.22).

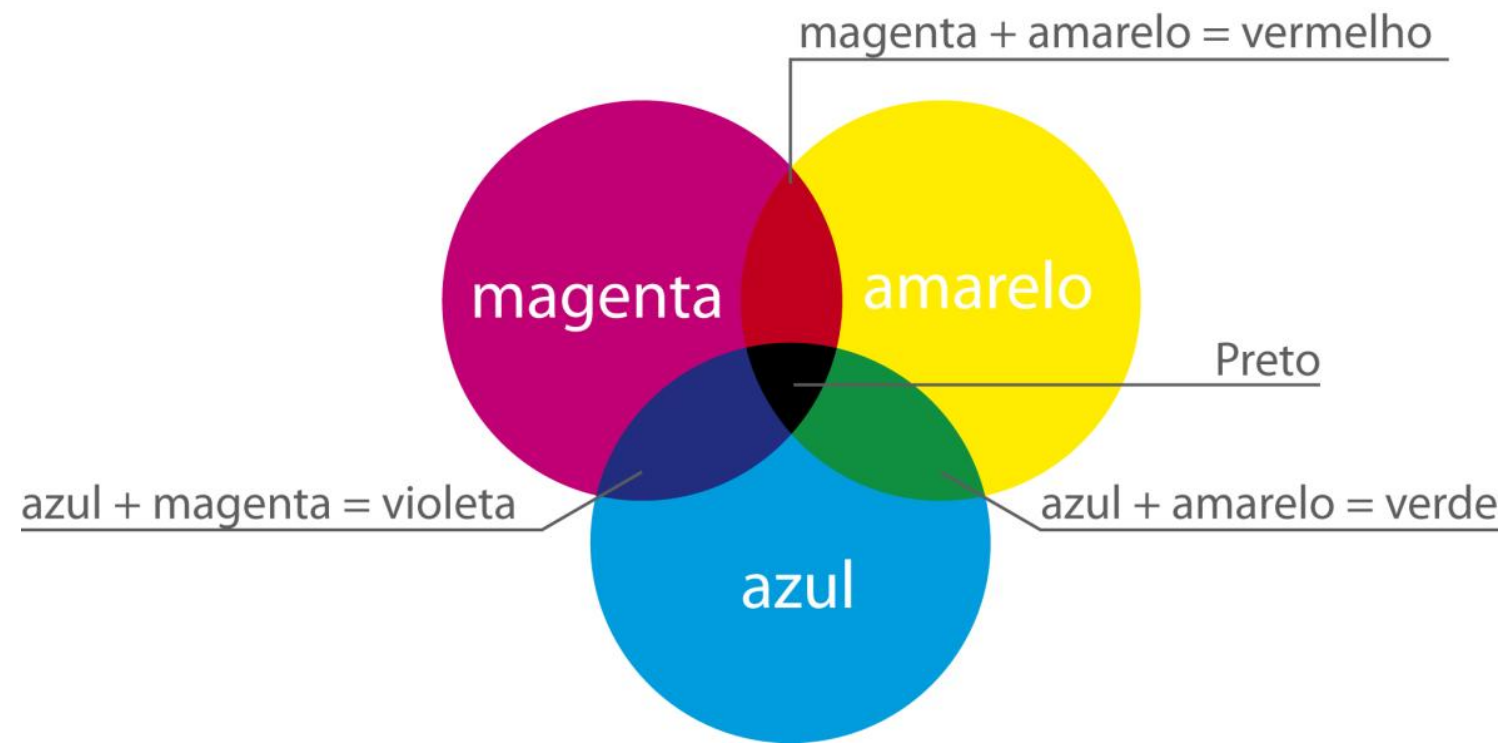

Figura 15: Gráfico que representa a mistura subtrativa das cores.

Fonte: Gráfico de acordo com Pedrosa (2009, p.23)

A mistura subtrativa se refere à mistura da cor-pigmento. A mistura das três cores produz o preto no fenômeno da "síntese subtrativa" (PEDROSA, 2009, p.22). Essas cores são utilizadas pelo artista quando trabalha com substâncias corantes transparentes (cores-pigmento). 
Nos programas gráficos de informática, esse sistema de cor-pigmento é de acordo com Guimarães (2003, p.194), registrada como CMYK: abreviação para Cyan (ciano), Magenta (magenta), Yellow (amarelo) e Black (preto). As cores de objeto podem assim ser expressas em porcentagens das mistura de CMYK como exemplifica o autor:
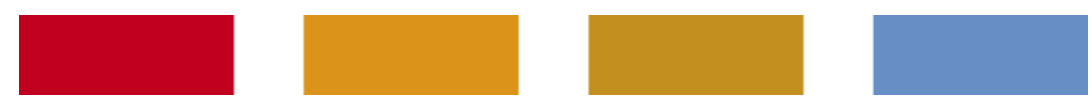

Figura 16: Modelos de cores que se baseiam no sistema CMYK. Fonte: Figura esquemática com base em Guimarães (2003, p.195)

"Este vermelho corresponde a $100 \%$ de magenta $+100 \%$ de amarelo. Este laranja corresponde a $100 \%$ de amarelo $+50 \%$ de magenta. Este ocre corresponde a $14 \%$ de ciano $+45 \%$ de magenta $+100 \%$ de amarelo $+5 \%$ de preto.

Este azul corresponde a $70 \%$ de ciano e $35 \%$ de magenta." (GUIMARÃES, 2003, p.194)

O sistema CMYK é linguagem padrão para a impressão de materiais gráficos, produzidos pelo computador. Neste trabalho, não nos aprofundaremos no sistema CMYK por não ter relação direta com nosso objetivo: a cor como fonte luminosa.

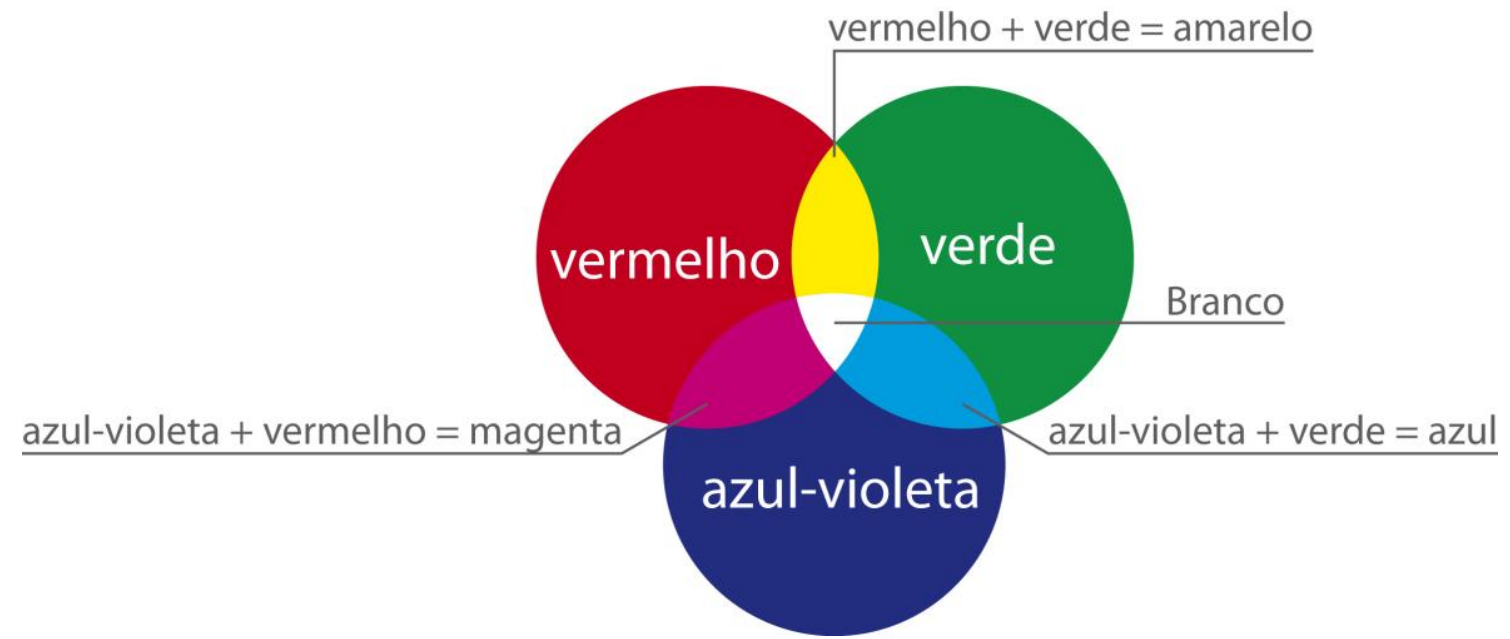

Figura 17: Gráfico que representa a mistura aditiva das cores. Fonte: Gráfico de acordo com Pedrosa (2009, p.23)

Ao se tratar do fenômeno da mescla aditiva, Farina (2006, p.79) relembra a experiência feita por Newton, na qual era possível recompor a luz branca, usando-se as cores do espectro solar. De modo a verificar tal experimento, pode-se girar rapidamente um disco no qual estão pintadas as cores do espectro. A princípio é possível perceber no disco rotacionado as três cores primárias, e, a seguir, com uma rotação mais rápida, perde-se de vista qualquer informação de cor, restando apenas o branco do disco. 
Farina (2006, p.79) explica que esse fenômeno acontece, pois as imagens se fixam na retina até que cesse o estímulo luminoso. Há então uma superposição de imagens que determina uma mescla, ou uma síntese, que resultará na sensação acromática branca. $\mathrm{O}$ mesmo efeito é alcançado numa experiência, narrada pelo autor que descreve o posicionamento de três refletores: um verde, outro vermelho e outro azul, num aposento escuro. Sobrepondo-se as três luzes emitidas, obtém-se a luz branca.

A mistura aditiva é utilizada pelos que trabalham com cor como fonte luminosa e são relativas aos receptores (cones) dos nossos olhos. De acordo com o que foi visto no capítulo anterior, foi Helmholtz (1821-1894) que, - ao completar a teoria da redução das cores a três básicas, de Thomas Young (1783-1829), - delimitou haver três espécies de fibrilas nervosas na retina: a vermelha (estimulada por ondas longas), a verde (estimulada por ondas médias) e a azul-violeta (estimulada por ondas curtas).

A mistura das três luzes produz o branco, denominando-se fenômeno "síntese aditiva" (PEDROSA, 2009, p.22). Essas cores são normalmente utilizadas pelo artista quando determina a cor por meio de um monitor num computador ou equipamento eletrônico nas mídias tecnológicas. As cores, como fonte luminosa, podem ser alcançadas tanto pela projeção, quanto pela emissão.

Por ser a mistura aditiva resultado da ação da cor como fonte luminosa, e por estar inserida no campo de pesquisa desta dissertação, daremos maior atenção aos efeitos ópticos da cor, artificialmente emitida/refletida. Assim, as cores básicas serão referidas como Vermelho, Verde e Azul, - correspondentes aos receptores (cones) de nossos olhos, - tal como no gráfico a seguir: 


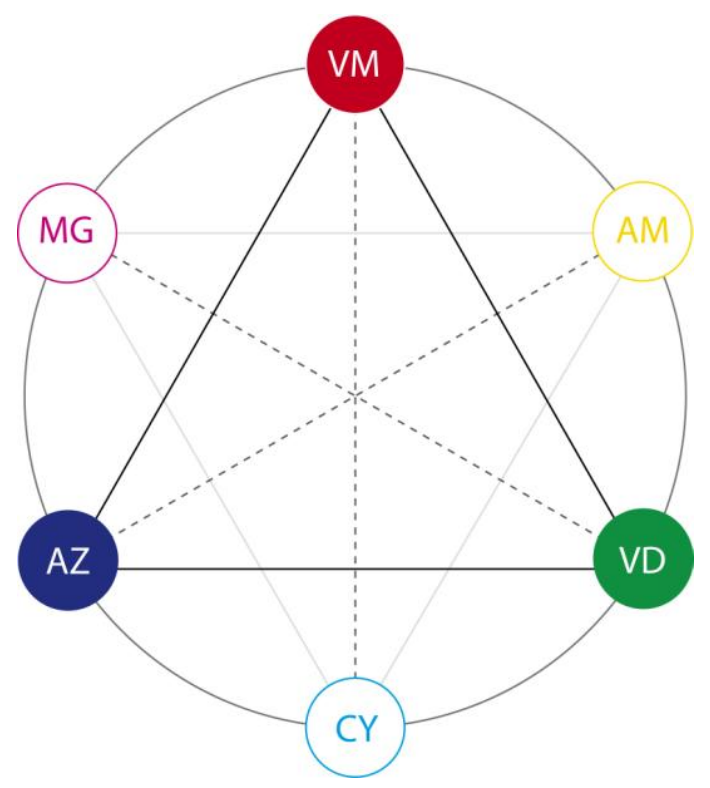

Figura 18: Gráfico que representa as cores primárias. Fonte: Gráfico baseado em Guimarães (2000, p.66)

As cores luminosas, por serem puras, possuem uma grande intensidade e brilho. São denominadas puras, porque ao contrário das misturas subtrativas, elas contêm todos os raios em sua composição, ao contrário da cor do objeto, que reflete parcialmente a luz, e, parte dela, é absorvida pelo objeto ${ }^{2}$. Como vimos no primeiro capítulo, foi a partir das experiências realizadas por Isaac Newton, que se conheceu o fato de a cor branca carregar, em sua composição, todas as demais cores do espectro. E, tal como vimos, Thomas Young, mais tarde, associou, a essa informação, que as cores derivam da percepção visual do espectro luminoso, e seriam relativas aos cones receptores de nossa visão, referentes às cores vermelho, verde e azul.

São vários os dipositivos que atuam a partir do funcionamento das cores primárias luminosas. Por exemplo, os aparelhos de televisão, os monitores de computador, que, de acordo com Guimarães (2003, p.195), são constituídos de "pontos (pixels), tripartidos com faixas de cada uma das cores-luz primárias."

\footnotetext{
${ }^{2}$ No que se refere à síntese de cores utilizadas em monitores (RGB), Guimarães (2003, p.197) nos esclarece que "uma das primeiras características técnicas é o fato de que muitas das cores que se obtêm em RGB não se conseguem em pigmentos: cores vivas e intensas na tela tornam-se opacas e com menos intensidade quando impressas".
} 
O sistema de cores de fonte luminosa é denominado de RGB nos recursos de projeção direta de imagens e, de acordo com Guimarães (2003, p.195), refere-se à abreviação de Red (vermelho), Green (verde) e Blue (azul). O autor exemplifica, a seguir, como as cores, como fonte luminosas, podem ser expressas em valores das misturas RGB que vão de 0 a 255:
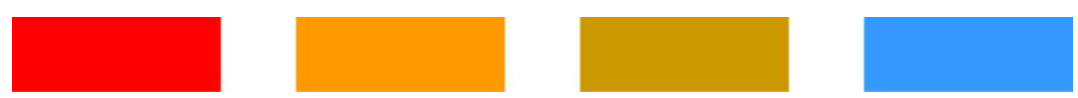

Figura 19: Modelos de cores que se baseiam no sistema RGB.

Fonte: Figura esquemática com base em Guimarães (2003, p.195)

"Este vermelho corresponde a $\mathrm{R}=255$.

Este laranja corresponde $\mathrm{R}=255+\mathrm{G}=153$.

Este ocre corresponde $R=204+G=153$.

Este azul corresponde a $\mathrm{R}=51+\mathrm{G}=153+\mathrm{B}=255$."

(GUIMARÃES, 2003, p.195)

Outra especificidade da síntese aditiva das cores, quando aplicada a monitores, é seu uso na Internet. De acordo com Guimarães (2003, p.197), ao "publicar na web, utilizamos a linguagem HTML (HyperText Markup Language)" essa linguagem especifica as cores em linguagem hexadecimal e é expressa em uma sequência de seis dígitos. O autor exemplifica os seguintes casos:
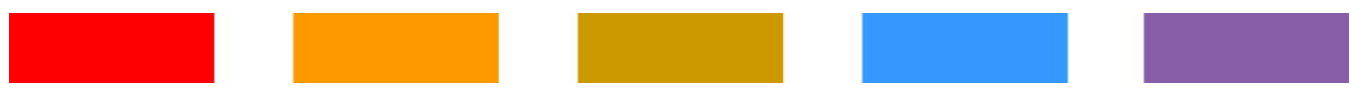

Figura 20: Modelos de cores que se baseiam no sistema HTML.

Fonte: Figura esquemática com base em Guimarães (2003, p.195)

"Este vermelho corresponde a FF,00,00

Este laranja corresponde a FF, 99,00

Este ocre corresponde a CC,99,00

Este azul corresponde a 33,99,FF

Este roxo corresponde a 87,5E,A8."

(GUIMARÃES, 2003, p.198)

Nesta linguagem, Guimarães (2003, p.198) elucida que "os dois primeiros dígitos correspondem à quantidade de vermelho; os dois seguintes, correspondem à quantidade de verde e, os dois últimos, à quantidade de azul.” 
De acordo com Guimarães (2003, p.198), computadores diferentes, com plataformas distintas (Macintosh ou PC, por exemplo) e com diferentes sistemas operacionais podem possuir calibrações de cores que não se equivalem e são percebidas nos monitores de formas variadas.

\begin{abstract}
"Normalmente, um monitor de um computador pessoal pode ter a capacidade de apresentar 16,7 milhões de cores ou ter a capacidade (ou estar apenas configurado) para apresentar até 256 cores. Isso se refere à profundidade de bits: 1 bit correspodente a 2 cores, 2 bits a 4 cores, 3 bits a 8 cores, 4 bits a 16 cores, 5 bits a 32 cores, 6 bits a 64 cores, 7 bits a 128 cores, 8 bits a 256 cores, 24 bits corresponde a 16,7 milhões de cores." (GUIMARÃES, 2003, p.198)
\end{abstract}

Outros dispositivos que manipulam em específico a luz colorida, serão tratados com maior profundidade nos anexos capítulo quando abordaremos a cor aplicada pelas Novas Tecnologias da Comunicação.

Cor Secundária: É a cor formada em equilíbrio óptico por duas cores primárias (PEDROSA, 2009, p.22).

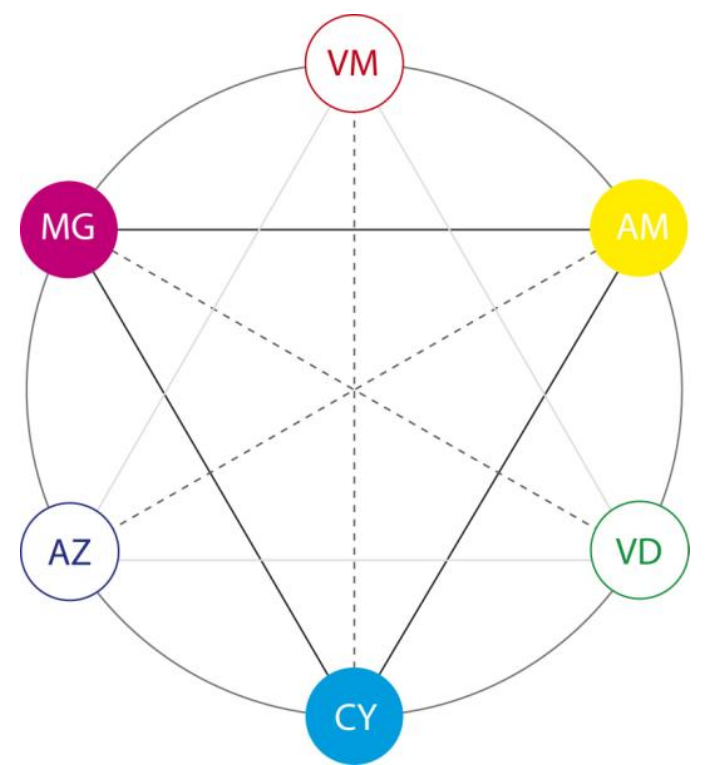

Figura 21: Gráfico que representa as cores secundárias. Fonte: Gráfico de acordo com Guimarães (2000, p.66)

As cores-luz secundárias são resultantes da soma de duas cores-luz primárias. São elas as luzes magenta (resultante da soma entre as luzes primárias azul e vermelho), amarelo (resultante da soma das luzes primárias vermelho e verde) e ciano (resultante da soma das luzes primárias azul e verde). Essas cores secundárias são relativas às cores primárias dos pigmentos transparentes, os mesmos utilizados nas impressoras. 
Cor Terciária: É a intermediária entre uma cor secundária e qualquer das duas primárias que lhe dão origem (PEDROSA, 2009, p.22).

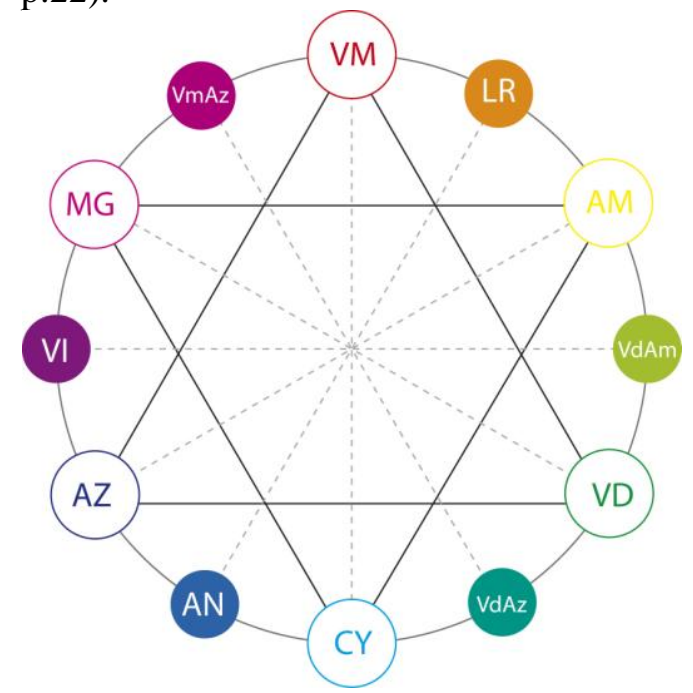

Figura 22: Gráfico que representa as cores terciárias.

Fonte: Gráfico de acordo com Guimarães (2000, p.66)

As cores-luz terciárias são obtidas pelo equilíbrio óptico de uma cor-luz primária com uma cor-luz secundária em iguais intensidades. De acordo com o gráfico, as cores-luz terciárias são: anil (ciano com azul), violeta (magenta com azul), vermelho-azulado (magenta com vermelho), laranja (amarelo com vermelho), verde-amarelado (amarelo com verde), verde-azulado (ciano com verde). Uma cor terciária é sempre complementar a outra cor terciária (oposta no círculo cromático) (GUIMARÃES, 2000, p.67).

Todos as classificações, que vimos, derivam do conceito do círculo das cores de Newton. Foi a partir dessa disposição circular que as cores primárias, secundárias e terciárias foram delimitadas com maior lógica, o que permitiu a realização de associações responsáveis pela identificação de padrões e harmonias.

Se analisarmos o círculo das cores, é possível notar como elas, a partir do vermelho, tendem a transmitir uma sensação de esfriamento à medida que chegamos ao violeta $\mathrm{e}$ magenta. E, nesse caso, diz-se sensação, pois foi, com essa base, que as cores foram classificadas em quentes ou frias, sem se levar em conta a percepção. Segundo Gage (1999, p.22), as cores parecem "quentes" ou "frias" apenas metaforicamente, uma vez que a radiação de cada cor indica fisicamente o oposto. Portanto, a cor violeta, considerada fria, situa-se em uma das extremidades do espectro e possui ondas curtas e 
energia de alta frequência com grande capacidade de aquecimento; já a cor vermelha, considerada quente, posiciona-se no outro extremo do espectro e possui ondas longas de baixa frequência, e uma baixa capacidade de aquecer.

Foi Charles Hayter o primeiro a apresentar sistematicamente as cores quentes e frias em círculo no ano de 1813. O gráfico, a seguir, feito por ele, representa a divisão das cores quentes e frias a partir da mistura subtrativa de pigmentos opacos.

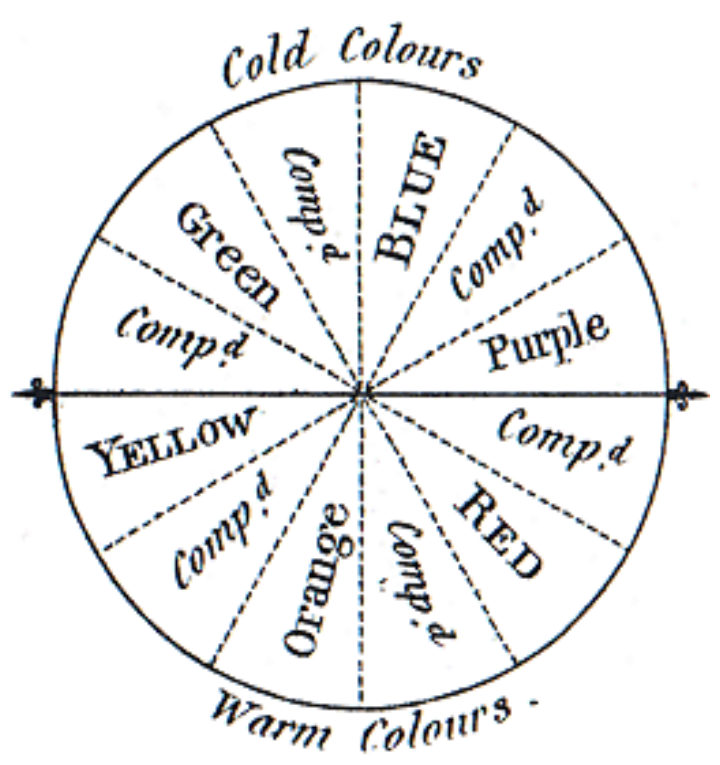

Figura 23: Gráfico das cores quentes e frias de Charles Hayter (1813). Fonte: (GAGE, 1999, p.23)

Segundo Barros (2007, p.304), Goethe também se dedicou à compreensão da divisão do círculo nas cores quentes e frias. Conforme foi esclarecido no primeiro capítulo, as pesquisas feitas por Goethe levavam em consideração os efeitos da cor no homem, e foi com essa base que ele determinou sensações atreladas aos dois pólos do círculo cromático:

"O lado negativo (passivo) do círculo cromático (que compreende as cores influenciadas pelo azul: azul, roxo, violeta) representa para Goethe sentimentos de nostalgia, ternura e inquietação (ao avermelharse, o azul torna-se mais inquietante). O lado positivo (ativo), onde encontramos amarelo, laranja e vermelho-alaranjado, despertaria para ele o nosso lado mais selvagem e ativo, pois tais cores são estimulantes e vivas.” BARROS (2007, p.304) 
Plaza (1986, p.137), complementa a visão de Goethe, e a partir de um ponto de vista fisiológico, preconiza que, por meio de uma resposta corporal, às cores, podemos classificá-las como frias e quentes. As que possuem ondas largas, como o lado vermelho do espectro, provocariam uma ativação sanguínea e um aumento do poder muscular. Por outro lado, o autor acrescenta que a "retina focaliza as cores quentes da mesma forma que focaliza os objetos próximos, e as cores frias do mesmo modo que os objetos distantes". Ainda, de acordo com o autor, as cores quentes seriam responsáveis por uma estimulação de caráter expansivo e saliente e, as frias, seriam responsáveis pelo relaxamento, tendo efeitos de profundidade de campo.

A partir de agora o fundamento como base para o presente estudo, será a classificação de cores quentes e frias, referida por Pedrosa (2008, p.113) que delimita as cores que transmitem a sensação de quente e frio em um círculo de cores luminosas, onde impera a mistura aditiva das cores. De acordo com o gráfico proposto por este autor as cores frias ocupariam 7/12 do círculo e as cores quentes ocupariam os 5/12 restantes.

Cores Quentes: De acordo com o círculo das 12 cores luminosas, são um total de cinco: vermelho-azulado, vermelho, laranja, amarelo e verde-amarelado.

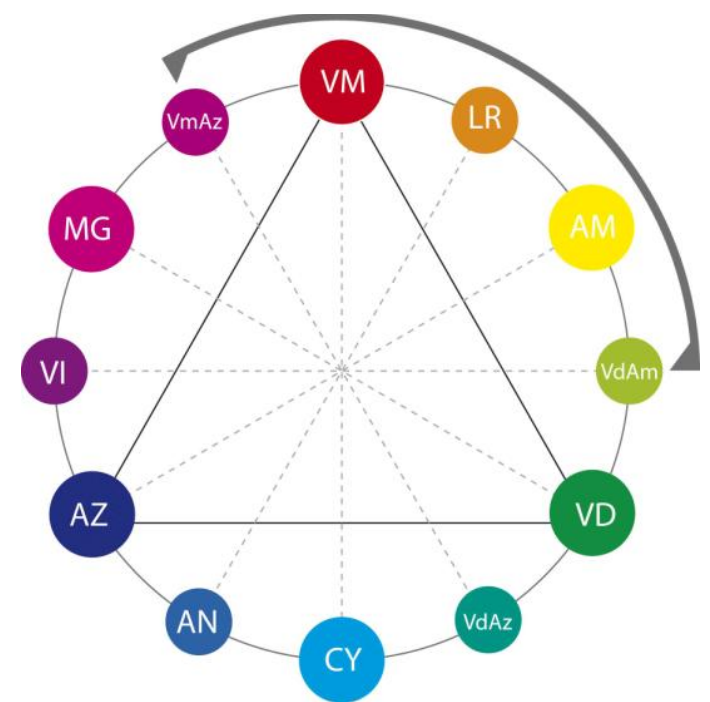

Figura 24: Gráfico que representa as cores quentes. Fonte: Gráfico de acordo com dados de Pedrosa (2008, p.113) 
Cores Frias: De acordo com o círculo das 12 cores-luz, são um total de sete: magenta, violeta, azul, anil, ciano, verde-azulado e verde.

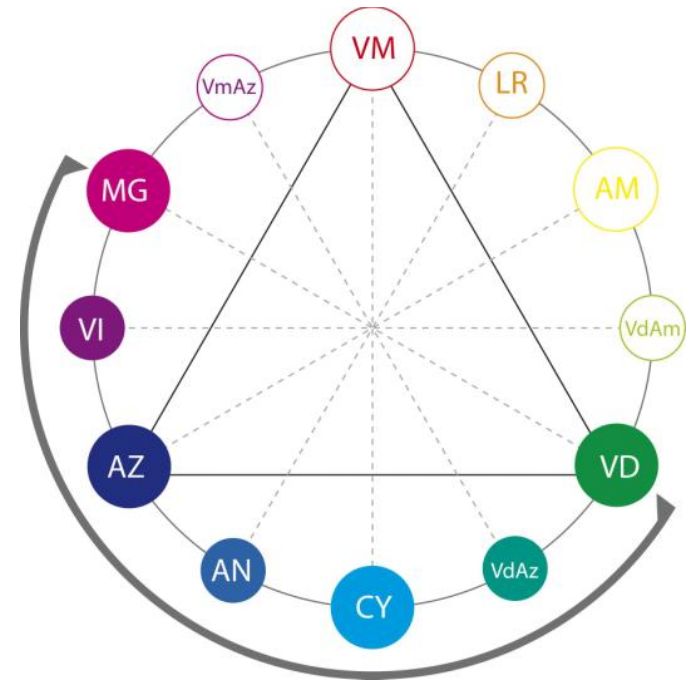

Figura 25: Gráfico que representa as cores frias.

Fonte: Gráfico de acordo com dados de Pedrosa (2008, p.113)

\subsubsection{Interações cromáticas}

Muitos pesquisadores buscaram, por meio de estudos e cálculos matemáticos, prever uma escala cromática que pudesse ditar a melhor maneira de se ordenar as cores. Essa tentativa de formalizar o relacionamento das cores, segundo Fraser e Banks (2007, p.38), data do tempo de Aristóteles (384 a.C.-322 a.C.), mas foi iniciada seriamente por Leonardo da Vinci (1452-15190) e progrediu com regularidade do séc. XVII em diante.

O círculo de Newton, conforme foi introduzido no primeiro capítulo, foi o primeiro a propor uma organização das cores, configurada em formato circular onde as cores opostas seriam complementares. Para Newton, segundo Morioka e Stone (2006, p.18), as cores opostas no círculo, somadas, produziriam uma cor neutra, ou "anônima". Tal como comentamos no capítulo anterior, o círculo das cores é formado pelas cores do espectro dispostas sob a forma circular e contínua.

O disco criado por Newton é dividido por raios em sete partes, correspondentes proporcionalmente às cores do espectro, com os seguintes graus: Vermelho: $60^{\circ} 45^{\prime} 34$ " / Laranja: $34^{\circ} 10^{\prime} 38^{\prime \prime}$ / Amarelo: $54^{\circ} 41^{\prime}$ 1" / Verde: $60^{\circ} 45^{\prime} 34^{\prime \prime}$ / Azul: $54^{\circ} 41^{\prime}$ 3" / Anil: $34^{\circ} 10^{\prime} 38^{\prime \prime}$ / Violeta: 60 45'34" (PEDROSA, 2009, p.61) 


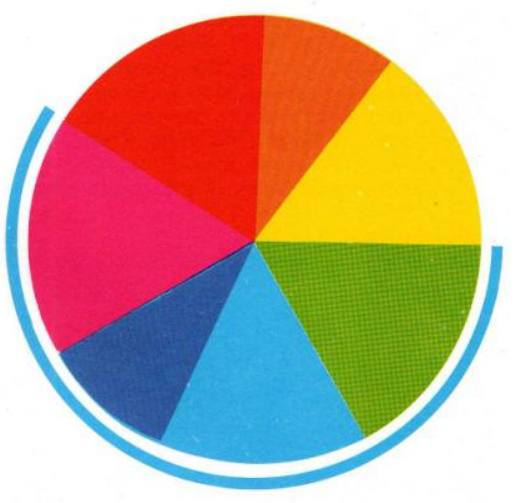

Figura 26: Círculo das cores de Newton.

Fonte: (PEDROSA, 2009, p.61)

Segundo Fraser e Banks (2007, p.38), a maior parte dos círculos cromáticos mostra apenas matizes puros, mas alguns acrescentam variações com brilho e saturação diferentes. No caso, quando se quer mostrar os três aspectos ao mesmo tempo, é necessário ter um diagrama tridimensional, o que torna tais sistemas difíceis de manejar.

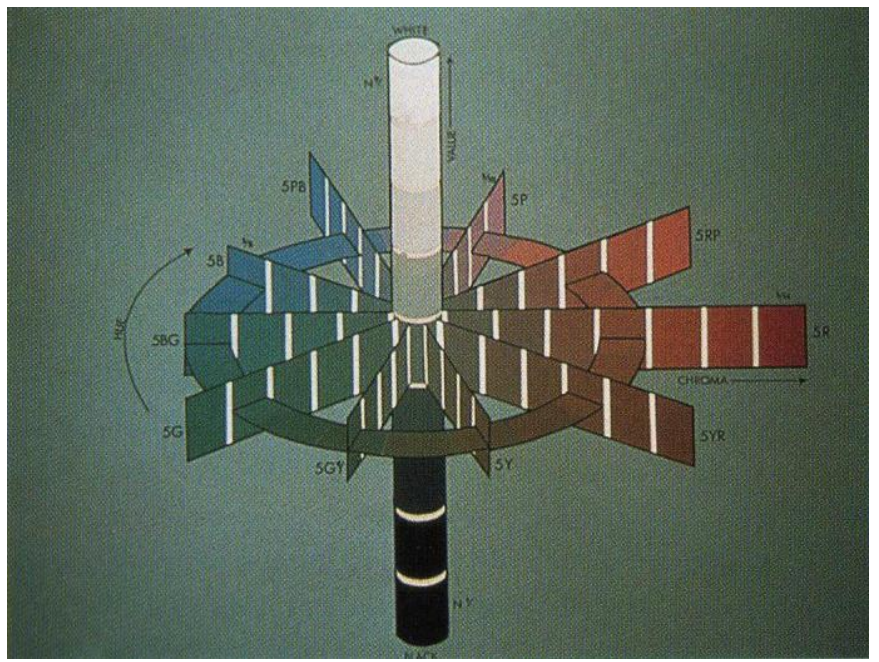

Figura 27: A árvore de Munsell. O círculo se estende verticalmente para produzir uma árvore de cores com brilho, variando de cima para baixo. As cores podem ser representadas como "ramos" que se irradiam do centro, em cada nível de brilho. Fonte: (FRASER; BANKS, 2007, p.46)

O artista americano Albert Munsell (1858-1918) criou um novo gráfico em três dimensões no qual se pode visualizar as matizes e suas relações de valor e croma. De acordo com o que nos descrevem Morioka e Stone (2006, p. 18), a importante contribuição de Munsell foi a descoberta de que alguns matizes, quando puros, são mais saturados que outros; então a relação das cores é distorcida quando apresentada em forma circular. O gráfico possui hastes que representam os matizes, e um eixo central que representa o valor, acrescentando-se branco ou preto ao matiz. Hoje esse formato de gráfico, chamado Munsell Tree (Árvore de Munsell) é largamente utilizado pela indústria americana como padrão de nomenclatura das cores, com influência sobre o CIE (Comissão Internacional de Iluminação). 
De acordo com Morioka e Stone (2006, p.20), uma relação harmônica das cores pode ser tanto feita com matizes próximos, acalmando os olhos, quanto com matizes contrastantes, excitando a visão. Mas o fator que prevalece em qualquer tipo de tentativa de se alcançar harmonia será sempre a preferência pessoal.

Para representar as combinações harmônicas foi utilizado o círculo de cores, que depois de ter sido proposto por Newton (1642 - 1727), contribuiu enormemente para o desenvolvimento da ciência e da arte.

Quando dispomos no círculo as cores, podemos nele perceber outras relações sistemáticas, diferentes das que indicam as cores primárias e secundárias. Uma destas relações é a de cores complementares, as cores que se posicionam em lados opostos no círculo a seguir:

Complementares: [...] Cada cor primária necessita da soma das duas outras primárias para completar a síntese, e a soma destas outras primárias dá origem a uma secundária. A primária e essa secundária são consideradas cores complementares (GUIMARÃES, 2000, p.67).

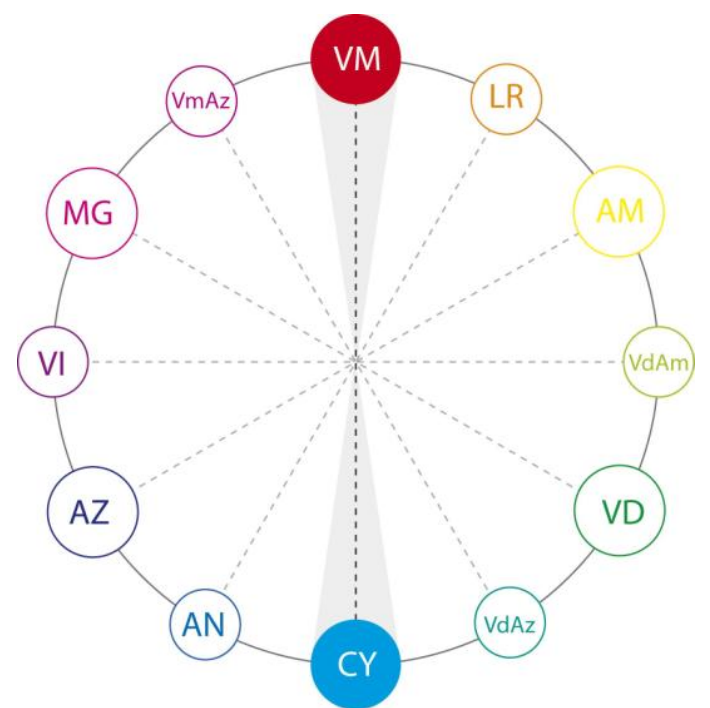

Figura 28: Gráfico que representa as cores complementares. Fonte: Gráfico de acordo com Morioka e Stone (2006, p.21) 
No caso das cores-luz primárias, a complementar de uma delas sempre será o resultado da fusão óptica das outras duas em igual intensidade. As cores complementares representarão sempre as combinações de maior contraste, causando grande vibração e excitamento aos olhos. A soma das cores luminosas complementares resultará sempre no branco.

"[...] a cor como qualidade em si, tal como é, atua em relatividade com os diversos matizes do repertório. É aí que ela tem seu desempenho máximo. A cor, então, não é a cor em si, mas é a cor relacionada com as outras, em conflito-atrito entre qualidades, no aqui-agora. "(PLAZA, 1986, p.133)

O complementarismo das cores, de acordo com Plaza (1986, p.136) é um fenômeno natural. A cor quando vista isolada pode representar algo oposto do que quando utilizada em contraste com outros matizes. Essa intensificação da mensagem que uma cor pode transmitir, quando simultaneamente posicionada em contraste com outra, pode ser comprovada no tratado escrito pelo quiímico orgânico Michel-Ėugene Chevreul (1786-1889) em 1839, entitulado On the Law of Simultaneous Contrast of Colours (Lei do Contraste Simultâneo das Cores). Nele, Chevreul apresenta um estudo sobre o efeito das cores contrastantes, quando apresentadas justapostas. Essa publicação derivou de um estudo que Chevreul, diretor da seção de tintas da fábrica Gobelins, fez enquanto assumia a função de regular as tinturas e também excluir, das linhas de lã, cores imprevistas e indesejadas.

Segundo Shapiro (2002, p.229), foi nessa época que pintores e artesãos queixaram-se de que os pretos que a empresa fornecia não eram escuros o bastante, pois tinham a aparência de fracos e cinzentos. O que Chevreul fez, então, foi pedir aos artistas que lhe fornecessem o que para eles seria considerado um bom preto. Ainda de acordo com a autora, Chevreul com esses materiais em mãos se pôs a analisá-los quimicamente e descobriu que um bom preto não era diferente, em substância, dos pretos imperfeitos. Assim, passou ao exame do contexto visual da cor. Observando que o preto insatisfatório era usado como um tom de sombra sobre uma forma azul ou violeta, foi levado a investigar o efeito da cor vizinha sobre o preto. Percebeu, portanto, que as cores vizinhas influenciavam a aparência umas das outras. Esse mesmo efeito já havia sido percebido por Aristóteles (Meteorologia) e Buffon (cores "acidentais" ou "fugitivas"). 
Assim como narra Shapiro (2002, p.229), Chevreul investigou sistematicamente vários efeitos de cores umas sobre as outras. Descreveu as reações de grande número de pares de cores e resumiu-as de maneira teleológica, contrariando a nossa tendência natural a ver cores vizinhas tão distintas quanto possível.

Esse mesmo efeito de interferência das cores tem como base, segundo nos aponta Barros (2007, p.88), o efeito da pós-imagem. A autora exemplifica o efeito, fazendo-nos perceber que, se fixarmos o olhar em um quadrado verde por cerca de um minuto, notaremos uma borda vermelha surgindo em seu entorno e, quando desviarmos o olhar para uma superfície branca, veremos a cor complementar vermelha.

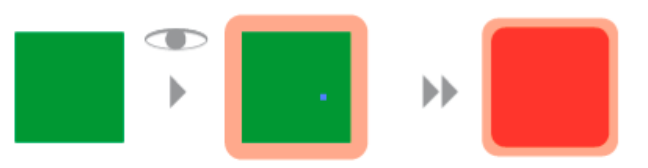

Figura 29: Efeito da pós-imagem.

Fonte: Ilustração de acordo com Barros (2006, p.88)

A explicação deste efeito, nas considerações de Barros (2007, p.89): quando estimulamos apenas um dos três receptores (cones), que temos presentes em nosso órgão visual, por um determinado tempo, ocorre uma espécie de saturação, que resulta na sensação de exergarmos a cor complementar à original.

Esse efeito explica o fato de que, quando temos duas cores complementares situadas lado a lado, o resultado de ambas é vibrante: a complementar de cada uma delas reforça a cor ao lado, que se torna ainda mais vibrante aos nossos olhos.

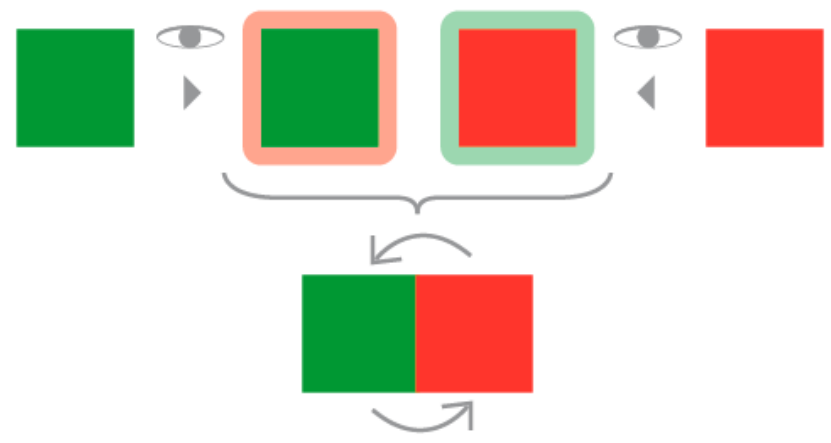

Figura 30: Contraste simultâneo em duas cores complementares.

Fonte: Ilustração de acordo com Barros (2007, p.91) 
Podemos aplicar este princípio de proximidade das cores em sinais luminosos como os pixels que, justapostos, às primárias: vermelho, verde e azul que em diferentes intensidades, podem representar um outro matiz e quando posicionadas em contraste com outra cor luminosa, podem manifestar um maior ou menor índice de harmonia.

Hoje em dia, nos diversos softwares gráficos voltados à imagem, a cor é controlada facilmente por meio de paletas com um espectro de matizes e controles para ajustar a saturação (croma) e a luminosidade (valor). Quem decide como e quanto ajustar os níveis de cor até alcançar a harmonia é o artista, ou o operador do software num processo individual de criatividade.

As porcentagens de luminosidade das cores, de acordo com PLAZA (1986, p.135), distribuídas conforme o gráfico a seguir, representam na prática os conceitos de mistura aditiva. Desta forma, se somarmos os valores percentuais correspondentes às cores primárias luminosas: vermelho $(22,2 \%)$, verde $(70,7 \%)$ e azul $(7,1 \%)$, obteremos como resultante o branco que equivale a $100 \%$ de luminosidade, ou seja, a soma de intensidade das três cores primárias. Esse gráfico explica de igual modo a formação das cores secundárias: amarelo, ciano e magenta. Se somarmos as porcentagens de duas cores primárias: vermelho $(22,2 \%)$ e verde $(70,7 \%)$, obteremos como resultante a cor secundária amarela $(92,9 \%)$. O preto, que na tabela é classificado como $0 \%$ de luminosidade, é formado consequentemente pela ausência de todas as cores.

\begin{tabular}{|l|r|}
\hline Branco & $100 \%$ \\
\hline Amarelo & $92,9 \%$ \\
\hline Cyan & $77,8 \%$ \\
\hline Verde & $70,7 \%$ \\
\hline Magenta & $29,3 \%$ \\
\hline Vermelho & $22,2 \%$ \\
\hline Azul & $7,1 \%$ \\
\hline Negro & $0,0 \%$ \\
\hline
\end{tabular}

Figura 31: Porcentagens de luminosidade. Fonte: (PLAZA, 1986, p.135) 
Tal gráfico nos facilita compreender o mecanismo dos dispositivos tecnológicos utilizados pelos artistas ao lidarem com a cor como fonte luminosa. O seu manuseio está intrínseco ao conhecimento dessas relações de luminosidade, podendo o artista obter um determinado matiz a partir da mistura aditiva das cores primárias e secundárias. Essa intervenção nos valores dos sinais luminosos é mais notada quando o artista das novas tecnologias manuseia dispositivos chamados diodos emissores de luz (LED) que usados de maneira conjunta, e em três cores primárias: o vermelho, o verde e o azul, podem os diodos variar cada qual em intensidade, obtendo-se diferentes matizes por mistura aditiva.

\subsubsection{A cor da luz e suas radiações}

A luz é radiação eletromagnética e um elemento indissociável da cor. Sem luz não se percebe a cor. A luz age como um estímulo físico ao olho (aparelho receptor), que funciona como decifrador do fluxo luminoso, decompondo-o ou alterando-o por meio da função seletora da retina.

Os fótons se disparam em todas as direções e a matéria modifica suas características e seus percursos, com o que nos oferece a possibilidade de decifrá-la. Por isso, podemos dizer que a luz é o veículo mais importante de informação do qual dispomos (TORNQUIST, 2008, p. 29).

Para compreender a cor é necessário percebê-la como um todo, como um conjunto de fatores de onde ela deriva. Para se investigar sua origem é necessário compreender que a cor nada é, sem a luz, pois, sem a luz, perdemos de vista qualquer sinal visual de uma determinada cor. E se, para ter a cor, é necessária a luz como fator reagente, considerase que a cor, em sua propriedade, é formada pela luz.

O entendimento pleno da relação entre a cor e a luz se deu, como foi citado no primeiro capítulo, a partir do final do século XVII. Desde esse período, marcado pelos experimentos na área da física feitos por Newton, passando pelos estudos empíricos de Goethe - onde o homem passou a ser inserido como parte fundamental desse relacionamento entre cor e luz - até os dias atuais essa relação foi se aperfeiçoando. $\mathrm{O}$ homem de hoje pode entender não só como a cor proveniente de fonte luminosa é processada mas também identificar particularidades, em seu organismo, inerentes aos seus aspectos físicos e psicológicos específicos. 
Como havíamos visto nos estudos pioneiros de Thomas Young, a cor só é visível devido ao fato de o ser humano ter a capacidade de discernir ondas de luz de diferentes comprimentos. Esse efeito é o causador da sensação cromática. A faixa de espectro visível para o homem compreende milhões de cores, a de maior comprimento de onda é a cor vermelha e, a de menor comprimento, a cor violeta.

A cor se deriva da luz, seja ela natural ou artificial. Com pouca luz, pouca ou nenhuma cor é presente. Com muita luz aparecem muitas cores. Uma luz forte produz uma cor intensa (MORIOKA; STONE, 2006, p. 10).

Desta forma, de acordo com o que foi investigado, a luz é radiação. E a cor uma transformação da luz, determinada por uma mistura de radiações simples. Essas radiações são classificadas segundo o seu comprimento de onda, que decresce imperceptivelmente do vermelho ao violeta. Com isso é possível comprovar que o elemento determinante para a manifestação da cor é a luz, pois sem ela não há radiação e consequentemente não identificaríamos a cor.

Farina (2006, p.57) lembra que as radiações consistem em vários tipos de vibração: ondas de rádio, infravermelha, visíveis, ultravioleta, gama e cósmicas. E nesse grande espectro, cientistas confirmam a formação de cerca de dez milhões de cores que invadem o campo visual humano. De todas essas cores, apenas três cores são recebidas por nossa retina através de nossos receptores (cones), e a fusão óptica dessas três cores reproduz todas as outras cores que podemos enxergar. Esse conhecimento se baseia nos estudos feitos por Thomas Young e Helmholtz de que resultou a teoria tricromática (1901).

A luz é onda eletromagnética e foi a partir dos estudos feitos por Maxwell (1831-1879), que a luz encontrou uma relação com os efeitos elétricos e magnéticos. Como Pedrosa (2009, p.28) nos lembra, o nosso mundo material é composto de substância e de luz. E as substâncias que compõem desse mundo são constituídas unicamente por elétrons, prótons e nêutrons. De acordo com o mesmo autor, todos os corpos quentes, com temperatura superior a zero absoluto $\left(-273^{\circ} \mathrm{C}\right)$, emitem luz, existindo neles um movimento de partículas. Quando esses corpos estão expostos no período noturno não há fonte de luz para aquecê-los, não emitirão senão raios infravermelhos, inferiores à 
faixa de radiação necessária para a visão humana. Apenas quando esses corpos são fortemente aquecidos é que passam a conter, em sua luz, raios visíveis aos nossos olhos.

Ainda de acordo com Pedrosa (2009, p.28), ao se descobrir que a luz é um fenômeno eletromagnético, abriu-se o caminho para o entendimento de novos ângulos das relações existentes entre a luz e a substância material. Surgiu a possibilidade de explicação de como a luz imprime coloração nos corpos. Toda substância está constituída de partículas portadoras de carga elétrica, de núcleos positivos e elétrons negativos que geram ondas eletromagnéticas invisíveis. Quando ondas eletromagnéticas de luz visível, oriundas de outras fontes energéticas, caem sobre os átomos e moléculas, fazendo vibrar as partículas carregadas de eletricidade, a energia das ondas incidentes vê-se dispersa, absorvida e refletida simultaneamente em graus diferentes, de acordo com a composição molecular da superfície atingida. O fenômeno da coloração percebida sobre os corpos (substância) é o resultado dessa reação das partículas eletricamente carregadas em relação à ação da onda eletromagnética (luz) incidente. As substâncias (os objetos ou os corpos) não têm cor. O que têm é uma capacidade de absorver, refratar ou refletir determinados raios luminosos que sobre elas incidam.

\section{Padronização da informação luminosa}

Segundo Bouma (1947, p.15), foi nos séculos XVIII e XIX que, com os avanços da física, a luz passou a ser considerada um fenômeno de auto-propagação de vibrações, e as várias cores espectrais se distinguiram entre si através de sua freqüência. A fim de se padronizar a linguagem da cor internacionalmente, Pedrosa (2008, p.110) nos descreve a padronização mundial para a colorimetria, denominada padronização tricromática, criada para superar a insuficiência vocabular de todos os idiomas na designação das cores, o que facilitou o intercâmbio internacional de corantes químicos e instrumentos eletrônicos de criação e manipulação de cores. Ainda segundo Pedrosa (2008, p.110), a partir de seu desenvolvimento, o Diagrama Cromático, indicado pela Comissão Internacional de Iluminação (CIE), passou a ser a imagem visível do vocabulário matemático das cores, expresso em milimícrons. 


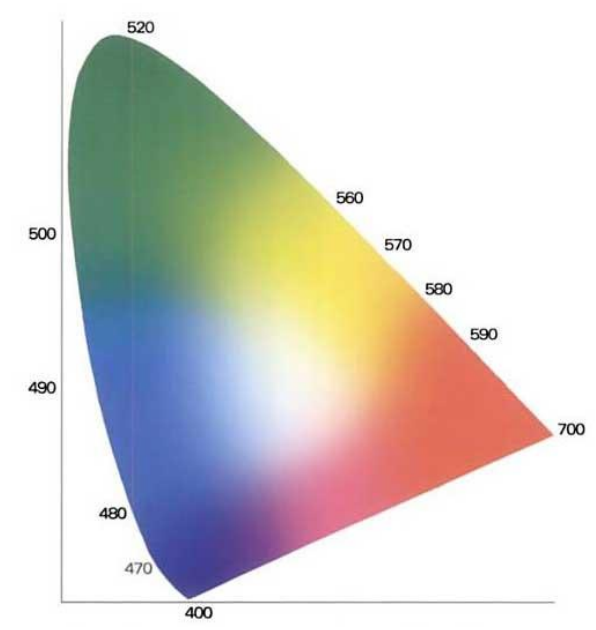

Figura 32: O diagrama tricromático da composição da luz branca, síntese da parte visível do espectro solar, compreendida entre $400 \mathrm{~m} \mu$ e $700 \mathrm{~m} \mu$. Fonte: (PEDROSA, 2008, p. 110)

Sendo o raio solar (a melhor expressão da luz branca) uma síntese do espectro eletromagnético, nele estão contidas todas as cores. Como o espectro é contínuo, as cores se interpenetram na passagem de uma para a outra, criando misturas que definem sua composição. Essa interpenetração, por ser constitucional das cores, elimina qualquer possibilidade da existência de uma cor pura. A cor pura passa então para o reino encantado da abstração vocabular, aumentando ainda mais seu fascínio (PEDROSA, 2008, p. 111).

A unidade de medida que utilizaremos para fazer referência à luz e para delimitar o comprimento de onda, será o milimícron $(\mathrm{m} \mu)$. A tabela a seguir apresenta o valor de comprimento de onda de cada cor do espectro. Esse valor engloba uma faixa de comprimento para cada cor, mas é bastante relativo pois cada um pode determinar a percepção cromática de uma cor de forma distinta. O espectro visível que se constitui pelas ondas de luz que o olho humano consegue perceber vai de $400 \mathrm{m \mu}$, que representa o violeta, até os $700 \mathrm{~m} \mu$, que representa o vermelho. Os comprimentos de onda abaixo de $400 \mathrm{~m} \mu$ correspondem às cores ultra-violetas e acima de $700 \mathrm{~m} \mu$, às infravermelhas.

RADIAÇÃO SOLAR

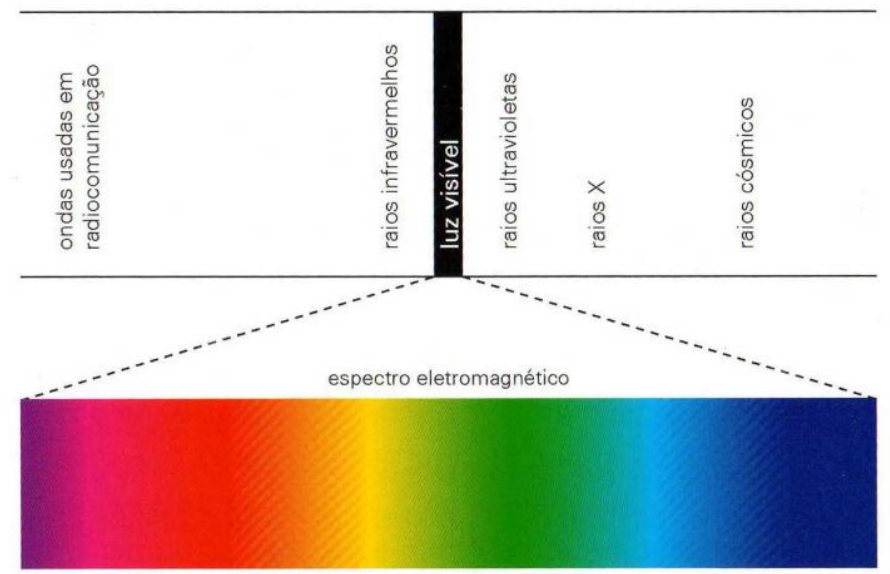

Figura 33: Faixa de radiações visíveis compreendida entre os raios infravermelhos e os ultravioletas.

Fonte: (PEDROSA, 2008, p.20) 


\begin{tabular}{|c|c|c|c|}
\hline \multicolumn{4}{|c|}{$\begin{array}{l}\text { RESUMO DA TABELA DOS ESTÍMULOS } \\
\text { TRICROMÁTICOS DO ESPECTRO } \\
\text { Adotada pela Comissão Internacional de lluminaçáo (CIE) - } 1931\end{array}$} \\
\hline $\begin{array}{l}\text { COMPRIMENTO DE } \\
\text { ONDA }(m \mu)\end{array}$ & $\begin{array}{c}\mathrm{X} \\
\text { (vermelho) }\end{array}$ & $\begin{array}{c}Y \\
\text { (verde) }\end{array}$ & $\underset{\text { (azul) }}{z}$ \\
\hline 400 & 014.310 & 000.396 & 067.850 \\
\hline 410 & 043.510 & 001.210 & 207.400 \\
\hline 420 & 134.380 & 004.000 & 645.600 \\
\hline 430 & 283.900 & 011.600 & 1.385 .600 \\
\hline 440 & 348.280 & 023.000 & 1.747 .060 \\
\hline 460 & 290.800 & 060.000 & 1.669 .200 \\
\hline 480 & 095.640 & 139.020 & 812.950 \\
\hline 490 & 032.010 & 208.020 & 465.180 \\
\hline 500 & 004.900 & 323.000 & 272.000 \\
\hline 510 & 009.300 & 503.000 & 158.200 \\
\hline 520 & 063.270 & 710.000 & 078.249 \\
\hline 540 & 290.400 & 954.000 & 020.300 \\
\hline 560 & 594.500 & 995.000 & 003.900 \\
\hline 580 & 916.300 & 870.000 & 001.650 \\
\hline 600 & 1.062 .200 & 631.000 & 000.800 \\
\hline 620 & 854.449 & 381.000 & 000.190 \\
\hline 640 & 447.900 & 175.000 & 000.020 \\
\hline 660 & 164.900 & 061.000 & \\
\hline 680 & 046.770 & 017.000 & ......... \\
\hline 690 & 022.700 & 008.210 & .......... \\
\hline 700 & 011.359 & 004.102 & .......... \\
\hline
\end{tabular}

Figura 34: Resumo da tabela dos estímulos tricromáticos, $\mathrm{X}, \mathrm{Y}$ e Z.

Fonte: (PEDROSA, 2008, p.112)

De acordo com a tabela de Estímulos Tricromáticos e com a descrição de Pedrosa (2008, p.112), a composição do violeta, de $400 \mathrm{~m} \mu$ de comprimento de onda, segue uma proporção de 014.310 unidades de vermelho, 000.396 de verde e 067.850 de azul. O vermelho, cujo comprimento de onda é de $700 \mathrm{m \mu}$, é composto de 011.359 unidades de vermelho e 004.102 unidades de verde. O amarelo, de $560 \mathrm{m \mu}$, é composto por 594.500 unidades de vermelho, 995.000 de verde e 003.900 unidades de azul.

Farina (2006, p.29) ressalta que qualquer coisa que provoque uma reação em algum órgão do sentido é um estímulo, e que todos os estímulos visuais têm características próprias: tamanho, proximidade, iluminação e cor. Para os artistas que trabalham com a luz, é de fundamental importância que conheçam essas propriedades quando pretendem comunicar-se.

Ainda segundo Farina (2006, p.30), o que o homem percebe ao seu redor é o resultado da relação entre as propriedades do objeto e a natureza do indivíduo que observa. $\mathrm{O}$ homem decifra as informações e as processa de acordo com sua percepção. Para o artista, muitas vezes, é impossível prever a reação dos receptores de uma obra interativa, mas o processo pelo qual o artista desenvolve sua poética inclui a ligação com o receptor por meio de estímulos e, no caso do presente estudo, o estímulo que privilegiamos é a cor como fonte luminosa. 
A cor, como fonte luminosa, levando em conta Plaza (1986, p.133), manifesta-se sem significado, por ser ela pura "forma-luz". Ela é um signo em estado de abertura para interpretações, passíveis de uma multiplicidade de significados. No entanto, complementa o autor, a cor pode passar a ser suporte de significação quando aliada a formas analógicas, o que resulta numa organização de linguagem mais complexa.

Baseado em estudos lançados recentemente, Farina (2006, p. 30) conclui que a percepção é um processo que se fundamenta na ação, na probabilidade e na experiência. A imagem que percebemos é um elemento do processo de perceber. $\mathrm{O}$ ato de percepção depende de um conjunto de processos físicos que promovem a sensação da cor, específico com matizes distintas para cada indivíduo.

\subsection{Aspectos psicológicos da cor}

Apesar de sabermos que a cor sempre influenciou as pessoas ao longo dos séculos, os estudos na área da psicologia sobre a cor só vieram a avançar no início do séc. XX, com as pesquisas e experimentações de Goethe acerca da cor e seus efeitos no observador. Antes desse momento, a cor era vista como um efeito óptico estritamente calculado.

Segundo Danger (1973, p.25), foi Goethe quem analisou a reação das pessoas quanto ao grupo de cores quentes e frias, denominação já mencionada ao se falar sobre os sistemas cromáticos. A partir de Goethe, foi possível concluir como a cor afeta a mente humana: as pessoas, quase sempre, se sentem mais alegres num dia pleno de sol do que num dia nublado. Ainda segundo Danger (1973), quando a abundância de luz é acompanhada de cores luminosas, e quentes, o corpo sente-se mais ativo e tal ambiente tende a encorajar ação e os esforços musculares. Já, em dias e lugares menos luminosos, com tons mais frios: cinza, azul, verde, turquesa, o autor explica que há menos distração e a pessoa sente-se mais capaz de concentrar-se em tarefas sedentárias e mentais.

Para completar as informações a respeito da Doutrina das Cores, Fraser e Banks (2007, p.48) afirmam que Goethe, ao abordar a cor por meio de observações da percepção humana, em lugar da física da luz, abrangeu uma área bem maior que a de Newton: explorou simultaneamente o contraste, a imagem residual, a cor das sombras e o efeito da iluminação sobre os objetos, e considerou como as cores podem se relacionar a estados emocionais. Ele também formulou as proporções das forças de diferentes 
matizes para combiná-los em proporção visual igual. Até os dias atuais artistas se baseiam em seus princípios.

A cor, conforme nos conta Farina (2006, p.85), é uma realidade sensorial à qual não podemos fugir. Além de atuar sobre a emotividade humana, as cores produzem uma sensação de movimento, uma dinâmica envolvente e compulsiva. $\mathrm{O}$ autor compara a cor amarela a uma força expansiva que transborda seus limites espaciais; o vermelho é considerado agressivo embora equilibrado sobre si mesmo; já o azul transmite uma sensação de vazio, distância e profundidade.

Para Farina (2006, p.85), determinadas cores podem produzir a sensação de proximidade e, outras, de distância. Podemos notar esse efeito em obras artísticas que parecem promover o contato com o receptor ou, às vezes, causar um estranhamento. Mas o autor lembra que mesmo sabendo que as cores(matizes) podem ter o poder de aproximar ou afastar, isso dependerá, muitas vezes, de outros fatores agregados como a iluminação(valor) e a saturação(croma).

Em se tratando de arte, o que nos interessa na investigação dos aspectos psicológicos da cor é compreender como se dá a relação entre cor e homem, como a cor afeta o humor e as escolhas das pessoas. Com base nesses dados, os artistas podem estruturar suas obras, caso busquem envolvimento com a cor e abertura ao receptor. $\mathrm{O}$ bom entendimento destes conceitos poderá facilitar e ampliar as possibilidades de uso da cor, oferecendo ao artista o poder de controlar as leis que as regem.

\subsubsection{Estímulos provenientes da cor}

Segundo BARROS (2007, p.283), foi Goethe (1749-1832) quem ofereceu pela primeira vez uma abordagem simbólica da cor, ao descrever estados de ânimo e sensações específicas associadas a cada uma das cores do círculo - visualizados a seguir.

(...) cada cor produz um efeito específico sobre o homem ao revelar sua essência tanto para o olho quanto para o espírito. Conclui-se daí que as cores podem ser utilizadas para certos fins sensíveis, morais e estéticos (GOETHE, p.154 apud BARROS, 2007, p.302). 

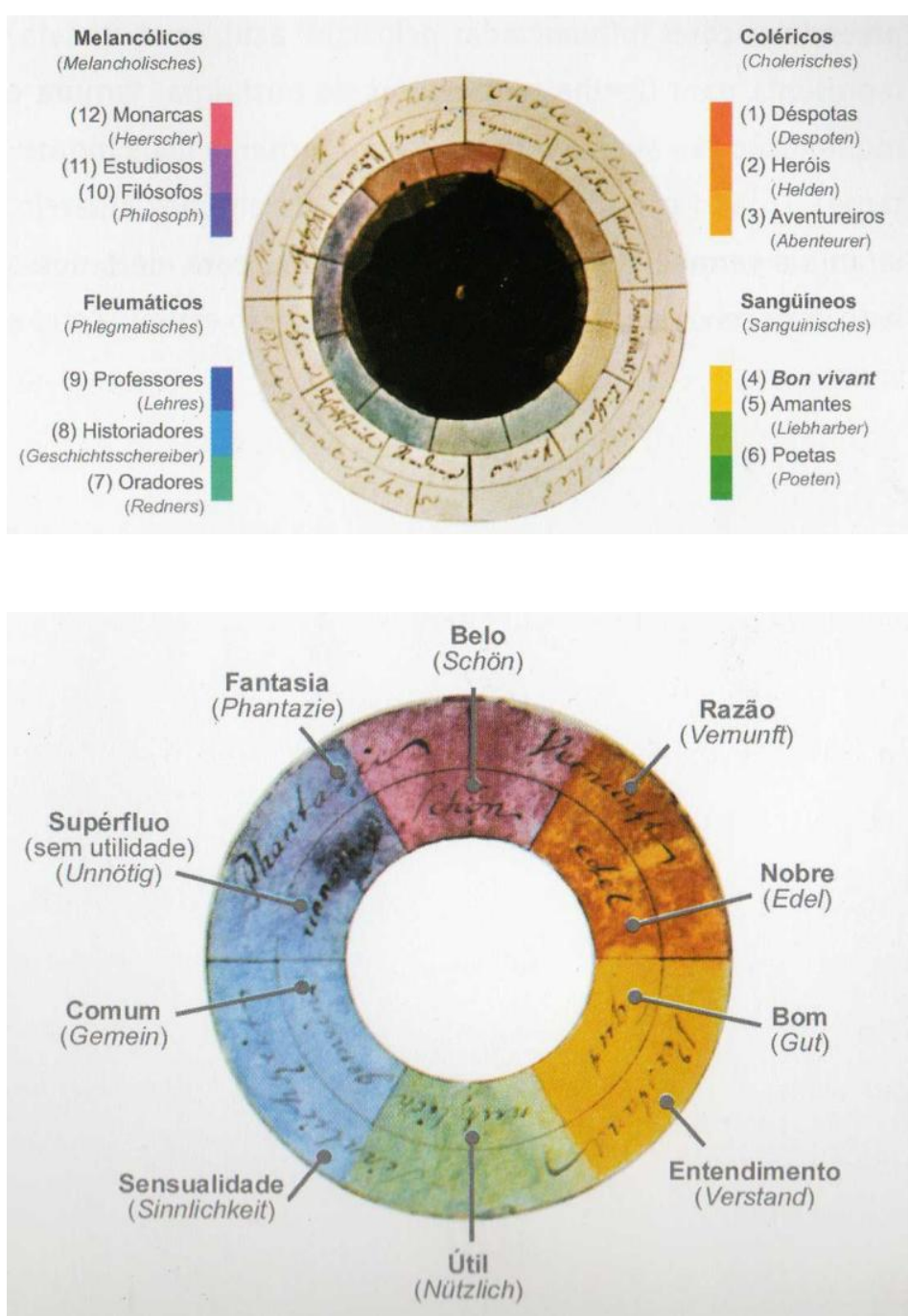

Figura 35: Rosa dos temperamentos.

Uma visão simultânea de Goethe e Schiller sobre a associação das cores com os temperamentos humanos (1799).

Fonte: (BARROS, 2007, p.303)
Figura 36: Diagrama dos poderes da alma. Goethe (1807). Fonte: (BARROS, 2007, p.303)

A partir desses conceitos deixados por Goethe, muitos foram os pesquisadores que deram continuidade e ampliaram a compreensão dos efeitos das cores. Em seu livro $D a$ cor à cor inexistente, Israel Pedrosa abordou, com muita competência, as características, propriedades e efeitos das cores. Torna-se imprescindível citar trechos das descrições feitas por ele.

Vermelho: [...] É a cor que mais se destaca visualmente e a mais rapidamente distinguida pelos olhos. [...]. Cor do fogo e do sangue, o vermelho é a mais importante das cores para muitos povos, por ser a mais intimamente ligada ao princípio da vida. [...] Em todos os países do mundo, o vermelho significa perigo e sinal fechado para o trânsito. Por sua capacidade de penetrar mais profundamente a neblina e a escuridão do que as outras cores, ele é usado como luz de alarme, nas torres elevadas, cimo dos edifícios, proas de embarcações, etc (PEDROSA, 2009, p.118-121). 
A cor vermelha é uma das cores primárias e cor complementar do ciano em fonte luminosa. É ela que inicia as cores do espectro estando em lado oposto ao violeta. Por ser uma cor forte e altamente saturada infunde sensações fortes.

De acordo com Farina (2006, p.87), os significados conotativos que estão ligados à cor vermelha são: calor, dinamismo, ação e excitação. É uma cor quente e bastante excitante para o olhar que impulsiona a atenção e a adesão aos elementos em destaque. Por possuir ondas longas, o tempo de percepção do vermelho é de 0,02 segundos. Segundo Farina, em muitos idiomas, o vermelho significa também colorido e em, outras línguas, é o caso do russo, existe uma sinonímia entre bonito e vermelho.

O vermelho se associa fortemente ao sangue, é a cor do coração e da carne. De acordo com Tornquist (2008, p.261), vermelho significa simplesmente paixão pois "está sempre associado, para o bem ou para o mal, a fortes emoções, a coragem na luta, sexo e perigo, prazer de viver e cólera, desejo e assassinato, sangue derramado no sossegado verde da natureza." O vermelho, ainda segundo o autor, é responsável pela aceleração do ritmo cardíaco e transmite a sensação de calor em quem o observa. O vermelho é também a primeira cor que nossos olhos percebem depois de um longo período na escuridão, por isso é o mais utilizado para sinalizar uma informação à distância. Para Tornquist, o coração vermelho é símbolo do amor.

Amarelo: [...] $\mathrm{Na}$ distinção psicológica de cores quentes e frias, o amarelo é o termo de definição, por ser a cor quente por excelência. [...] Em muitos países simboliza o despeito e a traição. É também o símbolo do desespero, por ser intenso, violento e agudo até a estridência. Amplo e ofuscante como uma corrida de metal incandescente, é a mais desconcertante das cores, transbordando dos limites onde se deseja encerrá-lo, parecendo sempre maior do que é na realidade, devido à sua característica expansiva (PEDROSA, 2009, p. 122-123).

A cor amarela é, no âmbito da mistura aditiva de luz, secundária na mistura das cores luminosas primárias: verrmelho e verde; e complementar ao azul. A cor amarela é a cor mais clara do espectro, situada entre as cores laranja e verde. Seu brilho intenso caracteriza-a como cor quente, mas não tanto quanto a cor vermelha. Ao se deparar com a luz amarela, os cones verdes e vermelhos de nossos olhos são excitados em igual 
medida, característica que em função da qual Tornquist (2008, p.265), considera o amarelo uma cor muito visível.

Conforme Farina (2006, p.101), o amarelo remete à alegria, espontaneidade, ação, poder, dinamismo e impulsividade. Pode ainda sugerir potencialização, estimulação, contraste, irritação e covardia. Em síntese, o amarelo é uma cor altamente luminosa: chama muita atenção e desperta os impulsos de adesão do receptor.

No ocidente a associação do amarelo inclina-se a ser menos positiva do que a mesma vista pelos orientais. Isso se deve, como nos relata Tornquist (2008, p.264), ao fato de que desde a época em que Judas foi representado com vestimentas amarelas, não cessou na história ser o amarelo relacionado à corrupção, à inveja e à falta de sinceridade, hostilidade.

$\mathrm{Na}$ reino animal, o amarelo é cor de advertência por estar associada, conforme Tornquist (2008, p.265), a insetos que picam, peixes venenosos e répteis.

Cabe aqui destacar o uso das cores amarelas quando associadas, em igual valor, ao verde. De acordo com Tornquist (2008, p.265), essa combinação de cores sinalizava desordem e loucura, em função de o verde/amarelo ser próprio das roupas dos loucos e da fantasia dos bobos da corte. Essa associação se reforça ainda, por ser o amarelo esverdeado a cor das casas de loucos no manicômio.

Verde: [...] É o ponto ideal de equilíbrio da mistura do amarelo com o azul. As potencialidades diametralmente opostas das duas cores claridade e obscuridade, calor e frio, aproximação e afastamento, movimento excêntrico e movimento concêntrico - anulam-se e surge um repouso feito de tensões. [...] Internacionalmente, identificou-se com o grito de exclamação: Viva!, descarga emocional do homem motorizado diante do sinal verde representativo de passagem permitida, trânsito livre (PEDROSA, 2009, p.123-125).

A cor verde é, em mistura aditiva, luminosa, cor primária. É complementar à cor magenta. Quando misturada ao azul, produz o ciano e, ao vermelho, o amarelo. 
É a posição equilibrada decorrente da mistura do amarelo ativo com o azul que relaxa. Segundo Farina (2006, p.101), o azul transmite ao verde uma característica sedativa: sugere calma e frescor. Remete também aos sentimentos de esperança, amizade e equilíbrio. Por isso mantém forte ligação com causas ambientais.

O lado negativo do verde pode ser comparado à sua aproximação à ira. De acordo com Tornquist (2008, p.263), o verde se associa primeiramente à raiva, o que ele enfatiza ao comparar os seguintes ditos populares: "verde de raiva", "ficar verde", "ficar verde de inveja". O verde, tal como mencionamos, vincula-se fortemente ao que é de origem natural, podendo representar tanto o verde das florestas e da umidade quanto o verde da decomposição e putrefação.

Azul: [...] Todas as cores que se misturam com o azul esfriam-se, por ser ele a mais fria das cores. [...] O azul é a mais profunda das cores o olhar o penetra sem encontrar obstáculo e se perde no infinito. É a própria cor do infinito e dos mistérios da alma. Devido a afinidades intrínsecas, a passagem dos azuis intensos ao preto faz-se de forma quase imperceptível. O azul é, ainda, a mais imaterial das cores, surgindo sempre nas superfícies transparentes dos corpos. [...] (PEDROSA, 2009, p.125-127).

O azul é cor fria e a cor mais escura das primárias luminosas; é indecomponível. Possui como par complementar a cor amarela. Na mistura aditiva, o azul pode produzir o magenta, ao ser somado à luz vermelha e pode produzir também o ciano ao ser somado à luz verde.

De acordo com pesquisas de Pastoureau e Heller, citadas por Farina (2006, p.102), a cor azul é a preferida por mais da metade da população ocidental: é a cor mais lembrada ao se referirem à simpatia, à harmonia, à amizade e à confiança. Por ser a cor do céu, atribui-se ao azul um significado de ordem divina: é a cor da eternidade e de tudo o que se deseja que permaneça. Segundo o mesmo autor a cor azul tem ondas curtas e por isso seu tempo de percepção é de 0,06 segundos. Por ser a cor do infinito, associa-se ainda à cor do sonho, de algo longínquo e do que se espera realizar. O azul, segundo Tornquist (2008, p.266), possui um caráter tranquilizante: abaixa a pressão sanguínea, a frequência cardíaca e remete à liberdade. 
O matiz azul-escuro, nas considerações de Farina (2006, p.102), indica sobriedade, sofisticação, inspiração, profundidade e se harmoniza com a idéia de liberdade e acolhimento. O azul-escuro está imbuído de profundidade por vincular-se às profundezas do mar.

\begin{abstract}
Violeta: [...] É o violeta a cor da temperança. Reúne as qualidades das cores que the dão origem (vermelho e azul), simbolizando a lucidez, a ação refletida, o equilíbrio entre a terra e o céu, os sentidos e o espírito, a paixão e a inteligência, o amor e a sabedoria. [...] Em tons escuros, o violeta está ligado à idéia de saudade, ciúme, angústia e melancolia, tornando-se deprimente. Em tons claros, é alegre e aproxima-se das variedades do rosa (PEDROSA, 2009, p.127-128).
\end{abstract}

Todas as cores que resultam da mistura entre vermelho e azul recebem a denominação de violeta. Como cor luminosa, a mistura entre azul e vermelho é denominada magenta, tonalidade que se aproxima do violeta purpurino conforme nos expõe Pedrosa (2009, p.127). O violeta é a cor que ocupa o final do espectro de cores visíveis, portanto, com a menor frequência de radiação.

Sua significação, conforme Farina (2006, p.103) transmite sensações por vezes antagônicas: engano, miséria, calma, dignidade, autocontrole, violência, furto e agressão.

Por ser o violeta a cor com menor frequência de radiação, ela é considerada a mais silenciosa do espectro. De acordo com Tornquist (2008, p.266), o violeta é a cor da meditação. O violeta, conclui o autor, muda facilmente seu caráter ao mover-se entre o vermelho e o azul.

Laranja: [...] Cor quente por excelência, sintetiza as propriedades das cores que lhe dão origem. Em comparação com cores mais frias, parece avançar em direção ao observador. Tem grande poder de dispersão. As áreas coloridas pelo laranja parecem sempre maiores do que são na realidade. [...] $\mathrm{O}$ difícil equilíbrio do laranja, entre o vermelho e o amarelo, vinculava-se ao não menos difícil equilíbrio entre o espírito e a libido, passando o laranja a simbolizar, também, a infidelidade e a luxúria (PEDROSA, 2009, p.128-129). 
A cor luminosa laranja é terciária, produzida pela soma de vermelho e verde em quantidades desiguais. É um matiz caracterizado quente.

Conforme Farina (2006, p.100), a cor laranja significa transformação. É uma cor que se associa à ofensa, perigo, robustez, desejo, dominação, força, euforia, energia, advertência, prazer e senso de humor.

A cor laranja, de acordo com Tornquist (2008, p.267), estimula a velocidade, a dissipação de energia e a extroversão. Do ponto de vista psicológico, o autor descreve o laranja como mais próximo do amarelo do que do vermelho, mas sem a determinação de nenhum dos dois. A cor laranja também é muito visível, e na opinião do autor, pode ser utilizada como sinal luminoso para chamar a atenção sobre elementos em movimento.

Branco: [...] O branco é a cor da pureza, campo que não originou ainda uma cor definida, que é como uma promessa, a expectativa de um fato a se desenvolver. [...] Como reflexo de uma aspiração dominante, o branco encontra seu maior significado no século XX, representando a paz, principalmente a paz entre os povos. É neste sentido que ele aparece na bandeira da Organização das Nações Unidas (ONU), desenhando sobre fundo azul o globo terrestre e os ramos de louro que o cercam (PEDROSA, 2009, p.130-131).

O branco é o resultado da soma de todas as cores luminosas, também é obtido ao somarse uma cor luminosa qualquer a que lhe é complementar. O branco ilumina qualquer matiz apregoando valor e intensidade.

Para Farina (2006, p.97), o branco expressa neutralidade, pureza, vida, limpeza, castidade, liberdade, criatividade, mas por outro lado, é uma cor irritante devido ao seu alto grau de luminosidade (por nela estarem contidas todas as cores do espectro). $\mathrm{O}$ branco também pode remeter a algo incorpóreo, associando-se à espiritualidade. É também a cor do vazio interior, da carência afetiva e da solidão. Ainda para o autor, o branco simboliza a luz e não deve ser considerado cor, pois de fato não é. Para os ocidentais, o branco simboliza o bem. 
Preto: [...] Psicologicamente, encarna a profundeza da angústia infinita, em que o luto aparece como símbolo de perda irreparável. [...] Evocando o caos, o nada, o céu noturno, as trevas terrestres, o mal, a angústia, a tristeza, o inconsciente e a morte, o preto é o símbolo maior da frustração e da impossibilidade (PEDROSA, 2009, p.131-133).

A cor preta resulta da ausência de luz. De acordo com Pedrosa (2009, p.131), em condições normais, o preto absoluto não existe na natureza. Os corpos pretos só são plenamente visualizados através dos bastonetes. Por isso, o preto alcança seu maior índice de contraste quando próximo ao branco. Representa a falta total de iluminação.

Para Farina (2006, p.98), o preto corresponde à busca das sombras e da escuridão, é a cor da vida interior sombria e depressiva. O preto remete à morte, destruição e tremor, mas em determinadas situações pode se associar à sofisticação e requinte. Pode, no entanto, se tornar alegre quando associado a certas cores.

A reação dos indivíduos a cada uma das cores é uma sensação particular, mas o que se tentou aqui foi reunir os significados atribuídos comumente às cores na cultura ocidental. Neste caso, optou-se por classificar a cor com base no que é praticado na cultura ocidental que é o foco desta pesquisa. Os aspectos psicológicos estão intimamente ligados aos aspectos culturais da cor, um dependente do outro no que se refere ao indivíduo. A seguir, investigaremos o comportamento das culturas em relação à cor a fim de complementar e concluir o objetivo deste capítulo: estudar a cor em seus fundamentos teóricos e nos estudos realizados sobre o tema.

\subsection{Aspectos culturais da cor}

Nesta pesquisa assumiremos que os indivíduos possuam uma acuidade relativamente normal não impedindo deste diferenciar as cores. Sabemos que existem pessoas que possuem alguma anomalia visual e, nesse caso, não entraremos em detalhes por não ser este, o objeto desta pesquisa. Tomando-se como fato que a população "vê" de maneira igual do ponto de vista fisiológico, uma das razões das sensações diferentes a partir da mesma cor é a realidade cultural em que se insere o receptor. 
Dado o contexto contemporâneo que esta pesquisa se insere, tratado a partir do estudo da cor como fonte luminosa em instalações das Novas Tecnologias da Comunicação na cultura ocidental, nota-se que, por sua recente e atual aplicação, ela (a cor de fonte luminosa) faz parte de uma cultura dinâmica que varia ao ritmo da evolução, desenvolvimento e aprimoramento de códigos visuais e de linguagem. Neste sentido, Guimarães (2000, p. 100) assinala o fato de que a cultura é dinâmica e se transforma na relação tempo e espaço em que se insere. O que temos hoje de informação cultural, pode se dizer que é uma soma de códigos informacionais que se estabeleceram, ganharam espaço e se sobrepuseram ao longo do tempo. Nossa visão é diferente de nossos antecessores em outro contexto histórico-cultural. No artigo de Eco de 1985, intitulado How Culture Conditions the Colours we See, ele cita a passagem:

"We know much about Roman sculpture and architecture, but very little about Roman painting. The colours we see today in Pompeii are not the colours the Pompeians saw; even if the pigments are the same, the chromatic responses are not." ${ }^{3}$ (ECO, 2008, p.178)

O entendimento da questão temporal não é suficiente para reconstituir o significado da cor para uma determinada cultura. Guimarães (2000, p.98) menciona o espaço como um segundo valor determinante e transformador da percepção das cores. Por exemplo, cada sociedade num espaço geográfico específico se relaciona de modo diferente com as cores. Guimarães cita o exemplo do povo brasileiro que tem mais facilidade para perceber as nuanças entre o amarelo e o vermelho, pois temos um repertório rico dessas cores em nossas riquezas naturais. Cita ainda o exemplo da população inglesa cuja cultura é muito mais fecunda nos tons neutros, o que facilita a identificação das nuanças entre o azul e o violeta. Segundo Gage existem outros níveis de informação que necessariamente precisam ser esclarecidos para uma total compreensão dos aspectos culturais da percepção da cor:

\footnotetext{
3 "Nós sabemos muito sobre escultura e arquitetura romanas, mas muito pouco sobre pintura romana. As cores que vemos hoje em Pompéia não são as cores que os pompeus viram; mesmo se os pigmentos fossem os mesmos, as respostas cromáticas não seriam.” Os textos originais em língua inglesa, a partir de agora, serão traduzidos pela autora deste trabalho e assim identificados: (T.A.).
} 
"I have hardly mentioned perhaps the most important issue of all: the definition of culture itself. Which sector of a given society is in question? Which age-group, with class, with profession, with gender?"4 GAGE (1999, p.33)

A análise da cor em seu contexto cultural não causa tanto interesse entre os cientistas devido à complexidade do tema. Concentram-se mais, de acordo com Gage (1999, p.21), nos estudos físicos e fisiológicos da cor, por exemplo, o estímulo radiante de luz e o processamento fisiológico deste estímulo para os olhos.

Esclarece-nos Gage (1999, p.21) que a cor está ligada intimamente à linguagem verbal. A língua é um sistema de signos arbitrários com a função de ferramenta para a comunicação. As palavras têm sua história e uma dimensão cultural que configura a significação da cor. A cor é, na atualidade, delimitada em várias línguas por terminologias com um número limitado de matizes. Quando a matiz a ser definida não dispõe de terminologia própria, opta-se por identificar a cor com fenômenos ou figuras da natureza. A origem disto remonta aos arquétipos de experiência humana a esse respeito Gage (1999, p.22) cita as associações, ao nomear noite preta, osso branco, sangue vermelho e assim por diante. O mesmo autor complementa que o lado negativo dessa associação é que a cor passa para segundo plano, perdendo sua importância.

As razões culturais que levaram à limitação de termos que signifiquem as cores surge, de acordo com Gage (1999, p.24), devido à tendência de sistematizar e reduzir o número de informações. Para ilustrar essa afirmação, Gage faz menção a Newton que, ao sistematizar em gráfico, a divisão das cores contidas no espectro, elegeu apenas 7 cores principais como representantes de um espectro formado por milhares de matizes. Olhos bem treinados de artistas que lidam diariamente com a cor, conseguem discernir mais cores do que um individuo sem tamanha sensibilidade visual. Essa restrição na terminologia para identificar cores variantes das sete cores principais leva o ser humano a utilizar as associações com outros objetos ou elementos naturais: azul do céu, amarelo ouro e assim por diante.

\footnotetext{
${ }^{4}$ Eu quase nunca falei talvez sobre o assunto mais importante de todos: a definição da própria cultura. Qual setor de uma dada sociedade está em questão? Qual faixa etária, qual classe social, qual profissão, qual gênero?" (T.A.)
} 
"What the history of the spectrum suggests is that there are real difficulties in perceiving and identifying colours in complex arrays, especially when their edges are undefined, and that the relative poverty of colour-vocabularies reflects these difficulties, and encourages representations to be far more concerned with ideas about colours than with colour-perceptions themselves."5 GAGE (1999, p.26)

Para Pedrosa (2009, p.110), a variedade de significação de cada cor, ao longo dos tempos, está intimamente ligada ao nível de desenvolvimento social e cultural das sociedades que o criam.

"Os diversos elementos da simbologia da cor, como em todos os códigos (visuais, gestuais, sonoros ou verbais), resultam da adoção consciente de determinados valores representativos, designativos ou diferenciadores, emprestados aos sinais e símbolos que compõem tais sistemas ou códigos. Com efeito, o que dá qualidade e significado ao símbolo (sinais sonoros, verbais ou visuais) é sempre sua utilização. Por isso a criação dos símbolos mais significantes e duráveis é, via de regra, ato coletivo de função social, para satisfazer certas necessidades de representação e comunicação.” PEDROSA (2009, p.110)

A partir dessas observações é possível mencionar que os códigos utilizados para referenciar a cor foram, ao longo do tempo, à medida em que as sociedades evoluiam, ganhando uma maior complexidade, justificando assim o fato de que os aspectos culturais se compõem ao longo do tempo e variam, nunca permanecendo os mesmos. $\mathrm{O}$ uso que um determinado indivíduo faz da cor passa então a sofrer influência direta do meio ao qual está inserido, influenciando sua percepção para identificar uma cor.

"Da utilização da cor no ritual ao puro gosto pela cor vai um longo caminho de evolução social e psíquica em que participam inúmeros elementos conturbadores. Dai ser tão complexa a definição do gosto estético em geral. Não bastam esquemas apriorísticos de herança cultural, de estágios sociais, de características individuais, etc., tomados isoladamente, para determinar-lhe as causas. A mutabilidade do gosto com variantes coletivas e individuais em períodos mais ou menos curtos e seus estágios hierárquicos de preferência constituem o núcleo de dificuldade de conceitua-lo.” PEDROSA (2009, p.111)

\footnotetext{
5 “O que a história do espectro sugere é que existem reais dificuldades em se perceber e identificar as cores em complexas disposições, especialmente quando suas extremidades são indefinidas, e que a relativa pobreza de vocabulário para cor reflete essas dificuldades, e incentiva representações a serem bem mais relacionadas com as idéias sobre cores do que com a percepção delas mesmas.”
} 
A respeito da preferência de cores, Pedrosa (2009, p.111) nos faz pensar que a formação destas predileções levam em consideração sempre o efeito da ação física da cor sobre o organismo humano, condicionado pelas reminiscências do uso individual e social da cor. Segundo ele, a preferência dos povos das regiões tropicais por roupas brancas se deve ao excessivo calor, efeito da grande quantidade de raios luminosos que, ao incidirem nas vestimentas brancas, são refletidos, aliviando a sensação do calor. Por outro lado, as outras cores absorvem e refletem parte dos raios luminosos baseadas na lei de absorção e reflexão dos raios luminosos.

Entende-se que os aspectos culturais da cor são construídos de acordo com cada sociedade, se moldando a sua realidade, seja ela temporal ou espacial. Caberá a cada indivíduo dessa sociedade desenvolver sua percepção visual a fim de poder participar do processo comunicativo neste espaço em que está inserido.

O entendimento e uso gradual da cor pelo sentido se deu com a finalidade de atingir o receptor e torná-lo um agente participante e ativo da obra. Ao longo da história, os artistas utilizaram o conhecimento que adquiriram com os cientistas sobre descobertas compositivas e de harmonia da cor e transportaram para a obra através da pintura.

O repertório construído no âmbito das teorias cromáticas respaldou artistas que passaram a fazer da cor um uso cada vez mais intencional e calculado. Esse conhecimento foi aos poucos influenciando o surgimento de movimentos artísticos que, abertos a esse tipo de informação, estreitaram os laços entre o campo científico e artístico.

A cor passou a ser utilizada pelos artistas cada vez mais no intuito de capturar a atenção do observador que, como veremos no capítulo seguinte, assumirá um papel ativo na obra. E a cor materializada pela luz assumiria nas mãos dos artistas um papel de significação com grande domínio sobre o participante. Sua articulação como instrumento e dispositivo artístico só se fez possível pela relação cada vez mais próxima entre a ciência e a arte, resultando em descobertas tecnológicas que amplificaram a expressividade poética dos artistas ao longo dos tempos. 
"Colour will always be interpreted in a new way... infinite change may be its constant nature"

Donald Judd 


\section{Capítulo 3}

\section{A busca da inserção do receptor pela cor como fonte luminosa na arte}

A luz desde os primórdios da humanidade, quando o homem descobria o fogo sempre desencadeou fascínio. Esse deslumbramento permanece até os dias de hoje. O homem continuamente trabalha no sentido de dominar a luz e dela se apropriar. Aliado ao desenvolvimento da ciência e da tecnologia, o homem de hoje tem condições de gerar e projetar a luz artificialmente em lugar de restringir-se aos meios naturais. Ao apropriar da luz, o homem controla as emissões cromáticas a ela vinculadas, a partir de filtros ou de dispositivos tecnológicos específicos.

A luz e o iluminar nunca estão relacionados a qualquer expressão negativa, e é acima de tudo a "descoberta de novos espaços de entendimento" de acordo com Ferreira (2006, p.4). A luz detém um significado simbólico, a autora considera a luz "como uma metáfora do conhecimento e da cultura" e enfatiza ser a luz símbolo da salvação e da felicidade e seu oposto, as trevas, representam a perdição, castigo e morte.

O artista das novas mídias dispõe, hoje, de ferramentas que lhe possibilitam projetar através da luz. E dessa forma, no caso da luz como fonte de emissão ou projeção, o artista controla os dispositivos de luz, trabalhando poeticamente no momento em que confere um sentido à sua obra. Com o passar dos anos, os limites desses dispositivos se dissipam o que permite a interação homem e luz cada vez mais próxima. O reflexo dessa relação cada vez maior com os dispositivos técnicos, propiciou uma abertura crescente da obra: o artista pode trabalhar em conjunto com o espectador / ator na construção de seu sentido. 
Para percebermos como se deu, na arte, o uso da cor como fonte luminosa e a correspondente participação do espectador na construção da obra artística, teremos de voltar atrás no tempo. Dessa forma poderemos compreender o processo do rompimento do pensamento clássico, da mímese - "dois planos do modelo e a imitação" Argan (1992, p.11), - para o pensamento romântico, a "poiesis". A arte ganha autonomia com relação a realidade empírica. A seguir destaco alguns fatos para recompor a base dessa transformação no cenário da história.

Graças a essa transição do clássico para o romântico, os artistas passaram, segundo Argan (1992, p.12), a se interessar por temáticas e abordagens do seu próprio tempo; estreitaram os laços com a ciência, o que permitiu uma prática artistica que incluia a experimentação e a atenção ao espectador. E quando se trata de luz como forma de manifestação artística, a arte invariavelmente está ligada à ciência.

\subsection{Eventos que contribuíram para o encontro entre ciência e arte}

$\mathrm{Na}$ arte, a passagem da era clássica para a romântica ou moderna, teve grande repercussão. Argan (1992, p.14) destaca a transformação das tecnologias da época e a organização da produção econômica, com todas as consequências que comporta na ordem social e política. De acordo com o autor, seria inevitável que o nascimento dessa nova tecnologia industrial colocasse em crise o artesanato e as correspondentes técnicas refinadas e individuais, que reinavam na época o que provocou transformações na estrutura e na finalidade da arte. Foi dessa forma, que a ciência, com novos instrumentos e processos, abalou o cenário da arte. Em função do rápido desenvolvimento do sistema industrial os artistas puderam, segundo o autor, mudar de maneira contínua e, quase ansiosa, as tendências artísticas. Não ficaram para trás das poéticas ou correntes que despontavam, imbuídas de uma forte ânsia de reforma e modernidade.

Esse abalo e o consequente movimento dos artistas em busca de aprimoramento e aprendizado de novas técnicas se notou de maneira bastante clara no momento de criação da fotografia, em 1839. Os artistas assistiram ao surgimento de técnicas que rapidamente tomaram o lugar da arte mimética, assumindo de maneira eficiente e rápida o que os artistas executavam com muito labor e tempo. Foi nesse momento que, segundo Argan (1992, p.79), o problema, causado pelo novo panorama que a fotografia 
trazia para a arte, só poderia ser solucionado mediante a distinção entre os tipos e as funções da imagem pictórica e da imagem fotográfica. Dessa forma, a arte estaria liberta da tradicional tarefa da representação do "verdadeiro", como destaca o autor, e se colocaria na posição de pura pintura, mostrando como se obtém, com procedimentos pictóricos rigorosos, valores de outra maneira irrealizáveis. Valores esses que são sentimentos, emoções, reações psicológicas e subjetivas que supostamente a fotografia não logra exprimir com a mesma amplitude.

\subsubsection{As implicações da fotografia}

A fotografia surgiu acerca de dois séculos atrás e com ela vieram grandes embates no campo da arte. A fotografia, quando surgiu, "pôs de lado" a pintura mimética devido ao seu caráter bem mais funcional, rápido e fiel ao que se retratava.

\footnotetext{
"Pela primeira vez no processo de reprodução da imagem, a mão foi liberada das responsabilidades artísticas mais importantes, que agora cabiam unicamente ao olho. Como o olho apreende mais depressa do que a mão desenha, o processo de reprodução das imagens experimentou tal aceleração que começou a situar-se no mesmo nível que a palavra oral.” (BENJAMIN, 1993, p.167)
}

A fotografia apresentava instantaneamente momentos isolados no tempo, e devido ao seu caráter reprodutível tendia, conforme McLuhan (1974, p.215), a transformar as pessoas em coisas "estendendo e multiplicando a imagem humana em proporções de mercadoria produzida em massa." O processo de elaboração e produção da fotografia incorporou o uso da luz e da química como essenciais. De acordo com McLuhan (1974, p.216), os objetos naturais passam a ser delineados em função de uma exposição intensificada pelas lentes e fixados por meio de produtos químicos.

A grande vantagem da fotografia em relação à pintura era sem dúvida sua precisão, velocidade e baixo custo. Enquanto o artista levaria dias para completar o retrato de uma pessoa, a fotografia faria o mesmo processo em alguns minutos com a vantagem de retratar exatamente o que se via sem perder nenhum detalhe. De acordo com Brik (2008, p.89), nem mesmo o mais talentoso dos pintores conseguiria reproduzir tão fielmente uma imagem real, assim como a máquina fotográfica. 
Nas considerações de Brik (2008, p.89), a pintura resistiu ao aparecimento da fotografia e com a determinação de não se tornar obsoleta. Os artistas tinham consciência do perigo, pois era claro perceber o grande sucesso do novo aparato que surgia. Eles sabiam também, afirma Brik, que não teriam como competir com a câmera no que se refere ao preço e velocidade, pois os materiais envolvidos no processo fotográfico eram mais baratos e nem o mais rápido dos pintores conseguiria terminar um quadro em minutos. Mas a disputa poderia convergir para precisão, e foi assim que eles fizeram. $\mathrm{O}$ autor nos recorda que a fotografia não possuía cores, mas a pintura sim. Nesse ponto de vista, a pintura seria capaz de reproduzir um objeto muito mais fiel à cor, que faz parte do real, enquanto a fotografia não. O grande problema era convencer o público disso.

Em relação à cor na pintura, Brik (2008, p.91) enfatiza que as cores que a pintura reproduz não são idênticas àquelas presentes na natureza. A pintura não pode transpor as cores reais, mas sim copiá-las mais ou menos aproximadamente do que vemos. Neste ponto do trabalho podemos abrir um parênteses e acrescentar aos comentários sobre a cor que a percepção pode variar de pessoa para pessoa, e também de acordo com o tipo de iluminação ou posição espacial do observador em relação ao objeto retratado.

Voltando a Brik (2008, p.91), o artista por mais talentoso que seja, estará preso às estreitas possibilidades de sua paleta de cor pigmento: ao reproduzir imagem colorida, ela perderá a definição real de luz que invade a cena. O problema do artista, do ponto de vista da precisão, se situava na mídia na qual se trabalhava e não a falta de capacidade. Seria necessário um esforço sobre-humano, para conseguir reproduzir com os instrumentos de que dispunha na época: pincel e a tinta para reproduzir qualquer cena.

A fotografia, na época, podia não reproduzir as cores exatamente, mas ela não distorcia o valor e croma do que se via. Os artistas, diante desse fato, partiram para outras alternativas, que não as de precisão, para sobreviver, caminharam em sentido inverso, mas na busca de enriquecer a pintura com novos rumos que a fotografia não poderia seguir. 
Em síntese, o progresso tecnológico atrelado a fotografia exigiu que os artistas deslocassem o hábito descritivo da mimesis para um desenvolvimento interno de sua criatividade. Conforme McLuhan (1974, p.220), os artistas “dedicaram-se à apresentação do processo criativo destinado à participação pública." Podemos dizer que essa mudança de paradigma favoreceu uma prática artística voltada ao ser humano e, abriu caminho para a participação do espectador no fazer artístico.

\subsubsection{As primeiras "tímidas" propostas de fusão entre ciência e cor na arte}

Com o rompimento das regras clássicas para a autonomia da arte relativamente a mímesis, os artistas se interessaram mais pelo que ocorria na ciência. Esse fato se deu, conforme Argan (1992, p.82), com os artistas que fundaram o movimento NeoImpressionista. Trouxeram, ao processo visual e operacional da pintura, fundamentos científicos.

É possível citar diversos cientistas e pesquisadores que, de uma forma ou de outra, influenciaram os trabalhos de uma corrente de artistas que buscavam mudanças em relação à arte clássica da mímesis. No caso específico do uso científico da cor, foram, segundo Argan (1992, p.82), Chevreul, Rood e Sutton, os grandes influenciadores do movimento Neo-Impressionista, com suas pesquisas a respeito das leis ópticas da visão e, principalmente, dos contrastes simultâneos ou das cores complementares. Seguindo esse caráter experimental do uso científico da cor na arte, os artistas buscavam dar às obras uma outra abordagem: fortalecer o vínculo com o receptor. Segundo o mesmo, para que fossem fruídas, as obras Neo-Impressionistas dependiam de que a análise da visão do observador estivesse presente no procedimento técnico, para se alcançar a sensação visual de quem contempla a obra de arte.

Os artistas do movimento Neo-Impressionista passaram a se apoiar em teorias e tratados da cor que, ditados por cientistas, contribuíam a harmonia cromática e sentido lógico do uso das cores. O receptor torna-se o alvo estratégico das propostas artísticas, como personagem agenciador da recriação da obra, como se percebe na descrição de Schapiro (2002, p.224), ao dizer que o quadro nada mais era do que um painel com cores estrategicamente posicionadas para serem "lidas" e interpretadas pelos olhos do observador, que uniriam aquelas cores no cérebro como num fenômeno de síntese aditiva. 
O movimento Neo-Impressionista foi uma continuação do movimento Impressionista, mas com diferentes valores. Iniciou-se, por volta de 1886. A pintura fundada com base nas leis da teoria da cor e da óptica, foi introduzida por Georges Seurat ${ }^{1}$ (1859-1891). Seurat tinha um profundo interesse pelos estudos científicos da cor em voga na época, e através de experimentações introduziu esse estudo em suas obras.

Segundo Dempsey (2003, p.27), divisionismo ${ }^{2}$ foi o nome da técnica desenvolvida por Seurat, fazendo menção às pesquisas de Chevreul (1786-1889) e de outros cientistas daquele período a respeito da lei dos contrastes simultâneos ou das cores complementares. O princípio de contrastes simultâneos de Chevreul - já referido no capítulo anterior - afirmava que, quando a região da retina é estimulada por uma cor, ela produz a imagem sequencial da cor complementar, as cores contrastantes então se estimulam mutuamente. Desta forma se duas cores complementares forem justapostas, ambas irão intensificar-se mutualmente obtendo-se um resultado vibrante aos olhos. Então, apoiado nesse preceito de que a cor se mistura no olho e não na paleta, Seurat em sua obra aplicava pontos de cor na tela em locais estratégicos, a fim de que a mistura desses pontos, a partir de uma distância apropriada, fossem vistos como uma única cor pelo observador.

Percebe-se então uma intencionalidade de o artista fazer do observador um participante ativo da obra. O resultado desse diálogo entre a tela e aquele que a contempla resulta a obra de arte, que estaria incompleta sem a visão e a presença do espectador como constituinte no processo de recriação da arte. Neste caso a mistura aditiva produzida pela retina do espectador era o elemento de ligação entre ele e a obra.

\footnotetext{
${ }^{1}$ No item 3.2.2 deste capítulo, estudaremos as obras divisionistas de Seurat sob o enfoque da participação do indivíduo espectador em relação à obra.

${ }^{2}$ A técnica do divisionismo pode ser também chamada de pontilhismo.
} 


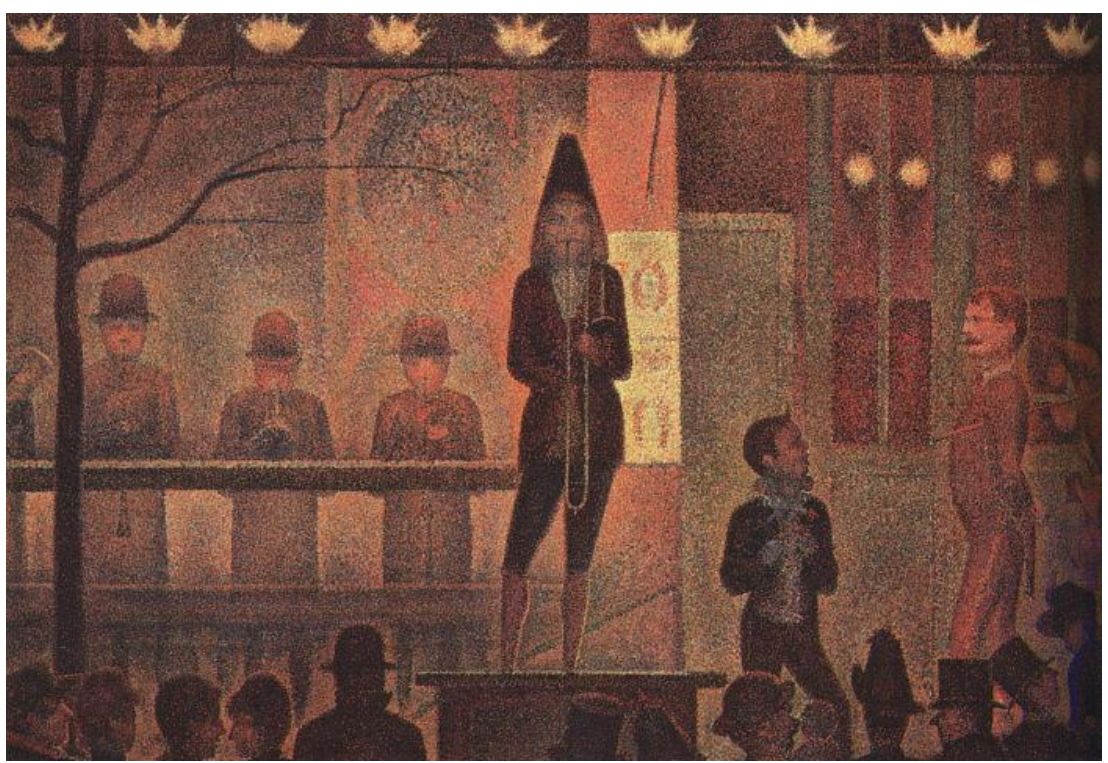

Figura 37: La Parade (1887-88),

Georges Seurat.

Fonte:

〈www.brown.edu>

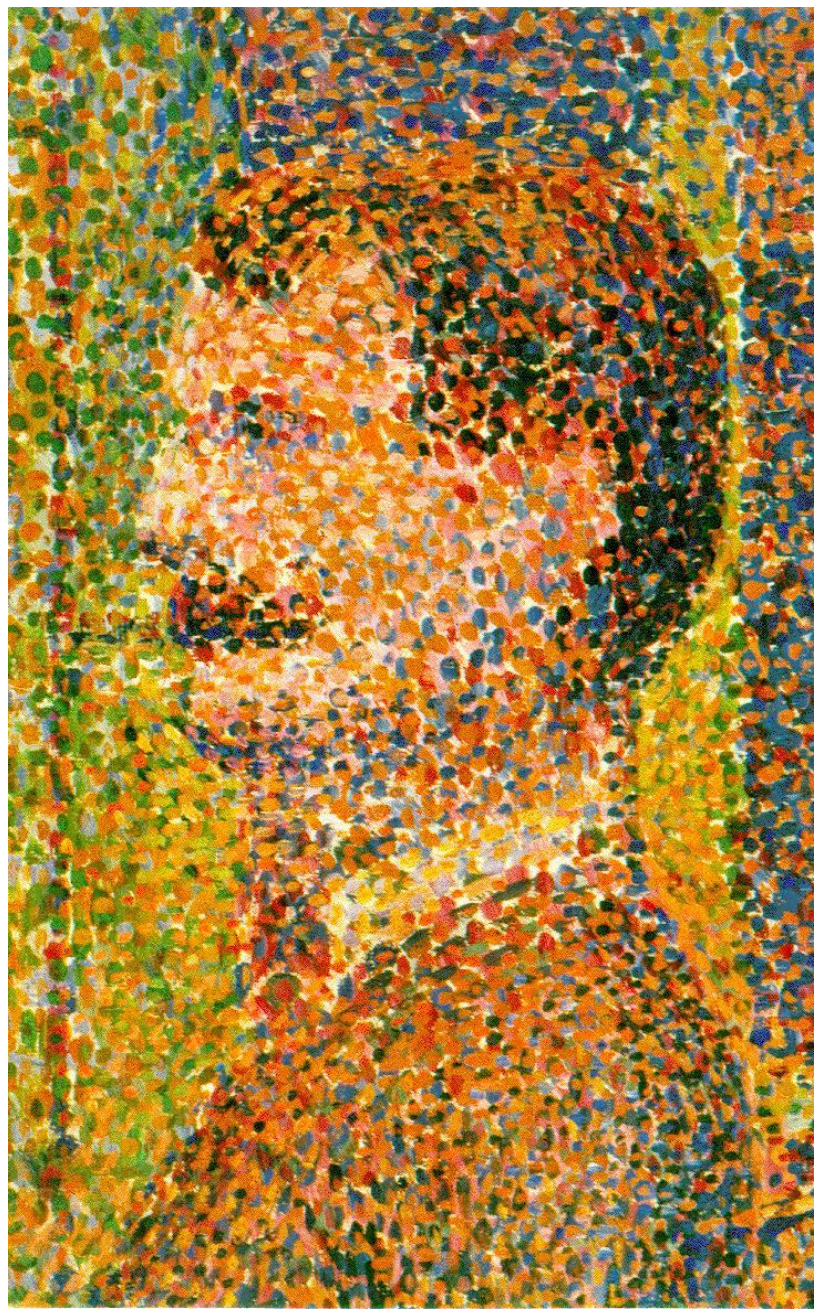

Figura 38: La Parade (1887-88) - detalhe ampliado, Georges Seurat. Fonte: 〈www.brown.edu> 


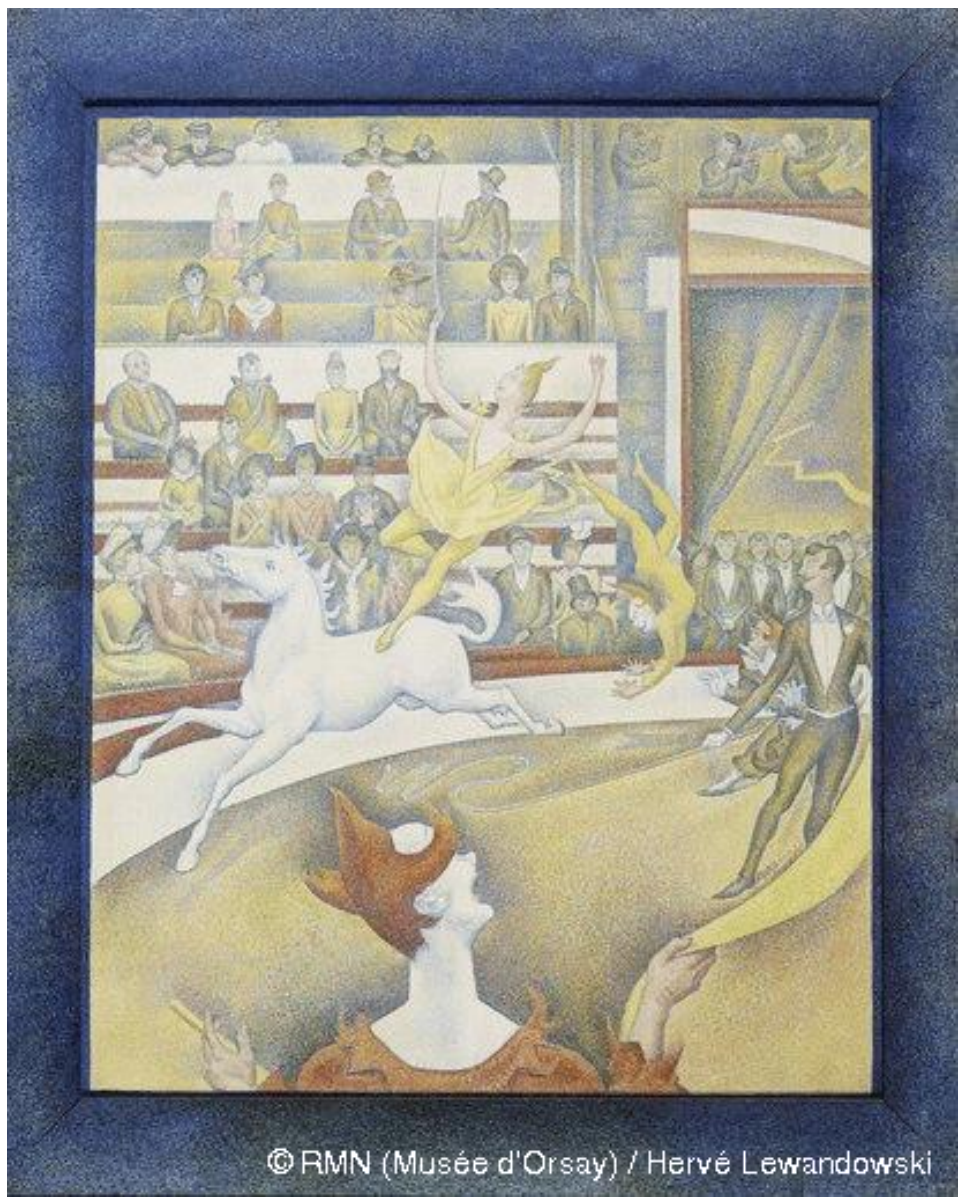

Figura 39: Circus (1890-91)

Georges Seurat.

Fonte: 〈www.musee-orsay.fr>
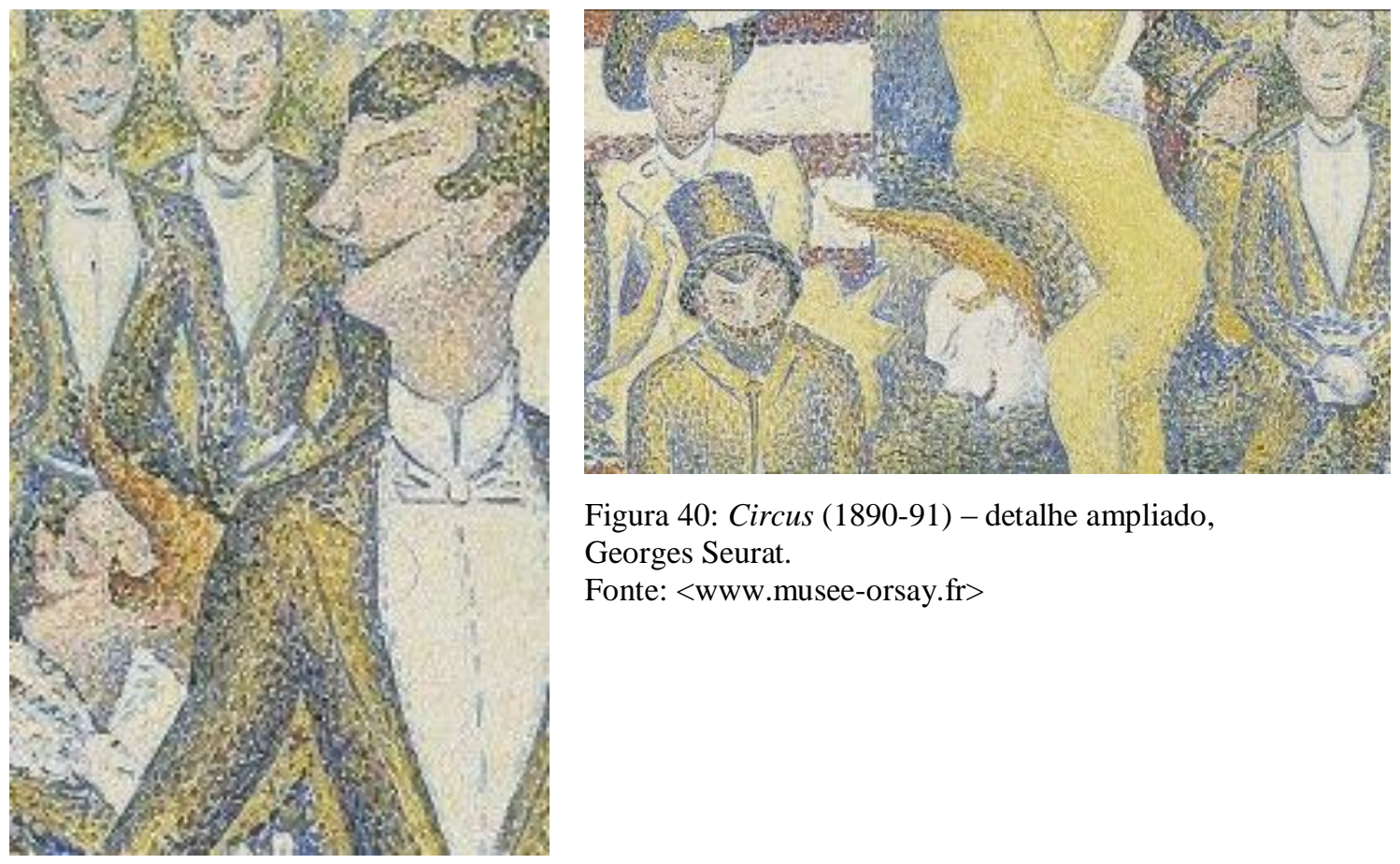

Figura 40: Circus (1890-91) - detalhe ampliado, Georges Seurat.

Fonte: 〈www.musee-orsay.fr> 
A intenção poética de Seurat era a de envolver o receptor na construção visual da imagem; a concretização plena da imagem captada pelo olhar que a configurava se tonava luminosa, vibrante nas cores. Seurat sabia que semelhante efeito não seria possível por meio da tradicional técnica de misturar as cores na paleta (mistura subtrativa), pois o resultado tenderia a escurecer os tons em direção ao preto. Devido ao interesse pela ciência, Seurat transpôs uma descoberta científica para a tela mediante uma mistura aditiva das cores e o auxílio da retina de cada espectador. Assim, ele reatualizaria no processo de contemplar o quadro a poética do artista.

O resultado das obras que utilizavam a vibrante técnica pontilhista era a formação de um movimento cromático que domina os outros elementos da pintura, com base na relação luz e cor (POPPER,1968, p.24).

Os artistas que buscavam o aprimoramento do uso da cor recorriam a tratados científicos recentes para a época e, muitas vezes, dirigiam-se a pesquisadores e cientistas - como foi o caso dos artistas Neo-Impressionistas ao consultarem Chevreul e aplicavam nas respectivas obras conceitos de harmonia de cor e efeitos da óptica. Essa tendência de aliar ciência e arte promoveu mudanças na maneira de produzir a obra. Essa alteração de valores propiciou uma - cada vez mais acentuada - atenção do artista para o espectador.

Dessa forma, entende-se que grande parte das teorias e pesquisas no campo da óptica favoreceram a compreensão do uso e da manipulação das cores, base para a compreensão e a manipulação da cor como fonte luminosa. Contudo, no recorte deste trabalho, sabemos que foi apenas com a eletricidade e o desenvolvimento da tecnologia que o uso da cor, proveniente de fonte artificial, surgiu e suscitou no artista a valorização de uma abordagem científica e tecnológica da cor. 


\subsection{O impacto tecnológico no uso da luz como fonte luminosa}

$\mathrm{O}$ grande progresso tecnológico do século $\mathrm{XX}$ não surgiu repentinamente, foi $\mathrm{o}$ resultado de um constante crescimento no campo científico a partir do século XIX com o surgimento da fotografia ${ }^{3}$ - a que já nos referimos anteriormente. Nessa renovação tecnológica inclui-se o advento da eletricidade que possibilitou manipular a luz como fonte luminosa em lugar do uso de pigmentos. Paralelo a esses avanços, era possível notar uma gradual atenção ao espectador que até então assumira o papel de contemplador passivo não constituinte da obra.

Apesar de podermos rastrear na história o uso de inovações técnicas desde a Antiguidade, foi após a Revolução Industrial, e mais precisamente no final do séc XIX, que é possível notar, de acordo com Popper (1993, p.10), uma influência direta da técnica e tecnologia na arte.

Uma das maneiras de detectar a causa dessa reviravolta nós a definiríamos como uma tendência a repensar a beleza, como o que é fundamental na arte. Muitos foram os artistas que incentivaram a ruptura com o pensamento clássico, frente às opiniões vigentes por meio de seus ideais inovadores. O mais memorável deles, foi o pintor e escultor francês Marcel Duchamp (1887-1968), que "chocou" o comitê julgador da maior exibição de arte em voga na época nos Estados Unidos com sua obra The Fountain (1917) (QVORTRUP, 2003, p.240). Esta obra de Duchamp foi, ainda de acordo com o crítico, responsável pelo surgimento de uma nova era da arte que contestava a beleza e o divino segundo o paradigma romântico, em que o artista era inspirado por Deus. Conforme Qvortrup, a arte deixa sua característica de ser beleza transcedental para dar lugar à interferência do objeto presente e disponível para o uso.

\footnotetext{
${ }^{3}$ De acordo com Popper (2007, p.11), a arte tecnológica possui três principais origens. A primeira é de que a arte tecnológica pode ser rastreada em fontes artísticas como artes visuais, fotografia, cinema, música, arquitetura dentre outras expressões ambientais. A segunda, seria encontrada dentre as fontes técnicas como invenções da engenharia. A terceira origem, seria encontrada nas diversas áreas das ciências humanas e naturais, em particular da física, biologia e linguística.
} 
Essa mudança de pensamento que foi reforçada pela conduta dos artistas no começo do século XX, iria acompanhar o progresso da ciência - como os artistas neo-clássicos fizeram - a fim de dar um novo sentido à arte. Ela deixava de ser simplesmente fruitiva, para estabelecer um elo mais próximo com o espectador, o que reforçava a importância de quem lê a obra. De acordo com Qvortrup (2003, p.242), quando a obra de arte deixa de buscar a beleza divina e metafísica, ela passa a "falar em nome do humano, isto é, que o mundo é visto dentro da perspectiva do observador humano universal”.

"Portadores declarados de um determinismo social e genético, como observado no início do século XX, os seres humanos modernos se colocaram à prova ao supor seu futuro e, assim, investir num programa para mudanças.” (POISSANT, 2009, p.71)

No que concerne à luz e sua importância como fonte de origem da arte tecnológica, Popper (1993, p.12) se refere à Arte Cinética, cuja origem pode ser datada entre 1913 e 1920. Esse gênero de arte se caracteriza pelo movimento e se centra no que se move e no que parece mover-se. Dempsey (2003, p.197) citou uma passagem de Eco no qual o autor italiano afirma que a arte cinética é uma forma de arte plástica na qual o movimento das formas, cores e superfícies é o meio para se obter um todo cambiante. Essa definição, segundo a autora, abrange não somente o tipo mais direto de arte cinética, incorporando o objeto real ao objeto de arte, mas também à variedade de outros tipos:

"[...] A arte que envolve um movimento virtual criado opticamente; a arte que se apóia no movimento do espectador para obter a ilusão do movimento; a arte que incorpora luzes que mudam constantemente. [...]" (DEMPSEY, 2003, p.197)

Os primeiros trabalhos da arte cinética, produzidos por Duchamp, Tatlin e Gabo, utilizavam o movimento mecânico. Na obra Rotary Glass Plates de Marcel Duchamp, ocorre a negação do sentido como forma. O maquinário desenvolvido pelo artista, acionado por um motor faz girarem as hélices coloridas da estrutura numa determinada velocidade, até que a retina do observador não perceba mais nenhuma cor, além do branco. Efeito da mistura aditiva em que o olho soma as radiações de cores, produzindo o branco como resultado. 


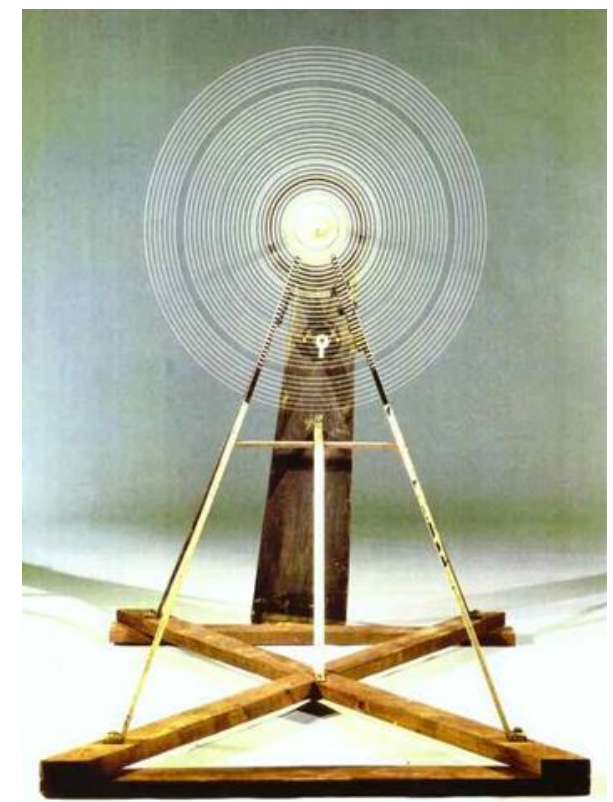

Figura 41: Rotary Glass Plates (1920)

Marcel Duchamp.

Fonte: <www.marcelduchamp.net>

Em todos os momentos da história, a tecnologia e os novos meios decorrentes de descobertas científicas, alteraram o panorama da arte. Os artistas se adaptaram às novas linguagens e desenvolveram suas obras, desfazendo as "[...] fronteiras entre o que é do domínio artístico ou do científico" (DOMINGUES, 2009, p.26). O surgimento de novos materiais trouxe uma nova perspectiva na maneira de lidar com o espectador, o que estreitou os laços entre artista e receptor.

Contudo, foi na segunda metade do século XX que ocorreu um processo de aproximação crescente do sujeito espectador de forma que sua gradual aparição supõe, ao mesmo tempo, seu desaparecimento o que deu lugar a um participante ativo na arte. O sujeito deixa para trás sua característica de sujeito que vê para se tornar o "objeto do olhar" (ROMERO, 2008, p.60).

Assim, de forma a não nos perdermos no vasto cenário de transformações que a arte sofreu ao longo do século XX nos deteremos a partir de agora a enfocar, com maior ênfase, o período a partir da segunda metade do mesmo século ${ }^{4}$, marcado pelo uso da tecnologia na arte e pela consequente, e cada vez maior, solicitação do espectador como participante na criação artística.

\footnotetext{
${ }^{4}$ Foi a partir dos anos cinquenta, que a Arte Cinética manifestou maior impacto. Na área do movimento mecânico, os artistas representantes dessa arte foram Jean Tinguely, Nicolas Schöffer, Pol Bury e Harry Kramer. De acordo com Popper (1993, p.12), os artistas que trabalhavam diretamente com a luz artificial na Arte Cinética foram Gyorgy Kepes, Thomas Wilfred e F. J. Malina.
} 
É a partir deste período, que, de maneira mais explícita, modifica-se o papel do observador em relação à obra, reflexo de uma gradual influência da ciência e tecnologia como meios de expressão e ferramenta criativa na arte. Segundo Plaza e Tavares (1998, p. XV), a partir da década de cinquenta é que encontramos de maneira mais patente os primeiros trabalhos em torno das relações das artes com as tecnologias.

Segundo Popper (1993, p.26), artistas como Agam, Soto, Tinguely e Pol Bury permitiram a participação ativa do espectador em suas obras já no início dos anos cinqüenta. Esses artistas, que experimentavam as formas geométricas, introduziram a terceira dimensão em seus trabalhos ${ }^{5}$, com o objetivo de dar ao espectador uma sugestão ou até mesmo incentivá-los a intervir no processo criativo, fazendo com que o trabalho artístico se efetivasse de modo operativo por parte do espectador. Esse tipo de participação era de ordem óptica ou tátil.

Via-se, portanto, surgir o interesse dos artistas por uma arte que envolvia muito mais uma criação poética por meios mecânicos, deixando-se de lado a expressão estética pela pintura tradicional. A luz era, introduzida pouco a pouco, servindo como forma de expressão desses aparelhos tecnológicos em função de criar uma variedade de movimentos, efeitos de luz, por meio de spots, projetores, lâmpadas de sódio e mercúrio, luzes brancas coloridas, retas, curvadas e até mesmo fluorescentes e néon. (POPPER, 1993, p.17)

Em 1966 na Holanda, foi realizada a exposição Kunst-Licht-Kunst, dedicada ao uso artificial da luz. Essa exposição, de acordo com Popper (1993, p.12), foi marcada pela execução de experimentos tecnológicos com luzes artificiais, ao público feito pelos artistas. Essa exposição foi uma tentativa de incorporar preocupações estéticas ligadas ao "environment", e combinar preocupações no âmbito social com uma tecnologia de ponta.

\footnotetext{
${ }^{5}$ No item 3.2.2. falaremos mais detalhadamente de alguns desses trabalhos.
} 
Essa aparição crescente e descontrolada de novos dispositivos tecnológicos trouxe aos artistas uma gama diversa de novos meios a se explorar, e, de acordo com Malina (2009, p.18), percebeu-se em decorrência disso, - desde os anos cinquenta e sessenta problemas como o acesso a ferramentas o que levou os artistas a buscar parceria com engenheiros e técnicos que dominavam a tecnologia da época. Podemos citar, por exemplo, o E.A.T. (Experiments in Art and Technology), criado em 1967. Para Perissinoto (2000, p.54), um catalisador de atividades inevitáveis que envolviam a indústria, a tecnologia e as artes. Essa associação recrutava engenheiros para dar suporte à criação dos artistas.

O momento, da passagem da arte de processos mecânicos para a arte eletrônica, foi marcado por artistas que, por meio de pesquisas teóricas e práticas, estabeleceram essa mudança (POPPER, 1993, p.20). Dentre eles, podemos citar Yvaral, Yaacov Agam, Nicolas Schöffer, Liliane Lijn, Piotr Kowalski, Wen-Ying Tsai e Stephen Antonakor. Segundo Popper, esses artistas conciliaram a tecnologia com as questões estéticas e deram, de uma maneira progressiva, ênfase às relações entre artista e obra, e por um outro lado, entre tecnologia, ambiente e público geral e de massa. Por outro lado, percebe-se, então, uma transição de ambiente, pois as obras não necessitam mais estar expostas em galerias ou museus. Podem ser acessadas por uma multiplicidade de pessoas, dando-lhes acesso ao tecnológico e à experimentação na arte.

Com as novas tecnologias eletrônicas instauram-se diferentes possibilidades de participação do público na arte. $\mathrm{O}$ artista passa a ter em mãos uma grande diversidade de dispositivos para trabalhar com a luz. Esses métodos tecnológicos continuamente possibilitam o uso na arte que explora o campo sensorial. A participação de quem contempla a arte é potencializada de maneira inovadora e sem limites. Como se constata, desde McLuhan, e como Groys (2008, p.30) salienta, as mídias se tornaram extensões das correspondentes capacidades do corpo humano. Com o passar do tempo, a noção de interatividade passa a ser vislumbrada como consequência de mudanças sociais e tecnológicas; e a expressão da luz firma-se definitivamente com os métodos eletrônicos e até hoje é utilizada. 
Além do mais, progressivamente o uso de materiais, tendendo-se à imaterialidade, o que desperta no receptor uma nova forma de interagir com a obra (POISSANT, 2009, p.72). A cor passa a ser utilizada por meio da luz em instalações e experimentações em todos os meios possíveis, o que desencadeia reações e transmite mensagens ao receptor, numa interação imersiva e reativa.

As cores nas ruas, nos luminosos, em nossas casas, assumem diversos sentidos; o sentido mais forte contudo é o individual. Tal qual um poema, os elementos estão livres o suficiente para favorecerem interpretações as mais variadas. O sentido será o reflexo de nosso próprio background - nossa própria bagagem cultural e existencial. [...] (SANTOS, 2005, p.96)

Foi no último quarto do século XX que, na visão de Couchot (2003, p.155), as tecnologias ligadas ao computador e à informática evoluíram e alteraram o habitus perceptivo da sociedade. No universo tecnológico temos presente diferentes personagens: a informação substitui a imagem e os sinais codificados (bits) substituem os signos que são agora, segundo o autor, manipulados pelo computador, no qual imagens, sons e textos podem se converter em imagens, em sons e mesmo em textos. Percebe-se que essa transformação da arte desencadeou a tentativa de simular a inteligência e o pensamento de maneira artificial e nota-se os efeitos dessa prática crescente na introdução de modificações qualitativas importantes nas relações do público com as informações visuais, sonoras e textuais.

Desta forma sedimenta-se um novo momento na arte em que o computador, juntamente com a estética do século XX, darão bases para a poética digital. Para Romero (2008, p.60) no domínio digital a arte vê o dígito ocupar o espaço do que antes era físico, e percebe serem suas ferramentas substituídas pelos computadores.

Em síntese, esse processo de mudança de linguagem na arte veio acompanhado por um crescente processo de inserção do espectador, desde a participação até a interação e a interatividade. Os artistas produzem suas obras para que o sentido seja constituído pela percepção e pela sensibilidade do público. Isso foi sendo cada vez mais possível e viável com as novas tecnologias. 
A interatividade promovida pelos computadores passa a garantir, assim, a habilidade de implementar complexas estruturas de controle e algoritmo que permitem responder a entradas de informações.

Segundo artigo de Malina (2009, p.18), o enorme impacto tecnológico do microcomputador e, mais tarde, da Internet dominou o desenvolvimento de novas mídias. Os primeiros trabalhos giravam em torno da tecnologia avançada; agora as mídias digitais são onipresentes nas sociedades desenvolvidas.

Embora as novas mídias estejam muitas vezes associadas às mídias digitais, a apropriação artística de todos os tipos de tecnologias úteis levou a uma redefinição contínua das fronteiras das novas mídias (MALINA, 2009, p.18)

Hoje os artistas dispõem de programas de computador e dispositivos tecnológicos que manipulam a cor como fonte luminosa, de forma a integrá-la em sua proposta poética.

Nesse panorama de transformação dos meios tecnológicos e da arte, nós nos deteremos nas particularidades de como os artistas trabalham o conceito de participação em suas obras. Serão apresentados os pressupostos da obra aberta, conceito que busca abranger o processo de inclusão do espectador na obra de arte, quer de forma perceptiva ou ativa. Deste modo, retomaremos momentos na história, da década de cinquenta do século XX, em que artistas tiveram um papel significativo na sedimentação do uso da cor por meio participativo, desde o processo mêcanico e o posterior eletrônico, até alcançarmos o momento presente no âmbito da interação digital.

\subsubsection{Visão geral de algumas premissas (pressupostos) da obra aberta}

O conceito de obra aberta foi ditado por Umberto Eco no ano de 1962, em sua publicação Obra Aberta (1962). O crítico pretendia explicar algo que até então acontecia e mudava continuamente na arte. "Quando não muda o objeto de indagação, mudam os métodos para interpretá-lo" (ECO, 2005, p.16).

Já se via na época de publicação de sua obra, um período de "evolução acelerada" (ECO, 2005, p.16). Para o autor, não se deve adotar preceitos e definições únicos para definir algo em constante mudança. A obra aberta seria uma mensagem 
fundamentalmente ambígua, com uma pluralidade de significados combinados num só significante. Segundo Eco, essa condição é característica de toda obra de arte e tal ambiguidade se torna, nas poéticas contemporâneas, uma das finalidades explícitas da obra.

\begin{abstract}
Visando à ambiguidade como valor, os artistas contemporâneos voltam-se consequentemente e amiúde para os ideais de informalidade, desordem, casualidade, indeterminação dos resultados; daí por que se tentou também imposta o problema de uma dialética entre "forma" e "abertura": isto é, definir os limites dentro dos quais uma obra pode lograr o máximo de ambiguidade e depender da intervenção ativa do consumidor, sem contudo deixar de ser "obra". Entendendo-se por "obra" um objeto dotado de propriedades estruturais definidas, que permitam, mas coordenem, o revezamento das interpretações, o deslocar-se das perspectivas (ECO, 2005, p.22).
\end{abstract}

Eco (2005, p.26) completa suas considerações: a obra aberta não só é uma categoria critica, mas representa um modelo hipotético, embora elaborado com a ajuda de numerosas análises concretas, o que é útil para indicar, numa fórmula de manuseio prático, os rumos da arte contemporânea.

Para esse autor (2005, p.40), a obra de arte é "um objeto produzido por um autor que organiza uma sessão de efeitos comunicativos", de forma que o fruidor possa "recompreender" a obra, a forma originalmente proposta pelo autor por meio do "jogo de respostas à configuração de efeitos sentida como estímulo pela sensibilidade e pela inteligência". A obra não se revela de maneira clara, ela "se abre" ao espectador de maneira dúbia, dando margem para que o espectador a desvele por meio de seu conhecimento dos códigos presentes na obra. A abertura da obra estaria então relacionada às infinitas possibilidades de leitura, fruto do esforço mental do receptor para dar sentido a obra de arte.

“(...) A Obra Aberta (1962), trabalho no qual [Umberto Eco] anuncia que o 'processo interpretativo' representa uma 'forma individual e tácita de execução da obra de arte', sublinhando o papel ativo do leitor ou do ouvinte e transferindo uma parte da criação para o pólo de sua recepção." (POISSANT, 2009, p.75) 
Para esta pesquisa, o conceito da obra aberta servirá para compreender a relação entre obra e espectador. Servirá, por conseguinte, para entender o ponto de vista criativo do artista e a dialética entre a estrutura do objeto como "sistema fixo de relações" e a resposta do receptor como livre inserção, e ativa recapitulação daquele mesmo sistema (ECO, 2005, p.27). Dessa forma, entende-se que o artista dá um sentido a obra, mas não a completa. Pensamos que o papel conferido ao receptor, de constituinte do processo de significação da obra, com base na cor como fonte luminosa, poderia decodificar a mensagem presente na obra artística. Esse foi o objeto da pesquisa que resulta nesta dissertação.

De acordo com Eco (2005, p.50-51), existem dois tipos de "abertura" de uma obra. Uma delas, a de participação mental, "baseada na colaboração teorética, mental do fruidor, o qual deve interpretar livremente um fato de arte já produzido, já organizado segundo uma completude estrutural (ainda que estruturado de forma a tornar-se indefinidamente interpretável)", nesse caso a obra já estaria "acabada". A segunda - e que veremos mais para frente - seria a obra em movimento que permite uma participação manual e ativa do receptor e que de acordo com o autor seria relativo aos "objetos artísticos que trazem em si mesmos como que uma mobilidade, uma capacidade de reproduzir-se caleidoscopicamente aos olhos do fruidor como eternamente novos."

Em referência à proposta de Eco e do que denominaremos participação mediada corporal(mente $)^{6}$, no contexto deste trabalho, iniciaremos o exame a partir das obras que solicitavam do espectador uma atenção e participação primordialmente perceptiva (mas que possa também requerer a movimentação física por parte do receptor), mas sem que com isso altere-se a estrutura da obra que, no entanto, é dependente dessa percepção que lhe dá sentido. Trataremos ainda da participação mediada automaticamente e instantaneamente ${ }^{7}$. Neste caso, o participante é solicitado a intervir na estrutura da obra,

\footnotetext{
${ }^{6}$ Optamos por esta denominação, visto que em algumas obras a serem apresentadas não só a participação mental, mas também a corporal são intrínsecas para a construção dos vários sentidos da obra. Assim sendo, proporemos que a participação mediada corporal(mente) pode também se dar a partir de duas categorias. No primeiro caso, vinculada à noção de obra aberta, em que esta encontra-se fisicamente realizada. No segundo, relativa a noção de obra em movimento em que a obra está em constante modificação estrutural.

${ }^{7}$ No item 3.2.3., com base em Tavares trataremos dos três diferentes tipos de participação (a participação mediada corporalmente, automaticamente e instantaneamente) proposta pela autora no âmbito da obra em movimento.
} 
alterando sua forma. Se, no primeiro caso, a obra mostra-se finalizada sob o ponto de vista de seu programa poético, no segundo, a intenção proposta pelo artista é dispô-la física e estruturalmente aberta para incorporar diferentes possibilidades de transformação. Em ambos os tipos de participação procurou se destacar as obras que utilizaram a cor na relação dialógica com o receptor.

\subsubsection{Da obra aberta à participação mediada corporal(mente)}

A obra aberta, cuja participação solicitada é mental, requer a ação complementar do receptor no momento de fruição da obra. O receptor contribuirá na leitura dos códigos imanentes à obra, valendo-se de sua consciência de linguagem. Como resultado, a interpretação da obra será singular. Essa participação se tornou mais efetiva no momento da crise do objeto artístico tradicional, e fez surgir condutas poéticas que "trouxeram fôlego para pensar-se a criação fora dos valores estabelecidos pela pintura retiniana" (TAVARES, 2000, p.45).

"Obra aberta como proposta de um "campo" de possibilidades interpretativas, como configuração de estímulos dotados de uma substancial indeterminação, de maneira a induzir o fruidor a uma série de "leituras" sempre variáveis; estrutura, enfim, como "constelação" de elementos que se prestam a diversas relações recíprocas." (ECO, 2005, p.150)

O receptor, de acordo com ECO (2005, p.50), então interpreta um objeto "já produzido" e "já organizado segundo uma completude estrutural" cujo conteúdo se apresenta de modo ambíguo.

Ao tratar desta participação mediada corporal(mente), abriremos uma excessão no recorte até agora proposto de apresentar apenas os fatos históricos ligados à segunda metade do século XX e relembraremos, de modo sincrônico, a importância do movimento Neo-Impressionista - já referido. Por ser o movimento Neo-Impressionista um marco na sugestão de o espectador colaborar na produção da obra, retornaremos ao final do século XIX e início do século XX para relembrar, no contexto da participação mental, estudado neste item, como as obras de Seurat contribuíram para a inclusão do receptor na arte. $\mathrm{O}$ uso da cor nas obras, a seguir apresentadas, foi feito pelo uso do pigmento, mas já assumiram um caráter inovador: desvincularam-se das tradicionais 
técnicas de pintura e migraram para um uso consciente e sutil de vincular o receptor na arte. O uso da cor como fonte luminosa e o consequente domínio da luz permitiram uma crescente solicitação do receptor, mais participativa e perceptiva no contato com a cor.

A técnica divisionista de Seurat marcou o movimento Neo-Impressionista. Foi uma tentativa de aplicar na arte leis da ciência que envolviam o uso da cor e da luz. A obra, finalizada e completa, abria-se ao receptor para que pudesse recriá-la, "vendo" o quadro de maneiras diversas, dependendo de seu posicionamento físico, o que lhe permitiria acessar a obra de um modo distinto. As cores-pigmento eram aplicadas de tal forma no quadro que dependiam inteiramente da retina do observador para se formarem. A colaboração do receptor era sugerida mediante procedimentos compositivos.

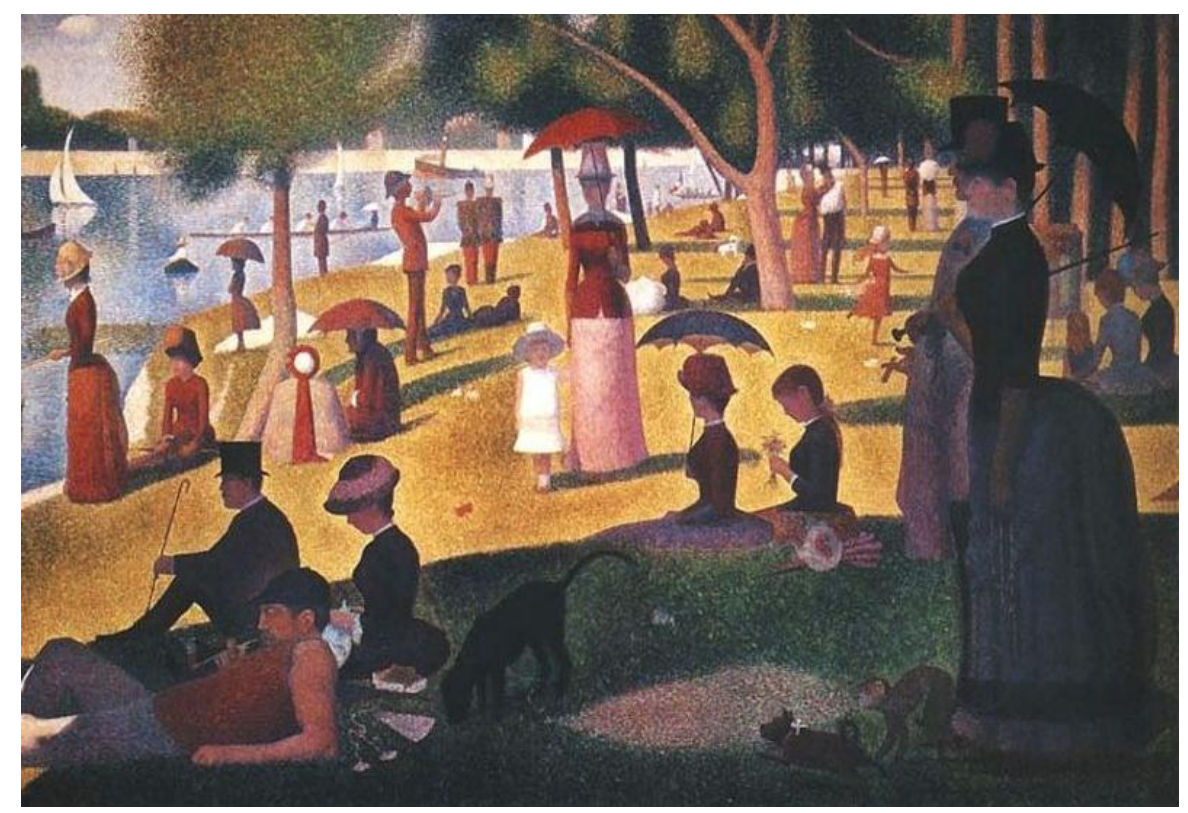

Figura 42: Sunday afternoon on the island of La Grande Jatte (188486)

Georges Seurat. Fonte: $<w w w . g e o r g e s s e u r a t . o r g>$

A distância necessária para que o espectador pudesse perceber o efeito da mistura óptica dos pontos aplicados na tela exigia um afastamento, que permitisse aos olhos do observador ter dificuldade para identificar os tons de cada pincelada. O esforço dos olhos do observador para manter o detalhamento da imagem à medida em que se afastava da tela causaria uma mudança de foco de efeito vibrante e luminoso, que promovia uma sensação de movimento (GAGE, 1999, p.215). 
"A carefully mounted mechanical system allows its beating and rumbling to be sensed deep down below the rustling of the surface. The spectator is unconsciously affected by this architecture in motion which disturbs him without him being able to decipher the complex rhythm. It is like the way in which the mechanics of breathing and blood circulation lie hidden behind the epidermis of every living form." ${ }^{\prime 8}$ (LHÔTE, APUD POPPER, 1968, p.23)

Essa distância, que o espectador deveria encontrar quando estivesse diante da obra para obter a sensação cromática da mistura aditiva, seria de acordo com Gage (1999, p.215), ao citar Pissaro, uma distância de aproximadamente três vezes a diagonal do quadro. Desta distância as cores tenderiam a se fundir na retina, do espectador/participante, que percebe a obra diferentemente do que ela é fisicamente. Existe também, para o autor, uma variedade de formatos relativos à pincelada dos pontos presentes na tela por Seurat. Ao retratar uma imagem, o artista utilizava uma certa espessura de pontos mais larga, mas à medida que a imagem era captada em seu contorno, era possível perceber que os pontos diminuíam e tornavam a imagem mais precisa, quando vista a uma certa distância.
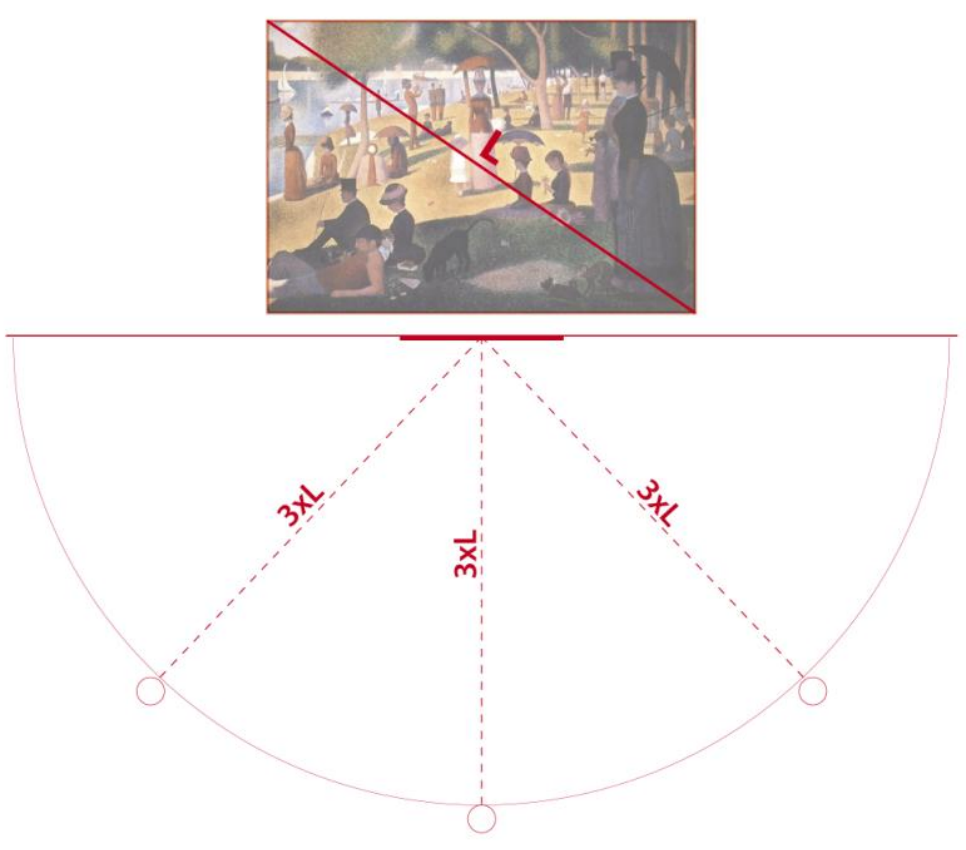

Figura 43: Gráfico que aponta a distância média para se perceber a fusão dos elementos cromáticos de uma obra pontilhista de acordo com Pissaro.

Fonte: gráfico da autora de acordo com relato de Pissaro (GAGE, 1999, p.215)

\footnotetext{
8 "Um cuidadoso sistema mecânico montado permite sua vibração e tremulação luminosa a ser sentida profundamente abaixo do ruído de sua superfície. O espectador é inconscientemente afetado por esta arquitetura em movimento que o perturba sem dar a ele a chance de decifrar seu complexo ritmo. É como o modo em que a mecânica da respiração e da circulação sanguínea se encontram escondidos por trás da epiderme de toda forma de vida." (T.A.)
} 
Para exemplificar o efeito vibrante das cores aos olhos do espectador, basta analisarmos um pequeno trecho de representação de grama da obra Sunday Afternoon on the Island of la Grande Jatte (1884-6), em apenas alguns centímetros quadrados de grama representada, perceberemos uma grande quantidade de pontos pequenos que são responsáveis pela representação do verde da grama. Em uma análise feita por Fénéon, crítico e amigo de Seurat, e transcrita por Gage (1999, p.210), descreve-se como o artista em alguns centímetros de grama, justapunha as cores de modo a representar uma tonalidade vibrante aos olhos do espectador. Nesta pequena área, em meio aos pontos verdes predominantes da grama, estavam espalhados pontos laranjas que seriam responsáveis por expressar a ação da luz solar, por volta das quatro horas da tarde, horário em que se representa a cena.

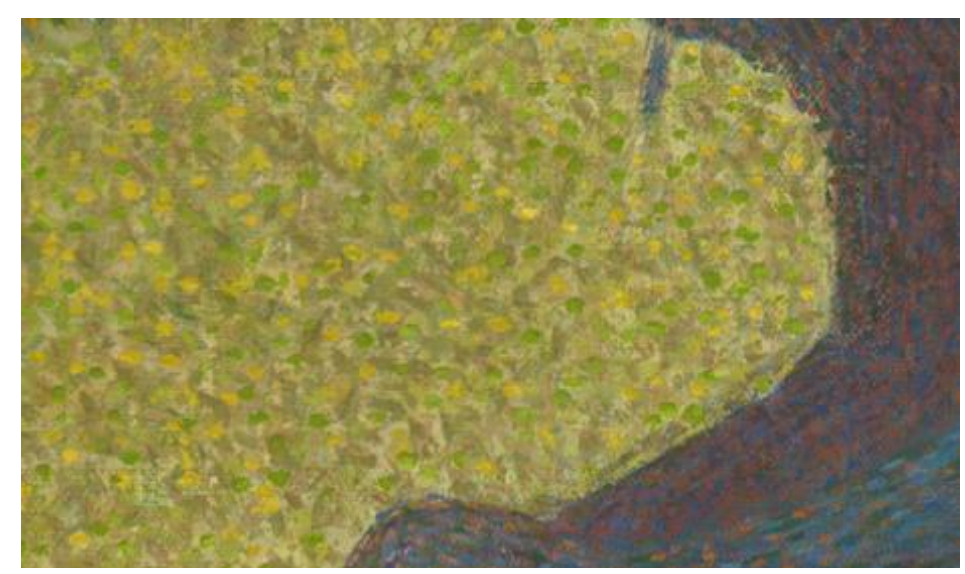

Figura 44: Sunday afternoon on the island of La Grande Jatte (188486) - detalhe Georges Seurat. Fonte: <www.cis.rit.edu>

Percebemos na obra neo-impressionista de Seurat, uma tentativa de se unir à ciência, e com essa mudança de paradigma, Seurat acaba indiretamente (ou não), abrindo portas para a inserção do espectador como participante ativo na obra. É com essa participação perceptiva, graças à presença do espectador, que a obra completa o seu sentido.

Depois desta degressão, em que nos distanciamos da sequência cronológica a que nos propusemos, voltaremos à segunda metade do século $\mathrm{XX}$, em que a relação entre a arte e a ciência se consolidara: ambas caminhavam em direção ao aprimoramento da tecnologia. 
Podemos associar com à participação mental algumas obras do movimento Op $\mathrm{Art}^{9}$ que, segundo Dempsey (2003, p.230), empregou fenômenos ópticos para confundir os processos normais de percepção. Tanto os padrões imprecisos em preto e branco, como as justaposições de cores em tonalidades fortes, que vibram, ofuscam e oscilam, com efeitos de ondulação, ilusão de movimento ou pós-imagens. Para Dempsey (2003, p.232), a Arte Op necessita da participação do receptor para completá-la. Nesse sentido, as criações são obras "virtuais" que estimulam o espectador a refletir sobre os processos de percepção e pensamento e a questionar a natureza ilusória da realidade. Com isso parecem excessivamente cerebrais e sistemáticas, mais próximas da ciência do que das humanidades.

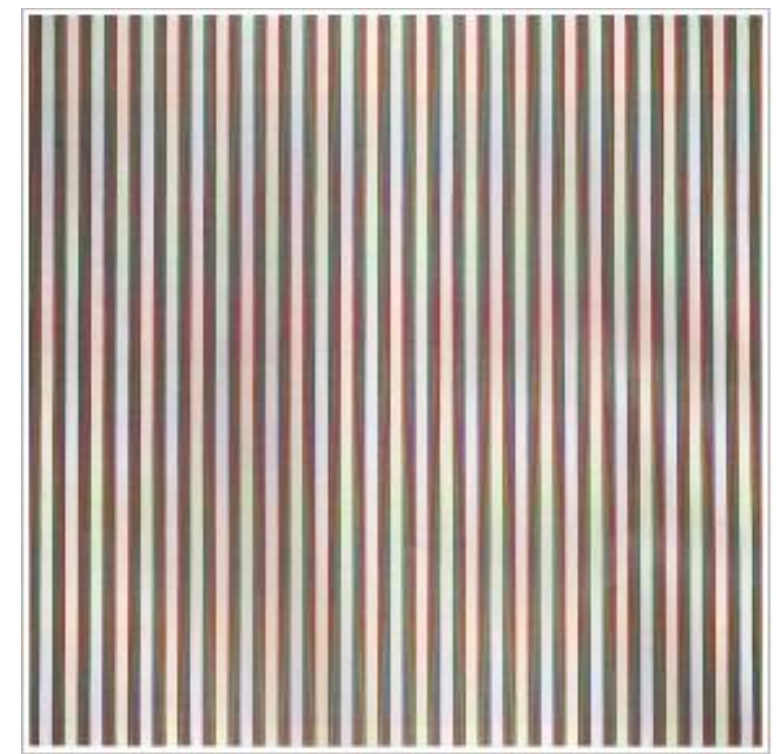

Figura 45: Zing 1 (1971) Bridget Riley. Fonte: 〈www.op-art.co.uk>
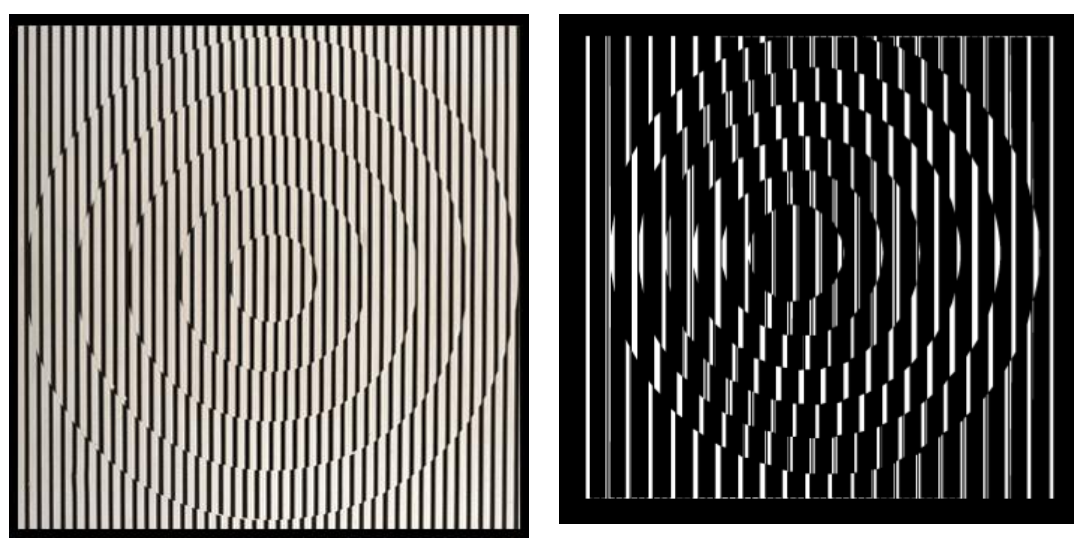

Figura 46:

Aceleração Óptica

(1965)

Victor Vasarely

Fonte:

<www.yvaral.org>

\footnotetext{
${ }^{9}$ Salientamos que o movimento Op Art não se caracterizava por apenas trabalhar com obras "finalizadas". Mas a título de exemplificar determinadas obras que exigiram do espectador a participação mental, faremos menção a elas no contexto histórico-cultural em que se produziram.
} 
As obras da OpArt são reconstruídas e atualizadas no ato perceptivo do receptor e é "prolongado e conduzido pelas inesperadas dificuldades, intrínsecas ao estabelecimento das associações." Nota-se nestas obras, um prolongamento do ato de percepção, juntamente com uma proposta, de "instaurar a qualidade dinâmica que provoca sensações ilusórias no receptor." Esse tipo de ilusão é aquele onde, "os processos normais de visão são colocados em dúvida, por meio de fenômenos óticos inerentes à estrutura da obra" (TAVARES, 2000, p.56).

Para Perissinoto (2000, p.18), a maioria das ilusões ópticas, associadas ao movimento, se produzem quando nosso sistema de percepção oscila entre várias soluções. A mesma autora exemplifica esse fato ao relatar a ambiguidade nas formas percebidas como figura e fundo. Afirma que nosso sistema de percepção oscila rapidamente e em alguns casos a figura chega a atingir uma "definição espacial".

Na figura 45, que representam a obra Zing 1 (1971) de Bridget Riley e na figura 46 referente à Aceleração Óptica (1965) de Yvaral, notamos a característica dos artistas de querer transmitir uma sensação de movimento e instabilidade com estranhamento obtidos pela alternância de elementos geométricos, cores, linhas e do moirée. Assim como no movimento cinético, o espectador reconhece um movimento inexistente no corpo físico e estrutural da obra.

É necessário destacar que no que se refere à participação mental, por meio da percepção visual, a Arte Op e a Arte Cinética ${ }^{10}$ possuem vários pontos em comum. Nesse caso, nos referimos a obras que visam provocar a sensação de movimento sem para isso utilizar meios mecânicos. Os casos aqui representados se caracterizam por utilizar grafismos que visam iludir a visão do receptor por meio de efeitos ópticos.

Essa ilusão que se constitui a partir dos olhos do espectador, pode ser explicada, como resultado de fatores, como a iluminação, o contraste e até de fatores ligados a condições de fadiga da retina. Desta forma, a imagem pode ser distorcida por engano dos sentidos, e produzir a ilusão. Ainda de acordo com o autor na área da ciência, o estudo das ilusões

\footnotetext{
${ }^{10}$ De acordo com Tavares (2000, p.60-61), “enquanto os artistas cinéticos tiram partido do movimento como elemento de transformação, a Op-art trabalha sob o meio pictórico, destacando o jogo de linhas e cores. Diferem, portanto, no método e na intenção".
} 
ópticas existe há pouco mais de cento e cinquenta anos e constitui um fenômeno possivelmente oriundo de imperfeições ópticas, ou teria origem nas "interpretações intelectuais" realizadas pelo córtex cerebral de cada observador. (FARINA, 2006, p.40)

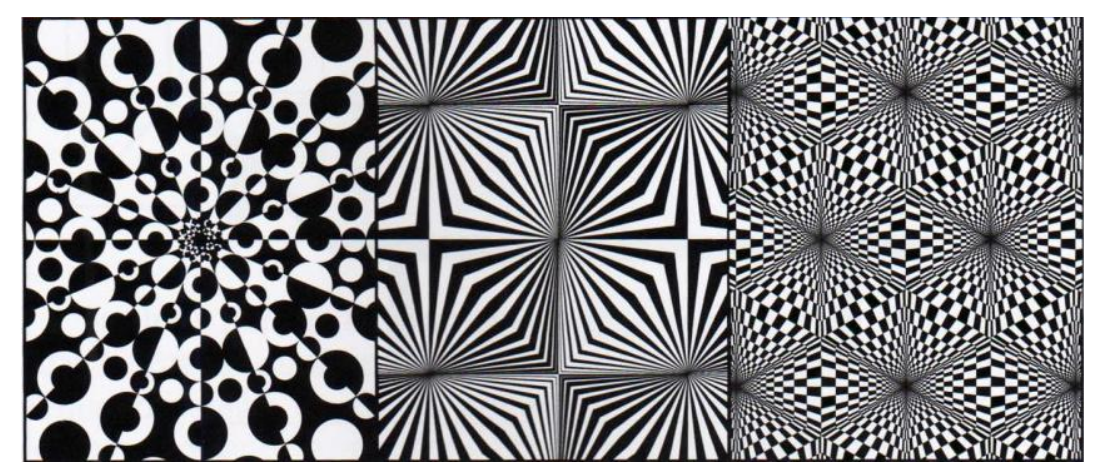

Figura 47: Grafismos cinéticos da obra Geometrical and Optical Art de Jean Larcher. Fonte: (FARINA, 2006, p.46)

Em algumas obras pertencentes ao movimento da Op Art e da Arte Cinética é possível notar o que Farina (2006, p.46) classifica como ilusões fisiológicas de movimento, causadas por processos retinianos ou por problemas nos centros visuais. Experiências foram feitas, no passado, para investigar mais profundamente esse efeito ilusório nos olhos. O autor relembra a experiência feita por Fechner em 1838, em que, ao rodar um disco com uma metade branca e a outra metade preta, surgia uma variedade de anéis concêntricos coloridos, em que essas cores variavam de acordo com a velocidade da rotação. A explicação para esse efeito, de acordo com Farina (2006, p.46), se deve ao fato de a luz branca produzir cansaço aos olhos, os "elementos discriminadores de todas as cores ficam afetados" por ser o branco a resultante da união de todas as cores. Desta forma, a estimulação destes "discriminadores" estabelece uma relação com o comprimento de onda para cada cor estimulada. O vermelho, na qualidade de onda mais longa, é sentida mais rapidamente, se comparada às ondas mais curtas, da faixa cromática do roxo.
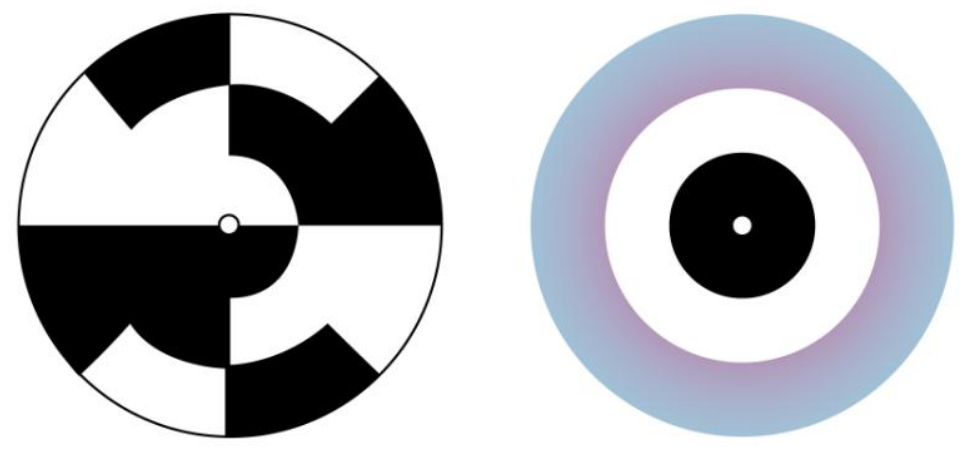

Figura 48: Construção gráfica que representa a ilusão fisiológica. Fonte: Ilustração baseada em Farina (2006, p.46) 
Agam foi outro artista que produziu obras que exploravam a percepção visual. No caso da obra Monochrome Blue and Color Rhythm Polymorph, que Agam fez em homenagem a Yves Klein ${ }^{11}$, o azul se dissolve em uma "fusão sinfônica“ que, de acordo com Aragaki (2007, p.76), absorve a cor, a forma e o ritmo. Por meio da distribuição das cores e formas, Agam queria propiciar ao receptor uma experiência mais profunda de se "sentir" o azul de várias maneiras, o que um quadro plano não poderia fazer. Pois, conforme o crítico, posicionado de um lado, o espectador via um azul monocromático e, do outro, era possível ver listras nas cores azul e branco, e dos outros incontáveis ângulos de visão entre os dois extremos é possível ver uma rica variação de cores espectrais com o azul presente e diluído no total.

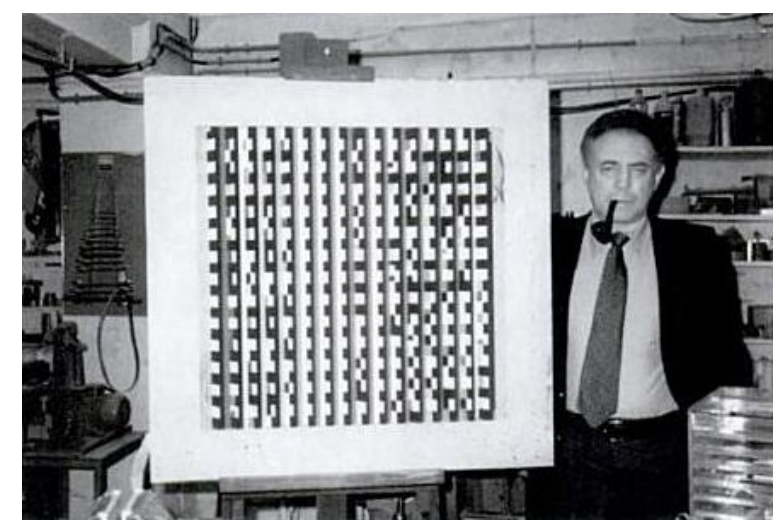

Figura 49: Monochrome Blue and Color Rhythm Polymorph, Yaacov Agam.

Fonte: (ARAGAKI, 2007, p.76)

Neste caso, a participação privilegia o envolvimento do receptor na obra tanto pela mediação mental quanto por meio do corpo, instaurando relações de experimentações que visam atualizar diferentes possibilidades de ação presentes na obra. A estrutura polimórfica de sua obra só revelaria sua estrutura, se o espectador se deslocasse diante dela.

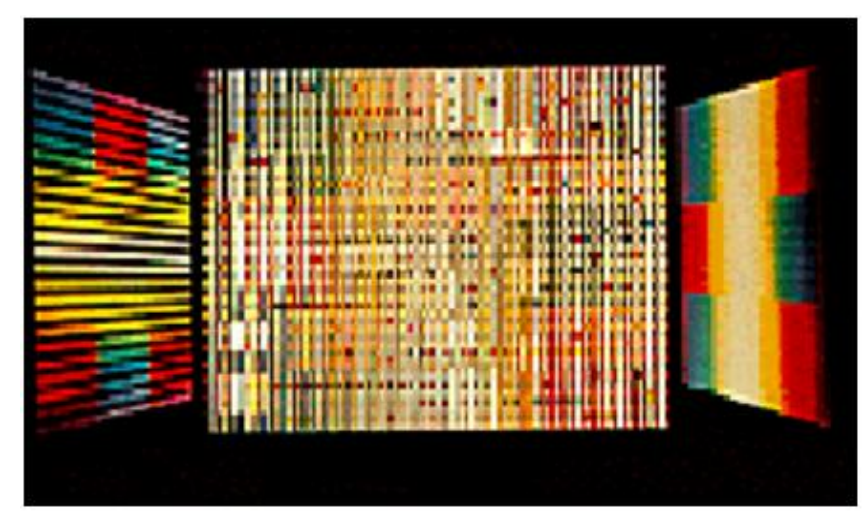

Figura 50: Nouveau solfège 1966, Yaacov Agam.

Fonte: (PERISSINOTTO, 2000, p.28)

11 A homenagem a que Agam se referiu foi ao quadro Klein Blue de Yves Klein. 
Na figura 50, podemos ver representado o efeito que a obra Nouveau Solfêge (1966) provoca no participante quando se desloca em um determinado raio a uma certa distância da obra. A maneira como Agam trabalhou a superfície da obra, explorando diferentes relevos e cores, promoveu a alteração da percepção do observador à medida que se deslocasse em relação à obra. A cor com diferentes suportes artesanais procura aproximar o espectador, instigando-o a examinar a obra, e com ela tecer experiências.
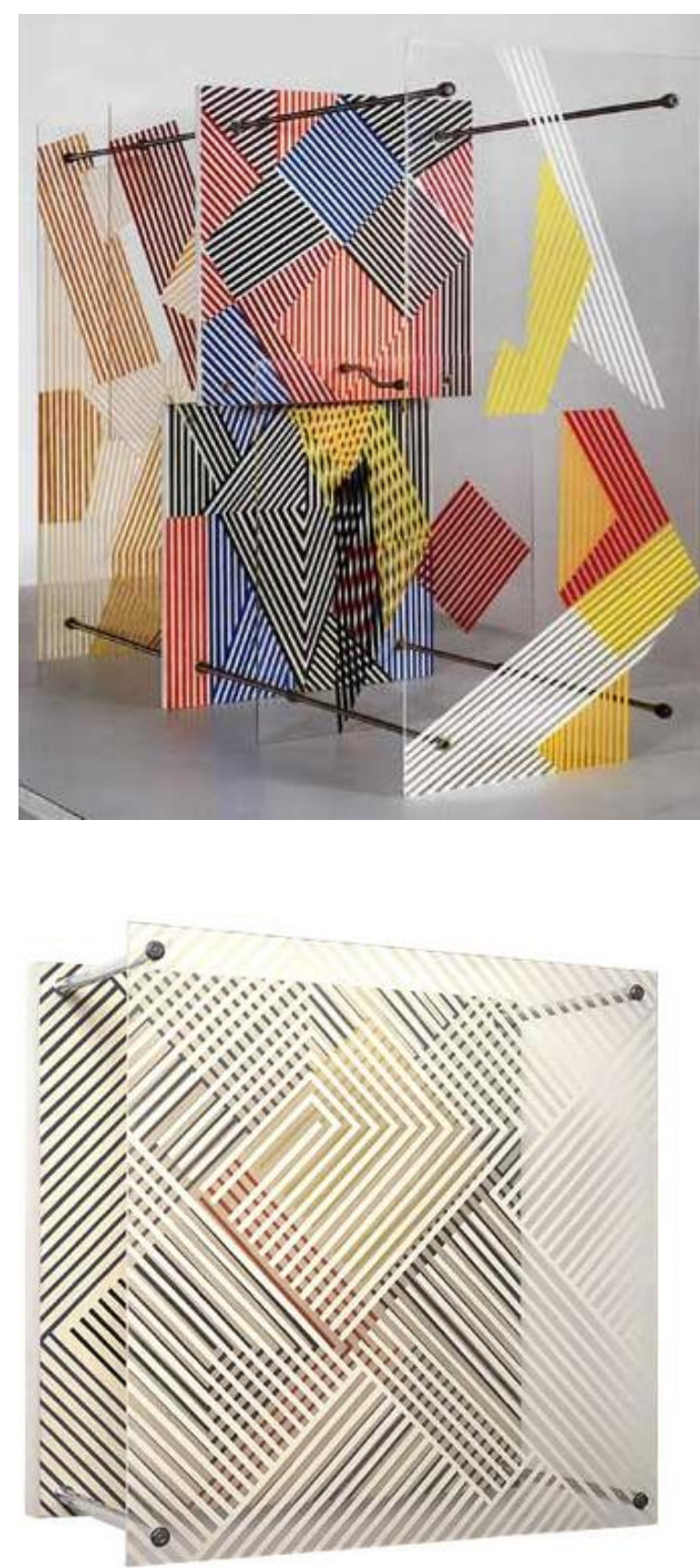

Figura 51: Harmonie transformable (1956) Jésus Rafael Soto.

Fonte: 〈www.jr-soto.com>

Figura 52: Structure Cinétique (1955)

Jésus Rafael Soto.

Fonte: <www.jr-soto.com> 
As obras de Jésus Rafael Soto desencadeiam um tipo de vibração por meio da repetição de elementos formais, além de utilizar o efeito moiré. Percebemos, nas obras de Soto, o uso das cores para acentuar a ilusão de óptica.

Soto utilizava meios analógicos para produzir uma noção de ambiente virtual que, de acordo com Weibel (2009, p.107), muda conforme o posicionamento do espectador.

De acordo com Perissinotto (2000, p.23), Soto mistura todos os efeitos ópticos visando fazer da presença física do espectador uma "condição não alienada da existência vulnerável da obra". Desta forma, o movimento do espectador em relação à obra seria a de percepção do estado visual e luminoso da obra de arte. Essa posição é o fator que proporciona uma visão diferente segundo o ponto de vista do observador. Em síntese, para Soto o espectador é componente de sua obra: o posicionamento do espectador condiciona a visualização dos efeitos da obra (PERISSINOTO, 2000).

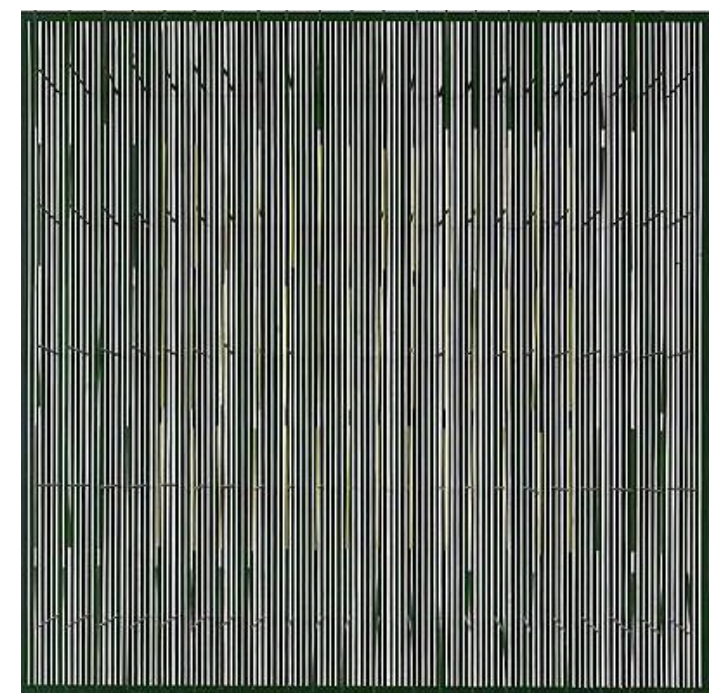

Figura 53: Verde Hélène (1976) Jésus Rafael Soto. <Fonte: www.jr-soto.com>

A seguir, serão apresentadas obras em que é possível identificar a participação do receptor na estrutura da obra. Em nossa análise, usaremos os conceitos das poéticas da participação, de Tavares, em que o espectador, além de participar da construção do sentido, ele completa uma obra fisicamente inacabada. Desta forma, se acompanharmos o progresso tecnológico e sua interferência no âmbito artístico, perceberemos como o receptor foi ganhando espaço graças ao uso de equipamentos mecânicos que futuramente se deslocariam numa escala cronológica, assumindo a tecnologia eletrônica e, finalmente, a digital. A cor acompanhou esse processo. A princípio por meio de 
pigmentos e por meio luminoso, no estágio mecânico e eletrônico. Nesse caso, o uso da cor como elemento comunicativo e representativo foi considerado por alguns artistas fundamental. Nós nos deteremos especialmente na passagem das diferentes formas de inserção a partir do conceito de obra em movimento.

\subsubsection{Da obra em movimento às participações mediadas corporalmente, automaticamente e instantaneamente}

A influência das transformações científicas, técnicas e sociais aliadas às mudanças na revolução da linguagem artística, próprias de uma civilização tecnológica, evidenciam novas artes, que passam a ser lançadas ao público, o que resultou em "deslocamentos no que tange às relações entre produção/obra/recepção" (TAVARES, 2000, p.50).

Tavares (2003, p.41) indica que as possíveis interpretações de uma obra se concretizam na relação artista e receptor, propiciada por diferentes meios e consubstanciada na própria obra enquanto mensagem.

\footnotetext{
"Independentemente da prática artística adotada, o criador, ao utilizar códigos diversos, envia uma dada mensagem que, ao ser transmitida por meio de um canal, é decodificada pelo receptor. Com base nessa dinâmica, evidencia-se um espaço de diálogo entre criador, obra e receptor" (TAVARES, 2003, p.41)
}

No âmbito das obras abertas, a arte que estimula uma participação corporal constitui uma categoria mais restrita de obras. E pela "capacidade de assumir diversas estruturas imprevistas, fisicamente irrealizadas, poderiamos definir como 'obras em movimento' ". (ECO, 2005, p.50-51)

A obra em movimento mostra-se como "reconstrução variável da sua própria estrutura", o que permite uma "multiplicidade de diferentes organizações, passíveis de serem efetivadas no momento de sua execução". Na obra em movimento, além de participar perceptivamente da obra, o espectador tem acesso à construção do objeto artístico: intervém na atualização e nela imprime diferentes formas de aparição. Em outras palavras, a obra em movimento permite ao receptor lidar com "múltiplas possibilidades que, ao serem efetivadas, vão pouco a pouco delimitando a própria obra", norteando-o, imprevisivelmente, para novas alternativas a cada experimentação (TAVARES, 2000, p.70). 
Além de atuar de modo sensível, espera-se deste receptor, conforme Tavares (2000, p.71), que ele conheça os "códigos para que afinal efetive, no trato com a linguagem, a continuidade do processo de recepção." Desta maneira, o receptor pode colaborar e atuar na estratégia proposta nos moldes sugeridos pelo artista. A relação entre o receptor e a obra é tão imprevisível que pressupõe indeterminação no ato de construção da obra.

$\mathrm{Na}$ noção de obra em movimento, o comportamento ativo do receptor faz emergir um "novo ambiente", que para Tavares (2000, p.72), "configura-se estruturalmente pela perspectiva de propor e assegurar ao receptor a possibilidade de exercer uma atividade polissensorial espontânea". Este novo ambiente pretende aproximar o espectador da obra, utilizando novos materiais e privilegiando, de acordo com a autora, a “desmaterialização e desaparecimento do objeto artístico tradicional." Desta forma, nota-se nas poéticas de participação uma tendência crescente de estreitar a distância entre a criação e o receptor por meio da obra que se configura como diálogo aberto à comunicação.

Para o estudo da inserção do receptor, iremos adotar as categorias propostas por Monica Tavares na tese de doutorado: A recepção no contexto das poéticas interativas (2000), nas quais a autora admite que a obra em movimento incorpora três diferentes categorias de participação vinculadas diretamente ao tipo de mediação utilizada entre obra e receptor. A primeira é a participação mediada corporalmente; a segunda, a participação mediada automaticamente, e a terceira, a participação mediada instantaneamente. É importante destacar que tais categorias não são excludentes, e, em específico, permitem rearranjos e combinações entre materiais e procedimentos, ampliando assim, os limites entre passado, presente e futuro (TAVARES, 2000, p.74).

Conforme a autora (2000, p.73), essas três formas de participação são consideradas em referência às técnicas e tecnologias (artesanal, industrial e eletrônica), admitidas como elemento que interpõe a obra entre o receptor e o mundo.

As duas primeiras formas de mediação dizem respeito respectivamente à inserção do receptor por meios artesanais e industriais; a terceira, diz respeito ao uso da tecnologia eletrônica e numérica. Dos três diferentes meios de participação, o que mais nos interessa é a Participação Mediada Instantaneamente por abarcar o objeto de estudo da 
presente pesquisa no âmbito das Novas Tecnologias da Comunicação. Por este motivo ela será posteriormente ao longo deste capítulo estudada mais a fundo de maneira a compreendê-la melhor em seus diferentes aspectos.

O uso da cor como fonte luminosa só se consolidará, com a Participação Mediada Automaticamente. Isso por se tratar de uma tecnologia que envolve emissão de luz e mecanismos que dependem de técnicas mais complexas. Nesse sentido, a cor como fonte luminosa só se destacará no final das categorias de participação já apresentadas. Faz-se importante, agora, conhecer o panorama dos tipos de participação que caminharam na direção do instantâneo.

\section{Participação mediada corporalmente}

Ao falarmos de participação mediada corporalmente na obra em movimento, soma-se o envolvimento que até então era de ordem cognitiva e corporal, para a transformação da própria estrutura da obra. A obra só terá sentido, e estará concluída quando houver a participação física e sensorial do receptor.

O espectador, no exercício de sua sensorialidade, ativa a obra pelo movimento. Utiliza seu corpo como instrumento de dinamismo o que confere sentido e significação à arte. Nesse caso, é o receptor, o elemento agenciador da obra: interfere e modifica a configuração do objeto artístico.

Nesse jogo, as regras são propostas pelo artistas, mas cabe ao receptor a função de apreendê-las deixando fruir o "impulso gerador da forma como misto da razão e da sensação." E é por meio desse ato de elaboração da beleza estética que os significados da obra deixam-se construir. É a própria obra que incita o receptor à reflexão e sugerelhe novas descobertas (TAVARES, 2000, p.76).

A seguir serão apresentados trabalhos de artistas que se enquadram na Participação Mediada Corporalmente e que trabalharam a cor como forma de linguagem e expressão estética. Pelo fato de o uso da luz não se enquadrar neste segmento de participação, apresentaremos obras precursoras que propõem um novo sentido quando se experimenta a cor em sua potencialidade nos meios artesanais.Estreitam-se, assim, os vínculos com o espectador. 
Como já foi citado anteriormente, a arte cinética passou a se afirmar nos anos 50, apesar de no início do séc. XX já existirem artistas que experimentavam o movimento em suas obras. Os artistas cinéticos, segundo nos conta Dempsey (2003, p.198), nutriam grande interesse pela ciência e pela tecnologia. Suas obras faziam uso além do movimento, da luz e da eletricidade. Segundo a autora, a variedade da arte cinética foi também notável, das obras hipnóticas com movimentos lentos às esculturas cinéticas ao ar livre, que oscilam graciosamente, passando pelas obras cibernéticas e pelas esculturas telemagnéticas de objetos suspensos no ar. Interessa-nos neste item, aquelas obras em que, conforme Tavares (2000, p.74), a mediação se consolida com predominância na dependência da energia corporal e/ou ferramentas e instrumentos elementares, de base artesanal.

De acordo com Perissinotto (2000, p.5), artistas como Cruz-Diez, Yaacov Agam e Jésus Rafael Soto, além de solicitarem a participação do espectador para reconhecer o movimento aparente das obras, eles "propunham a sua transformação pela intervenção física do espectador, inaugurando assim uma interação transformativa”.

Nas obras selecionadas, é possível notar a intenção clara de tornar o espectador um participante ativo: pode alterar a estrutura da obra, testando a sua própria capacidade de percepção no contato com a cor.

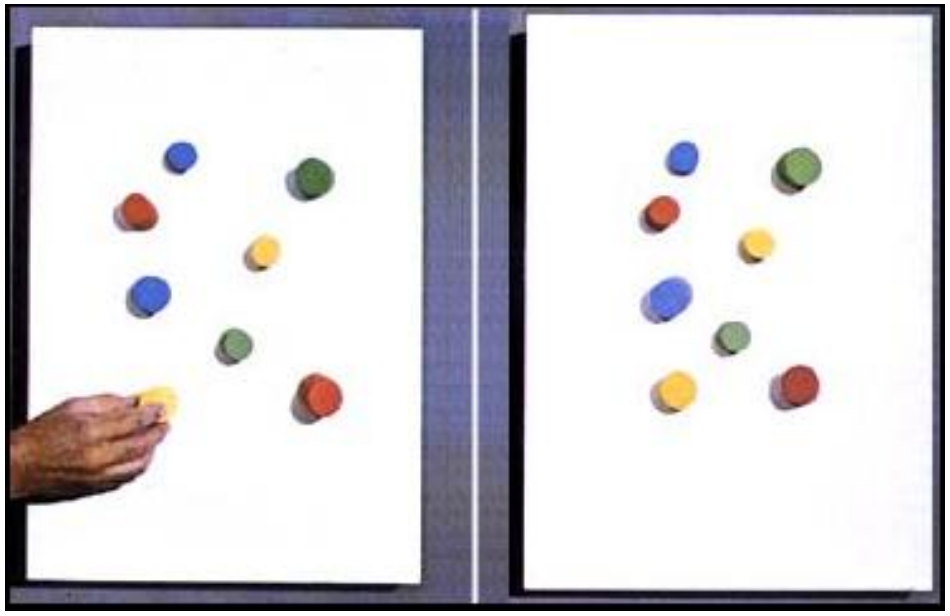

Figura 54: Muro de cilindros excéntricos manipulables. Caracas (1954), Cruz-Diez. Fonte: <www.cruz-diez.com> 


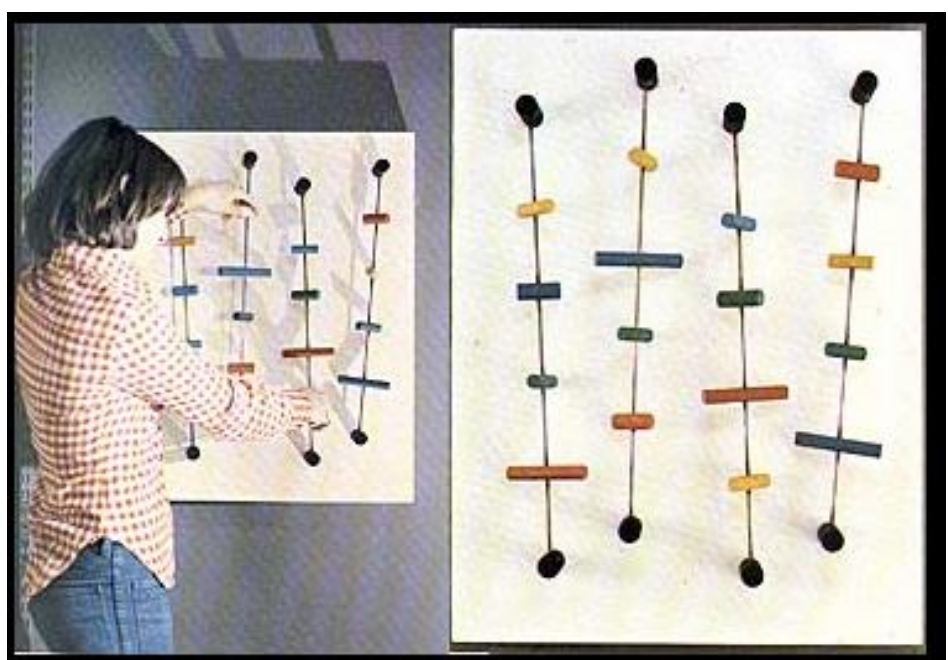

Figura 55: Proyecto para un muro exterior manipulable. Caracas (1954), Cruz-Diez. Fonte: <www.cruz-diez.com>

Uma espécie de pintura regulável, Transformables (1956), permitia que o espectador assumisse um papel ativo na recepção da obra. O participante então podia deslizar de um lado para outro, no espaço da tela, os elementos pictoriais da obra. O participante tinha então a liberdade de compor sua própria obra, da maneira que quisesse, mas de certo modo limitado, pelo conjunto dos elementos dispostos e propostos pelo autor. Em síntese o participante podia definir a disposição dos elementos a partir de suas cores e formas, utilizando para isso sua percepção e criatividade.

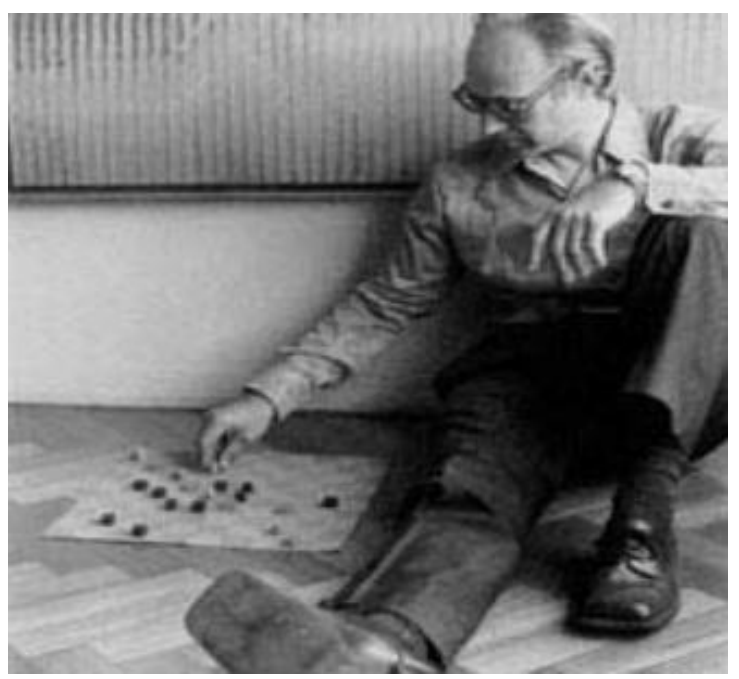

Figura 56: Jogo do Quadrado Perfeito (1971) Abraham Palatnik. Fonte: (PERISSINOTTO, 2000, p.31)

O Jogo do Quadrado Perfeito (1971) de Abraham Palatnik, apesar de não ter em seu foco principal a cor, permite, de maneira lúdica, a participação direta de dois receptores, garantindo que entre eles haja uma troca de informações que interferem na obtenção do objetivo proposto pelo jogo. Trata-se de um jogo de tabuleiro, em que o espectador/participante terá de apreender primeiro as regras ditadas pelo autor para 
poder participar. Nesse jogo, necessita-se da presença de dois jogadores; o ganhador é a aquele que conseguir formar um quadrado perfeito.

\section{Participação mediada automaticamente}

Este tipo de participação prevê, além do requisito mental e corporal, um acréscimo do movimento real da própria obra. Esse movimento ou ação da obra é obtido ou por fonte luminosa ou é gerado por origem mecânica.

Os meios intensificam e potencializam os gestos do receptor. Na participação mediada automaticamente, tende-se a "explorar os processos técnicos (de base industrial) como meio para propor e alcançar a tão desejada captura do receptor” (TAVARES, 2000, p.86).

A participação é, então, mediada corporalmente, e contruída por meio de dispositivos industriais-mecânicos que, "[são] utilizado[s] como princípio poético, perseguido[s] na intenção de solicitar a participação do receptor no contexto a ela inerente" (2000, p.86).

\footnotetext{
"Neste caso, os artefatos empregados na mediação entre obra e receptor imitam e amplificam a força muscular humana, pois incorporam mecanismos automáticos de variadas categorias, capazes de efetivar programaticamente específicas tarefas de geração do movimento, propostas em razão da conduta poética em vigor." (TAVARES, 2000, p.86-87)
}

Os artefatos ou dispositivos são utilizados como "potenciadores poéticos", ao mediarem a relação entre obra e receptor. Deste modo asseguram-se por meio da interface da obra os processos, segundo a autora, de tradução e interpretação dos códigos alográficos. Estes artefatos, de acordo com a autora, assumem desta forma o papel de incitar a troca entre obra e receptor através de procedimentos "reativos" e "auto-reguladores" (2000, p.87).

$\mathrm{Na}$ experiência idealizada pelo pólo criador, pretende-se descolar os mecanismos de suas reais funções, propondo-se a eles novos significados que não são usuais. Desta forma, nota-se uma aproximação e tentativa real de se trabalhar com o mecânico, um passo que possibilitou aos artistas ganhar fluência nesse campo e se deslocar para o instantâneo. 
As obras, que apresentaremos já configuram um uso automatizado da cor e da luz. São experimentações que trabalharam a informação luminosa e cromática de diferentes formas, antes impensáveis, o que gerou interpretações e percepções distintas do receptor.

Abraham Palatnik, artista naturalizado brasileiro, foi um dos pioneiros da arte cinética. Em seu Aparelho Cinecromático, tecidos sintéticos, motores, luzes e a incorporação do receptor são os elementos que estruturam a obra. Palatinik é um artista que se destaca pelo uso inovador da tecnologia.

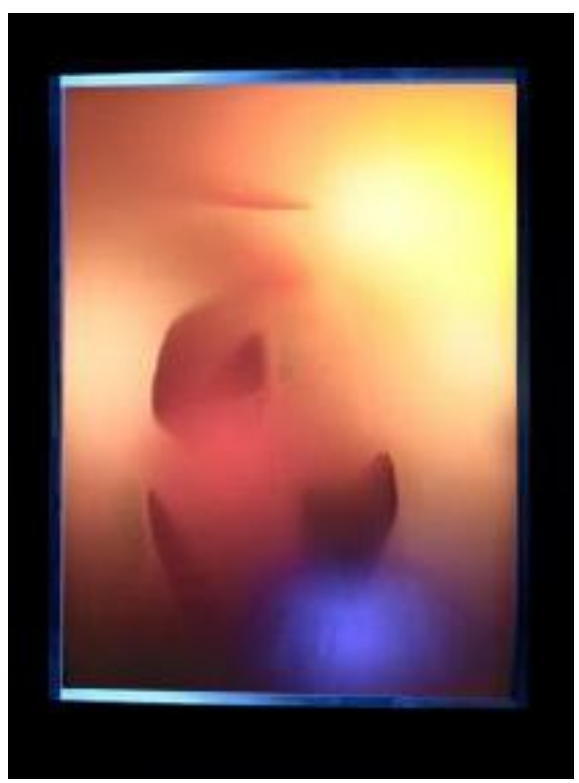

Figura 57: Aparelho Cinecromático (1958)

Abraham Palatnik.

Fonte: 〈www.nararoesler.com.br>
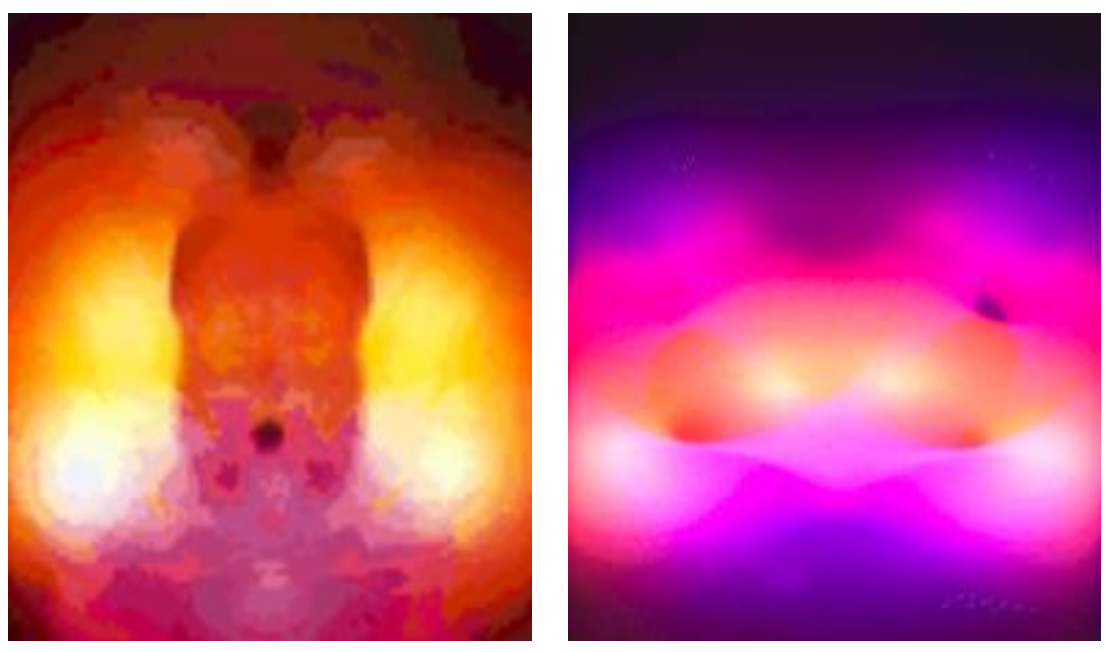

Figura 58: Aparelho Cinecromático (1955)

Abraham Palatnik.

Fonte:

(PERISSINOTTO, 2000, p.30) 
O aparelho cinecromático de Palatnik enfeitiça o observador quando se depara com ele. O movimento de cores e luzes e o ritmo luminoso preenchem todo o espaço da obra. As questões do artista são oriundas da pintura, mas transformadas pelo uso da tecnologia, e do motor, este que dá movimento a um circuito elétrico que acende um conjunto de luzes coloridas variadas. Esse mecanismo, escondido sob a tela, permite, exteriormente, a visualização do efeito da cor luminosa (OSÓRIO, 2004, p.60).

"A cor-luz pondo-se em movimento diferencia-se da corpigmento das pinturas e se expande no espaço incluindo o próprio espectador. É uma experiência de absorção e sedução que faz com que a tal 'abstração formal dinamizada' seja um lugar de sensibilização de formas e cores na intercessão entre a irradiação de luz e os olhos. Os cinecromáticos operam como fluxos de experiência formal continuada." (2000, p.61)

O receptor participava indiretamente. Quem movia a obra era o mecanismo elétrico que fora programado com o objetivo de capturar a atenção e o envolvimento sensível do espectador.

Nicolas Schöffer, desenvolveu suas primeiras esculturas espaço-dinâmicas funcionais, com motor elétrico na direção de torres cibernéticas dinâmico-luminosas em grande escala.

As proposições artísticas de Schöffer, ao preconizar a correlação da luz com o movimento, utilizavam projeções de luz colorida "como forma de desmaterialização da obra e de criação de novos espaços de percepção e mesmo de participação" (TAVARES, 2000, p.89). 


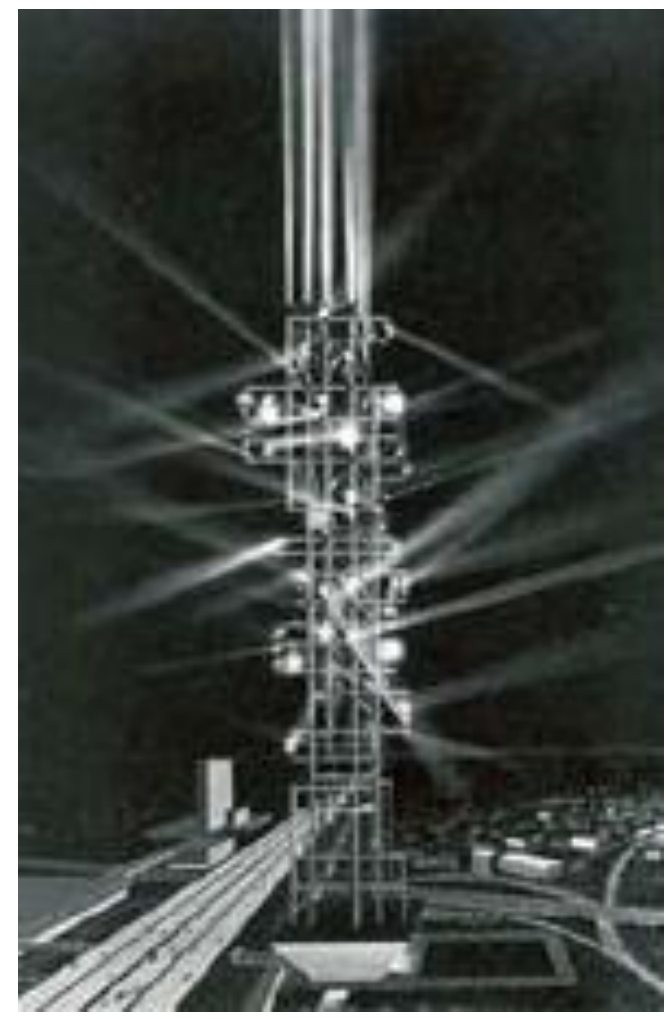

Figura 59:

Cybernetic Light Tower (1972)

Nicolas Schöffer.

Fonte: (POPPER, 1993, p.20)

Julio Le Parc, artista argentino e principal membro do grupo G.R.A.V.. Em suas obras, a idéia era desorientar o espectador e tirá-lo de sua condição apática.

Para Dempsey (2003, p.226), o G.R.A.V. (Groupe de Recherche d'Art Visuel - 19601968) se caracterizava pela exploração dos aspectos específicos da pintura e da escultura, assim como da "ilusão de óptica, o movimento e a luz". O interesse dos artistas desse grupo era o de engajar "o olho humano" e denunciar o elitismo pertencente à arte tradicional. Assim, envolvia-se o público no processo artístico. De acordo com a autora, o grupo buscava unir ciência e arte por meio da adoção de estratégias artísticas e métodos tecnológicos para a realização de obras dinâmicas e dialógicas.

A obra mais conhecida de Julio Le Parc é Móbile contínuo, luz contínua (1963), em que, de acordo com Dempsey (2003, p.226), “espelhos suspensos são soprados por ventiladores e acesos por luminárias móveis". Desta forma, o artista pôde explorar os efeitos do movimento, da reflexão da luz, ilusão e acaso na percepção do espectador. 

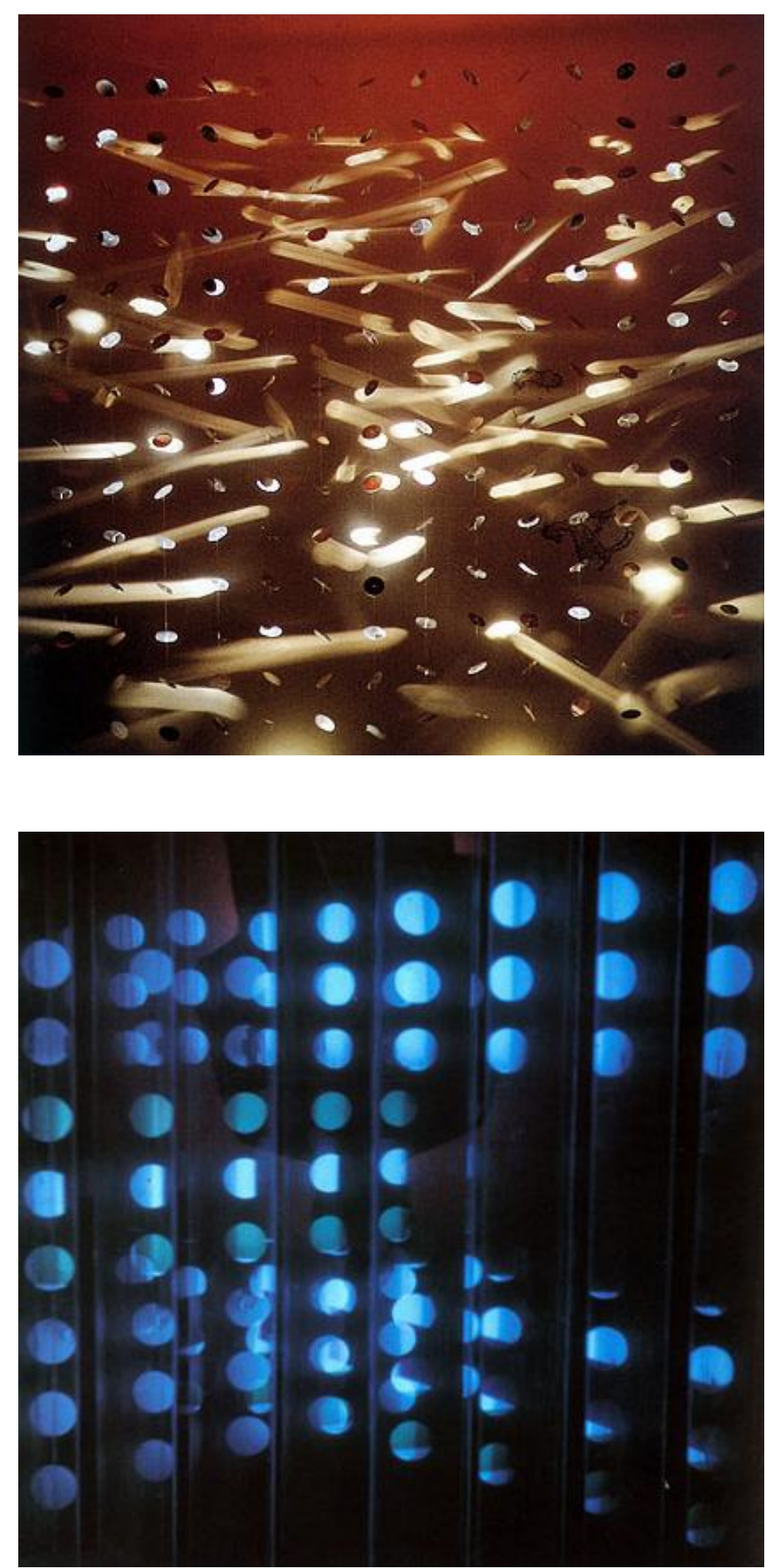

Figura 60: Móbile contínuo, luz contínua (1963)

Julio Le Parc.

Fonte: <www.julioleparc.org>
Figura 61: Continuel-couleurslumière (1965)

Julio Le Parc.

Fonte: <www.julioleparc.org>

A Participação Mediada Automaticamente caracteriza-se por pensar o "fato estético", conforme Tavares (2000, p.91), como um "evento em transformação, como uma obra em movimento.” A máquina seria a responsável por gerar o movimento que convida à participação. 
A intenção deste meio de participação é lançar algo novo, no "propósito de forjar os recursos da percepção para provocar diferentes modos de organização da sensibilidade, os quais, por sua vez, alteram as perspectivas e expectativas precedentes.” A presença deste novo ambiente criado afeta o receptor de maneira a renovar a sua "capacidade de interação entre sentidos" (TAVARES, 2000, p.91).

Paulatinamente, a participação do receptor se transforma da ação mediada corporalmente para a automaticamente, passando a recepção a comportar-se como um processo mais inclusivo do que exclusivo. Este passa, agora, de acordo com a mesma autora (2000, p.92), a “operar com base em códigos alográficos, já que o próprio meio dilui as marcas individuais da recepção". Em outras palavras, confere-se ao receptor a "potencialização da memória sinestésica".

\section{Participação mediada instantaneamente}

Nesse tipo de mediação, a participação assume um caráter interativo: pressupõe a intervenção ativa do receptor. A relação dialógica proposta pelo artista é um esforço de “engendrar trocas recíprocas entre obra e espectador, por meio dos recentes sistemas tecnológicos, que criam uma situação dentro da qual a obra reage (ou responde) às ações (ou questões) do receptor" (2000, p.93).

Diferente da participação mediada automaticamente, a mediação instantânea em vez de priorizar os meios eletro-mecânicos passa a utilizar máquinas mais sofisticadas que trabalham com sistemas numéricos. Para Tavares (p.93), estas máquinas são utilizadas "na intenção de assegurar a eficácia e a eficiência da mediação proposta pelo artista."

\footnotetext{
"É o aproveitamento cada vez mais frequente da eletricidade e consequente advento da tecnologia eletrônica que garante tal mudança. A instantaneidade e a velocidade atingem as formas de criação, e as funções de memória, automação e transporte são a elas incorporadas, garantindo a ação e a reação, quase que simultaneamente, em tempo real." (TAVARES, 2000, p.93)
}

Como refere a autora já mencionada (p.93-94), ao referir-se à Santaella, o processo de transformação da participação vai da automação motora para o da inteligência, passando pela automação sensória. Nesta transposição, alastra-se a possibilidade de unificação entre os sentidos, visto que é possível "programar uma espécie de jogo recíproco entre os mesmos". 
O computador passa a ser um meio que gerencia as trocas de informação e sentidos. Diferente das ferramentas técnicas, os dispositivos de base digital, nas considerações da mesma autora (p.94), permitem que a mensagem artística seja manifestada como fluxo de informação numérica, "podendo circular pelas interfaces para só depois vincular-se a quaisquer suportes, finalmente transcodificando-se e absorvendo especificidades dos meios a que está relacionada." A obra passa então, cada vez mais, a se desmaterializar devido às suas diferentes formas de manifestação. A obra permite, agora, a armazenagem de dados.

Foi, portanto, a partir da segunda metade do século $\mathrm{XX}$ - como vimos - que surgiu, na arte, o uso dos novos meios tecnológicos. Expandem-se os conceitos da cibernética e promovem-se avanços no campo da eletrônica e informática. De acordo com a autora, é a partir da década de 80 "que se dá o passo decisivo na direção da noção de participação mediada instantaneamente" (2000, p.95).

Atualmente, a cor como fonte luminosa artificial quase não enfrenta barreiras em sua manipulação física: pode ser trabalhada a partir de equipamentos e interfaces mais sofisticadas e sensoriais, o que permite um acesso e uma interação mais efetiva do receptor.

A seguir serão apresentados alguns artistas e obras que utilizam a mediação digital pelos meios eletrônicos em seus trabalhos. A ênfase será dada às obras que utilizam a cor e a luz numa relação cada vez mais próxima no intuito de inserir o receptor numa experiência sensorial e perceptiva.

O Clavilux 2000, desenvolvido pelos artistas Michael Götte e Veldana Sehic, de maneira instantânea associa imagem à música. A obra consiste em teclas de um piano digital ligadas a uma projeção vertical. Cada nota tocada no piano corresponde a um elemento visual que surge para cada nota tocada. Cada tecla está associada a uma cor, que cria um efeito sinestésico e suscita no receptor uma impressão harmônica, na relação com a música. A imagem que vai se formando à frente do receptor é constituída pelo conjunto de notas tocadas. Os sons permanecem e se sobrepõem uns sobre o outros até o final da música, o que permite uma imagem única, singular. 


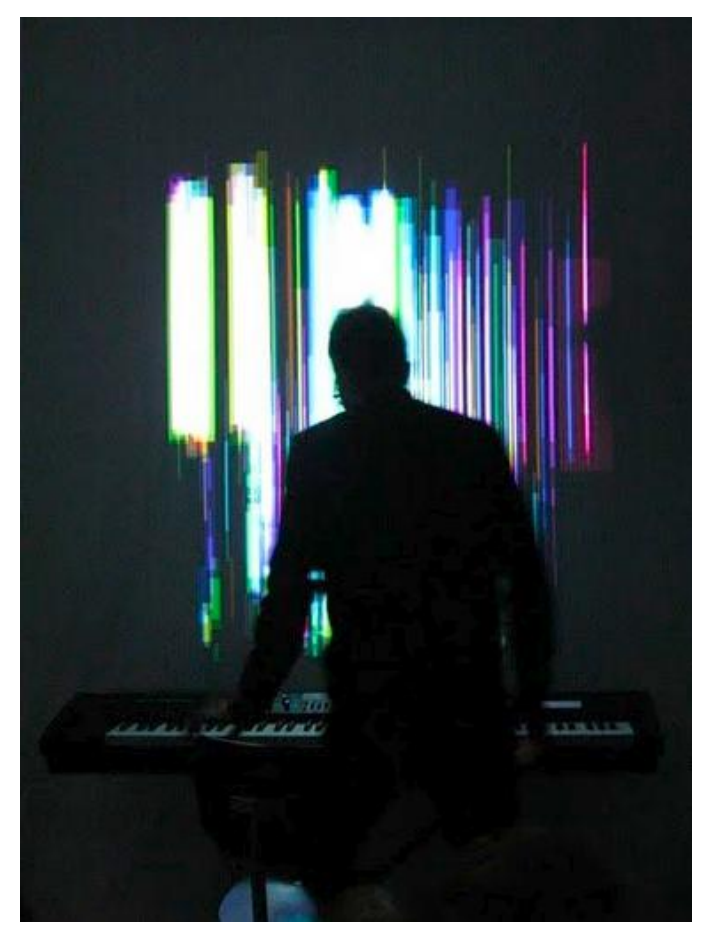

Figura 62: Clavilux 2000 (2009)

Michael Götte e Veldana Sehic.

Fonte: 〈www.jonasheuer.de>

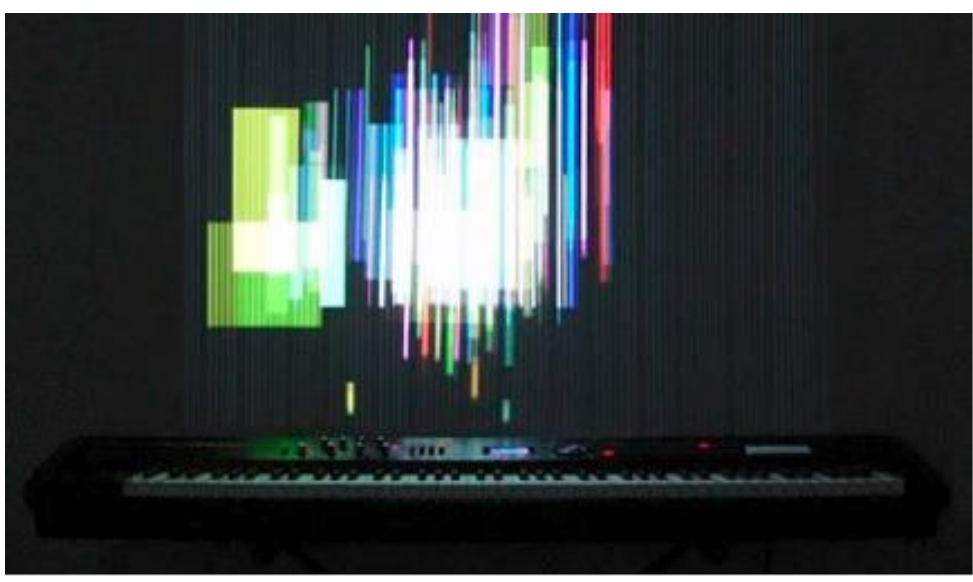

Figura 63: Clavilux 2000 (2009) Michael Götte e Veldana Sehic. Fonte: 〈www.jonasheuer.de>

O Clavilux 2000 consiste em 88 teclas de piano digital e de uma projeção vertical acima do instrumento, ambas integradas na linguagem de programação. A partir da música executada pelo participante, o programa converte os dados numéricos associados a cada tecla, em cores projetadas na superfície de projeção. Cada tecla corresponde a uma cor diferente, apresentada como tira vertical. O comprimento e a largura desta tira colorida vertical dependerão da pressão e tempo em que cada tecla for pressionada. A posição desta tira será correspondente ao posicionamento da tecla em relação à extensão do piano. 
Todas as tiras permanecem na tela projetadas até o fim da música, e de maneira aditiva elas se sobrepõem à medida que a mesma nota é tocada repetidas vezes. Forma-se, assim, uma composição única difícil de se reproduzir, uma vez que as informações se associam à pressão e ao tempo das notas musicais. O participante pode ainda optar por duas ou três dimensões na projeção das listras. A cor por fonte luminosa repercute no participante e no ouvinte como impressão harmônica e sinestésica.

Em outras palavras, a interação descrita caracteriza-se pelo acionamento das teclas do piano por meio de uma ação física, transmitindo para o programa numérico da obra dados referentes ao tempo e localização de cada tecla. Esses dados são convertidos pelo programa, em barras verticais, com cores e larguras correspondentes aos dados enviados pelo acionamento das teclas, elaborado pelo artista.

A obra Lightscoop, desenvolvida por Olga Mink e Roel Verlinden, permite que um participante, ao subir os degraus de uma escada, acione por meio de sensores infravermelhos (PIR) ${ }^{12}$ um painel de Plexiglas que se ilumina criando um rastro de cor à medida que sobe ou desce os degraus.

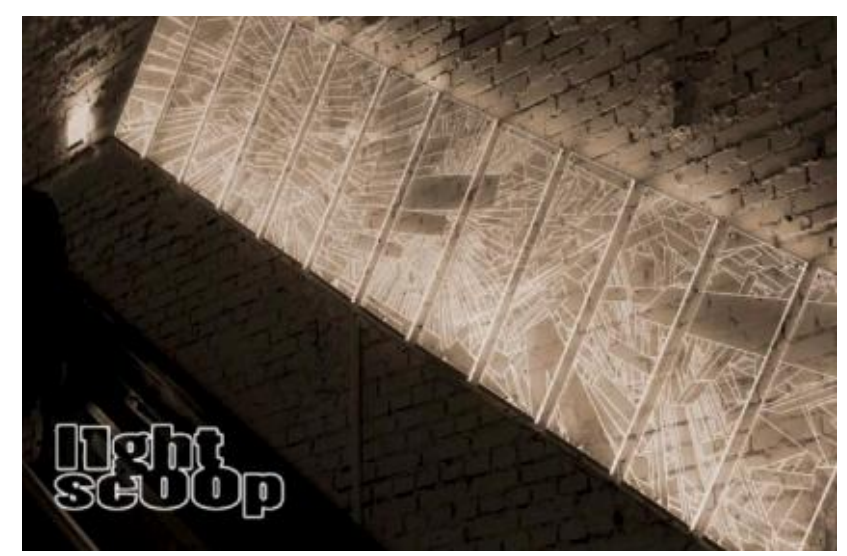

Figura 64: LightScoop (2008) Olga Mink e Roel Verlinden. Fonte: 〈www.videology.nu>

Cada degrau é interligado a um sensor infravermelho, que é responsável por acender um painel crivado por ranhuras desenhadas a laser, que são iluminadas a cada passo que o participante, registrando seu rastro, sobe ou desce as escadas. A cor produzida pelos LEDs ilumina os painéis em Plexiglas e são alteradas de forma randômica.

\footnotetext{
12 Informações adicionais sobre dispositivos tecnológicos que acionam ou emitem cor por fonte luminosa estão localizados no anexo deste trabalho.
} 


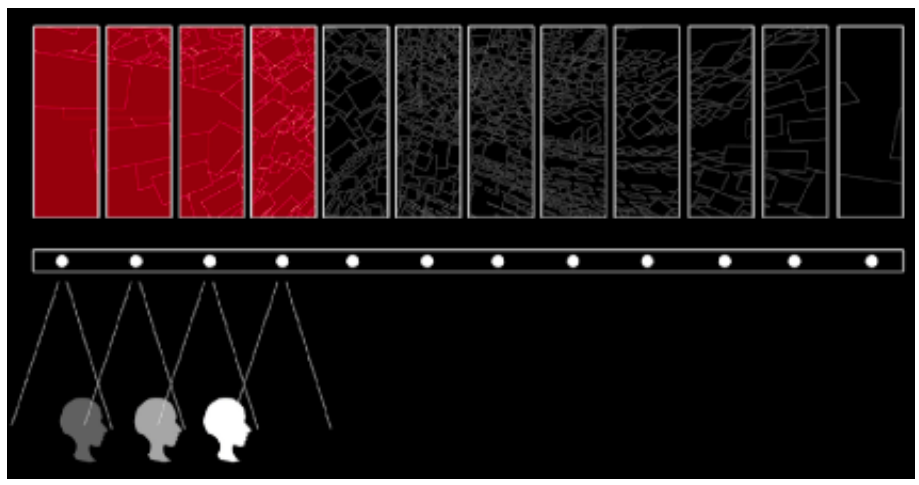

Figura 65: LightScoop (2008)

Olga Mink e Roel Verlinden.

Fonte: 〈www.videology.nu>

A interação nesta obra se baseia na detecção de movimento do participante transformada em cor emitida por LEDs. Quem sobe ou desce os degraus deixa exposto no painel de Plexiglas um rastro que marca sua presença e o contato com a obra.

A obra Optone, desenvolvida pelo designer japonês Tsutomu Mutoh, usa um objeto com um eixo vertical que, em seu topo, possui uma cúpula contendo LEDs que se iluminam a partir do movimento aplicado pelo participante. A estrutura da lâmpada sob a cúpula (mais leve), pode ser movimentada sem que sua base perca o contato com o solo devido a seu peso e à ação da gravidade. Desta forma, movimentos de rotação e balanço feitos por quem interage com o objeto são detectados por sensores, acionando os LEDs que estão dentro da cúpula. Ambos os dispositivos estão vinculados a um software, desenvolvido pelo autor, que associa uma cor às coordenadas pelas quais a cúpula passa.

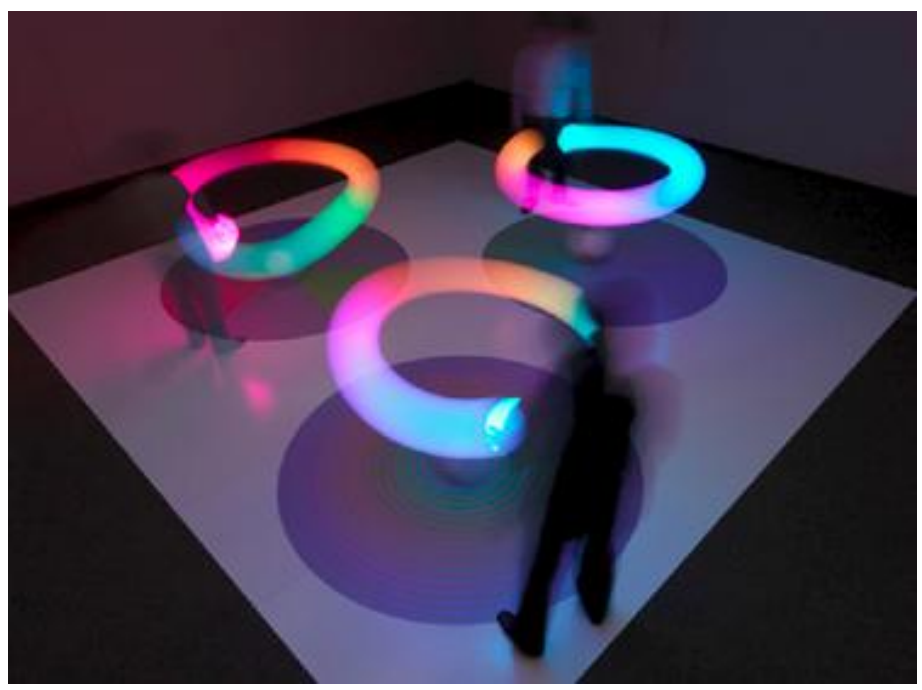

Figura 66: Optone (2009)

Tsutomu Mutoh.

Fonte: <mutoh.imrf.or.jp> 


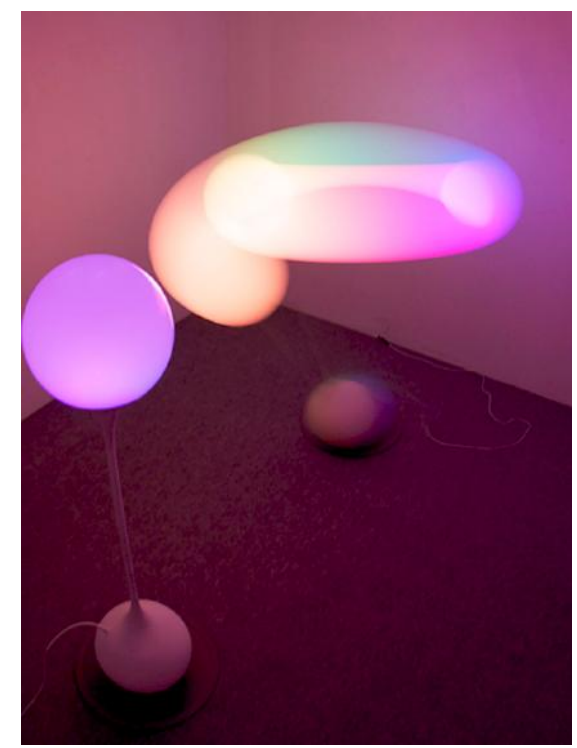

Figura 67: Optone (2009)

Tsutomu Mutoh.

Fonte: <mutoh.imrf.or.jp>

O receptor, ao manusear o Optone, perceberá o estímulo e a variação das cores por meio de alteração de valor, matiz, e croma. O algoritmo resultante aplicado nos LEDs vermelho, verde e azul acoplados às cúpulas do Optone torna possível o conforto visual e a interação com as cores em um espaço real.

A interação observada nesta obra se dá pelo acionamento físico transmitido em direção à lâmpada, fazendo-a mover-se em seu eixo de base central de maneira rotativa. $O$ participante, ao exercer essa força sobre o objeto, aciona por meio de sensores de movimento o software, que irá traduzir cada posição da cúpula em uma determinada cor (traduzida pela mistura aditiva dos LEDs vermelho, verde e azul). A rotação associada à lâmpada em seu próprio eixo gera um círculo de cores baseado no modelo Optone Color, desenvolvido pelo artista, que é transmitido pela lâmpada na ordem aleatória que o receptor a acionar.

A interação, no âmbito da Participação Mediada Instantaneamente, permite o acesso do receptor a um banco de dados numérico, que, conforme Tavares (2000, p.97-98), ao incorporar "as experiências das participações mediadas automaticamente e corporalmente", passa a eleger o computador como máquina gerenciadora da possibilidade de interação entre obra e receptor. 
A obra interativa se abre a "diferentes possibilidades de interação" que, de acordo com a autora (p.98), já estariam inclusas no programa previsto pelo pólo criador. As possibilidades de caminhos a serem explorados pela obra, apesar de estarem delimitados na configuração da obra, apresentam-se "potencialmente infinitos".

No âmbito da participação mediada instantaneamente, o uso da interação, potencializa, generaliza e multiplica as possibilidades de criação e recepção das obras participativas, intensificando o diálogo interativo entre receptor e e obra. A cor ao ser utilizada como linguagem pela obra produzida nas NTC possui um poder maior de potencializar o diálogo com o receptor. (2000, p.100)

\subsection{O reativo e o interativo}

No campo das Novas Tecnologias da Comunicação (NTC), é possível notar um número constante de obras que surgem utilizando o que há de mais recente nos meios numéricos. Estes recursos, que evoluíram das técnicas mecânicas, causaram uma diferença no modo de se tratar a relação entre o espectador e a obra, saindo da "participação" para a "interação". Estas obras interativas, de acordo com Machado (1997, p.144), possibilitam responder ao sistema de expressão e com ele dialogar. A interação então garantiria, para Tavares (2000, p.119-120), um contínuo diálogo entre o receptor e a máquina. Cada ação do receptor condicionaria uma re-ação da máquina com inversão constante dos papéis de receptor e emissor em um movimento circular.

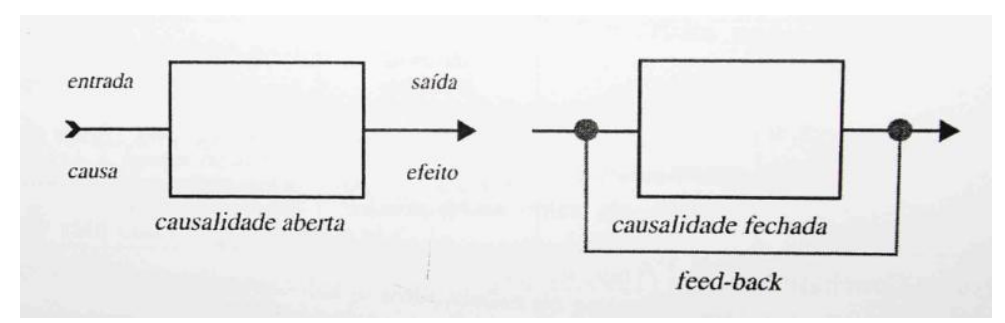

Figura 68: Tipos de causalidade, conforme a teoria cibernética. Fonte: (TAVARES, 2000, p.120)

Interatividade, uma característica das NTC, garante uma relação recíproca entre o receptor e o sistema assegurando, de acordo com Tavares (2000, p.111), a troca da informação, e garantindo a conversão de dados sob a forma numérica. Essa relação recíproca entre o receptor e o sistema gera a instantaneidade na intervenção da mensagem, o que permite, que se atualizem os "estados possíveis de sua matriz operacional". 
"Nas artes da interatividade, portanto, o destinatário potencial tornase co-autor e as obras tornam-se um campo aberto a múltiplas possibilidades e suscetível a desenvolvimentos imprevistos numa coprodução de sentidos". (PLAZA, 2003, p.20)

Percebe-se também nas artes interativas a tendência de os artistas tecnológicos, conforme Plaza (2003, p.17), se interessarem mais pelo processo de criação artística e de exploração estética do que pela produção de obras acabadas. Essa atitude demonstra o interesse de os artistas realizarem obras abertas, “onde a percepção, as dimensões temporais e espaciais representam um papel decisivo na maioria das produções da arte com tecnologia".

Até o momento tivemos acesso, no caminho a que esta pesquisa nos conduziu, a uma crescente e contínua atenção ao receptor/co-produtor, a quem cada vez mais se oferecem responsabilidades que o tornam imprescindível e indissociável da obra que se diz participativa, na tendência à interação. O papel do artista é o de promover uma "comunicação criadora" fundada nos princípios da "sinergia, colaboração construtiva, crítica e inovadora" (PLAZA, 2003, p.17).

O uso de interfaces técnicas, aliadas à noção de programa de base numérica, surge como alternativa para potencializar essa interação. Para Plaza (2003, p.17), a interação, a interatividade e a multisensorialidade se intersectam e se retroalimentam nas relações entre a arte e a tecnologia, dando base para a arte explorar dados "perceptuais, cognitivos e interativos". Para o mesmo autor (p.20), a inserção do programa como "agente ativo" e transformador entre o usuário e a máquina causa uma subversão nos esquemas tradicionais da comunicação. As categorias, antes ordenadas - emissor, receptor, mensagem e canal de comunicação -, entram em movimento e se entrelaçam.

Ao se falar de interface, não é mais suficiente ter algo físico ou material para ver e tocar. É necessário, conforme Poissant (2009, p.76), ter espectadores que possam vivenciar outras formas de sensação e talvez até outras formas de vida: podem se conectar de maneira diversa com o ambiente e com os outros.

No entanto, precisamos notar o fato de que tais ferramentas tecnológicas - que são introduzidas de maneira a intermediar o diálogo entre co-produtor e obra - nem sempre garantem plenamente a participação autônoma e verdadeira do espectador. O 
mecanismo atrelado ao ato de promover a interação pode oferecer ao receptor um domínio parcial sobre a obra. Foi pensando nisso que Frieling (2008, p.35) denominou novos termos e distinguiu a "interatividade" da "verdadeira interatividade". A "verdadeira interatividade" permitiria a abertura de condições locais que contribuam ativamente para a realização de um trabalho participativo. Por outro lado, a "interatividade" não permite que ocorra uma verdadeira interação, pois as opções dispostas ao receptor são pré-definidas. Cabe-lhe apenas selecionar uma ordem determinada no que já foi programado.

O conceito aplicado por Frieling, ao tentar definir os tipos de interatividade, é bastante próximo ao usado por Tavares, com base na cibernética, ao se referir à retroação negativa e positiva reproduzida por um sistema. Para Tavares (2000, p.122), é a ação mútua e simultânea entre o receptor e a obra que garante o funcionamento do sistema que pode reproduzir uma retroação negativa ou positiva. Para a autora, na retroação dita negativa, exalta-se um processo de "realimentação circular", caracterizado pelo feedback reativo que se instaura entre obra e receptor e que se manifesta por meio de "inputs, as opções de escolha já predeterminadas e sugeridas pela obra, que se encontram armazenados em memória". Neste caso, a obra permite ao receptor atualizar uma quantidade limitada de ações. Em contraste, está a retroação positiva, que, para a autora, permite que o receptor atue sobre a estrutura do banco de dados, propondo uma reorganização da obra a partir da articulação de suas variáveis. Neste caso, o receptor além de agir instantaneamente sobre o algorítmo, pode também recriar a obra a partir das regras estruturais já nele predefinidas gerando uma multiplicidade de novas artes.

As participações de ordem reativa, ou de retroação negativa, limitam o participante ao simples esquema de atualizar as opções poéticas propostas pelo artista. Neste tipo de participação, Poissant (2009, p.88) chega a afirmar que os artistas acabam "falhando", na tarefa de propor um espaço real para diálogo entre participante e obra. Seria como se a obra proposta nos fizesse, como participante, mover ao redor de um ponto dando-nos a sensação de que avançamos, sendo assim somos "iludidos" pelo que a obra aparenta oferecer. Dotado de um sistema auto-regulador, a retroação negativa, conforme Tavares (2000, p.125), induz o receptor a acreditar que as possibilidades não se esgotam. 
A "verdadeira interatividade" de Frieling, ou a retroação positiva, pressupõem que o participante atravesse estágios de implicações que vão desde a participação à interação efetiva, em que se viabiliza uma cooperação bidirecional de troca. Para Poissant (2009, p.88), os "alter-atores", como nomeia, são solicitados em experiências de interface, de modo que a obra dialógica se efetue. De acordo com a autora, o projeto iniciador deve criar e desenvolver um compartimento e um dispositivo pelo qual os visitantes se sentirão atraídos a participar, visto que descobrem e adicionam conteúdos e funcionalidade à obra. Esse tipo de participação prevê a ligação entre os participantes: cada um adentra na sensibilidade do outro, passando a considerar, nas palavras da autora, as "reações de um grupo no qual terão de modular sua própria intervenção".

Ainda no que se refere à retroação positiva, podemos associar esse comportamento sistêmico ao que Couchot, Tramus e Bret (2003, p.27-28) nomeiam como a segunda interatividade, que encontra relação com os novos campos de experiência no domínio técnico-científico, da comunicação e da arte. Essa interatividade de caráter endógeno se refere a atividades maquínicas mais complexas e refinadas do que o usual, que simula comportamentos. Percebe-se que nesta fase ou patamar de interação, o computador é pouco a pouco "dotado de propriedades que são em geral características dos seres vivos inteligentes".

Já na interatividade exógena, proposta por Couchot, Tramus e Bret (2003, p.32), estabelecida em analogia à retroação negativa, a relação entre o computador e o homem segue o modelo "estímulo-resposta" ou "ação-reação", sem, no entanto, envolver ações mais inteligentes e autônomas geradas pela máquina. Vale lembrar que esses dois tipos de interatividade - exógena e endógena -, não são excludentes entre si.

“[...] pode-se admitir que, a depender da poética que uma dada obra expõe, implicada pelas propostas de interação viabilizadas a partir das interfaces utilizadas (hardware e software), o receptor pode vir a agir de duas maneiras (não excludentes) sobre o banco de dados numéricos. Estes dois modos de ação corresponderiam, em analogia com a cibernética, às retroações auto-reguladora e autoamplificadora. Seja ao reproduzir a retroação negativa ou a retroação positiva, o que mantém o sistema em funcionamento é a ação mútua e simultânea entre receptor e obra." (TAVARES, 2000, p.122) 
Todas as classificações citadas visam identificar o processo pelo qual a arte tecnológica atravessa no sentido de tornar a interação com o espectador mais dinâmica. Os dispositivos mais recentes tendem a potencializar, ainda mais, a percepção do receptor no sentido de apreender sensivelmente a poética proposta pelo artista.

De acordo com Poissant (2009, p.89), as artes da comunicação privilegiam a multiplicação de canais de recepção pela interseção das mídias, o que promove uma relação e troca dentre os próprios participantes de modo a trabalhar a obra, e senti-la mais que pensá-la. Para a autora, o corpo é palco de múltiplas trocas, com dispositivos de regulagem e renovação. Neste sentido, o desenvolvimento das interfaces de mídia tem contribuído para tornar visíveis certas funções corpóreas, unindo nossas representações ao nosso modo de ver.

No próximo capítulo abordaremos obras interativas, que classificadas por possuir uma mediação de ordem instantânea fizeram uso da cor proveniente de fonte luminosa como abertura poética capaz de atingir o receptor / interator. As obras selecionadas no capítulo quatro não utilizarão a retroação positiva das tecnologias inteligentes, no entanto, servirão como base para analisar diferentes modos de inserir o receptor na obra, com ênfase para os dispositivos ligados à incorporação da cor luminosa. 
"A corpode exprimir uma atmosfera, descrever uma realidade ou codificar uma informação."

Ellen Lupton e Cole Phillips 


\section{Capítulo 4}

\section{Sobre as leituras de obras}

Este capítulo será dedicado à leitura de obras, parte fundamental e determinante da pesquisa, uma vez que, com base nas informações provindas dos capítulos precedentes, obtém-se repertório para apreender nas obras: o percurso poético proposto pelos artistas e a forma como a cor proveniente de fonte luminosa foi tratada de modo a inserir o receptor. Por meio de uma abordagem experimental, a leitura do objeto de pesquisa se propõe a identificar nas obras a fundamentação dos estudos cromáticos e de luz aplicados nos dispositivos de participação das Novas Tecnologias da Comunicação (NTC) e as correlações com o tipo de abertura no que se refere à participação do espectador.

Essa leitura procura demonstrar como a cor proveniente de fonte luminosa foi manipulada pelo artista a fim de se potencializar uma informação como um agente do meio de comunicação e dessa forma atingir a atenção do receptor, introduzindo-o na obra como elemento fundamental para trazer a ela sentido e função. Assim, dados teóricos sobre a fundamentação histórica, os aspectos físicos, fisiológicos, psicológicos e culturais da cor, e os conceitos de obra aberta e participação, até então investigados nesta pesquisa, darão aporte científico para uma abordagem ampla dos exames. Sempre que necessário, recorrerei a esses dados correlacionando-os à leitura de modo a melhor interpretar cada obra e alcançar os objetivos por essa pesquisa propostos.

As obras selecionadas foram produzidas com base no uso das NTC e, como forma de expressão em comum, se valem do uso da cor proveniente de fonte luminosa. Todas elas são obras abertas cuja participação é mediada instantaneamente. A interação destas obras se dá de maneira exógena permitindo uma circularidade no diálogo entre o receptor e a obra. A poética construída pelo artista visa o retorno e a participação do receptor, para que a obra adquira um sentido. Muitas vezes esse processo criativo percorrido pelo artista não é perceptível à primeira vista, sendo necessária uma leitura investigativa que auxilie na desconstrução dessa obra, para se apreender sua poética. 
No caso das obras abertas que utilizam a cor como fonte luminosa, o processo de produção está invariavelmente ligado ao uso das tecnologias, não sendo possível dissociá-las daquela. Esse modo de operar revela a transição do uso da cor do objeto para a cor de fonte luminosa nas obras digitais. No recorte proposto por esta pesquisa, $\mathrm{o}$ artista define a cor como elemento mediador do processo, utilizando-a como um elo na comunicação entre a obra e o receptor. $\mathrm{O}$ perfil de obra definido por esta pesquisa considerou, portanto, que a cor, como elemento mediador, seria materializada por meio de dispositivos tecnológicos ${ }^{1}$ que, ao emitirem diferentes frequências de luz, possibilitam ao artista trabalhar com uma gama variada de cores.

Foram então selecionadas três obras que, produzidas com base nas NTC, visam exemplificar o uso da cor como fonte luminosa sob três diferentes formas de participação. Poderíamos categorizar esses níveis de participação pela estratégia de interação proposta pelo artista. A primeira e a última obra se caracterizam pela ação do clique, seja pelo uso do celular, ou pelo uso do computador, e a segunda, pelo próprio movimento do receptor, pela sua presença física e corporal. No que se refere à forma de expressão e materialização da cor através de fonte luminosa, elegemos duas categorias. A primeira e a última obra se referem ao uso da cor emitida por fonte luminosa e a segunda obra faz uso da cor projetada por fonte luminosa.

Nas leituras, buscou-se, através do estudo dos mecanismos de expressão e articulação da obra com o receptor, identificar como a cor derivada de fonte luminosa foi utilizada como potencial expressivo. No fim buscou-se, por meio de um exame da expressividade manifestada na atualização da obra pelo receptor, destacar em cada uma das leituras as seguintes dialéticas a ela inerentes: aleatório e controlado, individual e coletivo, projetado e emitido, informação estética e semântica, material e (i)material.

\footnotetext{
${ }^{1}$ Em anexo neste trabalho encontra-se de maneira detalhada um número variado de dispositivos tecnológicos cuja função é a emissão de luz.
} 
É importante esclarecer que o conteúdo de cada leitura dependeu da informação contida na própria obra e também nas respostas dos artistas ao questionário realizado (dispostos nos anexos) e nos textos publicados sobre as obras. Desta forma, algumas leituras podem parecer mais ricas em detalhes se comparadas com outras. Também não se procurou estabelecer verdades únicas no que se apreendeu nas obras, pois não se pode ser unilateral na decodificação de uma obra aberta que é caracterizada por possuir uma rede de significações. As leituras aqui propostas procuraram abrir caminhos contextualizando a polissemia da obra que por natureza se abre a diversas significações.

Como instrumento para ajudar na leitura e apreensão da poética, foram elaboradas questões $^{2}$ do tipo roteiro. Estas questões, que, por vezes, a depender do artista se tornaram uma espécie de diálogo, foram apresentadas a cada um dos autores das obras selecionadas e por eles respondidas. Essas questões foram divididas em tópicos e apresentadas a cada um dos autores contribuindo para um maior aprofundamento nas abordagens levantadas durante a leitura.

A leitura das obras e as possíveis comparações entre elas serão expostas na conclusão de modo a apreender o processo criativo envolvendo o uso da cor como fonte luminosa visando a participação em uma obra.

\subsection{Justificativas para a escolha do perfil das obras}

\subsubsection{Características em comum utilizadas na seleção das obras:}

- Todas as obras selecionadas foram realizadas ao ar livre, fora do ambiente de galerias e museus e no período noturno;

- Interação em massa, contato social e urbano;

- São obras oriundas das NTC, cujo sentido depende da interação do receptor de modo a desencadear um diálogo circular e de realimentação entre interator e obra;

- Por serem obras tecnológicas são expressas pela luz, seja ela projetada ou emitida;

- Possuem a cor proveniente de fonte tecnológica como elemento poético de expressão;

\footnotetext{
${ }^{2}$ As questões e diálogos trocados com cada um dos três artistas responsáveis pelas obras lidas estão presentes em formato de anexo ao final deste trabalho.
} 


\subsubsection{Justificativa do porquê dessas características e sua relevância em relação ao tema central da dissertação}

Todas as obras selecionadas foram realizadas ao ar livre, fora do ambiente de galerias e museus e no período noturno;

De acordo com Poissant (2009, p.76-77), uma das alternativas para envolver o espectador cada vez mais no processo de criação seria a de levar a obra para fora dos espaços fechados como a galeria, por exemplo. No meio externo não existe o silêncio, não existem atitudes pre-concebidas, não existe a intenção. A obra sai do museu e da galeria para ficar próxima do público geral. Desta forma, levando-se em conta que o recorte desta pesquisa se dá no uso da cor por fonte luminosa, entendemos que para viabilizar a percepção da obra, esta deve ser atualizada durante o período da noite, quando há pouca ou nenhuma luminosidade. Desta forma, a intensidade das cores é maior e mais perceptível devido ao contraste com a escuridão. A luz colorida quando utilizada em locais externos de pouca ou quase nula iluminação natural impressiona e chama a atenção de um observador passante. O contraste da cor como informação luminosa em face da escuridão da noite estabelece comunicação com o observador seduzindo-o pelos sentidos que tal cor suscita.

\section{Interação em massa, contato social e urbano;}

Como pudemos perceber até aqui, a produção de relações, causada quando pessoas interagem para apreender a poética da obra, é uma característica marcante das NTC. Como será visto nas obras selecionadas, os dispositivos tecnológicos provenientes do desenvolvimento da ciência e da tecnologia viabilizaram novas maneiras de propiciar essa interligação entre os participantes. Estes participantes trocam experiências e percepções formando, conforme Prado (1997, p.298), um “fluxo de sensibilidades” em um espaço partilhado ${ }^{3}$.

\footnotetext{
${ }^{3}$ No caso das obras a seguir examinadas, este conceito se aplicará parcialmente uma vez que elas se diferem em graus de participação. Na primeira obra a participação será individual porém dirigida ao público de uma cidade. A segunda obra poderá ocorrer tanto individualmente quanto coletivamente e a terceira só terá sentido com a participação do coletivo.
} 
São obras, oriundas das NTC, cujo sentido depende da interação do receptor de modo a desencadear um diálogo circular e de realimentação entre interator e obra;

As obras pertencentes às Novas Tecnologias da Comunicação se classificam em reativas ou interativas e nesse caso se delimita um tipo de participação instantânea por parte do espectador. Neste cenário o interesse recai no receptor, que "descobre" a obra em um processo de diálogo e troca informacional com a máquina. No caso das obras aqui listadas, a participação se dá de maneira reativa. A obra, portanto, só faz sentido com a participação e diálogo do público. Na era das redes telemáticas, de acordo com Prado (1997, p.297), o artista "inventa novos agrupamentos, coleta os elementos, junta, separa, justapõe, tenta dar uma nova ordem, coloca a luz sobre certos pontos, propõe novos jogos, cria metarregras, guiado por um objetivo: o trabalho artístico." Este "intercâmbio dinâmico", segundo o autor, constitui uma interface entre "homens e imaginários", dando ao artista o papel de "poeta da conexão", sendo cada participante um "coprodutor", gerando novas situações e uma potencialização de atuações.

\section{Por serem obras tecnológicas são expressas pela luz, seja ela projetada ou emitida;}

Sem luz não há cor, seja ela de fonte luminosa ou proveniente de objeto. No contexto desta dissertação que volta a sua atenção para o uso da cor de fonte luminosa, entendese que essa cor, nas NTC, é obtida artificialmente e não naturalmente, como seria o caso da vela ou da luz solar. Desta forma, é necessário pensarmos na eletricidade como base para se utilizar a luz, projetada ou emitida, a partir de uma fonte. O advento da eletricidade promoveu a posssibilidade de artistas poderem manipular a luz na produção de suas obras. Desde a época em que a arte cinética começou seus primeiros experimentos com o uso da luz até os dias atuais houve uma mudança drástica na forma de se operar a luz, acrescentando a essa nova realidade o desenvolvimento de novos aparatos e tecnologias que contribuem para a aparente imaterialidade destas fontes.

\footnotetext{
4 A noção de (co)produtor se aplica de acordo com o autor a um espaço partilhado de troca de experiências. Nas obras a seguir examinadas este conceito se aplicará parcialmente uma vez que elas se diferem em graus de participacipação, como descrito na nota anterior de maneira detalhada.
} 
Possuem a cor proveniente de fonte tecnológica como elemento poético de expressão;

O uso das cores através de fontes luminosas é uma característica das instalações interativas das NTC. Sua natureza quase que imaterial desperta no espectador uma variedade de sentidos e percepções. Esse sentido que atribuimos às cores que vemos em nosso dia-a-dia são exclusivos de cada indivíduo e, como vimos anteriormente, podem variar de cultura para cultura. O artista que opta por trabalhar nos meios digitais pretende estreitar a distância entre a poética proposta e o participante e no caso das obras aqui expostas se utiliza da cor como esse elemento intermediador cujo papel é o de cativar o espectador. A linguagem simples e clara da cor como elemento informacional, dentro de uma comunidade, permite ampliar a abrangência e o alcance desta obra, tornando possível e facilitando o diálogo com o receptor que supostamente não encontraria dificuldades durante este processo dialógico. 


\subsection{Apresentação das obras e justificativas}

\section{Obra \# 01: Colour by Numbers}

Artista: Erik Krikortz

Designer Interativo: Loove Broms

Arquiteto: Milo Lavén

Início da instalação: 23 de outubro de 2006

Término da instalação: 01 de abril de 2007

Localização: Stockholm - Suécia

Fonte: Colour by Numbers. Website oficial da obra: <www.colourbynumbers.org>. O artigo Claiming Space de Charlotte Bydler. As demais informações são referentes ao questionário apresentado ao artista (disposto nos anexos).

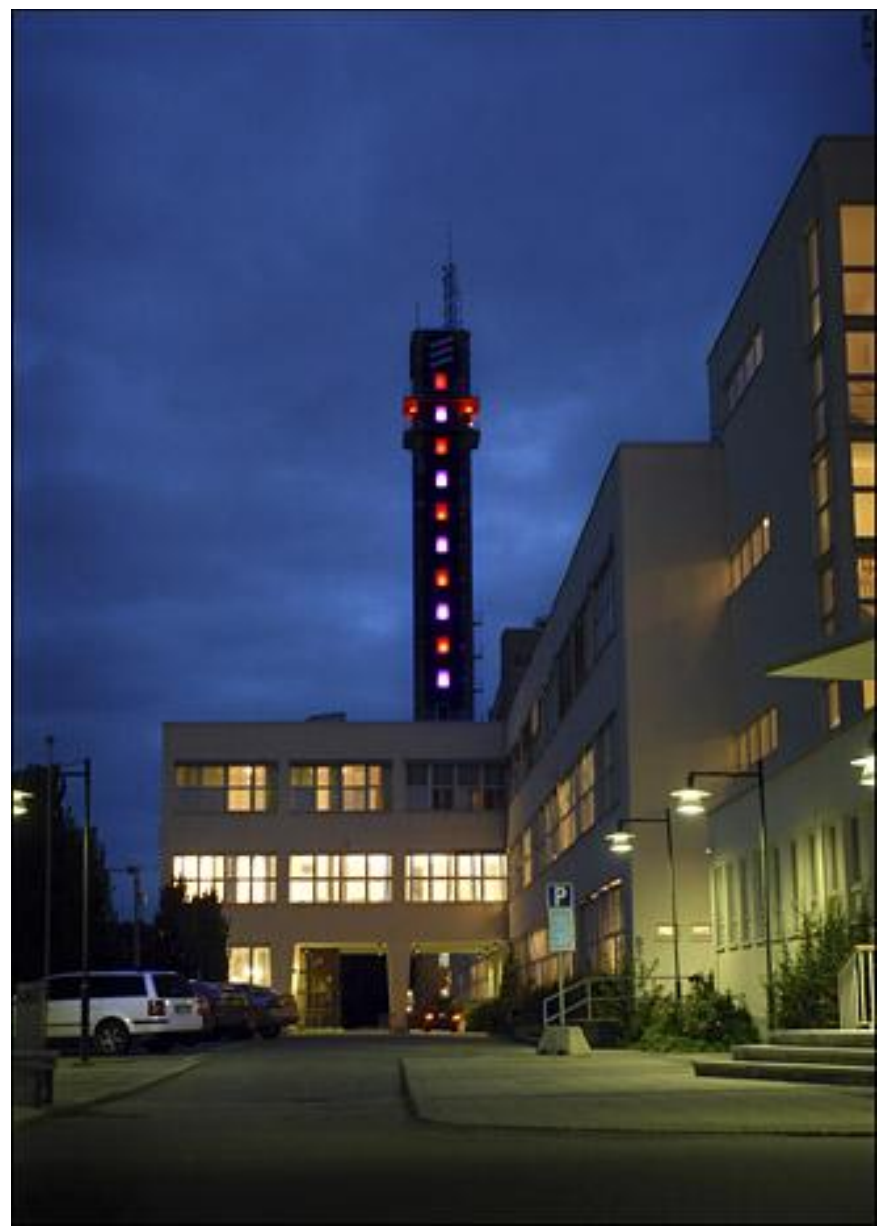

Figura 69: Vista do edifício Telefonplan. Fonte: 〈www.colourbynumbers.org> 


\section{Justificativa e conformidade com o tema central da pesquisa}

- A obra é exibida no ambiente externo e durante um período do ano em que se tem baixa luminosidade

- Cada interator possui individualmente o domínio sobre a cor, determinando a mistura óptica aditiva através do acesso a um aparelho telefônico de rede móvel ou pela Internet. A participação é individual porém destinada ao coletivo da cidade;

- Trata-se de uma instalação na qual a participação se dá de maneira reativa;

- A cor é na instalação emitida a partir de fonte luminosa (LEDs);

- O participante se expressa pela cor, que ele tem o poder de definir, transmitindo por meio dela uma mensagem a ser exibida para a cidade.

\footnotetext{
5 A obra aconteceu durante o período de inverno da Suécia que usualmente se caracteriza pela baixa luminosidade durante a maior parte do dia.
} 


\section{Obra \# 02: Forest of Light}

Artistas: Christina Mejborn / Line Langballe

Data da instalação: setembro de 2009

Localização: Copenhague - Dinamarca

Fonte: Totem Collective. Website oficial da obra: <www.totemcollective.com>. As demais informações são referentes aos diálogos mantidos com as autoras (disposto nos anexos).

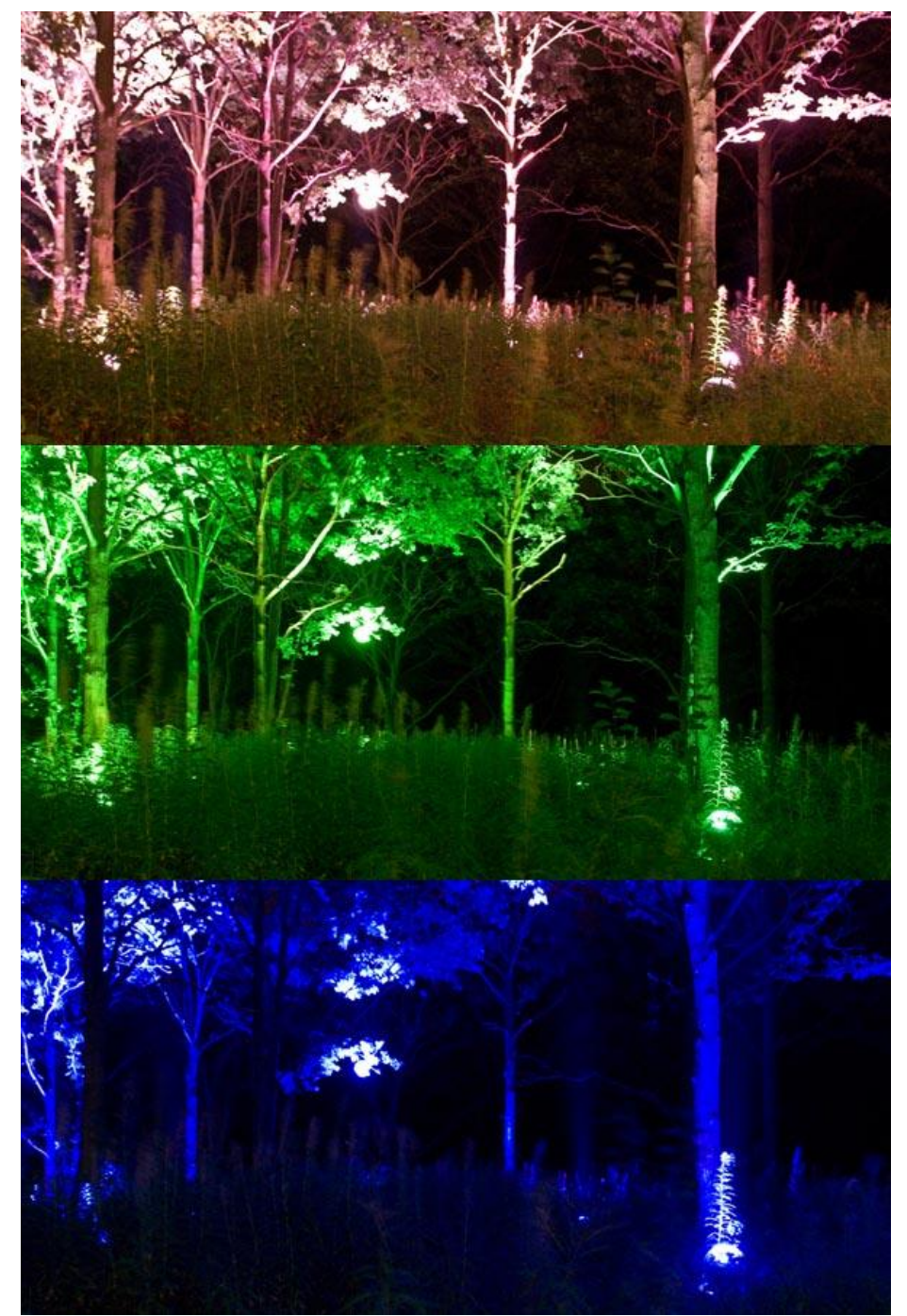

Figura 70: Forest of Light - projeção em vermelho, azul e verde.

Fonte: <www.totemcollective.com> 


\section{Justificativa e conformidade com o tema central da pesquisa}

- A obra é exibida no ambiente externo e no período noturno;

- Cada receptor possui individualmente o domínio sobre a cor projetada, em conjunto com outros participantes; ela alcança uma extensão grande de projeção e com uma multiplicidade de variantes cromáticos;

- Trata-se de uma instalação na qual a participação se dá de maneira reativa;

- A cor se encontra na instalação e é projetada a partir de fonte luminosa (LEDs);

- $\mathrm{O}(\mathrm{s})$ receptor(es), para dialogar com a obra, precisa(m) subir em troncos de madeira para que dessa forma possa(m) perceber uma variação nas cores projetadas e assim explorar as diversas formas de se "colorir" a floresta; 


\section{Obra \# 03: D-Tower}

Artista: Q.S Serafijn

Arquiteto: Lars Spuybroek

Início do projeto: 1998

Início da construção: 2003

Localização: Doetinchem - Holanda

Fonte: As informações textuais e de imagens da obra foram pesquisadas no endereço oficial da obra <www.d-toren.nl>, no endereço oficial do escritório de arquitetura que executou a obra <www.nox-art-architecture.com>, no livro Art \& D: research and development in art (2005), onde um capítulo escrito pelo artista Q.S. Serafijn explica detalhadamente o projeto D-Tower e no livro NOX: machining architecture (2004). As demais informações são referentes ao questionário apresentado ao artista (disposto nos anexos).

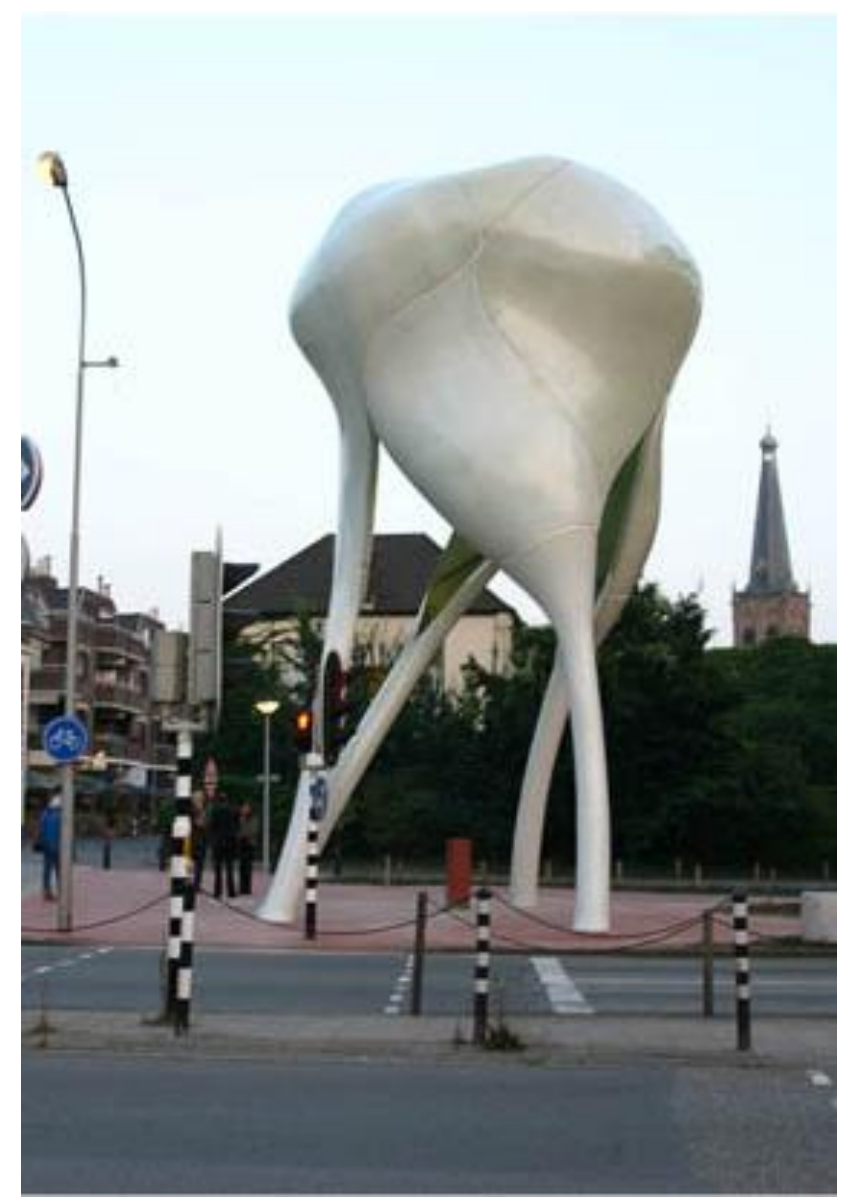

Figura 71: D-Tower.

Fonte: <www.nox-art-architecture.com> 


\section{Justificativa e conformidade com o tema central da pesquisa}

- A torre está situada ao ar livre e entra em funcionamento, emitindo as cores, apenas no período noturno;

- Para que a obra tenha sentido é necessária a participação de mais de uma pessoa, sendo necessário que sejam habitantes da cidade onde a torre está instalada;

- A obra permite ao participante uma interação reativa, contudo, permite a possibilidade de representar as emoções da coletividade participante, numa analogia à idéia de "coautoria";

- A cor se encontra na instalação e é emitida a partir de fonte luminosa (LEDs);

- A cor nesta obra é vinculada a quatro sentimentos básicos. 


\subsection{Contextualização e leitura}

\subsubsection{Colour by Numbers ${ }^{6}$}

A obra Colour by Numbers foi desenvolvida em parceria pelo artista Erik Krikortz, o designer interativo Loove Broms e o arquiteto Milo Lavén e foi executada até hoje duas vezes $^{7}$. Essa instalação já foi apresentada em Estocolmo, na Suécia, no prédio da Telefonplan (2006-2007), e na Torre de Perdigones (2008), em Sevilha, na Espanha, no contexto da Bienal Internacional de Arte Contemporânea de Sevilha.

Quando exposta em Estocolmo, o edifício escolhido pelos autores foi a Telefonplan, anterior base da L. M. Ericsson reservada para abrigar experiências com a tecnologia de microondas. A torre, de 72 metros de altura, se destaca em meio à cidade pela sua imponência e envergadura. Devido a sua posição privilegiada, favorecia a poética proposta pelos autores de agir como uma plataforma de comunicação, uma vez que qualquer habitante da cidade, por meio de um celular ou pela internet, podia alterar a sequência de cores nas janelas, escrevendo a sua própria mensagem fundamentada no uso da cor como fonte luminosa. Essa comunicação se configurou como um farol à disstância para assinalar a presença da cidade.

Para tornar possível o papel comunicador da torre foi necessário adequar sua estrutura e pensar em um mecanismo que contribuísse para esse propósito. A torre então foi equipada, em cada um de seus dez últimos andares, com potentes LEDs que, posicionados por trás das janelas, seriam capazes de ser identificados à distância no período noturno. Quem identificaria e se responsabilizaria por essas luzes seria o próprio público passante, os pedestres da cidade, que assistiriam a essa comunicação. Assim, uma das maneiras de se acionar as luzes da torre seria através dos celulares, item comum a praticamente todos os habitantes daquele país. A outra maneira de se alterar as cores da torre seria pelo website da obra. Nele as pessoas que quisessem participar, mesmo estando longe do local, poderiam interagir com as cores luminosas e veriam o resultado através de uma webcam instalada próxima a torre ${ }^{8}$. Um banco de dados seria o

\footnotetext{
${ }^{6}$ Disponível em: <www.colourbynumbers.org>. Último acesso em: 24/08/10.

7 De acordo com os autores esta instalação se tornará permanente em todos os invernos a partir do ano de 2010, em Estocolmo na Suécia.

${ }^{8}$ Nesta leitura daremos ênfase à comunicação pelo celular por não termos informações suficientes sobre o mecanismo para se alterarem as cores por meio do site.
} 
responsável pela tradução da informação advinda de ambas as formas de participação, traduzindo essa informação em um comando que acionaria as luzes por trás de cada janela do edifício.

Para interagir com a obra, os participantes deveriam seguir algumas instruções. A estratégia de interação proposta pelos criadores previa que, por meio dos toques no teclado do celular ou do computador, o usuário acionaria códigos que, traduzidos pelo computador central, seriam transformados em informação cromática e espacial, estabelecendo para cada andar uma cor específica, conforme o comando do participante.

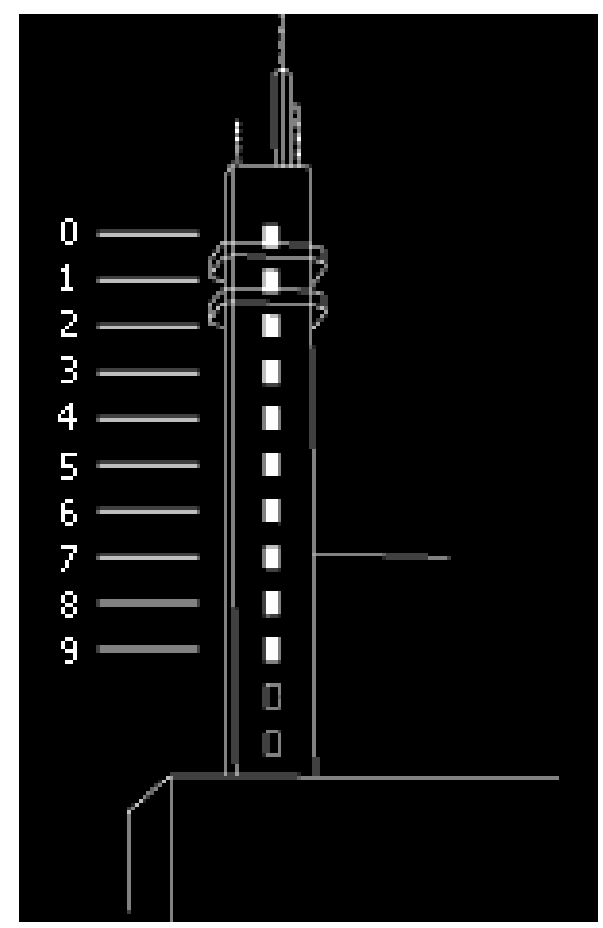

Figura 72: Gráfico com a numeração atribuída aos andares do edifício Telefonplan. Fonte: 〈www.colourbynumbers.org>

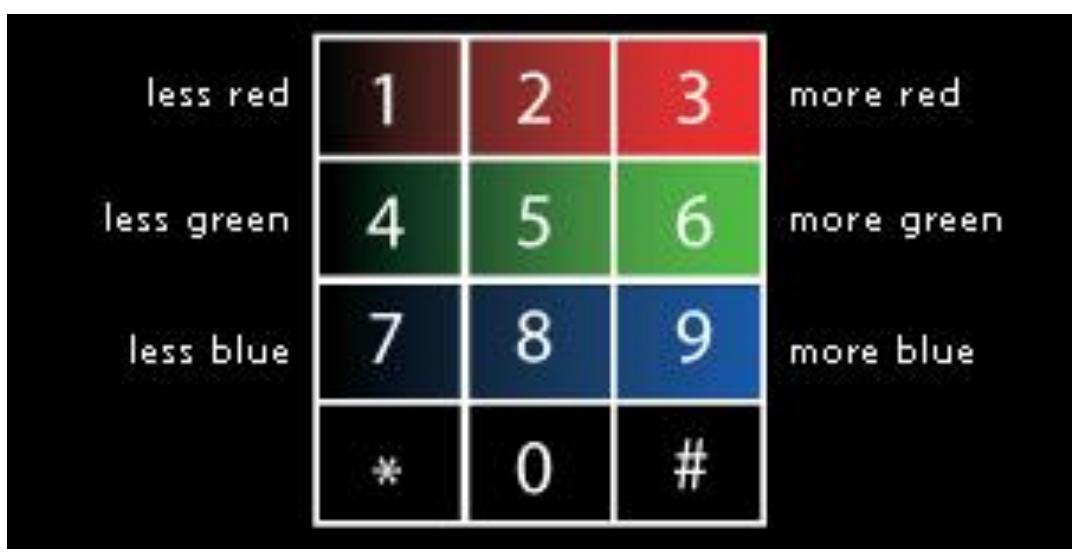

Figura 73: Gráfico que representa o controle de cores pelo teclado do celular. Fonte:

<www.colourbynumbers.org> 
Para interargir com a torre por meio de seu celular o participante precisava primeiramente ligar para o número de telefone associado ao projeto, em seguida, pressionando os números de 0 a 9, escolhia os andares para a intervenção. Uma vez escolhido o andar pressionava o sinal “\#” permitindo que fosse definida a modulação das cores do andar pré-defindo. Para definir a cor, o participante alterava os níveis das cores aditivas primárias pressionando os números de 1 a 3 para definir a intensidade de vermelho, de 4 a 6 para a de verde, e de 7 a 9 para a do azul. Ao finalizar ele pressionava “*” para definir um novo andar ou “\#” para encerrar a sua intervenção. Cada participante tinha direito a uma intervenção de 5 minutos a contar do início de sua ligação de modo a permitir que outras pessoas pudessem de igual modo participar. A modulação realizada pelo usuário, por agir diretamente nas bases da mistura aditiva, permitia a realização de infinitas configurações de cores pelo participante.

Os dispositivos tecnológicos envolvidos na realização dessa obra eram: o aparelho celular do participante, um computador com acesso à Internet, os LEDs (Diodos Emissores de Luz - diodo semicondutor que quando energizado emite luz) de três cores (vermelho, verde e azul) instalados por trás de cada uma das janelas do edifício, e também a interface criada que possibilitou a conectividade entre os comandos emitidos pelo celular, os dados enviados pela Internet e o recebimento das informações no prédio.

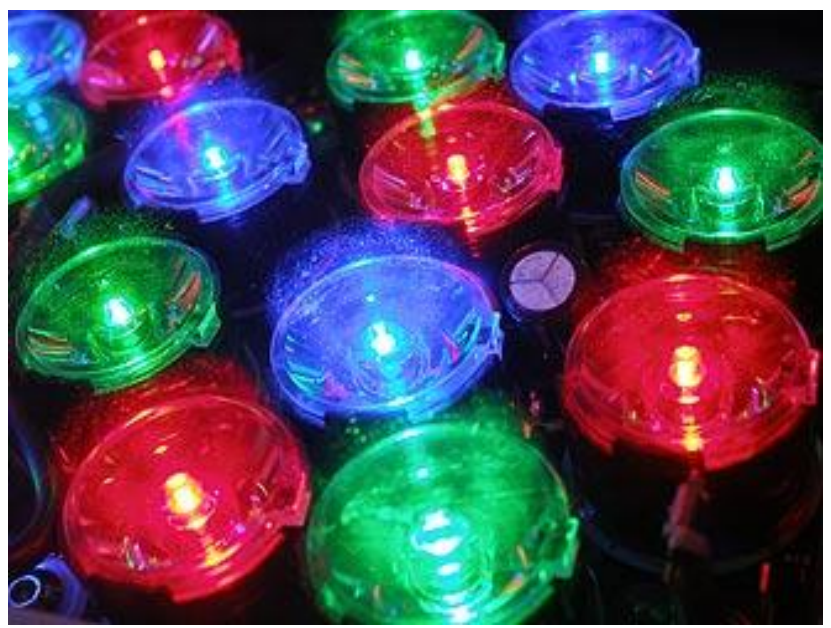

Figura 74: LEDs que foram posicionados nas janelas do edifício.

Fonte: <www.colourbynumbers.org> 


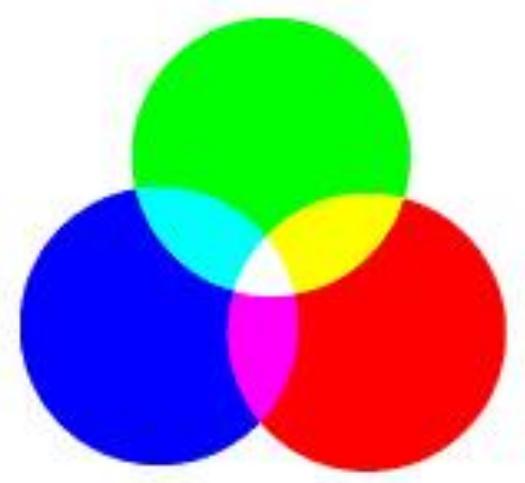

Figura 75: Gráfico que representa a mistura aditiva das cores.

Fonte: Gráfico de acordo com Pedrosa (2009, p.23)

Para os autores do projeto, a forma definida para a obra, como uma torre com pontos iluminados, chamou a atenção do público que eles queriam captar. Pessoas comuns, pedestres atraídos pelas cores e pela luz queriam compreender a mensagem ou fazer parte dela. A torre passou a ser um meio de comunicação, transmitindo mensagens enviadas pelo público, interferindo no cenário urbano. E essas mensagens "faladas" pelo edifício foram expressas por uma linguagem composta de luz. Os autores, ao proporem a obra, queriam discutir questões relacionadas ao espaço público, permitindo ao pedestre ou habitante daquela cidade participar da construção desse espaço até então dominado pelas interferências urbanas de cunho comercial. A obra deu ao participante uma oportunidade de se comunicar por meio das cores e enviando sua mensagem para a cidade.

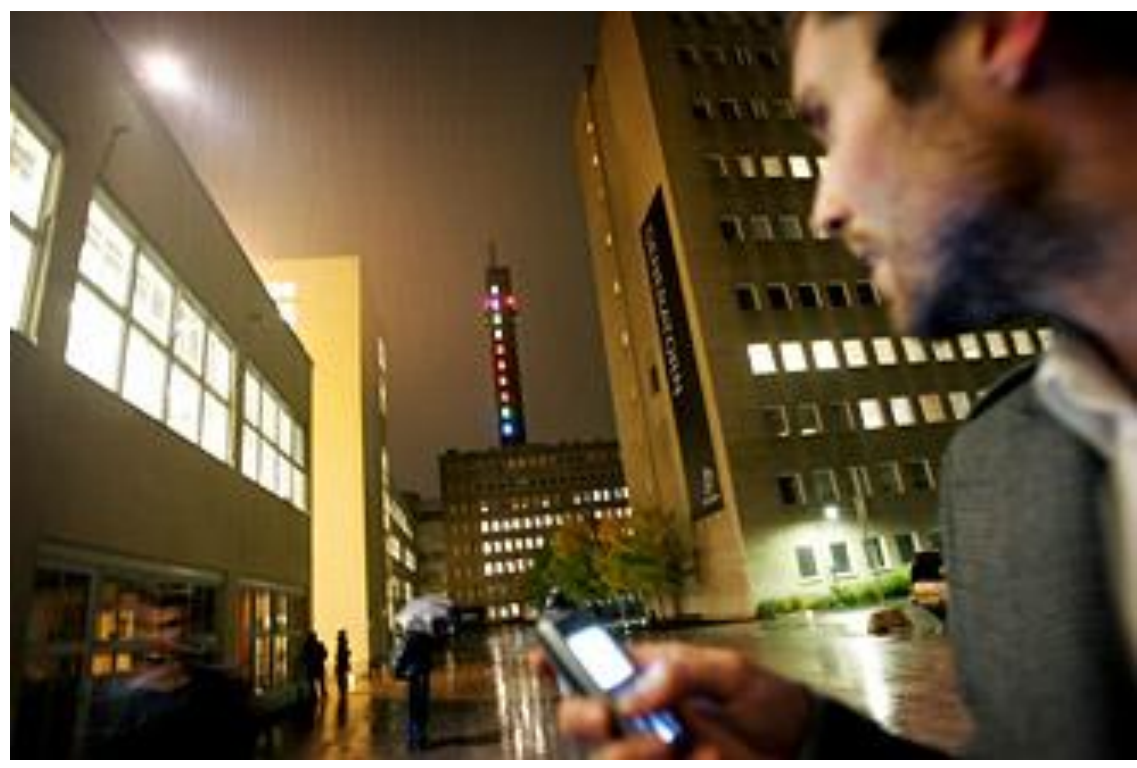

Figura 76: Participante interagindo com a torre através do celular. Fonte: <www.colourbynumbers.org> 
Por ser uma obra reativa, criada com base nas mídias digitais, Colour by Numbers não faria sentido sem a interação com o público, assim como os próprios autores enfatizaram: "Sem as pessoas participando, e ativamente fazendo parte da criação da obra, não existiria nada”. Os participantes tinham em mãos artefatos do dia a dia que se transformaram em ferramentas para alterar o cenário urbano. As especificidades do meio em que a obra estava inserida proporcionaram ao participante diferentes maneiras de se expressar pela combinação de cores e pela criação de mensagens singulares. As combinações de cores naquele espaço de 10 janelas eram múltiplas, sendo que cada cor possuia sua própria característica ao ser formulada a partir das três cores básicas.

É possível dizer que quem vizualizou aquela informação emitida pelas janelas da torre se sentiu instigado a traduzi-la e dela fazer parte, sabendo que por cinco minutos teria o domínio total sobre o que a torre estivesse comunicando. Movido por uma atitude exploratória, por um curto espaço de tempo acessou as janelas e pode verificar como suas interferências foram traduzidas visualmente por meio de informação cromática no cenário da cidade. Sem regras para isso, o participante teve a liberdade de determinar, com base em seus sentidos e intelecto, a combinação de cores, transformando e fazendo parte da obra.

Esta obra, por seu efeito instantâneo e por fazer parte das novas tecnologias da comunicação permitiu ao participante, mais do que participar, interagir com a obra. Na interação da obra se percebe, um dialogo de "realimentação circular" entre interator e obra de caráter exógeno e instantâneo. Apesar desta obra possuir um caráter controlado e reativo, no que tange a predeterminação espacial e a tradução por meio da cor, percebe-se a possibilidade de os participantes atualizarem, dentro daquele formato sugerido pelo artista, livres formas de se expressar. São milhares as combinações de cores possíveis e múltiplas as leituras de que delas decorrem, permitindo, o que antes foi dito por Plaza (2003, p.17) sobre a "comunicação criadora", que os participantes realmente interfiram na mensagem da obra colaborando construtivamente de maneira "crítica e inovadora". 
A participação individual que caracteriza esta obra foi definida de forma que o participante, por alguns instantes que fosse, pudesse ter o exclusivo domínio sobre ela, fato este que não tira seu caráter social e urbano de permitir atingir o maior número de pessoas pela mensagem emitida. A saída do museu é justamente uma estratégia de se pensar e trabalhar com o social. Para os autores da obra a "arte possui um potencial muito maior quando integrado na sociedade" entrelaçando-se assim com o "fluxo de vida cotidiana". Ainda de acordo com os autores, o local definido para a instalação, Midsommarkransen, foi eleito não só por sediar a Ericsson, mas também devido a sua localização em um subúrbio da cidade de Estocolmo, ajudando a inverter a situação periférica da cidade. Fazendo parte da cidade, a obra chama a atenção do coletivo, da sociedade através do individual, dos habitantes que, por intermédio do edifício, interferiram no cenário de sua cidade.

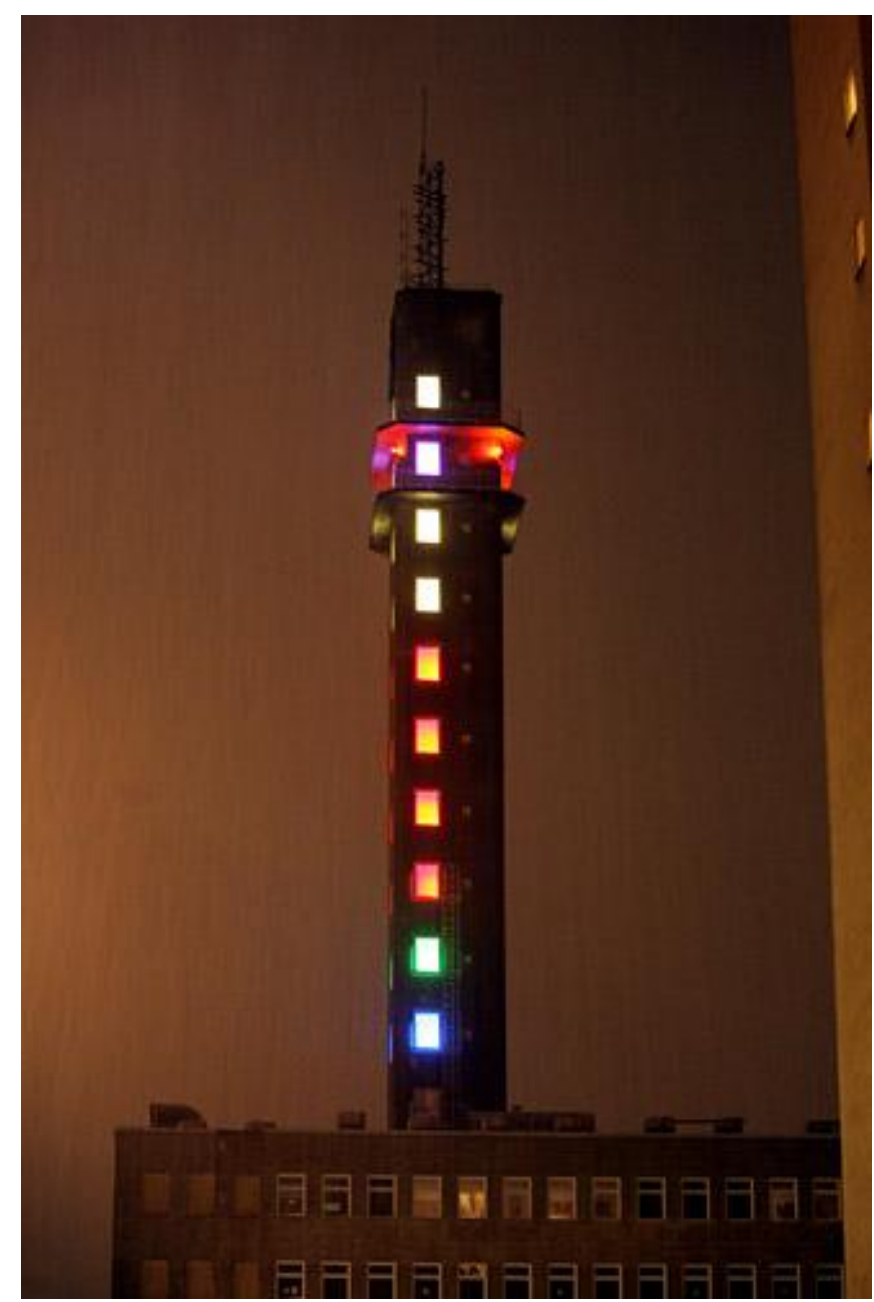

Figura 77: Edifício Telefonplan no período em que a obra estava ativa. Fonte: <www.colourbynumbers.org> 
O uso da cor como fonte luminosa em uma instalação é financeiramente mais viável do que se fossem utilizados outros meios de comunicação. Nesta obra a luz emitida pelos LEDs na janela de cada andar permitiu que a fachada do edifício fosse alterada sem que fosse necessário modificar o seu corpo estrutural. A outra grande vantagem que se percebe atrelada ao uso desse tipo de tecnologia é que ao se emitir luz de um certo ponto, como no caso das janelas, essa luz consegue percorrer uma grande distância sem perder o seu referencial cromático. Muitos moradores daquela região conseguiam avistar a torre de longe, permitindo-lhes participar e acompanhar a emissão de qualquer ponto daquela região (salvo os casos em que alguma outra edificação obstruísse a visão). A escuridão do inverno de Estocolmo também contribuiu para o efeito e alcance da luz e a comunicação com a cidade. O contraste entre a luz e a escuridão do ambiente transmitia à obra força, tornando a identificação das cores muito mais fácil.

De acordo com os autores, a torre falava por meio de uma língua de sinais composta pela cor da fonte luminosa. Não era apenas um mecanismo que permitia às pessoas vivenciarem uma experiência lúdica juntamente com a tecnicidade, a cor tinha a sua contribuição como linguagem a ser explorada pelos participantes e pela sociedade. Era uma possibilidade de intervir no cenário urbano e expressar por meio de padrões e cores a sua mensagem. De acordo com Bydler, os sinais luminosos advindos da torre vinham "de dentro", as pessoas passaram a ter a oportunidade de influenciar parte do cenário urbano, mesmo que por um breve período.

“[...] Architecture is a mass medium, but the tower's message is individual. Someone is holding the controls, pushing buttons for commands and showing their colours. But this 'someone' can't use the tower for political or commercial purposes. What remains is a playful communicative process that takes over the public space as the colours change. [...]"9 BYDLER

\footnotetext{
9 “Arquitetura é um meio de massa, mas a mensagem da torre é individual. Alguém está no controle, apertando botões para comandos e mostrando suas cores. Mas esse "alguém" não pode usar a torre para fins políticos ou comerciais. O que resta é um processo lúdico de comunicação que toma conta do espaço público à medida que as cores mudam”. (T.A.)
} 


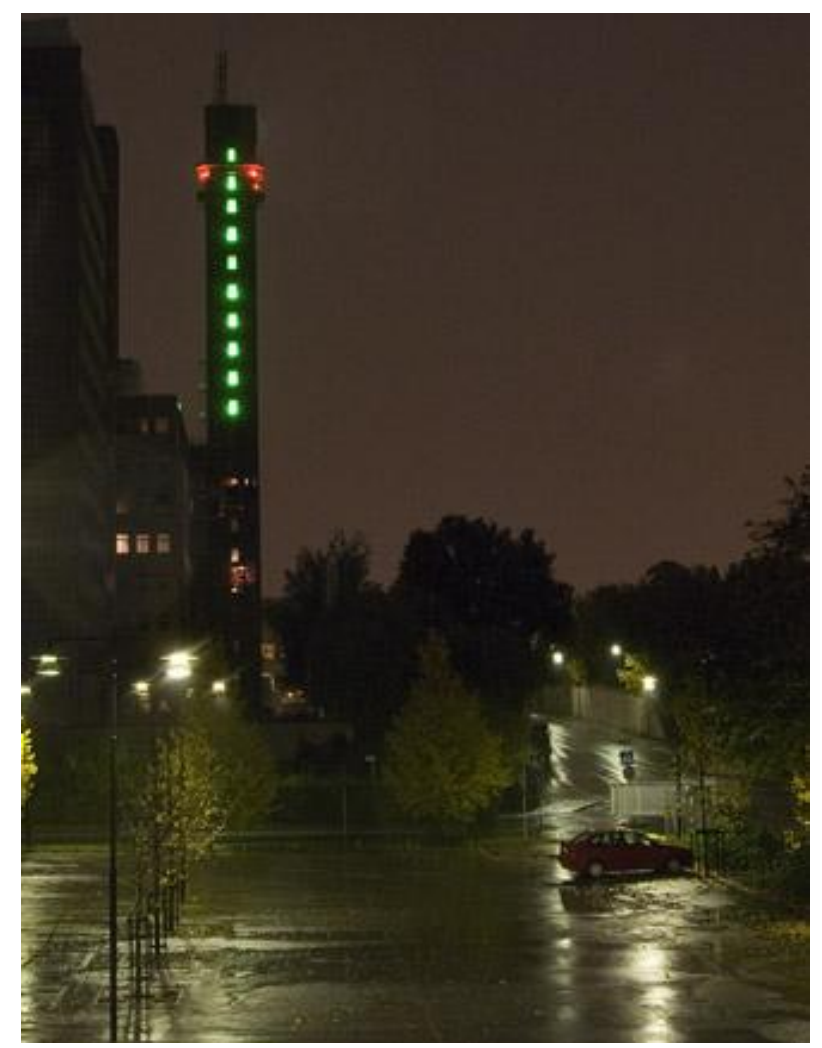

Figura 78: Edifício Telefonplan no período em que a obra estava ativa.

Fonte: <www.colourbynumbers.org>

A torre não dominava fazendo o individuo emergir completamente em sua luz, mas ela certamente se sobressaía, com suas janelas iluminadas na escuridão do inverno. Portanto ela esteve ali naquele cenário promovendo a quem estivesse disposto a participar uma oportunidade de se comunicar com a cidade. A sua posição e formato não permitiam uma imersão em sua luz, mas uma ligação sensível com o que ela representava tanto para o participante quanto para a comunidade. 


\subsubsection{Forest of Light ${ }^{10}$}

A instalação Forest of Light, de autoria de Christina Mejborn e Line Langballe, do escritório Totem Collective, foi concebida para acontecer durante um fim de semana, vinculado ao evento CO2penhagem em Setembro de 2009 na Dinamarca. A obra foi arquitetada para se situar de frente para uma área de floresta de 50 metros quadrados, próxima ao local do evento. A estrutura, posicionada de frente para a área da floresta, consistia em uma treliça de 60 metros de altura situada sobre uma plataforma interativa de $60 \mathrm{~m} \times 45 \mathrm{~m}$. Na base dessa plataforma estavam 20 troncos de árvore cortados que serviam como bases ou pedestais interativos. No alto, suspensas pela treliça, estavam duas lâmpadas e uma webcam adaptada com um sensor infravermelho que tinha o papel de correlacionar qualquer movimento realizado sobre os troncos com uma das 20 lâmpadas de LED (GLP impression lamp) correspondentes que projetariam luz colorida em uma das árvores no interior da área da floresta.

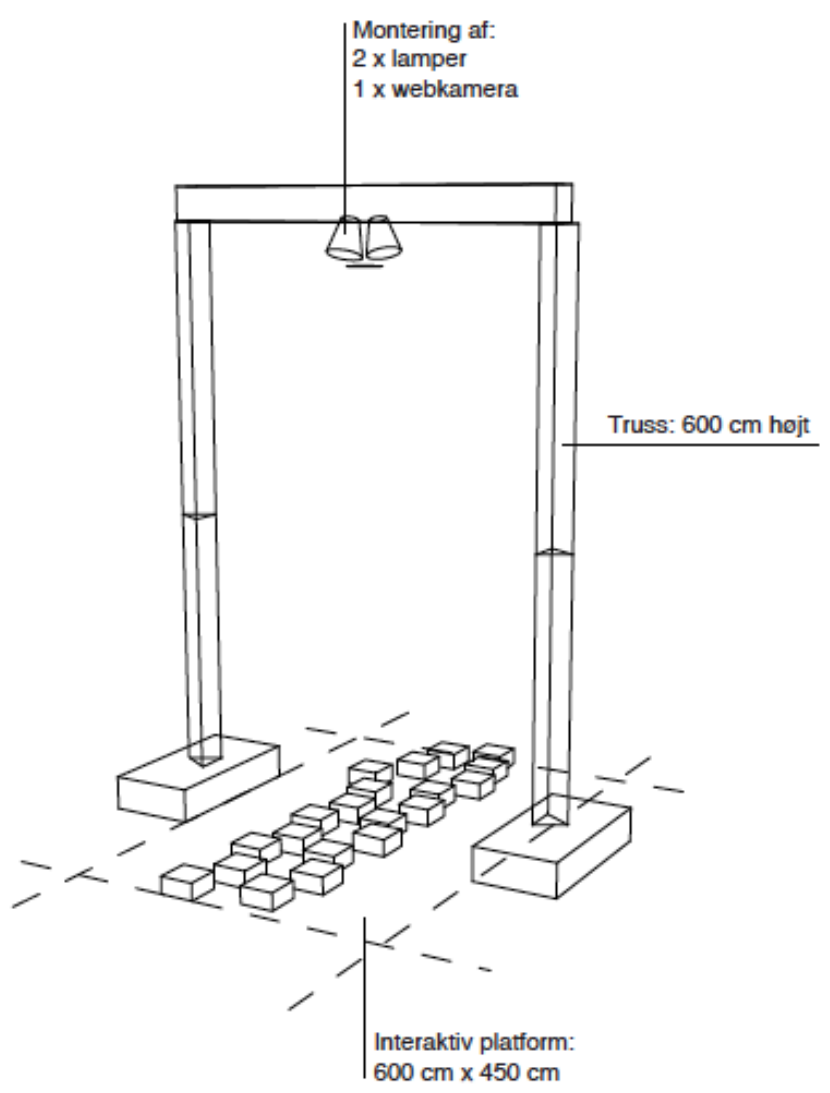

Figura 79: Gráfico estrutural da obra Forest of Light.

Fonte: Imagem gentilmente cedida por Christine O. Mejborn, da Totem Collective.

${ }^{10}$ Disponível em: <www.totemcollective.com>. Último acesso em: 24/08/10. 
Todo e qualquer sinal de movimento capturado pela webcam por um sensor infravermelho seria enviado para um banco de dados cuja função era traduzir os dados de movimentação em luz. Dessa forma cada um dos 20 troncos estaria interligado, via sensor, a uma lâmpada específica de LED espalhada pela área da floresta. Cada uma das lâmpadas de LED poderia, de acordo com sua estrutura e composição, reproduzir qualquer outra cor do espectro pela mistura aditiva das cores vermelho, verde e azul.

No gráfico a seguir é possível acompanhar o projeto inicial para a obra Forest of Light. Nele se percebe o mecanismo da webcam ao identificar o posicionamento do participante sobre a superfîcie do tronco e emitir os dados dessa movimentação para o banco de dados.

A respeito dessa proposta inicial feita pelas autoras, nota-se um refinado mecanismo no controle da cor. Em primeiro lugar foi definido que o matiz da luz a ser projetada seria definido pelo banco de dados da obra de maneira aleatória. Porém dados como valor e croma poderiam ser controlados pela movimentação sobre a área dos troncos. O sensor infravermelho da webcam identificaria quatro pontos opostos na área dos troncos que regularia a cor projetada, conforme a presença e o movimento humano. De acordo com o gráfico, se o participante se movimentasse da esquerda para a direita ele definiria o croma da cor a ser projetada. Dessa forma seria possível alterar a saturação e a força do matiz que era aleatoriamente definido pelo banco de dados da obra. Outra mudança definida pela movimentação seria no sentido da vertical, para cima e para baixo, definindo o valor da cor a ser projetada. Assim, seria possível notar um aumento e uma diminuição da luminosidade da cor projetada.

Se, por exemplo, conforme o gráfico a seguir, quando um participante subisse até um tronco qualquer sobre a plataforma interativa, a câmera identificaria sua presença e traduziria esse comando, que aleatoriamente definiria um matiz a ser projetado na árvore (no gráfico a seguir percebemos ser o azul). O participante então assumiria o controle dessa cor definindo o seu valor e croma, movendo-se sobre a área dos troncos. Essas movimentações seriam percebidas e transcodificadas imediatamente. 


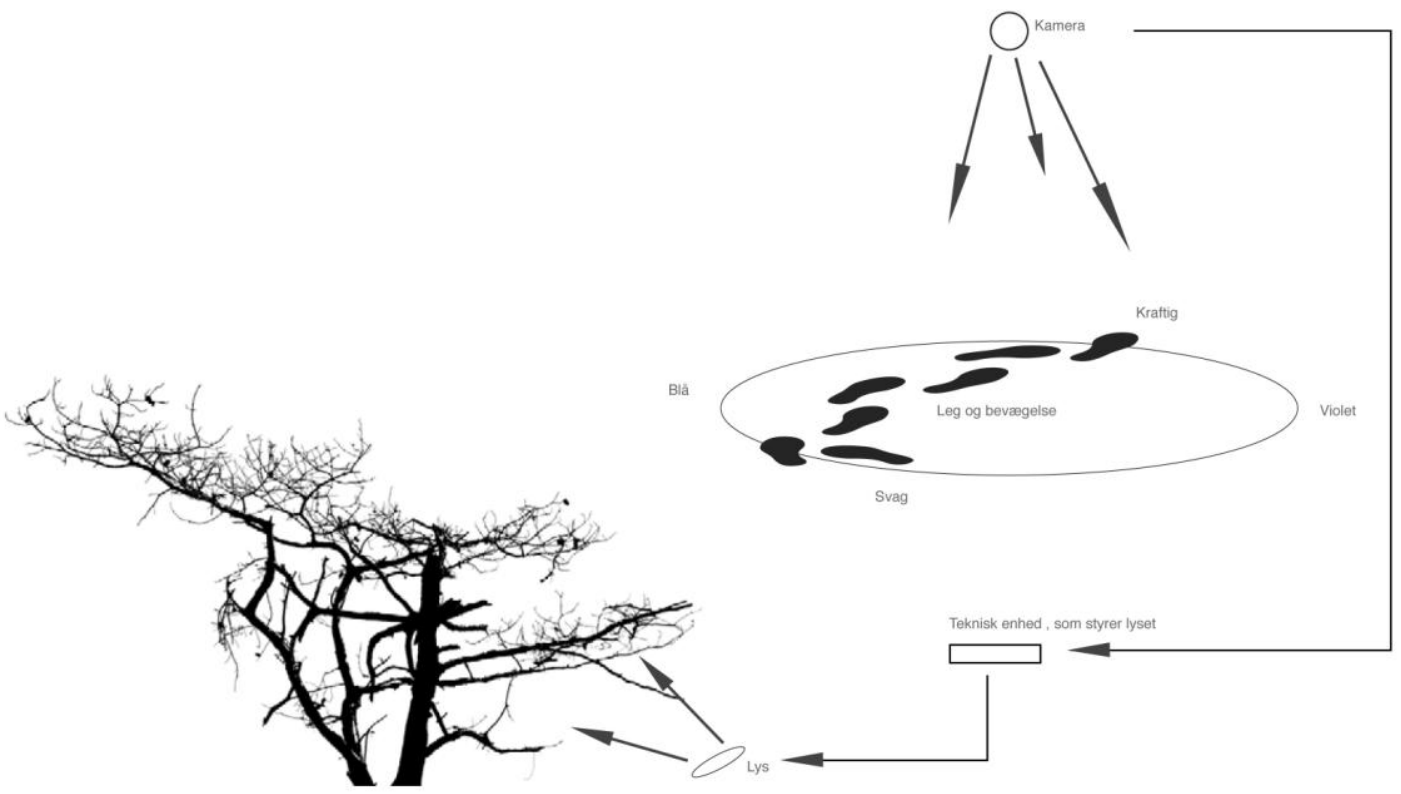

Figura 80: Gráfico estrutural da obra Forest of Light.

Fonte: Imagem gentilmente cedida por Christine O. Mejborn, da Totem Collective.

No entanto, o mecanismo até aqui exposto, que permitiria ao usuário definir o croma e valor de cada matiz, não foi efetivado quando a obra foi colocada em funcionamento. $\mathrm{O}$ que ficou estabelecido seria que a webcam iria detectar apenas a presença do participante, ativando conforme sua presença uma lâmpada de LED na floresta seguindo um comando aleatório na definição do matiz.

O que motivou essa mudança, de acordo com uma das artistas, foi a vontade de se simplificar o mecanismo da obra, facilitando o entendimento do participante sobre seu funcionamento. Se houvesse um controle meticuloso de croma e valor, o visitante correria o risco de não identificar todas essas potencialidades em um primeiro contato. É preciso considerar que essa obra foi pensada para um período de execução extremamente curto de dois dias e durante um evento. Os visitantes do evento talvez não tivessem tempo suficiente para apreender todo o mecanismo e não teriam a oportunidade de decifrar a obra por completo. A autora cita um exemplo comparativo de uma máquina de lavar: se ela possui muitos botões e a intenção da pessoa for apenas lavar a roupa, essa quantidade extra de informações poderia atrapalhar ou desestimulá-la a chegar ao seu objetivo, que no nosso caso seria o de conhecer a obra apreendendo a proposta poética do artista. 
Essa obra convida então não apenas um, mas diversos participantes a interagir simultaneamente, ativando por meio de seus movimentos diferentes pontos luminosos na floresta à sua frente. A obra instiga o participante a assumir um olhar exploratório e interrogativo por não possuir referências ou indicações do que pode vir a acontecer durante o acionamento dos diversos troncos. Dessa forma percebe-se, por parte dos participantes, uma atitude experimental na exploração e no modo de compreender o mecanismo de detecção de movimento e de mudança de cores projetadas. Eles perceberão durante essa exploração do espaço que a cor associada a um tronco nunca será a mesma, sendo modificada aleatoriamente, e verá que o resultado alcançado será mais grandioso dependendo do número de pessoas que com ele compartilharem aquele espaço interativo.

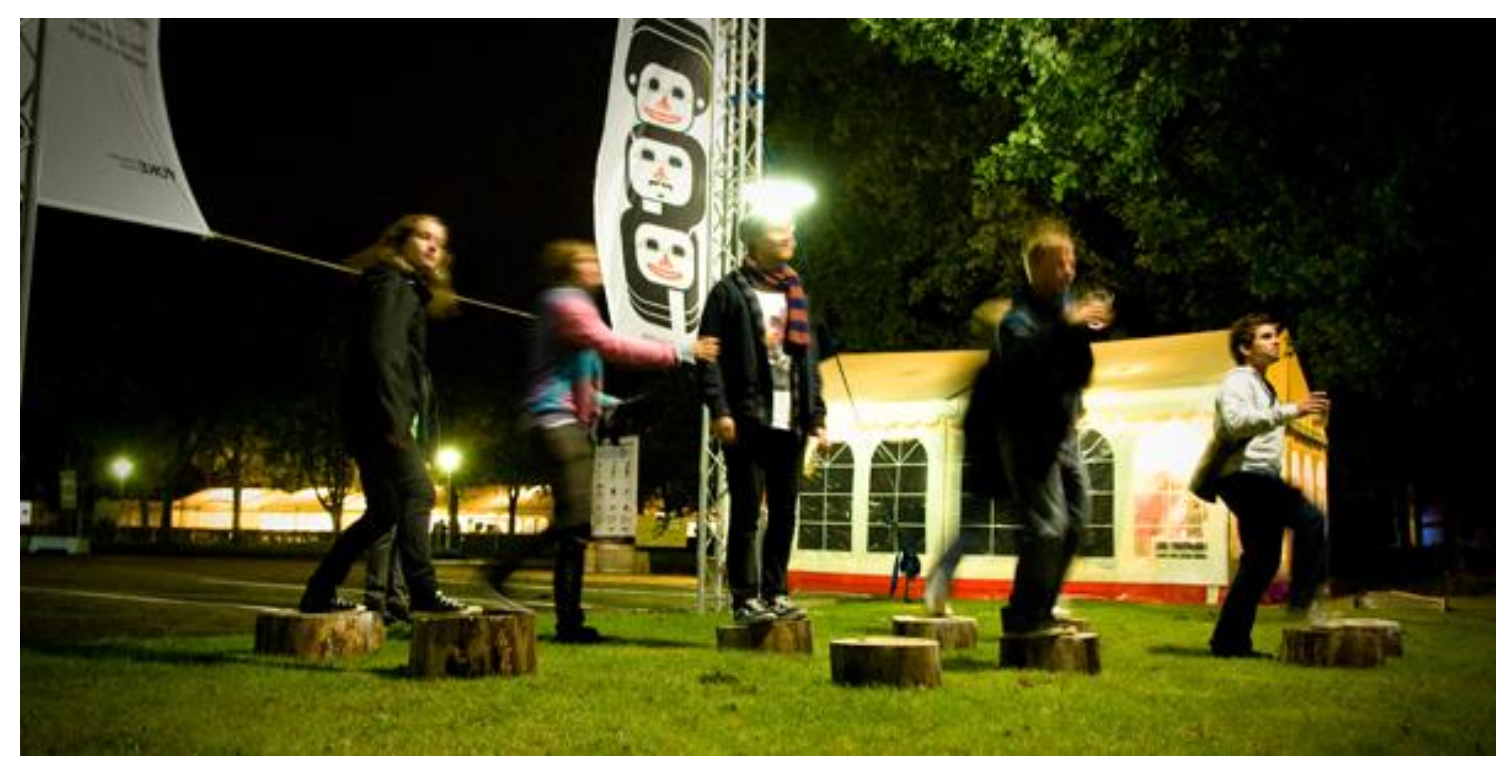

Figura 81: Participantes acionando a obra por meio de seu movimento.

Fonte: <www.totemcollective.com>

A característica não linear e interativa da obra permite a criação de diversas configurações na maneira de se projetar a cor. Nesse caso, ela reagirá aos movimentos dos participantes respondendo de maneira circular e exógena com a seleção aleatória de um determinado matiz de cor, que permanecerá projetado enquanto o participante estiver disposto a estender esse diálogo. Esse caráter instantâneo da obra se reflete na capacidade de responder às ações dos receptores, convertendo os dados provenientes do movimento em informação numérica, que por sua vez é convertida pelo sistema do banco de dados em cor de fonte luminosa pelas lâmpadas - três intensidades diferentes para as respectivas cores vermelho, verde e azul contidas no LED de forma a projetar, 
por meio de mistura aditiva, uma determinada cor. Outra qualidade da obra devida ao seu caráter instantâneo é sua capacidade de subverter os tradicionais meios de comunicação entre emissor, receptor, mensagem e canal de comunicação, promovendo uma circularidade e um entrelaçamento dessas entidades. Apesar do fato de haver uma aleatoriedade programada no mecanismo de diálogo com o participante, percebe-se uma interação de caráter reativo. Neste caso o participante se condiciona a acionar um mecanismo que aleatoriamente alterará as cores, mas que por ser randômico induz o participante a pensar que existirão sempre novos caminhos a serem explorados.

A obra Forest of Light nos faz refletir no quanto uma participação individual comparada a participação coletiva contribui para a construção de uma informação. A participação individual certamente permitirá se alcançar um efeito monocromático (relativo a um matiz) e reduzido em dimensões. Seria algo impraticável o indivíduo sozinho conseguir estar sobre dois troncos ao mesmo tempo. A participação coletiva irá se refletir na ampliação do dialógo e no consequente aumento da área iluminada pelas luzes coloridas das lâmpadas de LED, representadas em diferentes matizes. Se levarmos em conta que duas pessoas podem saltar entre os troncos dessa plataforma, teremos dois focos alternados de luz colorida refletidos na floresta, mas se o número de participantes aumentar e eles trocarem de posições, será percebida uma variação e uma multiplicidade de cores e projeções nas árvores, uma verdadeira sinfonia de cores. No entanto, se vinte pessoas participarem e ocuparem os exatos vinte troncos disponíveis na plataforma interativa, se perceberá uma imagem estática de 20 cores sendo projetadas simultaneamente sem nenhuma variação de cor aparente, apenas sendo possível alcançar esta modificação quando dois (ou mais) indivíduos trocarem de posição e alterando então a cor de dois (ou mais) pontos de luz nesse cenário. Portanto, o acesso coletivo enriquece a exploração por novas projeções no cenário da floresta, dando margem a diferentes possibilidades de combinação que nunca serão as mesmas, uma vez que a obra trabalha com a aleatoriedade na seleção dos matizes. Percebe-se uma tendência positiva na parceria e na construção do significado da obra no campo do subjetivo. 


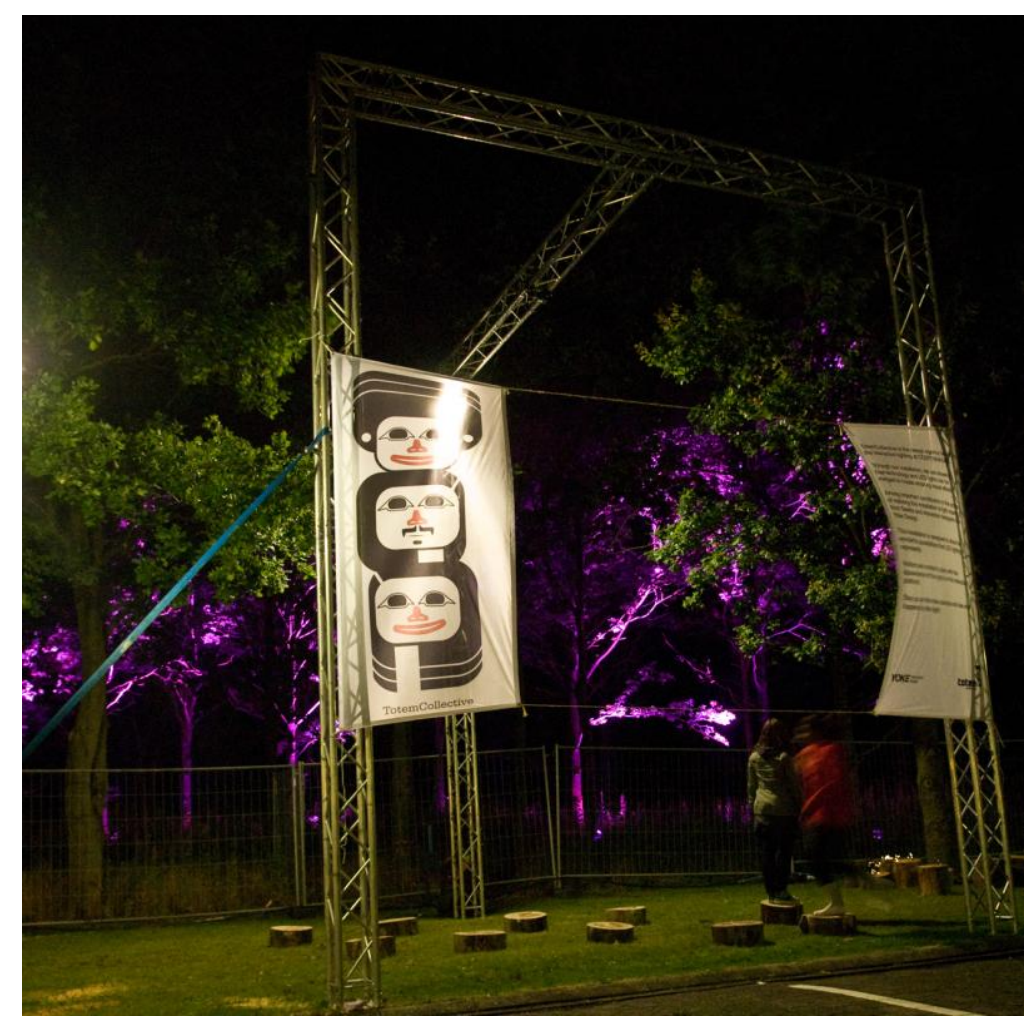

Figura 82: Participantes acionando a obra por meio de seu movimento. Fonte:

<www.totemcollective.com>

O efeito causado pela projeção das cores nas árvores ao invés da emissão por meio de outros dispositivos desvincula a atenção do objeto emissor de luz para um outro foco, a floresta. Não seria possível de outra forma alcançar o efeito produzido nas árvores sem que houvesse a projeção. As árvores se tornam cenário e dão forma material à cor da fonte luminosa, agregando a ela um efeito natural, trazendo vida e credibilidade àquelas cores, como se fizessem parte integrante da floresta. As cores se diluem na floresta e delineiam as folhas e galhos das árvores em um ambiente onde a escuridão é reinante. $\mathrm{O}$ receptor, desta maneira, experimenta o inteligível de modo tangível na obra.

A ênfase no caráter exploratório da obra nos faz perceber que o seu objetivo não é apenas a composição final formada pelas cores projetadas, mais que isso, por ser reativa, percebe-se um interesse pelo seu processo de criação artística e de exploração estética. Conforme Plaza (2003, p.17), essa é uma atitude que demonstra o interesse dos artistas pela realização de obras abertas "onde a percepção, as dimensões temporais e espaciais representam um papel decisivo [...]". O movimento é assim traduzido em cor como fonte luminosa criando um ambiente em que se sugere uma dada significação. $\mathrm{O}$ corpo traduz seus movimentos em informação visual, indo ao encontro da poética proposta de se criar uma atmosfera de sentidos por meio das cores provenientes de fonte luminosa. 


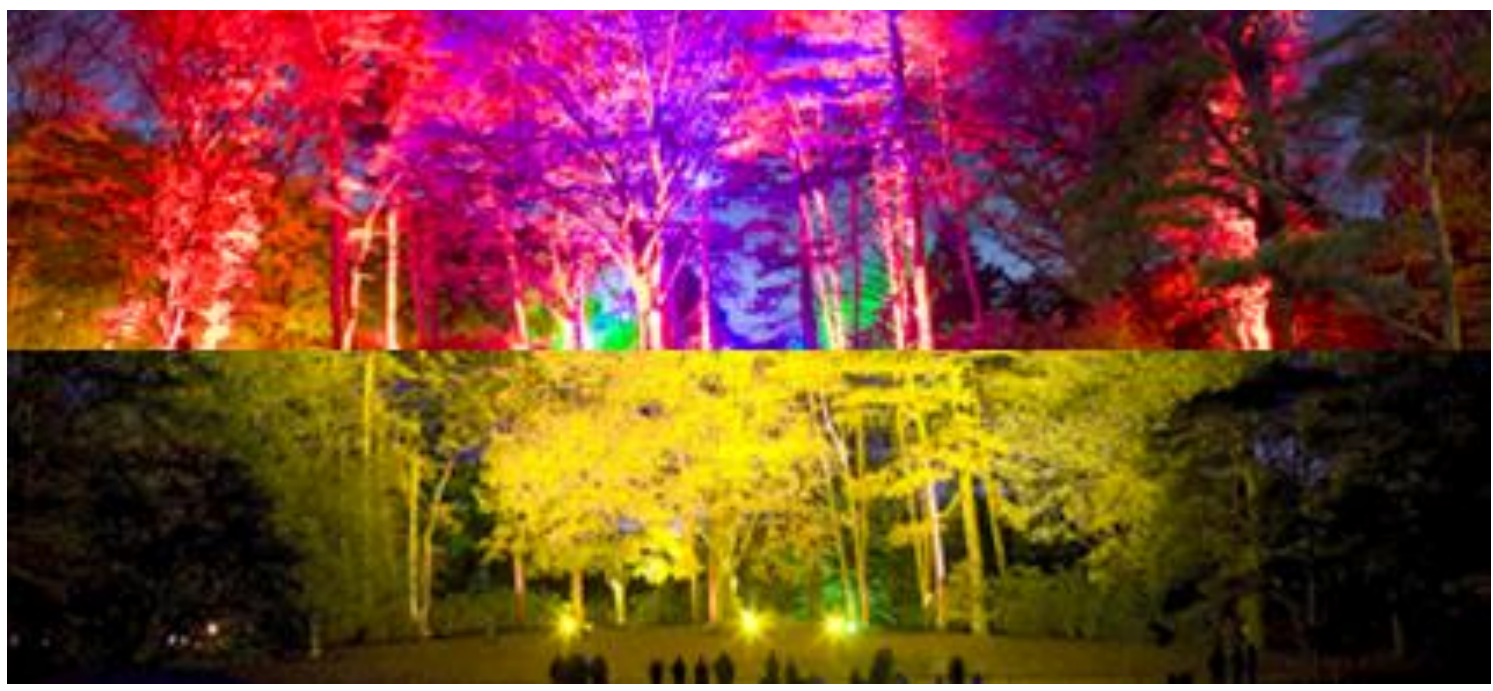

Figura 83: Floresta iluminada pelas projeções de luz. Fonte: <www.totemcollective.com>

A significação atribuída à obra se reflete nos efeitos produzidos pela cor ao atingirem o cenário da floresta. A obra não atribuiu uma significação ou explicação para o por que das cores utilizadas. Porém, devido à projeção das cores nas árvores engrandecer o efeito colorido luminoso na escuridão da noite, tem-se a impressão de que as cores alcançam um nível quase material e tangível, nos dando a sensação de estarmos imersos naquela orquestra de cores e luz. Como se o dispositivo técnico potencializasse a "interação", a "interatividade" e a "multisensorialidade" entre a arte e a tecnologia, promovendo a exploração de dados "perceptuais, cognitivos e interativos", conforme nos diz Plaza (2003, p.17). A cor de fonte luminosa é então ferramenta para inserir poeticamente o receptor na obra. 


\subsubsection{D-Tower ${ }^{11}$}

A obra D-Tower, de autoria do artista Q. S. Serafijn ${ }^{12}$ em parceria com o arquiteto Lars Spuybroek $^{13}$, foi projetada para que ficasse em exibição entre os anos de 2004 e 2011 na cidade de Doetinchem, na Holanda, adornando um dos seus pontos turísticos na cidade antiga. A torre iria medir as emoções dos habitantes da cidade todos os dias através de quatro diferentes cores. A obra constitui-se de três partes, quais sejam: uma torre, um website e um questionário interligados.

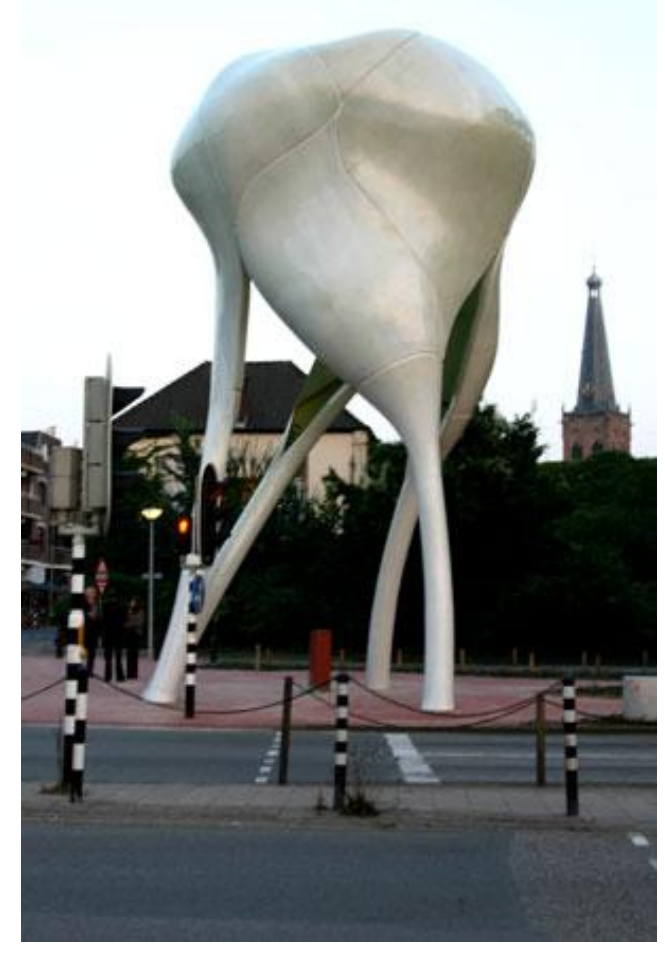

Figura 84: D-Tower.

Fonte: <www.nox-art-architecture.com>

Foi em 1998 que o conselho da cidade de Doetinchem convidou o artista Q.S.Serafijn para fazer a primeira de quatro torres, que faria parte de um projeto chamado Between Rock and Cloud (Entre Pedra e Nuvem) que consistia na criação de esculturas que representassem os temas fogo, água, ar e terra, e que ficariam expostas próximas aos portões da cidade antiga. A primeira escultura, representante do fogo, foi destinada ao artista Q.S.Serafijn, que naquele período vinha trabalhando com obras de cunho tecnológico e que permitiam a interação com o público urbano.

\footnotetext{
11 Disponível em: <www.d-toren.nl>. Último acesso em: 09/07/10.

12 Artista de Rotterdam, responsável pelo desenvolvimento do conceito sugerido da obra.

13 Arquiteto de Rotterdam, do escritório de arquitetura NOX Architekten, responsável pela execução da torre e de sua interface.
} 
O artista então estabeleceu que sua escultura seria "interativa", envolvendo a ação do público no funcionamento da obra. A proposta poética do artista para a obra foi a de mapear a comunidade "dobrando-a" sobre ela mesma, fazendo-a refletir sobre as pessoas e a própria cidade.

De forma conjunta com o arquiteto Lars Spuybroek, o artista estabeleceu que a função da torre seria a de medir os sentimentos da cidade. De acordo com a fala do artista, a parte mais intrigante e interessante do projeto foi pensar em como fazer com que a torre refletisse esses sentimentos, "como se fossem os batimentos cardíacos da comunidade." $\mathrm{O}$ artista e o arquiteto pensarem em conjunto sobre o mecanismo que possibilitaria medir esses sentimentos e como exibir tais resultados.

Foi definido que a torre serviria como um "termômetro" que, estabelecido em um ponto central da cidade, traria à superfície seus sentimentos. Para que fosse possível obter esse índice de emoção dos habitantes de toda a cidade, da maneira mais acurada possível, o artista e o arquiteto concluíram que seria necessário um questionário. Ficou decidido desta forma que esse questionário se responsabilizaria em medir quatro tipos diferentes de sentimento: amor, felicidade, medo e ódio. Assim, algumas questões seriam liberadas diariamente aos participantes durante um período de 6 meses $^{14}$. Essas questões deveriam ser acessadas pelo website do projeto, no qual os habitantes da cidade interessados em participar se cadastrariam para que começassem a receber os e-mails com as questões. No website existiria um gráfico, construído a partir dos dados obtidos pelo questionário, que sinalizaria de maneira detalhada - para cada região da cidade - os altos e baixos das emoções medidas em cada dia. A torre, que também receberia os mesmos dados dos questionários, iria associar a média de emoção da cidade - calculado por um computador central - a uma determinada cor. Todas as partes do projeto estariam interligadas executando a mesma função de conhecer os moradores de Doetinchem e fazê-los refletir sobre seus sentimentos.

\footnotetext{
${ }^{14}$ Período de execução de cada etapa da obra. A cada seis meses aconteceria novamente, somando-se duas execuções por ano.
} 
A estrutura da torre foi projetada pelo arquiteto e supervisionada pelo artista, e alcançou 12 metros de altura. O material utilizado para a composição da torre foi o epóxi com fibra de vidro laminado, resistente o suficiente para mantê-la em funcionamento durante um tempo de exposição de sete anos. Sua estrutura é composta por dezenove partes desenvolvidas a partir de moldes usinados em espuma de poliestireno.

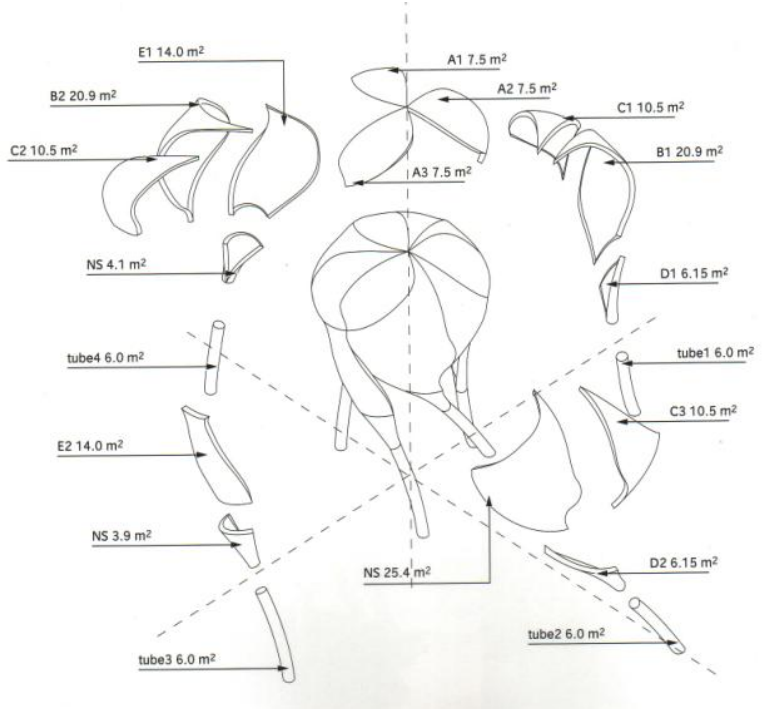

Figura 85: Estrutura da torre em vista explodida.

Fonte: (SPUYBROEK, 2004, p.162)
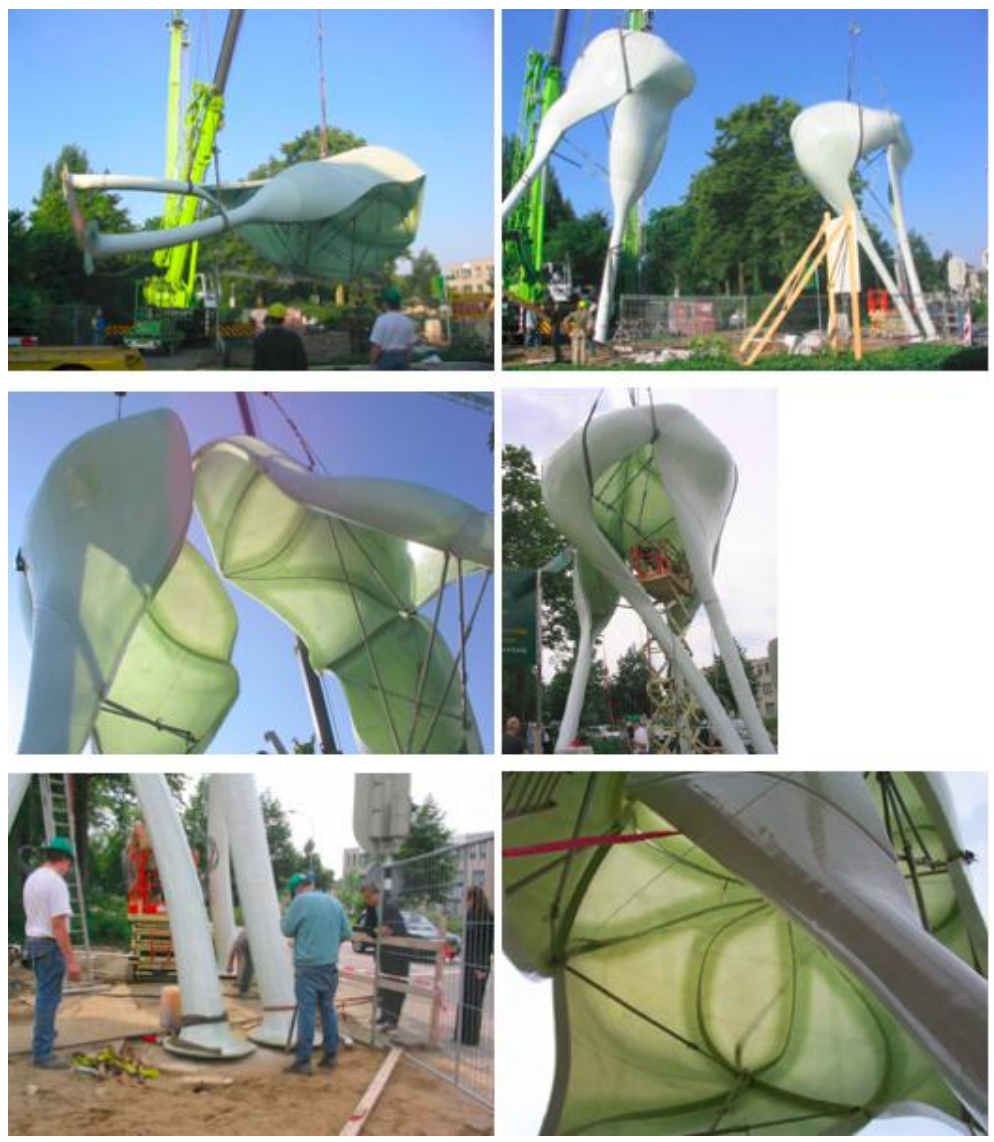

Figura 86: Fases da construção. Fonte: 〈www.arcspace.com> 
Foi em razão de Q.S.Serafijn ser um "artista conceitual”, não possuindo o domínio das práticas de execução de um arquiteto, que o artista buscou parceria com Lars Spruybroek, que se ocupou da construção física da torre, bem como do desenvolvimento de seu mecanismo e funcionamento.

Essa parceria sugere que, com o acelerado desenvolvimento da tecnologia e do vasto número de dispositivos oferecidos pelo mercado, haverá cada vez mais interação entre diferentes áreas do conhecimento. Os artistas, por exemplo, se associam a engenheiros, arquitetos e, ultimamente, no que se refere aos trabalhos mais recentes com mídias digitais, é possível notar a parceria com programadores e designers de interação.

Esta associação ou parceria, no caso da D-Tower, se tornou algo além do uso de uma determinada tecnologia ou instrumento, mas de uma coautoria, trabalhando o arquiteto em conjunto com o artista na construção poética da obra e dando respaldo na sua viabilidade técnica durante todo o seu desenvolvimento.

"I always enter into projects as 'blankly' as possibly and allow many decisions to be determined by practicality. Reality is obstinate. This is another way of planning: it is not the original goal that determines a project's quality, but the process. As an artist I do not have a typical style or oeuvre. In my projects I work mainly 'undercover'. For me, art is a means rather than an end, I link different kinds of expertise. The project is central and in it I make generous use of the knowledge and experience of others present. But I do keep control of the direction of the project." ${ }^{15}$ (SERAFIJN, 2005, p.42)

Para o desenvolvimento do questionário foi necessário um meticuloso trabalho, por parte do artista, para que fosse possível avaliar o que realmente se passava pelas mentes dos participantes/habitantes. Uma das restrições imposta pelo projeto seria a de que a participação fosse limitada apenas aos moradores, fato esse que encontra justificativa em sua proposta poética de trabalhar o comportamento da cidade.

\footnotetext{
15 'Eu sempre começo um projeto o mais 'em branco' possível e permito que muitas decisões sejam determinadas pela praticidade. A realidade é obstinação. Essa é outra maneira de planejar: não é o objetivo inicial que determina a qualidade de um projeto, mas o processo. Como artista, eu não tenho um estilo típico ou obra. Em meus projetos eu trabalho principalmente 'escondido'. Para mim, arte é significado mais do que desfecho. Eu ligo diferentes tipos de especialistas. O projeto é central e nele eu faço uso generoso de experiências e conhecimentos de outros presentes. Mas eu mantenho o controle da direção do projeto." (T.A.)
} 
Ela foi dividida em 11 regiões postais e os participantes de cada área receberiam o mesmo questionário no mesmo dia.

A primeira apresentação pública da obra envolveu a participação de 55 habitantes escolhidos de maneira que o número de integrantes por região postal fosse equilibrado.

As questões apresentadas aos poucos aos participantes foram gradativamente se detalhando, tornando-se cada vez mais pessoais. Eram quatro questões enviadas a cada dia útil ${ }^{16}$ num período de seis meses e totalizando 360 questões. Cada participante tinha de acessar o website do projeto com sua senha e nome de usuário para poder responder a cada uma das quatro questões. Cada questão estava associada a um dos quatro sentimentos e para cada uma o participante escolhia entre cinco alternativas, a saber: muito, sim, um pouco, não, absolutamente não ou nenhuma resposta.

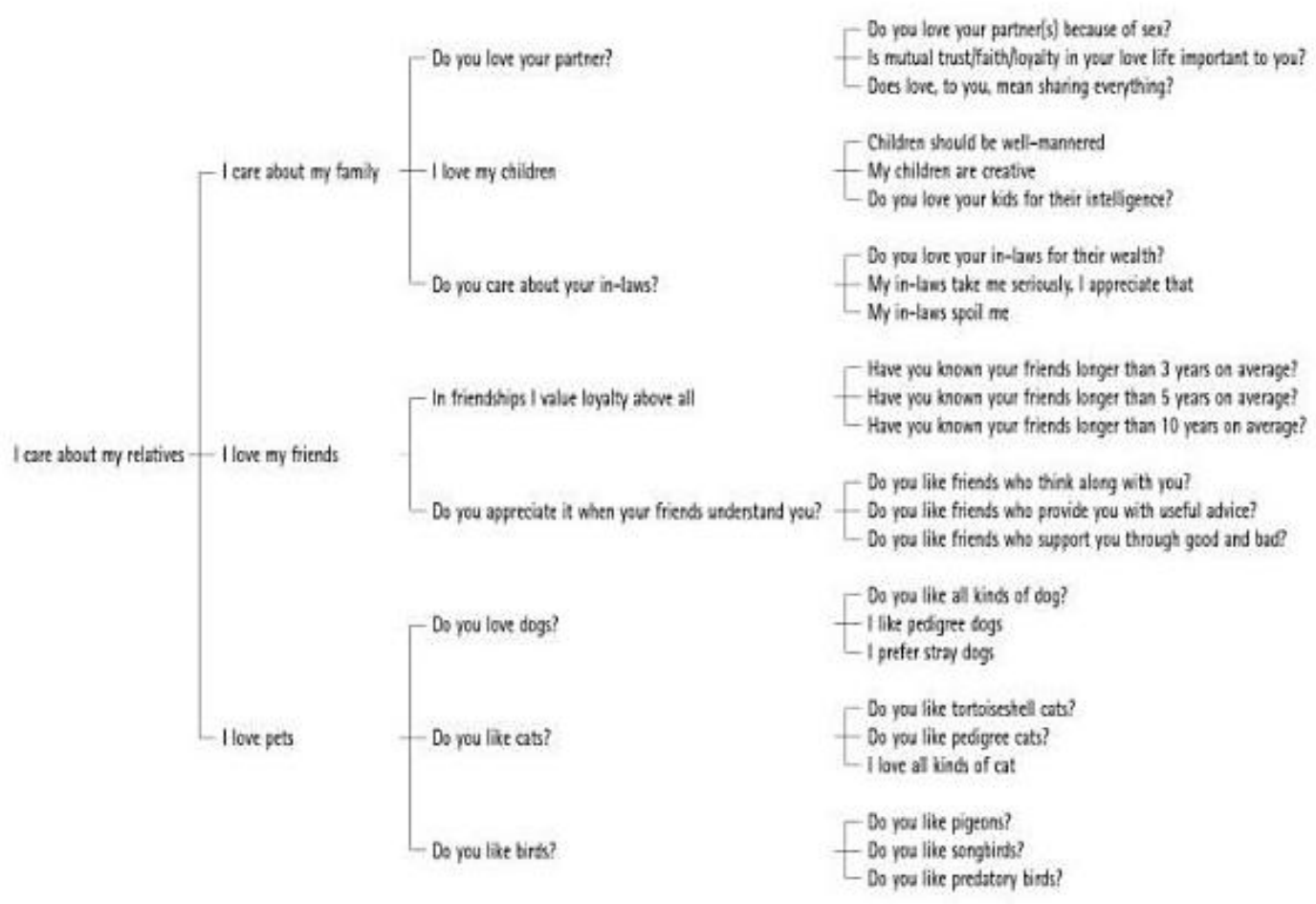

Figura 87: Modelo de algumas questões recebidas pelos participantes.

Fonte: (SERAFIJN, 2005, p.46)

\footnotetext{
${ }^{16}$ Todos os dados numéricos que envolvem o detalhamento da quantidade de perguntas enviadas e os dias em que os participantes receberam as questões se basearam em relato do artista retirado do livro de Brouwer (2005, p.39-47).
} 
Os resultados dos questionários foram então calculados, armazenados em um banco de dados e retransmitidos a um gráfico disponível no website do projeto. Esse gráfico apresentou visualmente, por região postal, o índice de emoções resultante daquele dia, sob a forma de uma "paisagem emocional". Nesse mapa emocional, a média de sentimentos daquele dia, naquela região, é representada por picos e declives em um cenário, sinalizando um índice de felicidade ou tristeza. Esse cálculo da média de pontos atribuídos ao resultado da pesquisa tem início às 17 h00 de cada dia e resulta em um valor que a máquina associa a um dos quatro sentimentos. $\mathrm{O}$ autor exemplifica da seguinte forma: "amor 100 pontos, ódio 33 pontos, felicidade 90 pontos e medo 45 pontos."

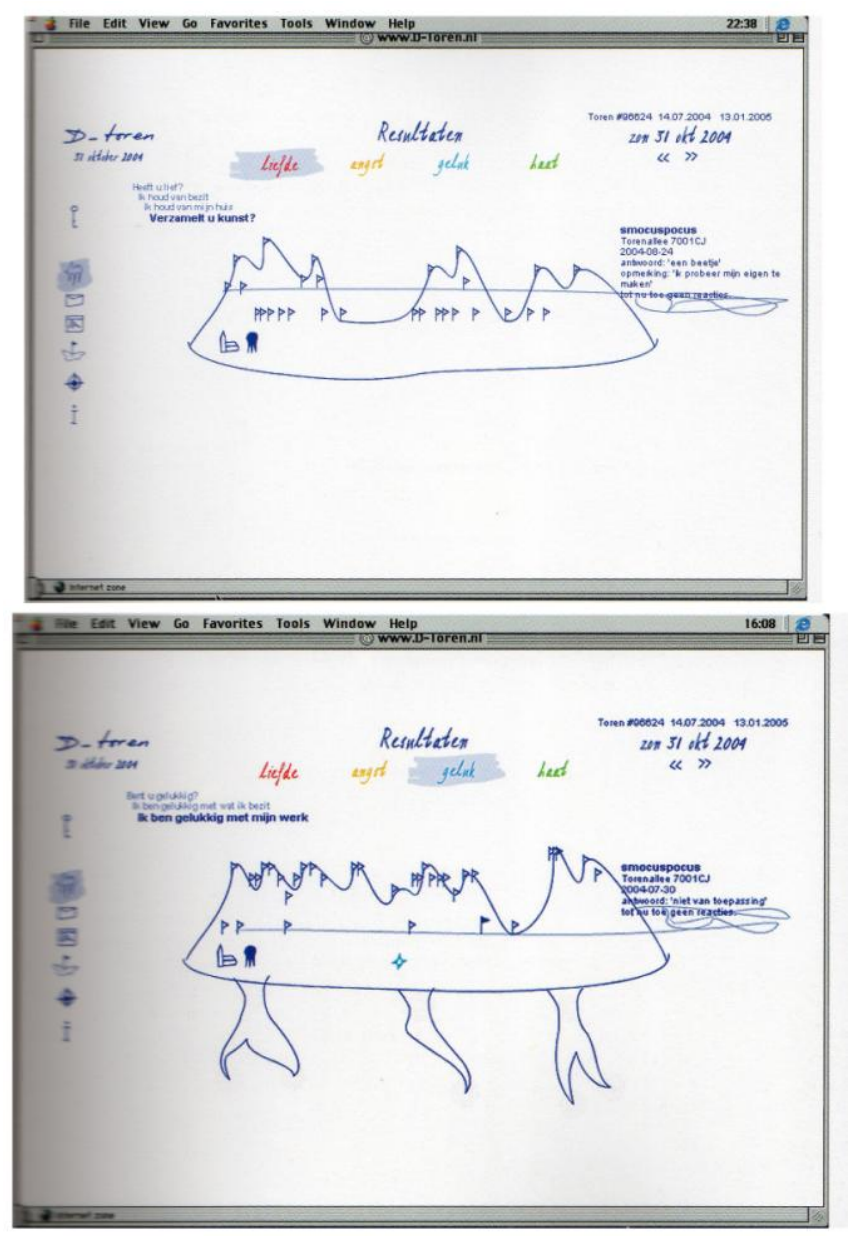

Figura 88: Gráficos emocionais dos sentimentos de amor e felicidade. Fonte: (SERAFIJN, 2005, p.45)

Além do cálculo da média de emoção dos habitantes por região postal, que é apresentada no website do projeto, é também calculada uma média geral com todos os participantes, resultando na emoção coletiva da cidade. E nesse momento o sentimento resultante é traduzido em uma cor. 
A torre então recebe essa média geral, enviada pelo banco de dados, e traduz esse valor em uma cor que é acesa por LEDs, de forma a sinalizar, através de sua estrutura de epóxi, o sentimento coletivo dos habitantes para que toda a cidade possa compartilhar e assim se conhecer.

As cores de fonte luminosas emitidas pela torre associam a cor vermelha com o amor, a cor azul com a felicidade, a cor amarela com o medo e a cor verde com o ódio. A cor como fonte luminosa entra assim na proposta poética, pois para o artista é por meio dela que vai mostrar os sentimentos da maneira mais clara e direta possível. $\mathrm{O}$ artista acrescenta a essa escolha o fato de que trabalhar com a cor de fonte luminosa foi mais acessível financeiramente. Outra vantagem da cor é o fato de ser ela um elemento simples e identificável por qualquer pessoa.

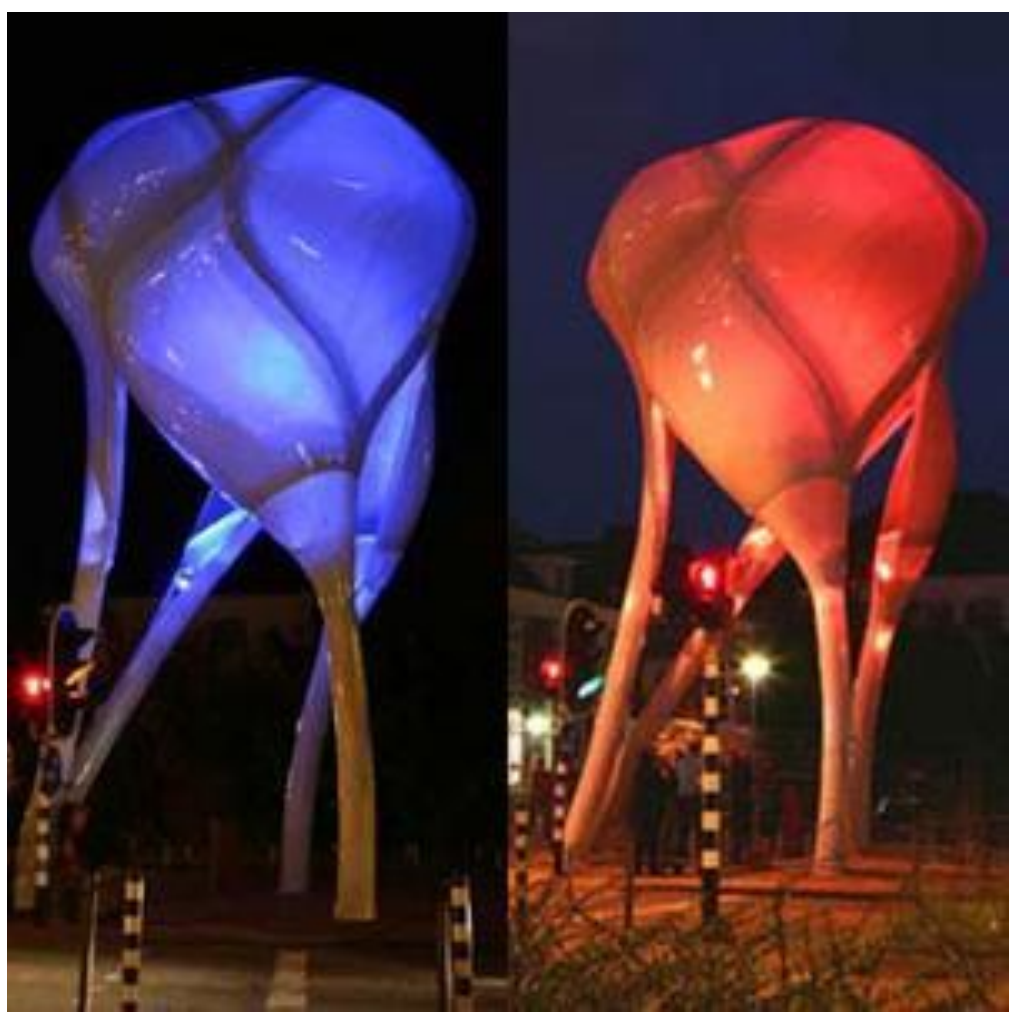

Figura 89: Torre iluminada em azul (felicidade) e vermelho (amor).

Fonte: 〈www.arcspace.com>

O repertório exigido ou praticado pela obra procura abranger o coletivo de uma cidade utilizando uma linguagem que por eles será incorporada e que não exclui nenhum participante. O padrão cromático adotado pelo artista como linguagem possui uma identificação comunicativa com os receptores por expressar os mais básicos sentimentos. Sendo assim a leitura da obra se limita apenas à decifração desse código de 
linguagem, mas a participação ativa dos receptores exigirá, além da decodificação da informação, o conhecimento e a habilidade no manuseio dos dispositivos tecnológicos, como a interface do computador e o acesso à Internet.
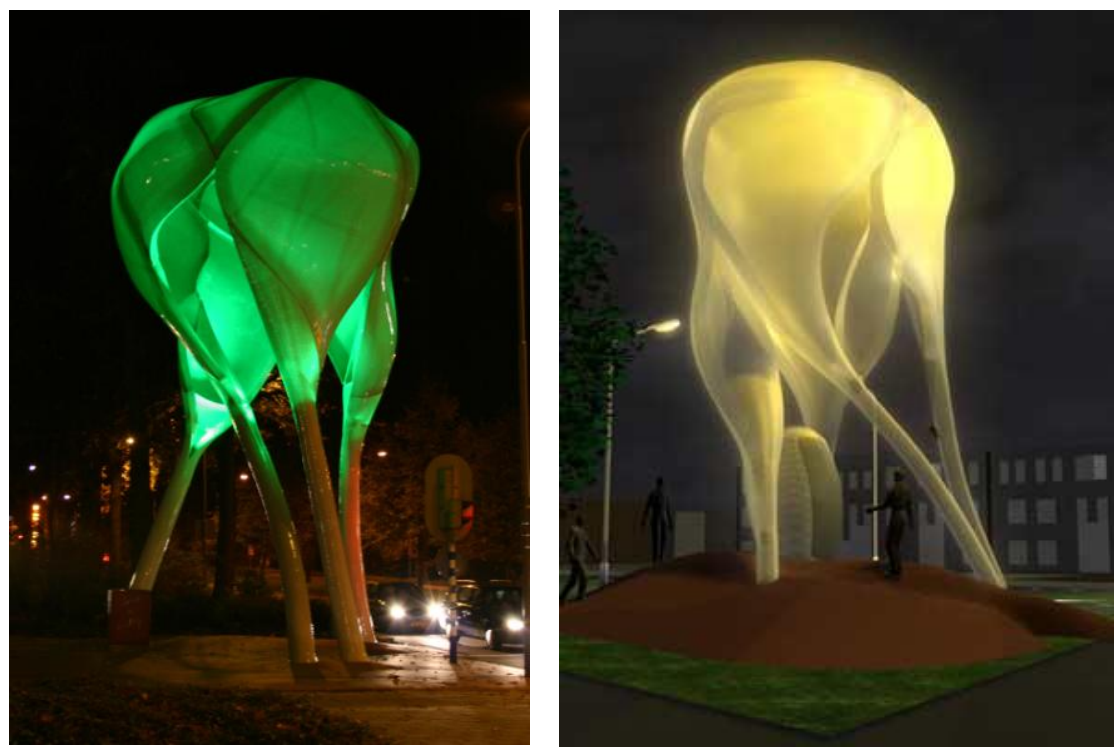

Figura 90: Torre iluminada em verde (ódio) e amarelo (medo).

Fonte:

<www.arcspace.com>

Ao terem influência sobre a obra, os habitantes/participantes do projeto tornam-se, conforme o autor, “coautores”. São as pessoas (participantes), então coprodutores da obra, que têm arbítrio para alterar (em conjunto com os demais) as cores emitidas pela D-Tower e não o artista, cuja função foi única e exclusivamente a de promover esse diálogo entre obra e participantes, numa espécie de "poeta da conexão" (PRADO, 1997, p.297).

No que se refere à escolha das cores, Q.S.Serafijn atribui essa determinação a uma livre associação da informação cromática com sentimentos que partiu de uma escolha dos autores. Ainda de acordo com Serafin, as pessoas, de maneira geral, concordavam com as associações vermelho para amor e azul para felicidade, porém achavam discutível o fato de se associar a cor verde ao ódio e o amarelo ao medo.

Se formos levar em conta o que já foi citado anteriormente nesta pesquisa a respeito da cor verde, veremos que o autor austríaco Jorrit Tornquist (2008, p.263) nos chama a atenção para a conotação negativa dessa cor. De acordo com ele, o verde (em seu sentido negativo) se associa primeiramente ao sentimento de raiva, e exemplifica nos lembrando das seguintes metáforas: "verde de raiva", "verde de inveja" ou simplesmente "ficar verde" como associação a algo ruim. O que poderia ter provocado 
este estranhamento das pessoas em relação ao verde seria então pelo fato de que essa cor, em seu sentido positivo e predominante, se associa ao que é natural. Já o amarelo, que também teria causado controvérsias, segundo Tornquist (2008, p.264), teria no ocidente uma associação negativa. Desde há muitos séculos atrás o amarelo é associado ao que é corrupto, a inveja, a falta de sinceridade e a hostilidade.

Por um outro lado, como é de comum acordo na cultura ocidental, as cores vermelho e azul sempre possuíram uma associação indiscutível com o amor e a felicidade - apesar de o vermelho também conotar sangue e violência. Dessa forma, não causaram estranhamento ao público à primeira vista.

A cor na obra foi utilizada pelo artista com a intenção de representar e unir os sentimentos das diferentes partes da cidade, afetando os moradores e visitantes em uma experiência sensível. A cor como fonte luminosa é utilizada nesta obra como um valor de significação. E por estar há tanto tempo em funcionamento e de uma forma ou de outra afetando a maneira como os cidadãos de Doetinchem lidam com suas emoções, a obra passa a atribuir valores e significação a cada uma das cores, que antes do projeto podiam não significar nada além de uma informação cromática.

A tecnologia utilizada nessa obra ultrapassou as expectativas de se atingir uma cidade inteira e permitiu a articulação de informações e dados em uma complexa rede em que o receptor, em conjunto com outros participantes, interagem e obtêm uma resposta além da visual, significativa da obra e fazendo-os refletir sobre como está a cidade e incentivando os habitantes a se conhecerem melhor. A proposta original do artista, de fazer a cidade se conhecer, foi dessa forma alcançada.

A estratégia de interação proposta pela imagem é feita através da experiência sensível quando o receptor com base em sua opinião pessoal responde ao questionário, ação diretriz essa que é particularizada para cada receptor e que é reunida e traduzida pela torre como uma única média informacional cromática. (parágrafo está repetitivo) 
O uso da cor na obra D-Tower não é aleatória, mas segue critérios controladores e reativos que pressupõem apenas quatro formas de expressão. O sentido da obra só se justifica pelo uso das quatro cores e pelo envolvimento delas com os moradores da cidade. O sentido de reativo que a obra possui se define tanto pelo limite de cores oferecidas como pelo sentido seu ter sido previamente delimitado pelo autor.

Partindo dessa linha de pensamento, de que a obra D-Tower é reativa, podemos então supor que, com base no que foi introduzido sobre os conceitos de interação, esta obra possui um caráter reativo, mas numa tendência ao interativo, promovendo uma retroalimentação dos dados enviados pelo participante e fechando-o num esquema controlado de respostas. Isso é fácil de se notar no questionário, que não aceita uma resposta livre do participante, mas oferece cinco opções de caminhos pré-deternminados que o receptor poderá percorrer para alcançar o resultado da obra. Mesmo assim a DTower é uma obra cuja função não existiria sem a participação em massa dos habitantes. Mesmo possuindo um estreito leque de possibilidades, são os participantes que determinam a cor predominante de cada dia. Eles podem coletivamente alterar o resultado da obra, mesmo estando restringidos a determinadas regras e opções limitadas.

A obra D-Tower, por permitir um acesso coletivo dos habitantes da cidade, constrói uma informação diferente e que envolve o coletivo na obra. A resposta da cidade é um indicador de como os habitantes se sentem e convivem entre si, trocando experiências e vivências inerentes ao seu ambiente cultural. As cores podem afetar as pessoas dessa cidade e também servir como um indicativo aos moradores (participantes ou não) do que poderia nela se melhorar, contribuindo para a resolução de possíveis problemas. Os participantes podem também enviar mensagens, que ficam expostas no website para participantes de outras regiões postais. Um participante pode, por exemplo, enviar mensagens de encorajamento para pessoas que estão situadas em uma região em que predomina o medo, fazendo assim com que ocorra uma ligação não somente entre receptor e obra mas também entre os próprios participantes. A obra acaba por promover um diálogo não apenas entre ela e o receptor, mas entre os participantes, dando a oportunidade desses indivíduos contribuirem para uma melhora no estado de espírito da cidade como um todo. $\mathrm{O}$ artista, ao propor a participação coletiva, contribuiu então para a existência de um pensamento coletivo por parte dos participantes. 
A D-Tower possui em seu interior potentes LEDs capazes de emitir as quatro cores (vermelho, verde, amarelo e azul) através da superfície de epóxi leitoso do qual a concha da torre é formada. O efeito de se iluminar de dentro para fora com essas cores foi, no contexto dessa pesquisa, denominado emissão de luz. E a emissão de luz na superfície da torre delineia sua estrutura, dando forma a ela na escuridão da noite. A torre que emite a luz assume um papel de expositora de uma informação. Como já foi visto no início desta dissertação, sem luz os olhos não trabalham, a escuridão nos deixa à deriva, sem poder identificar nenhum sinal por meio dos nossos órgãos receptores, os bastonetes e os cones. Dessa forma, quando uma luz é percebida em meio à escuridão, ela ou vai derivar de uma fonte natural, como o fogo, ou será de uma fonte artificial, como a luz emitida ou projetada.

A ação da torre ao emitir a cor de "dentro para fora" demonstra também que o sentimento que antes era invisível à comunidade agora é exposto, emitido, irradiando uma informação que saiu da "epiderme" da cidade.

Podemos também concluir que, pelo fato de a obra D-Tower ocupar um local a céu aberto no meio da cidade, a melhor maneira para se comunicar é no período noturno devido à baixa luminosidade natural do ambiente. As luzes emitidas se sobressaem em meio ao caos urbano. No escuro, se destaca como uma estrutura iluminada de 12 metros de altura em contraste com as luzes que não se apagam da cidade, como semáforos, janelas das casas e apartamentos, lojas, etc. A torre se sobressai no ambiente em que melhor ela pode se comunicar e se fazer visível.

Por ser a D-Tower uma estrutura suspensa de cujo interior se emite uma determinada luz colorida, exclui-se o fato de que o participante se sentirá imerso na cor. Ao contrário, o participante que avistar a obra precisará manter uma certa distância para apreciá-la em toda sua magnitude. Pelo fato de a torre possuir doze metros de altura e ser ativada apenas no período noturno, a partir das $20 \mathrm{~h}$, ela precisa ser observada a uma determinada distância.

A experiência sensível que a obra transmite ao participante está associada à mudança no cotidiano da cidade, não sendo algo que o receptor perceba instantaneamente. Trata-se de um efeito prolongado, que se nota diariamente durante o ano. 
O artista não se limitou a sugerir os quatro diferentes significados como resultado da obra. Se vista sob um contexto geral, a obra não se compõe apenas da torre física como projeção de significados incorporados pelos participantes, mas é um conjunto de interligações entre o website, o questionário e a torre. Os resultados obtidos no decorrer do projeto vão ao encontro da sugestão do artista de "ligar diversos pontos" da cidade à medida que os receptores, por meio dos dispositivos, passam a se conectar com outros receptores e a se conhecer, sendo a cor determinante para o alcance desse objetivo. 


\subsection{Breve síntese das propostas dialéticas}

$\mathrm{Na}$ tentativa de apresentar de maneira sucinta as dialéticas inerentes à estrutura organizativa de cada uma das obras anteriormente tratadas, destacaremos a seguir para cada específica dialética, como estas se manifestam no contexto da proposta poética estabelecida pelo artista. Pretende-se com essa síntese auxiliar o leitor a entender a relação entre a cor como fonte luminosa e a participação inerente a cada uma das obras.

\subsection{1. [Aleatório $\mathrm{x}$ Controlado]}

No que concerne à dialética aleatório x controlado, entendemos que as três imagens estudadas privilegiam um tipo de participação em que, como lembra Tavares (2000, p.117), "o receptor tende a escolher e combinar elementos inseridos num esquema predefinido de opções". As interações se desenvolvem com base em estruturas predefinidas, implicando que, quanto maior o número de interações sugeridas pelo artista, maior será o campo de possibilidades a percorrer. No caso da obra Colour by Numbers, as propostas estabelecidas ao receptor são bastante limitadas incorporando-se programaticamente uma forma de participação reativa, apesar de ele possuir programaticamente uma liberdade de associar uma infinidade de combinações cromáticas a serem propagadas pelas janelas da torre. Também no que tange à obra Forest of Light, o receptor atualiza apenas o potencial de escolhas embutido na obra, todavia, neste caso, incorpora-se uma espécie de aleatoriedade programada, caracterizando, outrossim, uma participação reativa, visto que a escolha dos matizes é feita randomicamente pelo algorítmo da obra. Já no que se refere à obra D-Tower, a participação dá-se mais uma vez com base nas reações dos receptores, mas, neste caso, um leque pré-programado e controlado de perguntas e opções de respostas é oferecido, como forma de simular a possibilidade de "diálogo" que se abre aos habitantes da cidade. Cada participante da obra é convidado a agir em razão da aceitação de determinadas regras instituídas pelos artistas; contudo, a obra se configura pelo conjunto das respostas dadas ao questionário previamente estabelecido.

\subsection{2. [Individual $x$ Coletivo]}

No que tange à dialética individual $x$ coletivo, reconhecemos que nas três obras examinadas há uma variação que se estende do tipo de participação individual a uma espécie de participação coletiva. No caso da obra Colour by Numbers, a participação 
assume basicamente um caráter individual. Apenas uma pessoa por vez pode ter acesso à obra. No entanto, a proposta poética do artista permite que esta participação se estenda ao coletivo por meio da ação de cada receptor que, ao atualizar a imagem, permite assim a emissão de cores que se difunde por entre o espaço urbano, possibilitando uma conseqüente fruição. No que concerne à obra Forest of Light, a participação pode se desenvolver tanto individual quanto coletivamente, visto que de maneira individual o participante tem o domínio apenas parcial da obra e quando acessada por mais pessoas, torna-se possível explorar partilhadamente a multiplicidade de projeções coloridas de que a obra dispõe. No caso da obra D-Tower, parte-se do individual para se chegar ao coletivo, visto que cada receptor contribui particularmente com a construção da mensagem. A proposta dos artistas é a de conhecer e expressar as emoções do conjunto dos habitantes da cidade a partir da colaboração conjunta dos membros da comunidade ao responderem e atualizarem os questionários previamente estabelecidos.

\subsection{3. [Projetado $x$ Emitido]}

No que concerne à dialética projetado x emitido, ela revela formas potenciais da cor como fonte luminosa para atingir a recepção. A cor, seja ela projetada ou emitida, assume diferentes formas de expressão a depender do dispositivo de propagação utilizado e definido pelo artista. Normalmente, o dispositivo de interface utilizado para a propagação da cor como luz interfere e condiciona a determinação da proposta poética pretendida pelo artista, atingindo o receptor de maneira mais ou menos sensível. Como lembra Tavares (2000, p. 129), no caso das novas mídias digitais, a rasura do suporte comporta a rasura da mensagem, o que mostra quão importante pode vir a ser o papel desempenhado pelas interfaces físicas na interação entre obra e receptor. No que se refere à obra Colour by Numbers, a cor é materializada pela emissão de luz por meio do uso de LEDs, os quais estão posicionados nas janelas de uma torre. O efeito pretendido é de sinalizar para a cidade uma determinada mensagem estética utilizando a emissão de cor luminosa de um ponto alto do ambiente urbano. A luz é emitida em direção à cidade, assumindo um diálogo sinestésico com o participante e também com os habitantes que lá vivem. No que concerne à obra Forest of Light, as artistas procuraram suscitar pela exploração da projeção de luz colorida na área da floresta percepções diversas nos participantes. A projeção se difunde e se propaga pela floresta, acabando por produzir uma sensação de imersão no ambiente. As cores projetadas à 
frente dos participantes causam, na escuridão, um efeito grandioso que é resultado da poética proposta pelo artista. No que tange à obra D-Tower, a emissão de luz atravessa a superfície da torre iluminando-a e delineando-a. A torre iluminada no período noturno permite que a cor sobressaia interferindo no ambiente da cidade. A torre ao emitir determinadas cores assume a tarefa de trazer à superfície de maneira visível as emoções dos habitantes. De dentro para fora.

\subsection{4. [Informação Estética $x$ Semântica]}

No tocante à dialética informação estética x semântica, percebe-se nas obras estudadas específicas maneiras de utilizar a cor como elemento para atrair a atenção do receptor no intuito de atualizar e reconstruir a poética proposta pelo artista. No caso da obra Colour by Numbers, o papel da cor é "informar", visto que é o elemento que transmite ao coletivo urbano a mensagem poética construída individualmente por cada participante. Apesar deste lidar com códigos diversos na definição da mensagem estética, esta nada mais é do que o resultado das escolhas de cada participante, que por sua vez podem provocar diferentes percepções por parte dos habitantes da cidade. No que se refere à obra Forest of Light, a cor é utilizada predominantemente, com o propósito de produzir sensações, sensibilizando o participante pelo seu efeito visual. A cor como fonte luminosa cativa e captura o receptor ao se diluir no cenário natural, como resultado das ações dos participantes. A forma de articulação da mensagem proposta desvia a atenção do que é simplesmente tecnológico, ressaltando o que é da ordem do natural e a este agregando novos sentidos. No que tange à obra D-Tower, a cor é utilizada no intuito de "informar" diariamente aos habitantes da cidade as emoções por eles vivenciadas. São quatro cores que, associadas cada uma a uma determinada emoção, traduzem os sentimentos dos participantes, provocando esforços interpretativos por parte daquele que frui a obra. Ao contemplar a obra, o fruidor não decodifica a mensagem de acordo com uma única linha de direção. A relação sensível que a torre provoca no receptor é intensificada quando este tem conhecimento de que cada cor nada mais é do que a representação das emoções do conjunto dos participantes. Enfim, para o leitor que tenta interpretar a obra, a torre transmite os sentimentos relativos ao amor, à felicidade, ao medo e ao ódio, nada mais do que representações coletivas dos seus participantes. 


\subsection{5. [Material $x$ (I)Material]}

No que concerne à dialética material x (i)material, são as interfaces utilizadas pelos artistas que se estabelecem como operadoras de contato e de tradução, viabilizando as possibilidades de articulação entre os universos do analógico e do digital. Ao resultar da tradução entre códigos, a cor tratada como fonte luminosa enfatiza o caráter expressivo e sinestésico embutido nas propostas dos artistas. Como se sabe, com base em Tavares (2000, p. 129-130), é a transformação entre imaterial e material, realizada entre os dispositivos transdutores, que garante que a imagem (neste caso, no âmbito da cor como fonte luminosa) se atualize sob diferentes configurações, a partir do trânsito entre softcopy e hardcopy. No que se refere à obra Colour by Numbers, a cor assume um caráter imaterial ao se dissociar dos dispositivos que a geram sendo propagada e interpretada pelo participante como o elemento transmissor de mensagens estéticas. Neste caso, a ação do receptor se dá pelo toque no teclado do celular ou pelo teclado do computador, enviando sinais que serão decodificados e traduzidos em frequência luminosa. Entende-se que a cor seduz pelo efeito a ela inerente e não pelo que é da ordem do tecnológico. No que se refere à obra Forest of Light, as emissões de luz infiltram-se por entre o natural; a ação corporal do receptor ao subir nos troncos aciona o sensor de movimento que associará a presença do participante com uma cor gerada automaticamente por um sistema central da obra. As cores passam a se infiltrar naquele ambiente como se dele fizessem parte explorando diversos sentidos nos participantes. Já no caso da obra D-Tower, a cor como fonte luminosa é tratada poeticamente ao ser associada a sentimentos distintos como: amor, felicidade, medo e ódio. Através dos dados coletados por um questionário, respondidos pelos participantes/moradores, um computador central será responsável por calcular a média das respostas e enviar estes dados para a torre que compreenderá o comando traduzindo-o na cor correspondente, nada mais do que a tradução entre o que é da ordem material e (i)material. 
Em síntese, ao longo deste capítulo e tomando como recorte as obras examinadas, pudemos verificar diferentes maneiras através das quais a cor de fonte luminosa foi utilizada poeticamente pelos artistas de modo a estabelecer um diálogo com o receptor, favorecendo sua participação e seduzindo-o pelo uso dos sentidos. Nestes casos, o receptor atualiza a obra em um processo de retroalimentação, incorporando a ela novos sentidos. Pôde-se constatar que as condições propostas ao interator de modificar a estrutura da obra dependem do nível de abertura que esta propõe, e que por sua vez está também diretamente condicionada ao mecanismo tecnológico associado à proposta poética. Como já vimos, uma obra de caráter reativo se caracteriza por uma limitação na reorganização de dados em comparação com uma obra verdadeiramente interativa. No entanto a proposta poética do artista procura, como vimos nas obras selecionadas, subverter essa limitação tecnológica, promovendo ao participante uma experiência sensível no diálogo com a obra mesmo sendo esta de caráter exógeno.

Como diz Tavares (2000, p.117), retomando a noção de "efeito de liberdade" de Lippmann (com base em Vittadini, 1995:164), para ocultar ou dissimular esta limitação do receptor, simula-se uma liberdade de diálogo, camuflando-se esse limite, seja pelo aumento das possibilidades de combinações relativas às entradas de dados, seja pela possibilidade de trabalhar poeticamente a forma de apresentação das opções de interação.

As obras escolhidas se diferenciam em níveis de participação e na forma em que se apresentam. Porém, elas se aproximam pela sua qualidade poética, pois buscam capturar o receptor e levá-lo à produção de sentidos por meio da utilização da cor como fonte luminosa, fazendo emergir seus efeitos latentes e sensíveis. A exploração da construção de sentidos, significados e significações por meio da cor como fonte luminosa mostrase, quando trabalhada poeticamente, como uma prática bastante rica e crescente na experimentação artística com as mídias digitais. Por ser uma linguagem básica cuja formação se desenvolve associada a sentidos pessoais e culturais, os seus efeitos no homem tendem a ser singulares e sensíveis. 


\section{Conclusao Geral}

De modo a se alcançar os objetivos propostos por esta pesquisa foi necessário conhecer o panorama histórico que lançou bases para o surgimento da cor de fonte luminosa; para tal o capítulo um desta dissertação se dedicou a um resgate das principais contribuições dos estudos e das teorias cromáticas. O capítulo dois trouxe informações que abrangeram o estudo da cor como fenômeno pormenorizando os seus aspectos físicos, fisiológicos, psicológicos e culturais, dados esses essenciais para embasar qualquer estudo na área da cor. Este levantamento sobre as cores culmina na introdução da cor como fonte luminosa, suas propriedades e características. O terceiro capítulo se ocupou da tomada de atenção do espectador, procurando destacar como se deu a sua passagem gradual de fruidor para interator de uma obra. Este panorama da participação cada vez mais ativa do espectador reafirma a noção de obra aberta explicitada na multiplicidade de interpretações e na ambigüidade de significados. Os tipos de abertura e níveis de participação do receptor foram correlacionados cronologicamente destacando uma transformação dos dispositivos que vão do artesanal, do mecânico e do elétrico ao eletrônico e ao digital, e tentando identificar o uso da cor de fonte luminosa nas práticas artísticas. Tendo em vista estes conceitos foi possível com mais clareza e precisão argumentar e examinar no quarto capítulo as três obras que produzidas com base nas NTC utilizam a cor como fonte luminosa e forma de inserir o receptor a partir de uma participação instantânea, se não plenamente interativa, mas de todo modo dada pela reação do participante.

A partir do que expusemos nesta pesquisa, inferimos que a fonte luminosa foi um dado novo, introduzido aos poucos na arte. O seu uso se vê associado a um ímpeto de mudança com um crescente interesse dos artistas em adotar o que havia de mais recente na ciência. Esta tendência, que hoje é corrente entre os artistas da era digital, encontra fundamentação histórica nos estudos que abriram caminho para o desenvolvimento da ciência e da tecnologia. Os dispositivos tecnológicos que decorreram desse desenvolvimento foram acompanhados de perto pelos artistas que procuraram adaptálos, à medida que surgiam, de modo a satisfazer suas propostas poéticas no momento de produção de suas obras. A cor como fonte luminosa foi um dos elementos explorados 
pelos artistas, manifestando-se por meios artificiais e acompanhando, junto com o avanço da tecnologia, novas maneiras de ser articulada e manipulada, tornando-se uma característica marcante nas obras produzidas nas Novas Tecnologias da Comunicação (NTC).

O uso das novas tecnologias eletrônicas instaurou diferentes possibilidades de participação do público na arte. $\mathrm{O}$ artista passa a ter em mãos uma diversidade de novas tecnologias para trabalhar com a luz. Esses procedimentos de geração de imagens abrem diferentes potencialidades de expressão. Nas atuais experimentações digitais, a arte, a ciência e a tecnologia cada vez se imbricam como mecanismo para considerar a atual inserção do interator como via para a metalinguagem e a transgressão dos meios. O uso da cor como fonte luminosa e seu processo de produção estão invariavelmente ligados à relação entre ciência e tecnologia, não sendo possível dissociá-los. Desta forma, o modo de operar poeticamente com os meios digitais revela a transição do uso da cor do objeto para a cor como fonte luminosa. O artista define a cor como elemento mediador do processo, utilizando-a como um elo na comunicação entre a obra e o receptor.

A partir das obras examinadas percebe-se a importância da poética do artista ao subverter as limitações impostas pela tecnologia, conseguindo através dela promover a geração de sentidos. Ao fazer isso, o artista possibilita e cria determinadas estratégias que, ao serem efetivadas pelo receptor no diálogo com a obra, faz recuperar a poética por ele proposta. O participante então recupera os aspectos sensíveis da obra mesmo estando ele dialogando com uma obra de caráter operativo e exógeno.

No entanto, não se pode deixar de lado que a cor procedente de fonte luminosa, ao contrário da cor pigmento, assume uma intensidade muito maior e com isso envolve o receptor de maneira muito mais efetiva. As três leituras feitas no último capítulo procuraram demonstrar isso. Nas propostas poéticas dos artistas, percebemos a importância da informação cromática como elemento intermediador do diálogo com o receptor. Do ponto de vista da interação estas obras permitiram um diálogo com o receptor favorecendo a produção de uma experiência única e sensível. 
Podemos perceber a importância do uso da cor como forma de inserir o receptor ao tomar como pressuposto a presença de informação cromática como elemento dinamizador e atualizador da proposta poética.

Enfim, percebe-se que a depender da poética proposta pelo artista é possível envolver o participante fazendo-o interagir de modo lúdico e descompromissado. A cor neste sentido auxilia nesta soma de envolvimento garantindo, se utilizada conforme a linguagem a ela inerente, potencializar os efeitos propostos pela poética estrategicamente construída. A cor neste sentido acaba por definir o sentido da obra afetando sensivelmente os participantes mesmo estando estes fechados a um diálogo reativo. 


\section{Referências Bibliográficas}

ARAGAKI, S. Agam: beyond the visible. Jerusalem: Gefen Publishing House, 2007.

ARGAN, G. C. Arte moderna. São Paulo: Companhia das Letras, 1992.

ARGAN, G. C. Introdução. In: GOETHE, J. W. La teoria dei colori. Tradução de Luiz Alberto de Genaro. Milano: II Saggiatore, 1999.

BARROS, L. R. M. A cor no processo criativo. São Paulo: Editora Senac São Paulo, 2007.

BATCHELOR, D. (Org.) Colour: documents of contemporary art. Cambridge: The MIT Press, 2008.

BENJAMIN, W. Obras escolhidas: magia e técnica, arte e política. São Paulo: Editora Brasiliense, 1993.

BOUMA, P. J. Physical aspects of colour: an introduction to the scientific study of colour stimuli and colour sensations. Eindhoven: Philips Gloeilampenfabrieken, 1947.

BRIK, O. Photography versus Painting (1926). In: BATCHELOR, D. (Org.). Colour: documents of contemporary art. London: The MIT Press, 2008. p. 89-91.

BROUWER, J. (Org.). Art \& D: research and development in art. Rotterdam: V2_Publishing/NAi Publishers, 2005.

CHERUKU, D. R.; KRISHNA, B. T. Eletronic devices and circuits. New Delhi: Dorling Kindersley, 2008.

COUCHOT, E.; TRAMUS, M.; BRET, M. A segunda interatividade. Em direção a novas práticas artísticas. In: DOMINGUES, D. (Org.) Arte e vida no século XXI: tecnologia, ciência e criatividade. São Paulo: Editora da UNESP, 2003. p.27-38.

COUCHOT, E. A tecnologia na arte: da fotografia à realidade virtual. Porto Alegre: Editora da UFRGS, 2003.

DANGER, E. A cor na comunicação. Rio de Janeiro: Fórum Editora Ltda. 1973.

DEMPSEY, A. Estilos, escolas e movimentos. São Paulo: Cosac Naify, 2003.

DOMINGUES, D. (Org.). A arte no século XXI: a humanização das tecnologias. São Paulo: Editora da UNESP, 1997. 
DOMINGUES, D. (Org.). Arte, ciência e tecnologia: passado, presente e desafios. São Paulo: Editora da UNESP, 2009.

DOMINGUES, D. (Org.) Arte e vida no século XXI: tecnologia, ciência e criatividade. São Paulo: Editora da UNESP, 2003.

DOMINGUES, D. Criação e interatividade na ciberarte. São Paulo: Experimento, 2002

ECO, U. How Culture Conditions the Colours we see. (1985) In: BATCHELOR, D. (Org.). Colour: documents of contemporary art. London: The MIT Press, 2008. p. 178-185.

ECO, U. Obra aberta: forma e indeterminações nas poéticas contemporâneas. São Paulo: Perspectiva, 2005.

FARINA, M. Psicodinâmica das cores em comunicação. São Paulo: Edgard Blücher, 2006.

FERREIRA, J. P. Os trabalhos da luz. São Paulo: Fundação Memorial da América Latina, 2006.

FRASER, T; BANKS, A. O guia completo da cor. São Paulo: Editora Senac São Paulo, 2007.

FRIELING, R. (Org.) The art of participation: 1950 to now. San Francisco: Thames \& Hudson Inc., 2008.

GAGE, J. W. Color and meaning: art, science, and symbolism. Los Angeles: University of California Press, 1999.

GOETHE, J. W. La teoria dei colori, introdução. Tradução de Luiz Alberto de Genaro. Milano: II Saggiatore, 1999.

GROYS, B. A genealogy of participatory art. In: FRIELING, R. (Org.). The art of participation: 1950 to now. San Francisco: Thames \& Hudson Inc., 2008. p.19-31. GUIMARÃES, L. A cor como informação: a construção biofísica, linguiística e cultural da simbologia das cores. São Paulo: Annablume, 2000.

GUIMARÃES, L. As cores na mídia: a organização da cor-informação no jornalismo. São Paulo: Annablume, 2003.

LICHTENSTEIN, J. A pintura: textos essenciais. São Paulo: Editora 34, 2006. 9v. 
LIESTØL, G; MORRISON, A; RASMUSSEN, T. (Org.) Digital media revisited: theoretical and conceptual innovation in digital domains. Cambridge: The MIT Press, 2003.

MACHADO, A. Hipermídia: o labirinto como metáfora. In: DOMINGUES, D. (Org.). A arte no século XXI: a humanização das tecnologias. São Paulo: Editora da UNESP, 1997. p. 144-154.

MALINA, R. Leonardo olhando para a frente: Fazendo a história e escrevendo a história. In: DOMINGUES, D. (Org.). Arte, ciência e tecnologia: passado, presente e desafios. São Paulo: Editora UNESP, 2009. p.15-20.

MCLUHAN, M. Os meios de comunicação como extensões do homem: understanding media. São Paulo: Editora Cultrix, 1974.

MORIOKA, A.; STONE, T. Color design workbook. Gloucester: Rockport Publishers, 2006.

OSÓRIO, L. Abraham Palatnik. São Paulo: Cosac Naify, 2004.

PEDROSA, I. Da cor à cor inexistente. Rio de Janeiro: Senac Nacional, 2009.

PEDROSA, I. O universo da cor. Rio de Janeiro: Senac Nacional, 2008.

PLAZA, J; TAVARES, M. Processos criativos com os meios eletrônicos: poéticas digitais. São Paulo: Editora Hucitec Ltda, 1998.

PLAZA, J. Videografia em videotexto. São Paulo: Editora Hucitec, 1986.

POISSANT, L. A passagem do material para a interface. In: DOMINGUES, D. (Org.). Arte, ciência e tecnologia: passado, presente e desafios. São Paulo: Editora da UNESP, 2009. p. 71-90.

POPPER, F. Art of the eletronic age. London: Thames and Hudson ltd., 1993.

POPPER, F. From technological to virtual art. Cambridge: The MIT Press, 2007.

POPPER, F. Origins and development of kinetic art. London: Studio Vista, 1968.

PRADO, G. Dispositivos interativos em redes telemáticas. In: DOMINGUES, D. (Org.). A arte no século XXI: a humanização das tecnologias. São Paulo: Editora da UNESP, 1997. p. 295-302. 
QVORTRUP, L. Digital poetics. In: LIESTØL, G; MORRISON, A; RASMUSSEN, T. Digital media revisited: theoretical and conceptual innovation in digital domains. Cambridge: The MIT Press, 2003.

SALVETTI, A. R. A história da luz. São Paulo: Editora Livraria da Física, 2008.

SANTAELLA, L. A percepção: uma teoria semiótica. São Paulo: Experimento, 1993.

SCHAPIRO, M. S. Impressionismo: reflexões e percepções. São Paulo: Cosac Naify, 2002 .

SERAFIJN, Q. S. D-Tower. In: BROUWER, J. (Org.). Art \& D: research and development in art. Rotterdam: V2_Publishing/NAi Publishers, 2005. p.38-47.

SHUR, M. Introduction to electronic devices. [Charlottesville]: John Wiley \& Sons.Inc, 1996.

SIMPSON, R. S. Lighting control: technology and applications. Oxford: Focal Press, 2003.

SPUYBROEK, L. Nox: machining architecture. London: Thames \& Hudson Ltda. 2004.

TORNQUIST, J. Color y luz: teoría e práctica. Barcelona: Editorial Gustavo Gili, 2008.

TRAVIS, D. Effective color displays: theory and practice. [S.1.]: Academic Press, 1991.

VALBERG, A. Light vision color. Chichester: John Wiley \& Sons Ltda, 2005.

WEIBEL, P. É proibido não tocar: algumas observações sobre (partes esquecidas da) história da interatividade e da virtualidade. In: DOMINGUES, D. (Org.). Arte, ciência e tecnologia: passado, presente e desafios. São Paulo: Editora da UNESP, 2009. p. 91109.

WITTGENSTEIN, L. Anotações sobre as cores. Campinas: Editora da Unicamp, 2009. 
Teses

PERISSINOTTO, P. O cinetismo interativo nas artes plásticas: um trajeto para a arte tecnológica. São Paulo: ECA - Escola de Comunicação e Artes, 2000. Dissertação (Mestrado em Artes), ECA-USP.

SANTOS, P. O. C. Donald Judd: cor, interação entre matéria e luz. Rio de Janeiro: Pontifícia Universidade Católica do Rio de Janeiro, 2005. Dissertação (Mestrado em História Social da Cultura), PUC-RJ.

SILVEIRA, L. M. A reprodução cromática em síntese de imagens: um estudo comparativo à pintura. Campinas: Universidade Estadual de Campinas, 1994. Dissertação (Mestrado em Multimeios), IA-UNICAMP.

SILVEIRA, L. M. A percepção da cor na imagem fotográfica em preto-e-branco. São Paulo: Pontifícia Universidade Católica de São Paulo, 2002. Tese (Doutorado em Comunicação e Semiótica), PUC-SP.

TAVARES, M. S. A recepção no contexto das poéticas interativas. São Paulo: ECA - Escola de Comunicação e Artes, 2000. Tese (Doutorado em Artes Visuais), ECAUSP. 
Artigos:

BYDLER, C. Claiming spaces. Texto disponível em <www.colourbynumbers.org>

CRARY, J. Techniques of the observer. October, Vol.. 45. (Summer, 1988), p.3-35).

GUICCIARDINI, N. Newton. Scientific American, São Paulo, Editora Duetto, p.4-28, 2005. Edição Gênios da Ciência.

PLAZA, J. Análise da pintura Guernica, 1991.

PLAZA, J. Arte e interatividade: autor-obra-recepção. ARS, ano 1, 2003.

POPPER, F. De la participation à l'interactivité dans les arts plastiques. Vers une Culture de l'Interactivité? Actes du Colloque. Cité des Sciences et de l'Industrie La Villette. Paris, 1988, p.89-96.

ROMERO, L. P. La desaparición de los espectadores. Arte y Parte, nº 75, 2008.

TAVARES, M. Fundamentos estéticos da arte aberta à recepção. ARS, ano 1, 2003.

TAVARES, M. Por uma tipologia da imagem interativa. Texto apresentado no $11^{\circ}$ Encontro Anual da Associação Nacional dos Programas de Pós-Graduação em Comunicação. COMPÓS, 2002. 


\section{ANEXO 1. Questões e diálogos trocados com os artistas}

\section{A. Questões Apresentadas aos artistas responsáveis por cada obra}

\section{RELATIVO À POÉTICA PROPOSTA:}

- Qual a proposta poética concernente à obra ? Qual o percurso criativo a ela inerente? Como os meios utilizados foram determinantes na obtenção do resultado alcançado?

- A cor como fonte luminosa foi determinante para a definição da proposta poética? O seu uso foi intencionalmente pensado como forma de potencializar o diálogo com o receptor?

- Qual o papel do receptor na definição da proposta poética?

- No que altera o fato de a obra ser acessada por um grande público em um cenário exterior ao ambiente da galeria ou museu? Esse fato interferiu no processo criativo da obra? Você teve autonomia para escolher o espaço e porque o escolheu? Como é visto o processo de socialização da arte?

- A poética da obra foi pensada apenas por você, ou outras pessoas estiveram envolvidas na criação? Qual a importância de cada uma no processo criativo? 


\section{RELATIVO AO DESENVOLVIMENTO E EXECUÇÃO DA OBRA:}

- Como as mídias digitais influenciaram a definição da proposta poética?

- Em algum momento a poética proposta se alterou em função de dificuldades na execução da obra? Isso afetou o modo de se trabalhar a cor?

- No momento da execução da obra você participou ativamente do processo ou repassou essa tarefa para terceiros executarem? Qual a importância deles no conjunto da obra?

\section{RELATIVO AO USO DA COR PROVENIENTE DE FONTE LUMINOSA COMO LINGUAGEM:}

- Você vê no uso da cor por meio de fonte luminosa uma linguagem mais perceptiva e sensorial do que no uso do pigmento? O que o uso da luz como fonte colorida agrega de positivo na obra que o pigmento não permite (além do uso de novas tecnologias)?

- Como você vê o uso da cor em seu trabalho, foi fruto de uma intenção pré-estabelecida trabalhar com determinada cor ou o seu uso foi definido em função do papel que desempenharia como comunicadora entre obra e receptor? 
B. Resposta enviada pelos artistas Erik Krikortz, Loove Broms e Milo Lavén a respeito da obra Colour by Numbers

\section{CONCERNING THE POETICAL PROPOSAL:}

What is the poetical proposal concerning the artwork Colour by Numbers? What is the creative path inherent to it? How were the means used determining to obtain the results achieved?

The main concern when making Colour by Numbers was to discuss questions about public space.

The cityscapes of today are dominated by commercial interests, and the public space is continually being privatized. Colour by Numbers allowed any person to playfully participate in the shaping of the public space.

The tower encourages Stockholm's citizens to communicate by changing its colours and offers an opportunity for self-representation in the city.

Was the color as a light source crucial to define the poetical proposal? Was its use intentionally designed as a way to enhance the dialogue with the receiver?

By using coloured light it is possible to make big installations comparatively cheap. It is possible to use existing structures and put a focus on them. It is possible to change the appearance of an architectural landmark and through that reach out to a big audience. The installation was definitely designed to encourage a dialogue between the citizens of Stockholm.

What is the receiver's role in defining the poetical proposal?

For Colour by Numbers it might be more adequat to talk about "participant" instead of "receiver", since the art project builds on participation. Without people participating, and actively taking part in the creation of the artwork, there would be nothing.

What we created in the project was less a "proposal", and more a platform for communication. 
What changes are caused by the fact that the artwork will be accessed by a large audience in a setting outside the environment of the gallery or the museum? Did this fact interfere with the creative process of the artwork? Did you have the autonomy to choose the place and to think over this choice? How is the process of art socialization seen?

We choose to work outside the "white cube" in order to intertwine with the stream of quotidian life. Art has a much greater potential when integrated in society.

For Colour by Numbers, Ericsson's former research tower was carefully selected, not only because of its history, but also due to its location in a suburb that was about to get redefiened. There was room for negociation. Perhaps Colour by Numbers could involve more people in thinking about, and taking part in, the creation of this "new" suburb.

Colour by Numbers puts the spotlight on the suburb, and symbolically reverses the structure of communication (the periphery becomes the center).

Was the poetic proposal of the artwork conceived alone or were there other people (from different areas) involved? If there were other people, how important was each one of them in the creative process of developing the project?

We developed Colour by Numbers together as a group of three people. Other people and companies involved in the production had little influence on the creative and artistic process of project.

CONCERNING THE DEVELOPMENT AND EXECUTION OF THE ARTWORK:

How did the digital media influence the definition of the poetic proposal?

Digital media is more and more integrated into society as material just as any other. As we know, digital media is so much more than just a screen - if you by screen mean the traditional computer or television screen. For us, the cityscape has become the screen and our everyday artefacts can become the tools for interacting with it - like in this case, the relationship between the mobile phone and the tower. 
Was there any change in the poetic proposal because of any difficulty during the execution of the artwork? Did that affect the way you were working with the color?

Of course you are very much affected by the materials and tools that you use to create something but in this project we did not run into any major difficulties that forced us to alter our initial idea in any major way.

While the artwork was being executed, did you actively participate in the execution or did you pass it over to other people? What is these people's importance in the whole work?

We all actively participated in the execution of the project on all levels but also with assistance of other people. For such a large project it would have been troublesome to do it all by ourselves, and together with the help of specialists in, for example, lighting and electronics we could achieve the result we wanted much quicker. Of course, interacting with these people influenced us, but not in a way that it would have changed the idea in any dramatic way if we would have decided to hire different people.

CONCERNING THE USE OF COLOR FROM LIGHT SOURCE AS A LANGUAGE:

Do you think using color by a light source is a way of getting to a more perceptive and sensorial language than using color from pigment? What positive aspects does the use of light as a colorful source aggregate to the artwork and the pigment does not (besides using new technologies)?

Well, yes... You can see light from much further away, and when it is dark outside (which is very powerful). At the same time, with the introduction of new lighting technology, this form of expressions is used much more extensively in a, what we consider, much more superficial way.

What do you think about the use of color in your work? Did it result from a predetermined intention to work with any certain color or was its use conducted by the communicative role it would perform between artwork and receiver?

We did not have any intention to work with any specific colour. For us it was a platform for interaction and communication. 
C. Diálogos com a artista Christina Okai Mejborn (TotemCollective), a respeito da obra "Forest of Light"

Juliana H. Henno |08/07/2010

[...] I would like to get more information on how the colors were used to display the interaction with the audience. What was the mechanism behind, how people could interact to change the colors?[...]

Christina Okai Mejborn | 08/07/2010

[...] We used 20 GLP impression lamps on a forest area of approximately $50 \mathrm{~m} x$ $50 \mathrm{~m}$. These lamps are normally used for concerts [...]. We made an installation in front of the forest on which we placed a camera on the top. The camera was set to react whenever it registered a difference of movement on a tree trunk underneath it. Each tree trunk was connected to a specific lamp - thereby people could control which lamps to light up. The colors changed randomly. [...]

Juliana H. Henno | 09/07/2010

[...] when the participant is on the top of the trunk does the camera identifies only his presence over that trunk activating one determined light or the camera can identify besides his presence various positions of the participant over the trunk changing the colors light intensity and saturation? If my second supposition is right, then the camera controls the levels of brightness and saturation of colors that will randomly be project upon the trees? [...]

\section{Christina Okai Mejborn | 14/07/2010}

[...] Both of your suppositions are right. The illustration from the pdf was our initial intention for the project, where we wanted the participant to be able to change light intensity and color, thus exploring the qualities of LED lights. When it came to the actual installation, we decided to simplify the interaction between participant and light by letting the computer change colors randomly. This way 
the camera only registered the presence of a person on a specific trunk, which was a command control for putting on a specific light. [...]

Juliana H. Henno | 16/07/2010

[...] This decision about simplifying the process came due to a lack of time in reason of the complexity technology or it was a poetic decision? [...]

Christina Okai Mejborn | 28/07/2010

[...] Our decision about simplifying the interaction features was based on the fact that it is crucial for an interactive installation to have an "intuitive output" for its recipients. That is, if the interaction is too complicated, the recipient (or user) may not perceive the feedback between his actions (moving around on the tree trunks) and the commands given to the LED lights. Example given: If I jump from tree trunk to tree trunk and this causes the light to be lit according to which tree trunk I'm standing on, I will quickly get the point of the output of my actions. If on the other hand my jumping around lights up the LEDs /and/ changes the colors and intensity of light, it would take longer to figure out the logic of the installation.

A more concrete example is a washing machine that is filled with many configurations and buttons. Most people just want to wash their clothes at a certain temperature, so they'll just stick to the simplest feature of washing at " $X$ " degrees and never use the other potential functions, that demands to look in a user manual. [...] 
D. Resposta enviada pelo artista Q.S. Serafijn a respeito da obra D-Tower

CONCERNING THE POETICAL PROPOSAL:

What is the poetical proposal concerning the artwork D-Tower? What is the creative path inherent to it? How were the means used determining to obtain the results achieved?

1998: The city of Doetinchem already had a plan consisting of 4 sculptures (fire, water, earth, sky), they were called 'towers', in places where there were citygates in the past.

I was the first artist they invited to design the first tower ('fire')

I proposed a tower that was interactive and reflected something of the activities of the city, the inhabitants etc. As I'm not used to building towers (I have never made my work myself, I'm a so-called 'conceptual artist') they allowed me to invite an architect. I thought Lars Spuybroek (NOX) was the most interesting architect for the situation, and he accepted my offer.

Together we developed the idea of a tower that would reflect the inhabitants' emotions. So, reflecting the inhabitants' emotions was the most interesting and intriguing part to us. As if it were, the beating heart of the community.

The problem, however, was: how could we measure the inhabitants' emotions? (We decided to design a questionnaire.) And how could we show the outcome as clearly and as directly as possible? (We decided to use colored light.)

Was the color as a light source crucial to define the poetical proposal? Was its use intentionally designed as a way to enhance the dialogue with the receiver?

Out of this emotionconcept we developed the use of color (or colored light). It might also have been sound, for example, or statistics, or projected video images, but we decided on color, because of the limited budget too. :-

And it had to be simple. No subtle, changing colors, but clear, one-dimensional colors, one for each emotion. 
What is the receiver's role in defining the poetical proposal?

The receiver is the co-producer. If an inhabitant of the city of Doetinchem subscribes as a participant in the project, he or she is - together with the other participants responsible for the color of the tower at the end of the day. And for the 'wellness' of the city...

What changes are caused by the fact that the artwork will be accessed by a large audience in a setting outside the environment of the gallery or the museum? Did this fact interfere with the creative process of the artwork? Did you have the autonomy to choose the place and to think over this choice? How is the process of art socialization seen?

I never work in a gallery. I just make artworks in public spaces and I write books. The spot was selected in co-operation with the city, the commissioners.

If you work in a public space you always have to deal with the public, of course. But I am the expert, I am the experienced artist... I'm not that kind of artist that asks the public to participate in the design of my projects.

I like to work outside the white cube because I like to 'puzzle'. Do you know what I mean? I like to deal with reality, with the impossibilities of the outside world, the architecture, the traffic, the passer-by, possible demolition etc. It's the real world I'm working in. (Dreaming is for my books...)

Was the poetic proposal of the artwork conceived alone or were there other people (from different areas) involved? If there were other people, how important was each one of them in the creative process of developing the project?

The architect, of course. And there was this V2, Institute for the Unstable Media, that developed the software part of the website and the connection among the website, the inhabitants, the tower and its lights. This website is the soul of the project. And it's also hidden like a soul. The tower is the body. The inhabitants are the heart...

For more information: http://www.v2.nl/

They are great and I think a very interesting place for you! 
CONCERNING THE DEVELOPMENT AND EXECUTION OF THE ARTWORK:

How did the digital media influence the definition of the poetic proposal?

D-tower is a machine, it works completely by itself. The digital media is the structure of the machine, its veins, blood vessels, cells, protein etc.

The only thing that has to be done by humans is to find people that want to participate in the project during six months. (Every six months a new group of inhabitants participate in the project by answering the 'emotional questions'.)

But at the moment we're designing a digitized 'skin' around the existing project to get this acquisition done by the machine itself as well...

Was there any change in the poetic proposal because of any difficulty during the execution of the artwork? Did that affect the way you were working with the color?

Yes, there have been changes but they didn't influence the use of colored light.

While the artwork was being executed, did you actively participate in the execution or did you pass it over to other people? What is these people's importance in the whole work?

I passed the execution over to other people as I wrote before: the tower, the light and the digital framework. These people are very important, of course. They are, as to say, my 'material'. To be handled with care! Communication, clear communication is the keyword in this kind of processes and projects.

But the questionnaire was completely made by myself. It even has a composition although nobody does notice this because an overview on the questions is invisible. 
CONCERNING THE USE OF COLOR FROM LIGHT SOURCE AS A LANGUAGE:

Do you think using color by a light source is a way of getting to a more perceptive and sensorial language than using color from pigment? What positive aspects does the use of light as a colorful source aggregate to the artwork and the pigment does not (besides using new technologies)?

I don't know. The whole world is using light as messages, it's just an urban way of painting, of giving reality its identity. Light is extrovert, pigment is introvert.

What do you think about the use of color in your work? Did it result from a predetermined intention to work with any certain color or was its use conducted by the communicative role it would perform between artwork and receiver?

I think the last idea. I really don't understand anything of color. For me color is the most incomprehensible element to deal with in art and in reality. 


\section{ANEXO 2. Dispositivos de interatividade que manipulam as fontes luminosas coloridas}

O avanço que se nota neste século em relação aos dispositivos tecnológicos é altíssimo. No âmbito desta pesquisa a preocupação principal foi não deixar de lado os principais equipamentos que permitem a execução de obras cuja base é a interatividade nos meios digitais. Dessa forma, correu-se o risco de deixar de lado alguma tecnologia nova que poderia agregar qualidade ao conjunto de equipamentos aqui abordados.

No cenário da arte e das novas tecnologias, pudemos perceber uma escalada progressiva dos equipamentos tecnológicos desde a metade do século passado. Os artistas de cada época souberam tirar o máximo proveito dos equipamentos recém-lançados em prol de suas propostas artísticas, buscando nesses dispositivos novas possibilidades de interação.

"O princípio que rege a interatividade é o da mutabilidade, da efemeridade, do vir-a-ser em processos que demandam a reciprocidade, a colaboração, a partilha para aquele que se constitui o espectador nas manifestações artísticas anteriores. A arte interativa implica reorganização profunda da sensibilidade, ampliando o campo de percepção em trocas e modos de circulação que exploram os recursos computacionais como a linguagem própria e que transcendem a arte da pura aparência." (DOMINGUES, 2002, p.64)

Para Machado (1997, p.144), a interatividade é "a possibilidade de responder ao e de dialogar com o sistema de expressão." Nota-se que cada vez mais os novos equipamentos propiciam uma "imaterialidade", como se esvanecessem as barreiras que nos separa da obra, fazendo o receptor se sentir imerso durante seu diálogo e sua experimentação com a obra.

Aliados aos dispositivos comuns como o mouse e o teclado, temos hoje em dia equipamentos mais sofisticados de interface sensório-motoras. Entre os dispositivos que compõem a base do referencial prático desta pesquisa e que trabalham com a emissão de luz, selecionamos os seguintes equipamentos em ordem cronológica de aparição: 


\section{Lâmpadas Eletroluminescentes}

A eletroluminescência ${ }^{17}$ se manifesta, de acordo com Simpson (2003, p.151), de duas maneiras diferentes: diodos emissores de luz (LED) e um campo elétrico que estimula uma camada de fósforo.

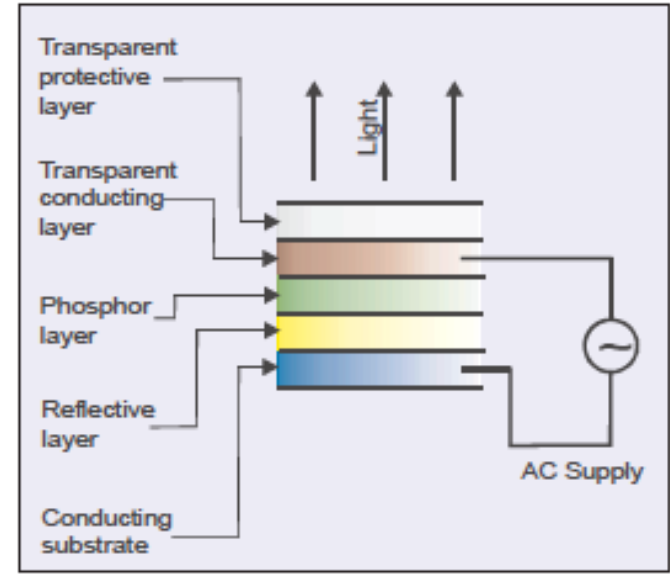

Figura 91: Gráfico esquemático dos princípios de uma lâmpada eletroluminescente. Fonte: (SIMPSON, 2003, p.152)

A lâmpada eletroluminescente plástica é produzida em forma de folha ou rolo contínuo. Quando é feita em forma de folhas ela pode, conforme Simpson (2003, p.152), ser cortada em formatos especiais. Já na forma de rolo é possível se alcançar um comprimento contínuo de $152 \mathrm{~m}$ ou mais. Essas fontes de luzes contínuas são usadas ambas para efeitos especiais, rotas de saídas, degraus de escada, etc.

Quanto maior a voltagem das lâmpadas eletroluminescentes e maior a freqüência, mais brilhante será a luz produzida. Por outro lado, conforme ressalta Simpson (2003, p.152), quanto maior a frequência da lâmpada menor será sua vida útil. Outro fator que também pode comprometer a durabilidade dessas lâmpadas é a deterioração do fósforo, fato esse que, segundo o autor, pode ocorrer na presença de impurezas, principalmente o vapor de água. Normalmente a duração desse tipo de lâmpada pode variar de mil horas a dez mil horas ou mais.

\footnotetext{
17 Localizar definição dicionário. A Eletroluminescência (EL) é um fenómeno óptico e elétrico durante o qual um material emite luz em resposta a uma corrente elétrica que o atravessa, ou a um forte campo elétrico. Deve distinguir-se a emissão de luz por causa da temperatura (incandescência) e por causa da ação de produtos químicos (quimiluminescência). (Wikipedia)
} 


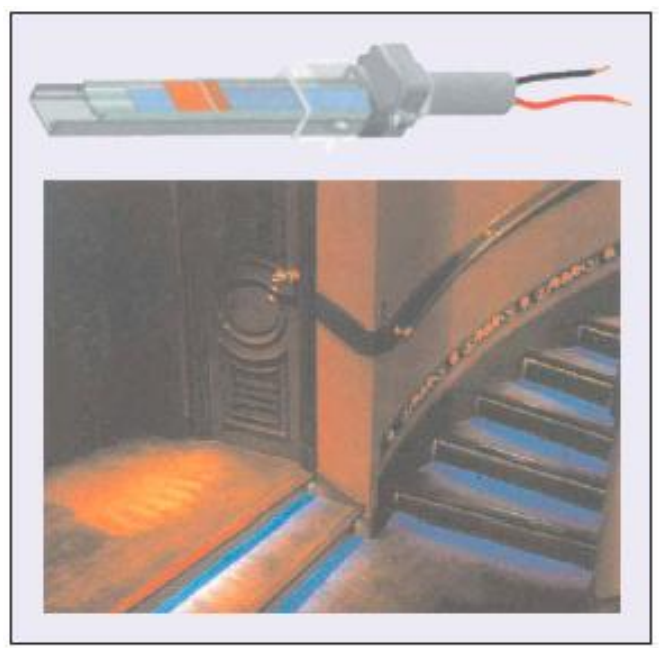

Figura 92: Modelo de lâmpada eletroluminescente em forma de rolo extrudada utilizada para marcar os degraus de uma escadaria. Fonte: (SIMPSON, 2003, p.152)

A gama de cores das lâmpadas eletroluminescentes é limitada. As lâmpadas mais eficientes, são, segundo nos descreve Simpson (2003, p.152), as que produzem luz azul esverdeado, mas também são produzidas as de cores azul, amarelo esverdeado, laranja, branca e vermelha. As lâmpadas eletroluminescentes não são dispositivos de alta luminosidade, seu valor está em sua espessura fina e adequada assim para usos em que outras fontes mais convencionais não se adequam. As lâmpadas eletroluminescentes em formato de folha podem medir, segundo nos confirma o autor, apenas $1 \mathrm{~mm}$ de espessura e em alguns casos até menos.

O princípio das lâmpadas eletroluminescentes se aplica também a outras possibilidades, assim como o fio eletroluminescente. Este fio é basicamente um fio de cobre envolto por uma camada de fósforo. Quando o fio de eletrodo é espiralado, este, conforme nos conta Simpson (2003, p.153), é coberto por fósforo e o conjunto é envolto em uma cobertura plástica resistente. O resultado disso, um cabo luminoso, possui efeitos decorativos mas com uma vida útil bastante curta de menos de mil horas.

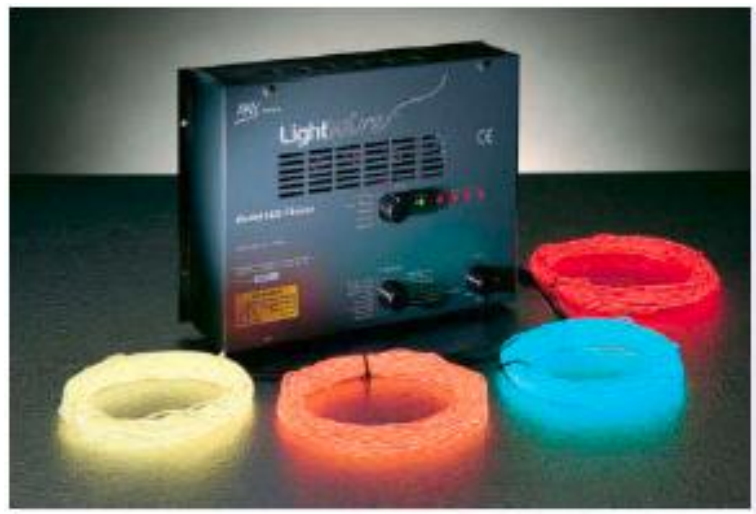

Figura 93: Cabos eletroluminescentes.

Fonte: (SIMPSON, 2003, p.153) 
O princípio da eletroluminescência é, segundo ressalta Simpson (2003, p.153), usado em displays ACTFEL (AC Thin Film ElectroLuminescent). Neste caso a camada de fósforo é aplicada como um fino filme ao invés de pó. O fósforo e os eletrodos são organizados em colunas para permitir a resolução em pixels. O dispositivo resultante é um display robusto e de alta qualidade que compete com o LCD para algumas aplicações.

\section{LED (Diodo Emissor de Luz)}

São diodos emissores de luz. De acordo com Boylestad e Nashelsky (2004, p.631), os LEDs são dispositivos semicondutores que emitem luz em uma determinada intensidade pela corrente direta através do dispositivo.

De acordo com Cheruku e Krishna (2008, p.85), o nome desse dispositivo já indica a sua função, é um diodo que emite luz cuja intensidade é proporcional à corrente elétrica que passa através do diodo. O fenômeno de emissão de luz é chamado de eletroluminescente, e conforme os autores exemplificam, o LED é um transdutor que converte variações elétricas em variações de intensidade luminosa.

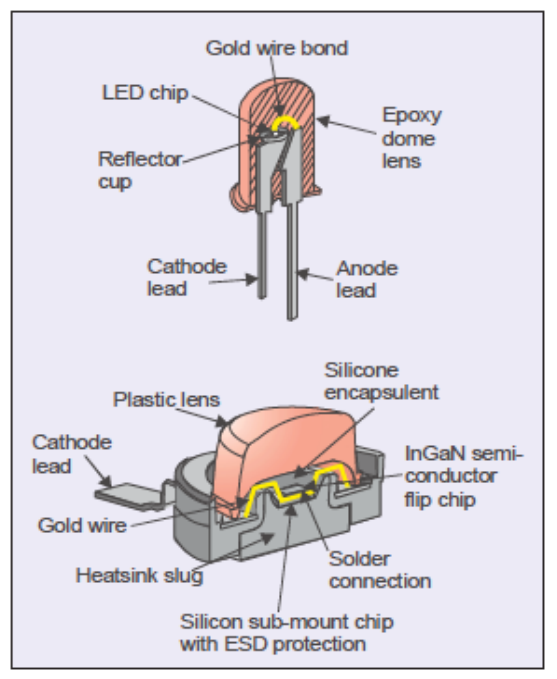

Figura 94: Diagrama com a composição do LED.

Fonte: (SIMPSON, 2003, p.154)

Em 1980 começou a surgir uma nova geração de LEDs, melhorando sua qualidade de rendimento. Esse novo LED produz luz em uma gama de 590-630mu (âmbar-vermelho) tendo como base química o fosfato de alumínio de gálio-índio. Nesse momento surgia também o LEDs azul com bases químicas de carboneto de silício. Apesar de os LEDs da faixa vermelha do espectro já estarem bem supridos por dispositivos de alta eficiência, o verde e o azul se apresentavam deficientes. Isso porque, explica Simpson 
(2003, p.154-155), os verdes que existiam eram ineficientes e muito amarelos, já os azuis não serviam como fonte luminosa servindo apenas como "indicador". Em 1993, segundo nos relata o autor, foi anunciado o desenvolvimento de um LED azul com base química de nitreto de gálio que alcançava a gama de comprimento de onda entre 450$525 \mathrm{~m} \mu$ (azul-verde). A partir daí os LEDs podiam ser utilizados como fontes luminosas para diversas aplicações.

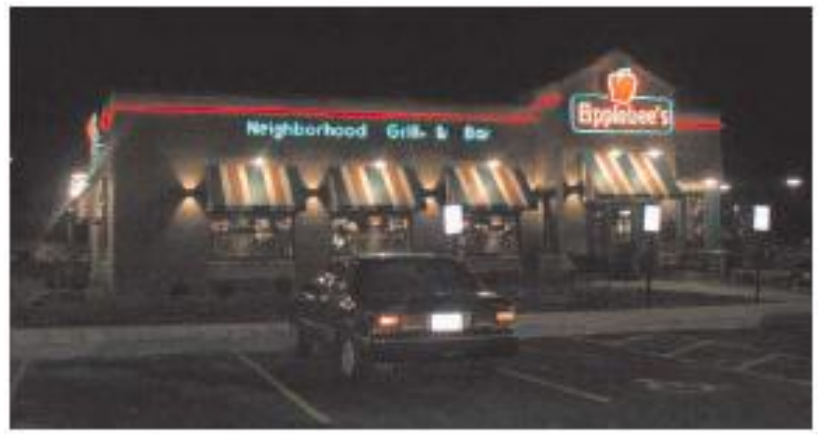

Figura 95: Nesta fachada os LEDs tiveram a mesma performance de uma luz neon quando agrupados lado a lado e internos a um tubo plástico.

Fonte: (SIMPSON, 2003, p.155)

Os LEDs são, individualmente, dispositivos de baixa potência e que, de acordo com Simpson (2003, p.155), operam em uma faixa de tensão de 1.5 até $4 \mathrm{~V}$, operando também em correntes mais altas como 100mA.

O grande valor do LED baseia-se em sua propriedade de alta luminosidade e longa vida. Os LEDs normalmente incorporam em sua estrutura, conforme Simpson (2003, p.155), lentes que têm o papel de espalhar a luz e podem ser definidos nos seguintes termos: Pico de luminosidade; Ângulo de visão cônica; Comprimento de onda dominante $626 \mathrm{~m} \mu$ vermelho, $615 \mathrm{~m} \mu$ vermelho alaranjado, $605 \mathrm{~m} \mu$ laranja, $590 \mathrm{~m} \mu$ âmbar, $525 \mathrm{~m} \mu$ verde, $505 \mathrm{~m} \mu$ azul esverdeado e $470 \mathrm{~m} \mu$ azul; Largura de faixa espectral de meia potência - normalmente, o intervalo de cores vermelhas nos LEDs tem uma largura de faixa espectral de meia potência próxima a $15 \mathrm{~m} \mu$, e nos azuis um intervalo de $30 \mathrm{~m} \mu$.

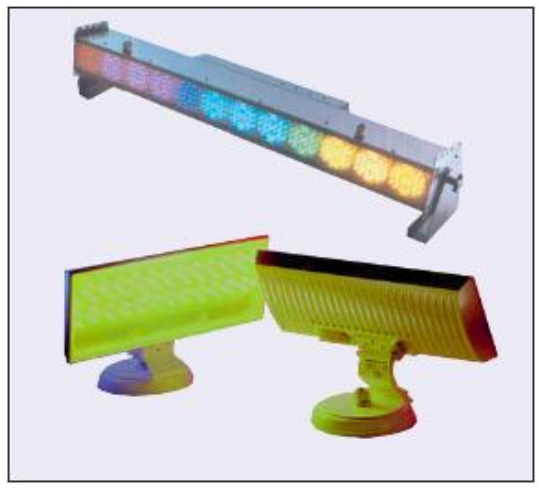

Figura 96: Iluminação colorida por meio da mistura de três cores de LED.

Fonte: (SIMPSON, 2003, p.156) 
A produção dos LEDs engloba uma diversidade de características em sua estrutura, podendo ser encontrados em diversos formatos. A vida útil do LED pode, de acordo com Simpson (2003, p.156), chegar a uma faixa de 50 até 100 mil horas, podendo ser afetada se exposta a altas temperaturas.

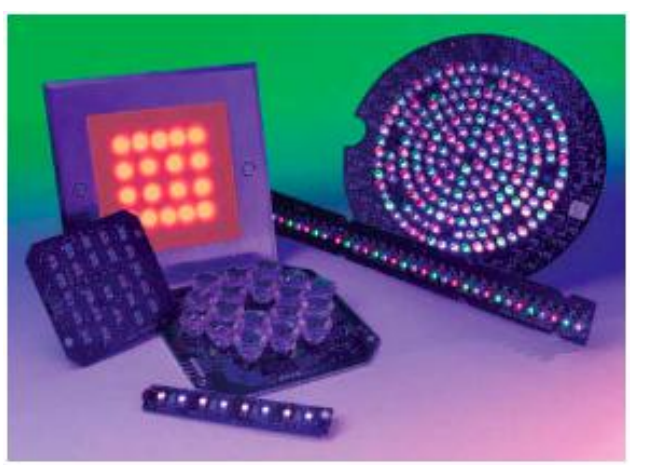

Figura 97: Diversos modelos estruturais onde os LEDs podem ser aplicados. Fonte: (SIMPSON, 2003, p.156)

Nas obras produzidas nas Novas Tecnologias da Comunicação (NTC) são comumente utilizados para se trabalhar com cores em ambientes escuros devido à sua alta luminosidade. É bastante comum a utilização de LEDs de três cores - vermelho, verde e azul - próximos, de forma a, unidos, representarem uma única cor do espectro por meio de mistura aditiva.

Quando a cor necessária na representação não está disponível nas cores básicas de LED, o que se costuma fazer é trabalhar com a mistura aditiva posicionando as três cores básicas $($ vermelho $=626 \mathrm{~m} \mu$, verde $=525$ e azul $=470)$ lado a lado, propiciando a obtenção de qualquer cor do espectro. E assim como a união de diferentes intensidades dessas três cores pode formar uma cor específica, se todas elas estiverem vibrando na máxima intensidade obteremos a luz branca. Mas pelo fato de essa alternativa, em alguns casos, não ser muito prática para a produção de luminárias de luz branca, foi desenvolvido, de acordo com Simpson (2003, p.156), o LED branco, um dispositivo híbrido que utiliza a fotoluminescência. O único problema do LED branco é sua vida útil, que não chega a dez mil horas. 


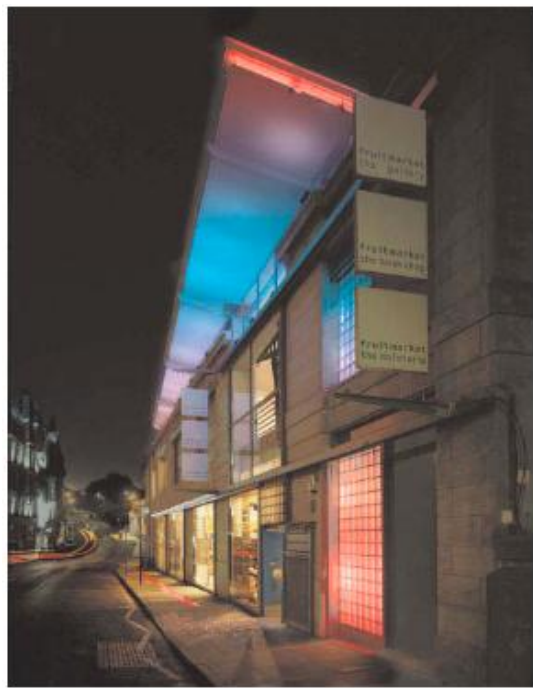

Figura 98: Fachada que utiliza os LEDs como dispositivo para iluminação. Fruitmarket Gallery, Edinburgh. Fonte: (SIMPSON, 2003, p.157)

O uso mais comum para o LED é em telas de exibição. Os LEDs, além de poder emitir diferentes cores, assim como vermelho, verde, amarelo, laranja e branco, pode também, segundo Cheruku e Krishna (2008, p.85), operar no modo infravermelho, ficando assim fora das radiações visíveis pelo olho humano.

De acordo com Shur (1996, p.478), LEDs são utilizados em displays, ligações de comunicação por fibra óptica, computadores digitais, painéis eletrônicos, comunicações ópticas e assim por diante. Recentemente displays eletroluminescentes, segundo Shur (1996, p.478), foram substituídos por LCDs.

\section{Cabos de Fibra Óptica}

A fibra óptica não é um tipo de fonte luminosa, mas ele transporta a luz para onde é necessário, controlando a sua saída. Seu princípio, segundo Simpson (2003, p.166), depende totalmente da reflexão interna de luz decorrente do uso de dois materiais com diferentes índices de refração. $\mathrm{O}$ autor esclarece que a fibra óptica consiste de um núcleo rodeado por um revestimento de menor índice de refração. 


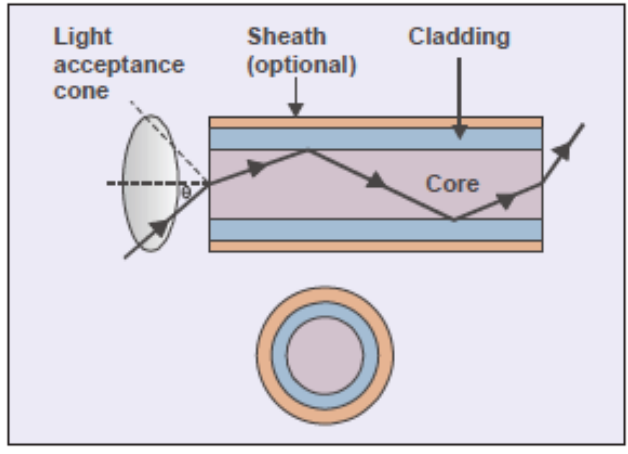

Figura 99: Ilustração que apresenta os princípios da fibra óptica. Fonte: (SIMPSON, 2003, p.166)

Para a luz entrar em contato com a fibra óptica é necessário direcioná-la a uma das extremidades da fibra, cujo ângulo de aceitação é determinado pelo índice de refração do núcleo e do revestimento, conforme nos elucida Simpson (2003, p.166).

A fibra óptica, cuja função é iluminar, é feita a partir do vidro ou de polímeros plásticos assim como o polimetil-metacrilato (PMMA). As fibras com feixes de vidro são finas, com $1 \mathrm{~mm}$ de diâmetro, possuem longa durabilidade, são precisas mas caras. As fibras de plástico são mais grossas, podendo alcançar $18 \mathrm{~mm}$ de diâmetro, sua qualidade não é tão superior como as fibras de vidro, podendo não obter uma boa performance em algumas aplicações. Sua duração é de dez a quinze anos, não sendo indicada para uso interno.

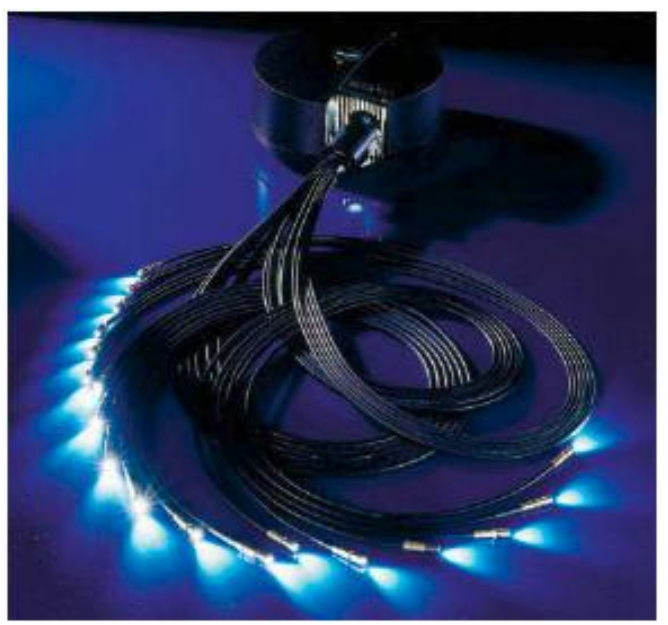

Figura 100: Fibra óptica

Fonte: (SIMPSON, 2003, p.167)

A performance de uma fibra óptica pode ser medida, segundo Simpson (2003, p.167), por uma série de fatores como: Atenuação - sobre um dado comprimento; Resposta espectral - se há variação de cor na entrada e saída; Capacidade de flexão - fibras mais finas são mais indicadas para um curto raio de curvatura; Uniformidade. 
Um sistema de iluminação com fibra óptica consiste, conforme Simpson (2003, p.168), de três componentes principais. Um feixe de fibras ópticas, um iluminador e saídas ópticas. Um círculo de cores pode ser usado como um acessório componente.

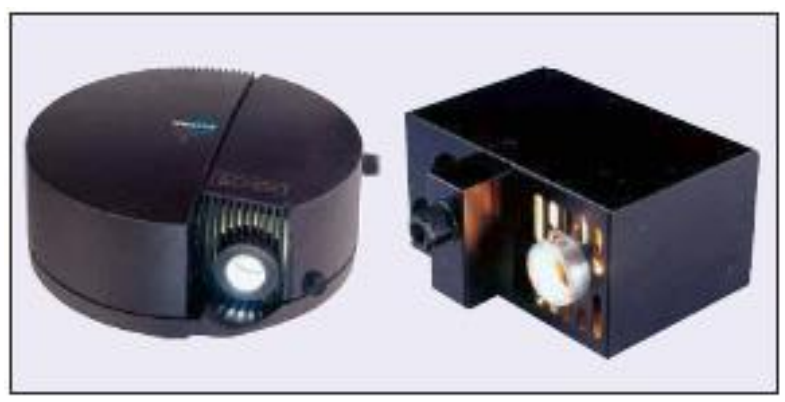

Figura 101: Exemplo de iluminadores.

Fonte: (SIMPSON, 2003, p.168)

Existem vários tipos de saídas ópticas. São normalmente utilizadas em sistemas mais sofisticados de exposição, onde a saída de um feixe de fibras é acoplado a uma pequena "luminária", que executa a função de spotlight e holofote, usualmente com a ajuda de uma lente adicional.

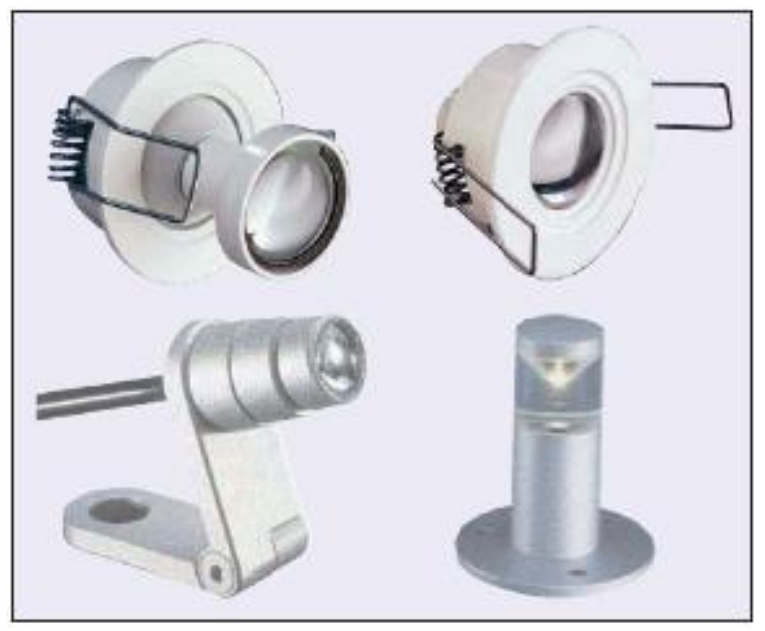

Figura 102: Modelos de saídas ópticas. Fonte: (SIMPSON, 2003, p.168)

A eficácia no sistema de iluminação de uma fibra óptica é baixa. Mas esse sistema possui vantagens para algumas aplicações, as quais Simpson (2003, p.169) nos lista:

- Ideal para locais úmidos e perigosos. [...] A luz não tem qualquer ligação eléctrica.

- A luz de saída é isenta de IR e UV (mas para alguns filtros de fibras são necessários no momento da entrada para evitar danos à própria fibra).

- De fácil manutenção para vários pontos de luz. Em vez de ter que mudar 50 ou 1.000 lâmpadas em uma vitrine, é necessário trocar apenas uma. 
- Vantagens para algumas aplicações estéticas, decorrentes da ausência de luminárias volumosas. Juntamente com isso está a capacidade de obter uma fonte de iluminação em uma posição que seria completamente impraticável com uma luminária convencional. SIMPSON (2003, p.169)

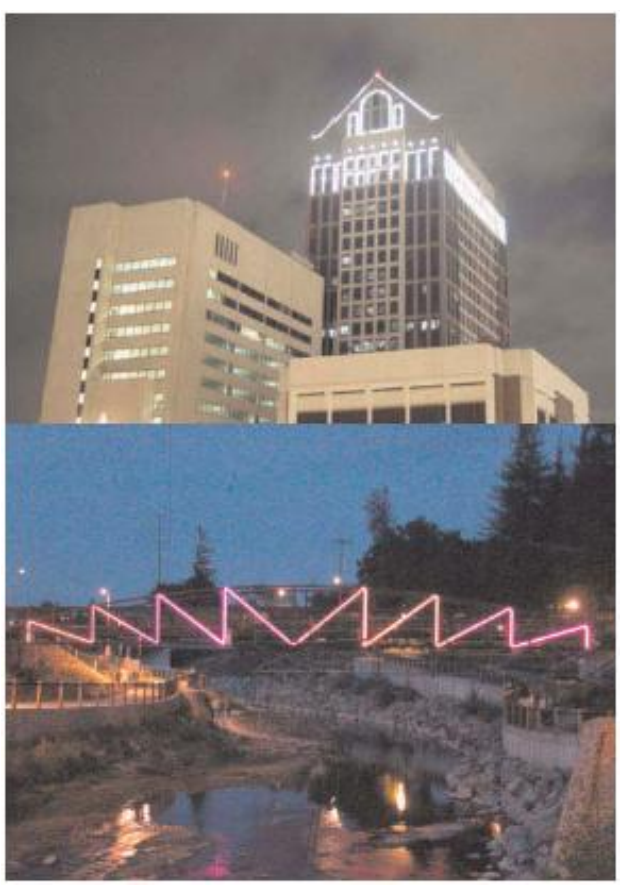

Figura 103: Iluminação feita por um sistema de luzes ópticas.

Fonte: (SIMPSON, 2003, p.169)

A aplicação deste tipo de iluminação varia desde a área de entretenimento e apresentação, passando por sinalização de piscinas e fontes até a iluminação em museus, galerias e shows.

\section{Projetor de vídeo como fonte de iluminação}

Existem outras fontes de luz geradas por meio elétrico além das lâmpadas. Quem faz menção delas é Simpson (2003, p.171) ao lembrar dos tubos de raios catódicos (CRT) que serviram como fonte de luz nas casas durante 60 anos (apesar de essa não ser sua principal função). De acordo com o autor, a superfície brilhante de uma CRT, e agora nos tempos atuais de outros tipos de telas, como LCD e plasma, é bastante significante, pois faz parte de um esquema de iluminação, mesmo se eles estão mostrando imagens de vídeo normais ou apresentando cores como um efeito. 


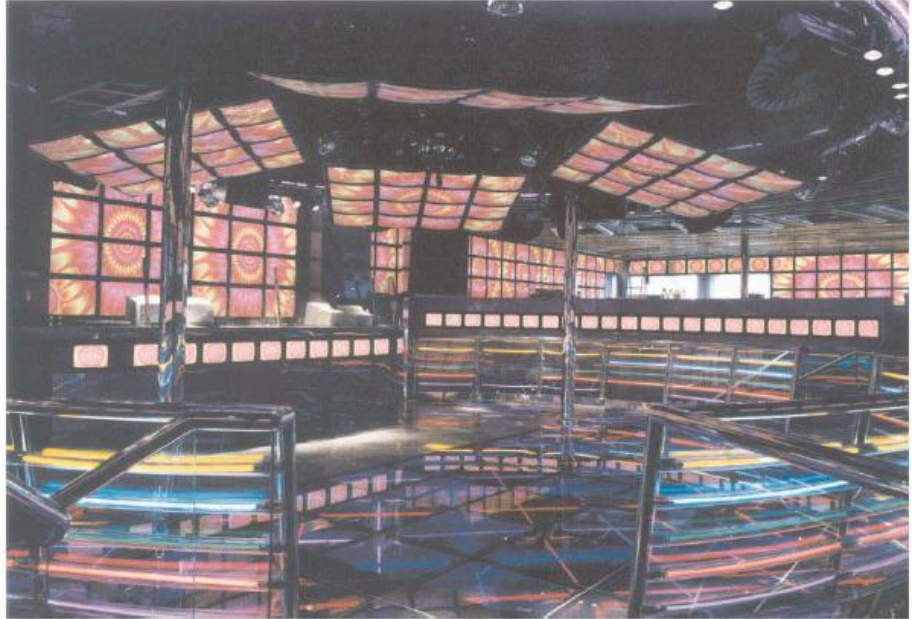

Figura 104: Telas de CRT utilizadas como principal fonte luminosa em uma danceteria.

Fonte: (SIMPSON, 2003, p.171)

\section{Tubo de Raios Catódicos (CRT)}

Um CRT é, conforme Shur (1996, p.493), é um tubo a vácuo com um catodo que emite um feixe de elétrons acelerados pela diferença entre a voltagem do anodo e do catodo. O sistema de deflexão direciona o feixe em qualquer posição na tela usando tanto o campo elétrico como o magnético.

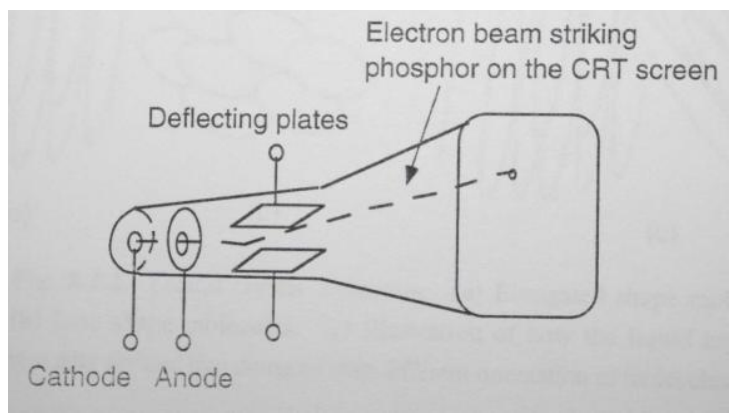

Figura 105: Diagrama esquemático de um CRT. Fonte: (SHUR, 1996, p.493)

Quando o feixe de elétrons atinge a superfície fosforescente, dá origem a um ponto (pixel) na tela emitindo luz. A intensidade da luz pode ser comandada ao se controlar a energia dos elétrons presentes no feixe (um exemplo seria alterando a voltagem do anodo).

Em um monitor colorido a tela é coberta com uma malha de pontos de fósforos que emitem as três cores primárias luminosas: vermelho, verde e azul. Dependendo da intensidade de cada uma dessas três cores primárias é possível representar qualquer matiz do espectro, como pudemos exemplificar com maior acuracidade no segundo capítulo desta pesquisa. A seguir podemos visualizar de perto os pontos RGB que estão presentes na tela de uma televisão. 


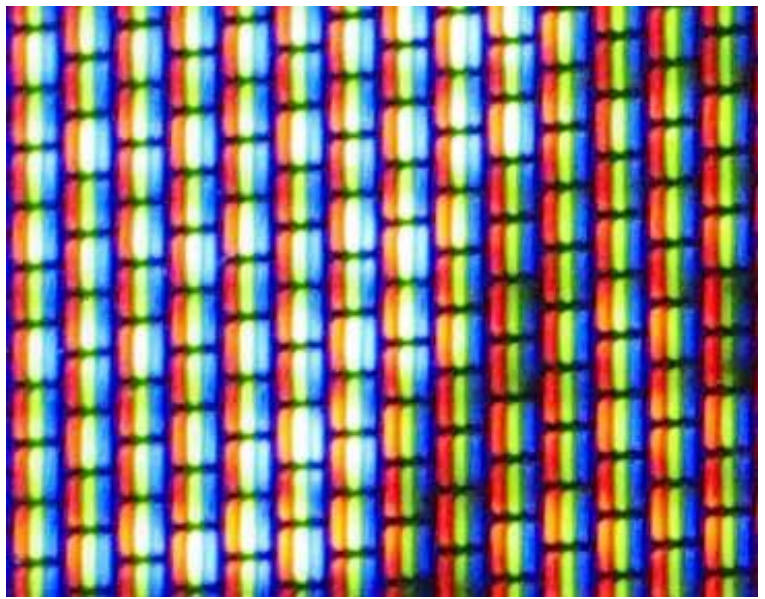

Figura 106: Vista aproximada da tela de um monitor CRT. Fonte: a própria autora

O conjunto dos três pontos de fósforo posicionados lado a lado vermelho, verde e azul formam um pixel colorido. O olho do observador irá perceber a soma de intensidade de cada uma das cores resultantes em um único pixel com uma matiz apenas. São necessários, conforme Shur (1996, p.493) nos afirma, três feixes de elétrons separados para ativar cada pixel colorido, e a cor da luz emitida dependerá da intensidade desses feixes.

A melhor qualidade das cores emitidas desses monitores acontece quando os tubos possuem, próximo a tela, uma máscara de metal perfurada (máscara de sombra) com uma malha de furos. Esse acessório, segundo nos relata Shur (1996, p.494), faz com que os três feixes de elétrons que passam pelo furo fiquem mais definidos, aumentando a qualidade da imagem final.

A imagem é formada nesse monitor pelo movimento dos feixes de elétrons horizontalmente da esquerda para a direita, uma linha após a outra. O número de linhas varia de acordo com a resolução do monitor. Um monitor de computador com alta qualidade pode ter, por exemplo, 768 linhas com 1.024 pixels em cada linha, totalizando 768.432 pixels.

Ainda conforme Shur (1996, p.494), o olho humano não percebe a tremulação da imagem se esta se altera a cada $30 \mathrm{~ms}$. (esse índice pode se alterar de pessoa para pessoa). 


\section{Telas de Cristal Líquido (LCD)}

Depois da era de domínio dos monitores CRT, surge em 1990 os monitores de cristal líquido. Segundo Travis (1991, p.23), a tecnologia de LCD era usada em mostradores de relógios digitais e até em televisores portáteis. Essa tecnologia tem propriedades de líquido e de cristal, de forma que o líquido permite o escoamento e o cristal permite a retenção, assim a estrutura molecular típica de cristais é organizada.

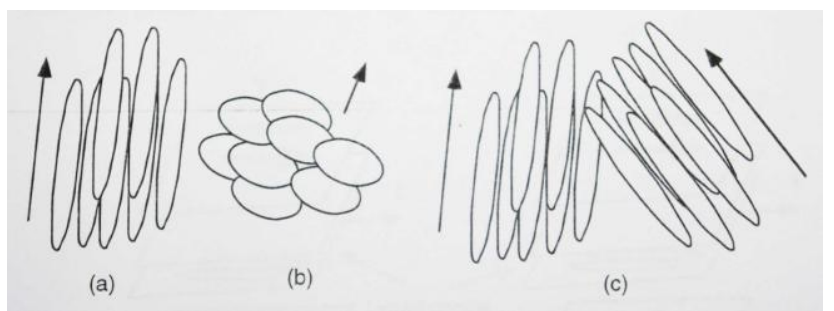

Figura 107: Moléculas de cristal líquido.

Fonte: (SHUR, 1996, p.495)

Se tomarmos como base o líquido formado por essas moléculas, segundo Shur(1996, p.249) o líquido passa a se chamar cristal líquido, possuindo propriedades anisotrópicas. Normalmente o cristal líquido com moléculas orientadas em uma direção é chamado de cristal líquido nemático. O cristal líquido é normalmente dividido em domínios com diferentes orientações de moléculas. Para que as moléculas assumam apenas uma direção o autor recomenda o uso de duas lâminas de vidro polido em uma direção, um por cima e outro por baixo do cristal líquido nemático.

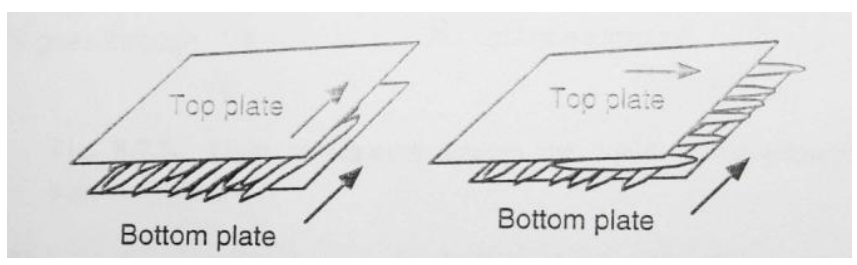

Figura 108: Orientação esquemática das moléculas em líquido nemático entre duas lâminas de vidro.

A seta representa a orientação de polimento das lâminas.

Fonte: (SHUR, 1996, p.495)

A distância entre os vidros de um monitor comum que use cristal líquido é, segundo Shur (1996, p.495), de vários microns. Quando a luz atinge o cristal líquido a interação do campo elétrico das ondas eletromagnéticas junto com as moléculas alongadas depende fortemente do campo elétrico.

Os displays LCD podem utilizar a luz refletida ou possuir uma luz fluorescente. Os pixels nas telas mais simples podem ser pretos ou brancos, dependendo do sinal aplicado. Telas mais sofisticadas possuem vários tons de cinza. E se três pixels 
próximos um do outro forem cobertos por filtros de cores vermelho, verde e azul formando um pixel, o LCD se torna colorido.

\section{Sensores de luz e presença}

Quando se trabalha com o uso da luz de maneira automatizada, é necessário agregar sensores ao sistema de controle de luz. O mais comum no caso das instalações artísticas são sensores que detectam a presença humana e a luz. Leva-se em conta, portanto, a necessidade de se detectar o posicionamento de um indivíduo em um dado momento, por isso a utilização desses equipamentos.

De acordo com Simpson (2003, p.405), microinterruptores formam a base dos mais simples mecanismos de um sensor. Trata-se de um interruptor que utiliza um contato biestável que se aciona automaticamente. $O$ acionamento do sensor pelo microinterruptor se dá pela detecção do elemento.

A maioria dos sensores de luz utilizados em controle luminoso, segundo Simpson (2003, p.407), usa silicon photo-diode em modo fotovoltaico em conjunto com um amplificador, promovendo assim uma saída proporcional ou um sinal para o funcionamento de um relé.

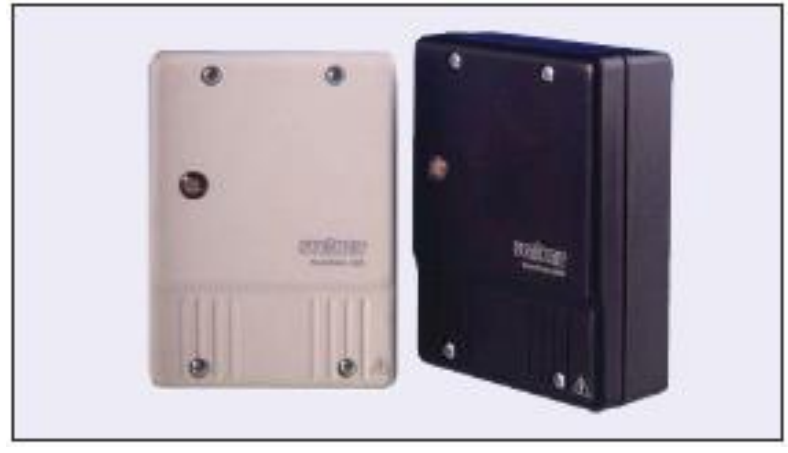

Figura 109: Sensores sensíveis à luz. Fonte: (SIMPSON, 2003, p.407)

Muitas aplicações utilizam apenas de simples sensores de luz onde o fotodiodo controla o relé. Segundo Simpson (2003, p.407), um simples ajuste define o nível de iluminação necessário para a operação.

Os sensores de presença mais comuns utilizados para controlar a iluminação são os detectores de feixe e os detectores passivos. 
Detectores de feixes são fotoelétricos. Neles, um feixe infravermelho (fora do nosso campo de visão), quando "quebrado" pela presença humana, aciona o detector. O feixe infravermelho é, segundo Simpson (2003, p.408), gerado por um LED, e sua detecção é feita pelos silicon photodiodes, que são altamente sensíveis à luz infravermelha.

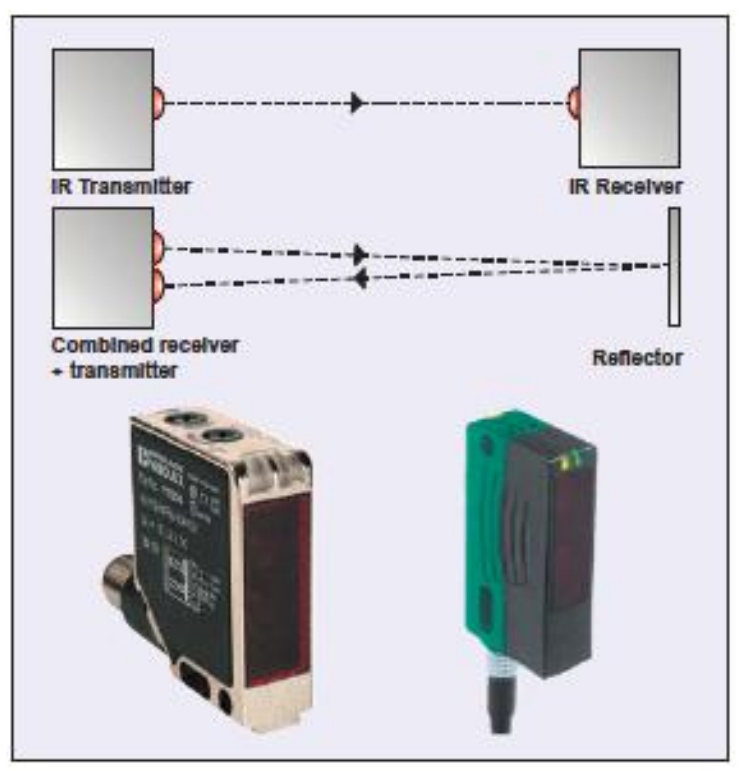

Figura 110: Príncipio de funcionamento dos sensores de feixe. Fonte: (SIMPSON, 2003, p.408)

Os detectores de feixe podem operar em longas distâncias. Quando em área externa podem alcançar até 100 metros, e nas áreas internas pode variar de 10 a 20m, conforme descrição de Simpson (2003, p.408). A melhor utilidade para este tipo de sensor é indicar a presença de uma pessoa. Quando envolve um grande número de pessoas, o detector mais indicado seria o sensor infravermelho passivo.

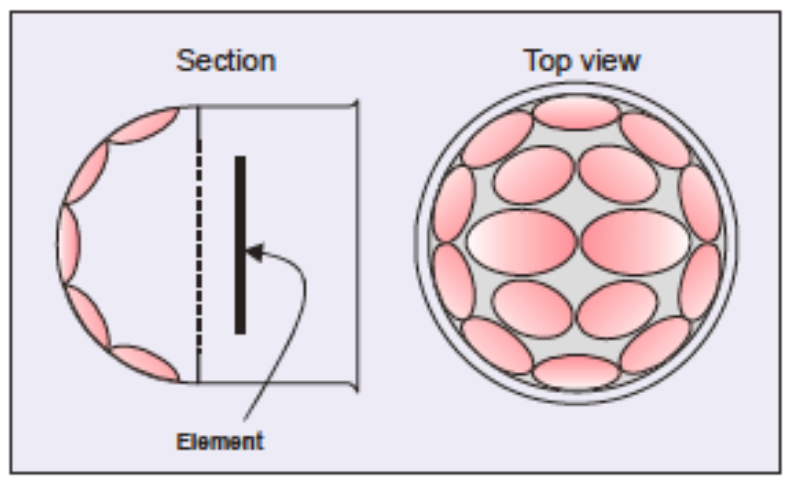

Figura 112: Arranjo de lentes típico de um sensor PIR.

Fonte: (SIMPSON, 2003, p.408) 
O sensor infravermelho passivo (PIR) se baseia em um complexo sistema de múltiplos feixes e é recomendado para espaços maiores. Esse dispositivo, conforme Simpson (2003, p.408), funciona de acordo com um princípio pyrometric, que mede o calor. O princípio do PIR é captar a total emanação de calor do ambiente monitorado. Se o sensor percebe que um elemento parado e que produz calor permanece sempre parado, $o$ detector não emite nenhum sinal, mas se existe a presença de qualquer outro elemento maior que um determinado tamanho movendo-se na área, o dispositivo detecta seu calor e produz um sinal de saída.

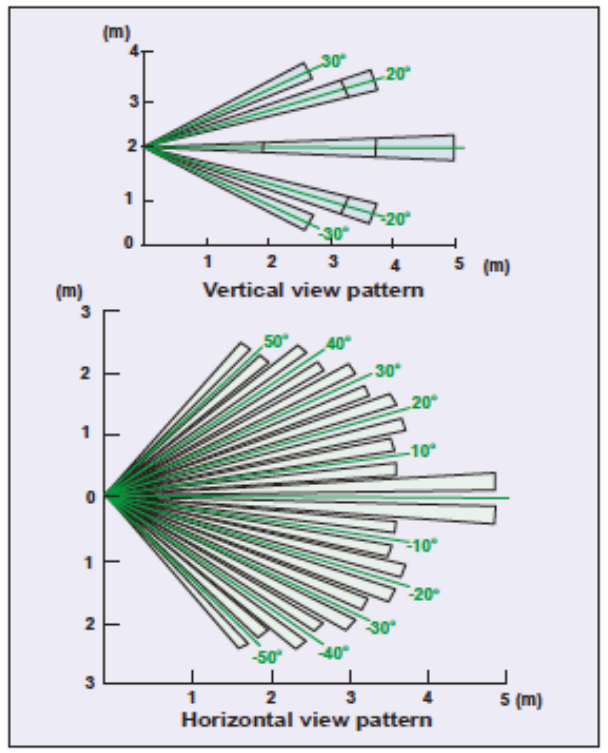

Figura 113: Diagrama da área de detecção de um PIR apresentando a configuração comum dos feixes correspondentes às 16 lentes presentes no sensor. Fonte: (SIMPSON, 2003, p.409)

Sensores PIR e de feixes infravermelhos são feitos exclusivamente para detectar a presença humana. Existem outros tipos de sensores de presença, como os ultrassônicos e de micro-ondas.

Os sensores ultrassônicos, segundo Simpson (2003, p.410), utilizam o efeito doppler para detecção de fontes móveis de som. Nesse caso, se uma pessoa se move em uma área repleta de ondas ultrassônicas (ondas de som cuja frequência é inaudível ao ser humano) suas reflexões podem ser detectadas como sendo de diferentes frequências. 


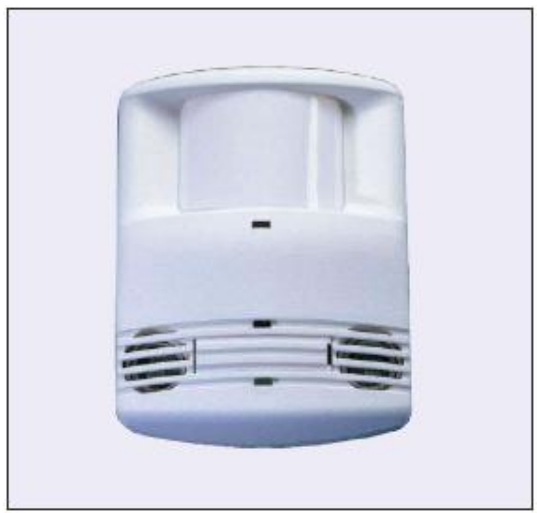

Figura 114: Sensor que combina detecção ultrasonica e PIR.

Fonte: (SIMPSON, 2003, p.410)

Os sensores de micro-ondas também utilizam o efeito doppler, mas em conjunto com radiações eletromagnéticas de micro-ondas. São normalmente utilizados como dispositivos de segurança em locais bastante iluminados. 